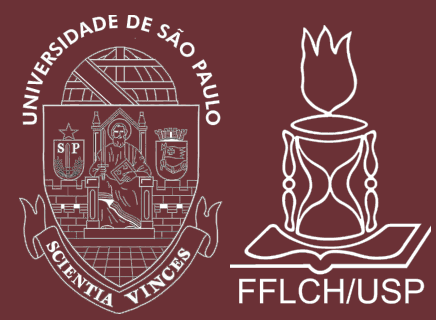

André Pasti

\title{
Mídia, território e comunicação ascendente: \\ Políticas e disputas para a democratização da comunicação na Argentina
}

São Paulo 2018 
André Pasti

\section{Mídia, território e comunicação ascendente: \\ Políticas e disputas para a democratização da comunicação na Argentina}

Versão corrigida

Orientadora: Profa ${ }^{\text {. Dra }}{ }^{\text {. Mónica Arroyo }}$

Tese apresentada ao Departamento de Geografia da Faculdade de Filosofia Letras e Ciências Humanas da Universidade de São Paulo para obtenção do título de Doutor em Geografia.

Área de Concentração: Geografia Humana

São Paulo 


\section{通fflch}

\section{ENTREGA DO EXEMPLAR CORRIGIDO DA TESE}

Termo de Ciência e Concordância da orientadora

Nome do aluno: André Buonani Pasti

Data da defesa: 01/11/2018

Nome da profa . orientadora: María Mónica Arroyo

Nos termos da legislação vigente, declaro ESTAR CIENTE do conteúdo deste EXEMPLAR CORRIGIDO elaborado em atenção às sugestões dos membros da comissão Julgadora na sessão de defesa do trabalho, manifestando-me plenamente favorável ao seu encaminhamento e publicação no Portal Digital de Teses da USP.

São Paulo, $19,12,2018$

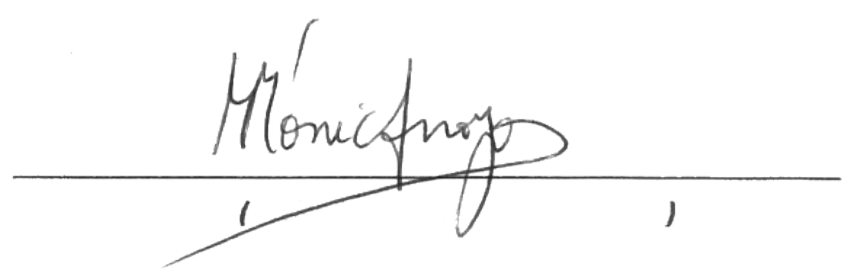


Autorizo a reprodução e divulgação total ou parcial deste trabalho, por qualquer meio convencional ou eletrônico, para fins de estudo e pesquisa, desde que citada a fonte.

Faculdade de Filosofia, Letras e Ciências Humanas da Universidade de São Paulo

Pasti, André

Mídia, território e comunicação ascendente:

Políticas e disputas para a democratização da

comunicação na Argentina / André Pasti ; orientadora

Mónica Arroyo. - São Paulo, 2018.

$305 \mathrm{f}$.

Tese (Doutorado)- Faculdade de Filosofia, Letras e Ciências Humanas da Universidade de São Paulo. Departamento de Geografia. Área de concentração: Geografia Humana.

1. Território. 2. Comunicação. 3. Argentina. 4. Geografia -- Argentina. 5. Democratização da comunicação. I. Arroyo, Mónica, orient. II. Título. 
PASTI, André. Mídia, território e comunicação ascendente: Políticas e disputas para a democratização da comunicação na Argentina. Tese apresentada à Faculdade de Filosofia, Letras e Ciências Humanas da Universidade de São Paulo para obtenção do título de Doutor em Geografia.

Aprovado em: 01 de novembro de 2018.

\section{Banca Examinadora}

Prof. Dr. Martín Becerra

Universidad Nacional de Quilmes (Argentina)

Profa. Dra. Perla Zusman

Universidad de Buenos Aires (Argentina)

Prof. Dr. Rodrigo Valverde

Universidade de São Paulo 
à memória do amigo e grande geógrafo Fernando Antonio da Silva (1991-2018), cuja perda é muito sentida. 


\section{Agradecimentos}

O trabalho de pesquisa sempre envolve trocas e processos coletivos. Sabendo da impossibilidade de nomear todos os envolvidos, deixo aqui um agradecimento amplo aos que contribuíram, direta ou indiretamente, com esta tese. Especialmente, agradeço à Mónica Arroyo, pela amizade e pela orientação espetacular que carrega os méritos deste trabalho - uma honra e uma alegria ter tido a possibilidade de compartilhar esse processo e aprender tanto sob sua orientação; a Perla Zusman e Rodrigo Valverde, pelas estimadíssimas contribuições no exame de qualificação; a ambos e também ao Martín Becerra agradeço pelas tão valiosas trocas e reflexões na defesa da tese; à Perla e também ao Héctor Poggiese agradeço, ainda, pela recepção e apoio fundamentais na Argentina, pelos diálogos tão valorosos e pelas portas abertas.

Aos entrevistados, comunicadores e pessoas com quem pude dialogar e aprender ao longo desses anos, meus mais sinceros agradecimentos. Muito obrigado também aos amigos, docentes, colegas e trabalhadores da FFLCH, do Instituto de Geografia da UBA, da FLACSO-Argentina e do Cotuca/Unicamp. Muitíssimo obrigado aos amigos do grupo de pesquisa, do Laboplan, e da pósgraduação - da USP, Unicamp, Unesp e UBA.

Registro ainda, em especial, o agradecimento à Taís, por compartilhar a vida de forma tão incrível, pelo amor cotidiano e apoio incondicional; a meu irmão e toda a minha família (agora expandida), pelo apoio e sustentação permanente; à Isadora, amiga imprescindível e definição de parceria, com quem aprendo sempre; a Luciano, Melissa e Wagner, pela amizade e cooperação tão fundamentais ao longo de todo esse processo, assim como a Paulinha e Rocha, essenciais e sempre presentes.

O desenvolvimento dessa pesquisa - tratando de um território que não o brasileiro - só foi possível graças ao financiamento público, pelo Conselho Nacional de Desenvolvimento Científico e Tecnológico (CNPq), por meio da Bolsa de Doutorado e da Coordenação de Aperfeiçoamento de Pessoal de Nível Superior (CAPES), pela Bolsa de Doutorado Sanduíche que possibilitou estágio 
de pesquisas na Argentina. Agradeço a essas instituições e a todas as pessoas que lutaram e lutam para o desenvolvimento da ciência e tecnologia públicas no Brasil e na América Latina.

À Virna e Villy, pela amizade e delicada acolhida em Buenos Aires. Também pela acolhida, agradeço profundamente a Mariana e Hernán, em Misiones, Malala, em Paraná, María Fernanda, em Quito, e Gustavo, em Montevidéu. Em Buenos Aires, agradeço especialmente Sita, Verónica, Fer, Tania, Dante, Ernesto e Marina pela recepção e interlocuções - estendendo um forte abraço a todos os amigos portenhos. Muitíssimo obrigado María Laura Silveira e todo o seu grupo, pelas trocas tão enriquecedoras à tese.

Aos docentes e colegas dos cursos da pós na FFLCH, no PROLAM e no IDES, sou grato pelos intercâmbios de ideias. Igualmente agradeço pelas contribuições de Agustín Espada, Fabrício Gallo, Rogério Bezerra, Pedro Aguiar e dos integrantes do sempre proveitoso e prazeroso diálogo do GP Geografias da Comunicação da Intercom, dos participantes do Colóquio Argentina-Brasil de Comunicação e da Rede Latino-Americana de Participação Popular em Políticas Públicas. Aos docentes do Departamento de Geografia da FFLCH/USP e do IG/Unicamp, muito obrigado.

Sem nomear cada um - pois são muitas as contribuições cotidianas nesses quatro anos - agradeço aos muitos e queridos amigos, como os sempre especiais do Contra, do Cotuca, da graduação, do ativismo, da docência e de tantos encontros cotidianos que nutrem e com quem compartilhamos alegrias, debates e utopias. Aos companheiros da luta pelo direito à cidade, do FNRU, da AGB e da Adunicamp, muito obrigado! Agradeço, sempre, aos meus alunos e alunas, que permitem que eu aprenda tanto - em especial aos orientandos com quem pude conviver e trocar intensamente nos últimos anos.

Agradeço, também, a todas e todos os grandes amigos e companheiros de luta do Intervozes e do movimento pela democratização da comunicação nos diferentes países da América Latina, por me ensinarem tanto e por compartilharem as ações de construção de outro futuro. 
O homem moderno é, talvez, mais desamparado que os seus antepassados, pelo fato de viver em uma sociedade informacional que, entretanto, lhe recusa o direito a se informar.

Milton Santos, O espaço do cidadão (2007).

Comunicação é a coparticipação dos Sujeitos no ato de conhecer, ela implica numa reciprocidade que não pode ser rompida. Comunicação é diálogo na medida em que não é transferência de saber, mas um encontro de Sujeitos interlocutores que buscam a significação dos significados.

Paulo Freire, Extensão ou Comunicação (2011), adaptado por Lima (2011a). 


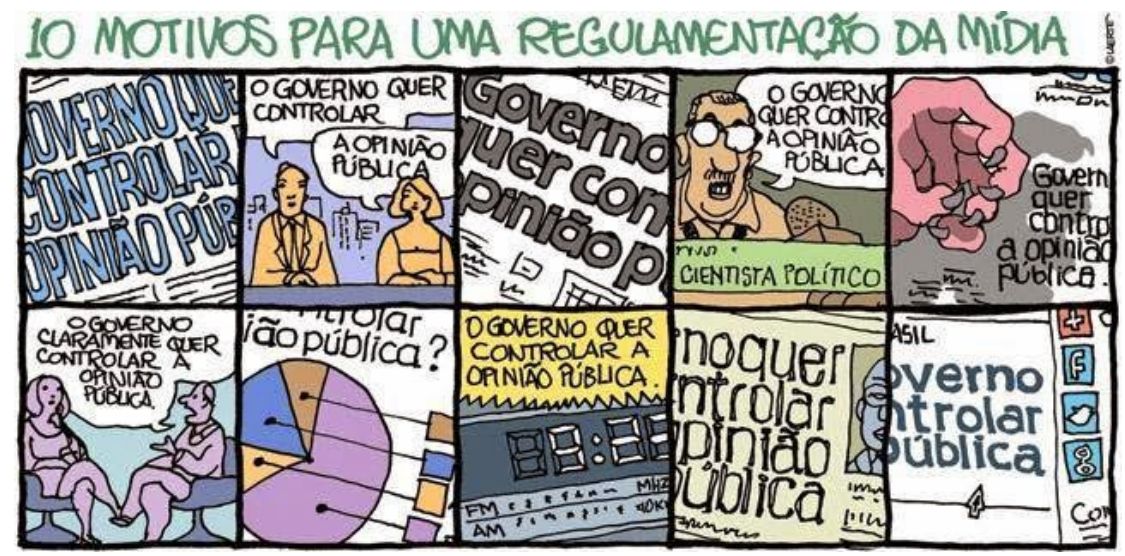

Tirinha da Laerte. 


\section{Mídia, território e comunicação ascendente: políticas e disputas para a democratização da comunicação na Argentina}

\section{Resumo}

A partir de demandas de movimentos sociais gestadas durante décadas, a Argentina aprovou, em 2009, uma Lei de Serviços de Comunicação Audiovisual (n. 26.522, conhecida como "Ley de Medios"), baseada no paradigma da comunicação como um direito, promovendo o combate à concentração na mídia e a promoção da pluralidade e diversidade na comunicação. Entendendo esse processo como um evento geográfico, a presente pesquisa analisa o sentido das principais transformações na organização da comunicação no território argentino a partir dessas políticas de comunicação. $\mathrm{Na}$ perspectiva da democratização da comunicação, as novas condições normativas foram aliadas a disputas de sentidos na psicosfera e ao impulsionamento de transformações na tecnosfera, reorganizando as redes técnicas de suporte ao funcionamento da comunicação. Dando ênfase às políticas que apontavam para a promoção de maior densidade comunicacional e ampliação da comunicação ascendente, baseada no cotidiano e nas trocas a partir dos lugares, destacam-se: o programa Polos Audiovisuais Tecnológicos, que buscava regionalizar a produção audiovisual a partir de uma rede federal de Nós Audiovisuais fundados em processos participativos, com gestão associada da sociedade com o Estado; e as ações para o reconhecimento e fomento de meios comunitários, populares e alternativos. Por fim, a partir do início da gestão presidencial de Mauricio Macri, em dezembro de 2015, há uma reorientação das políticas de comunicação e um desmonte do marco normativo e institucional na Lei de Serviços de Comunicação Audiovisual, sob o paradigma da comunicação como negócio.

Palavras-chave: Território, Comunicação, Argentina, Políticas de comunicação, Democratização da comunicação. 


\title{
Media, territory and ascending communication: policies and disputes for the democratization of communication in Argentina
}

\begin{abstract}
In 2009, Argentina approved an Audiovisual Communication Services Law (No. 26,522, well known as the "Ley de Medios") based on demands from social movements developed for decades. The paradigm was the Right to Communicate, promoting plurality and diversity and fighting the media monopoly. The present research analyzes this process as a geographical event. Through the study of these communication policies, we have addressed the reorganization of communication in the territory of Argentina. We may state that the new normative conditions were allied to disputes of meanings on the psychosphere and to the impulse of changes on the technosphere. The emphasis was on the policies that aimed to promote communication density and the ascending communication. There were two highlights: a national program for the development of audiovisual centers within the country, which promoted regionalized audiovisual production from a federal network based on participatory processes; and the actions for the recognition and funding of community, popular and alternative media outlets. In December 2015, the beginning of the presidential administration of Mauricio Macri changed the paradigm of communication policies, based on the defense of business interests. The normative and institutional framework of the Audiovisual Communication Services Law was then dismantled.
\end{abstract}

Keywords: Territory, Communication, Argentina, Communication policies, Democratization of communication. 


\section{Medios, territorio y comunicación ascendente: políticas y disputas para la democratización de la comunicación en Argentina}

\section{Resumen}

En Argentina, a partir de demandas de movimientos sociales gestadas durante décadas, una Ley de Servicios de Comunicación Audiovisual (26.522, conocida como Ley de Medios) fue aprobada en 2009. La ley estuvo basada en el paradigma de la comunicación como un derecho, promoviendo la pluralidad y la diversidad y luchando contra el monopolio de los medios de comunicación. Las nuevas condiciones normativas se aliaron a disputas de significados sobre la psicosfera y al impulso de cambios en la tecnosfera. La investigación enfatizó las políticas que tenían como objetivo promover la densidad de comunicación en los lugares y la comunicación ascendente. Se destacaron dos aspectos: un programa nacional para el desarrollo de centros audiovisuales en el país, Polos Audiovisuales Tecnológicos, que promovió la producción audiovisual regionalizada de una red federal basada en procesos participativos; y las acciones para el reconocimiento y financiamiento de medios comunitarios, populares y alternativos. En diciembre de 2015, el inicio de la administración presidencial de Mauricio Macri cambió la orientación de las políticas de comunicación, basado en la defensa de los intereses comerciales de los conglomerados de medios. El marco normativo e institucional de la Ley de Servicios de Comunicación Audiovisual fue luego desmantelado, bajo el paradigma de la comunicación como negocio.

Palabras clave: Territorio, Comunicación, Argentina, Políticas de comunicación, Democratización de la comunicación. 


\section{Lista de figuras}

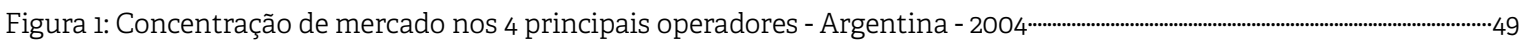

Figura 2: Concentração de mercado nos 4 principais operadores - Argentina - 2008 ………….....................................................................................50

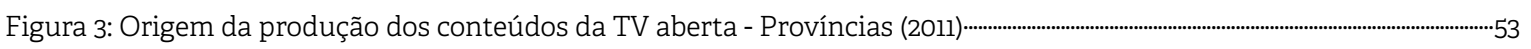

Figura 4: Origem da produção de conteúdos da TV aberta - região metropolitana de Buenos Aires (2011)..........................................53

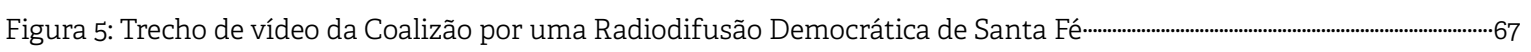

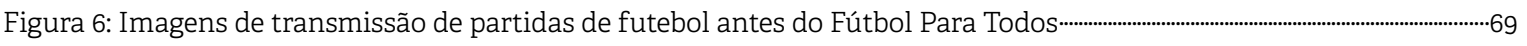

Figura 7: Cartaz chamando a um ato em defesa da aprovação da Lei de Serviços de Comunicação Audiovisual, no Dia da

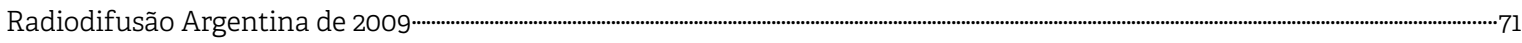

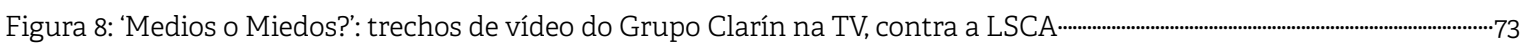

Figura 9: 'Clarín en el mercado argentino’: trechos de vídeo do Grupo Clarín, rebatendo críticas da concentração da

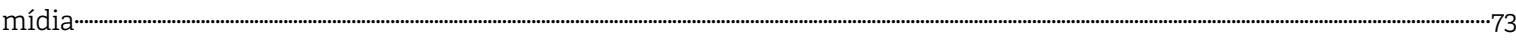

Figura 10: ‘Ley de medios: articulos denunciados por inconstitucionales': vídeo veiculado pelo Grupo Clarín questionando judicialmente a LSCA.

Figura 11: 'Aviso sobre la plena vigencia de la Ley de Medios (LSCA) a partir del 7 de diciembre': vídeo da autoridade de aplicação da LSCA para o 7D-...

Figura 12: 'Ley de Medios, Una ley para que hablemos todos': trechos de vídeo em defesa da Lei de Meios, elaborada no conurbano de Buenos Aires.

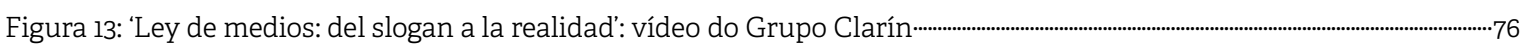

Figura 14: Penetração de banda larga fixa no território argentino - estimativa de percentual de habitantes com acesso

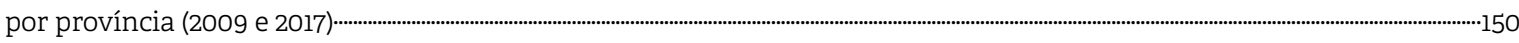

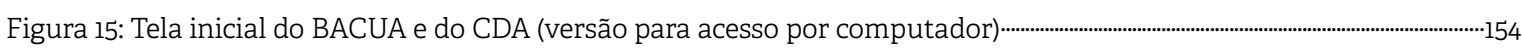

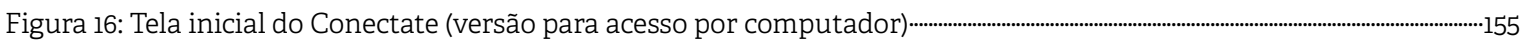

Figura 17: Esquema metodológico para criação de um Nó da rede dos Polos Audiovisuais …….................................................................170

Figura 18: Organizações ativas nos Nós Audiovisuais em 2012, por tipo e quantidade.....................................................................................173

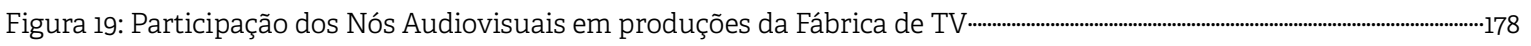

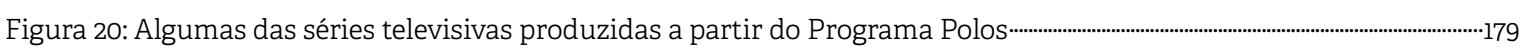

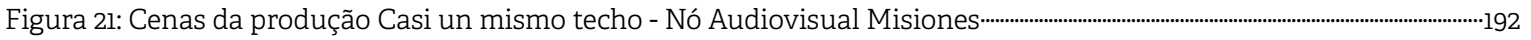

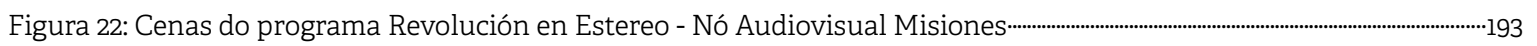

Figura 23: Divulgação do I Fórum de Políticas Públicas Audiovisuais de Misiones.............................................................................................195

Figura 24: Licenças e autorizações outorgadas pela AFSCA (2009-2015) por setor …….............................................................................................216

Figura 25: Licenças e autorizações outorgadas pela AFSCA (2009-2015) ao setor sem fins lucrativos, por meio e tipo de

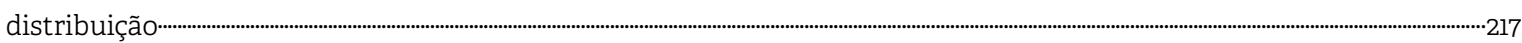

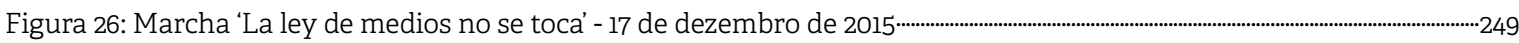

Figura 27: Protesto em frente ao ENACOM pelo pagamento do fundo de fomento à comunicação comunitária - julho de $2016 \cdots$

\section{Lista de tabelas}

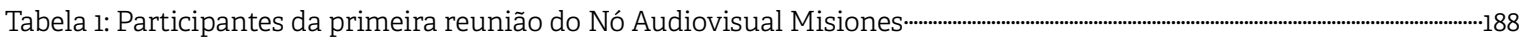

Tabela 2: Origem da programação - Televisão pública e canais privados - Buenos Aires …………………….............................................229

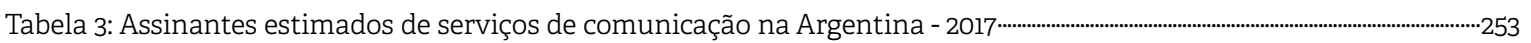




\section{Lista de quadros}

Quadro 1: Eventos globais sobre a NOMIC nos âmbitos da ONU, UNESCO e MNA - 1973 a 1980*.

Quadro 2: Combate à monopolização na Lei de Serviços de Comunicação Audiovisual (26.522/2009) - limites à concentração de licenças (artigo 45).

Quadro 3: Principais momentos da judicialização da LSCA na disputa com o Grupo Clarín ……...............................................................91

Quadro 4: Espectro radioelétrico - características da transmissão por banda de frequências -.....................................................................121

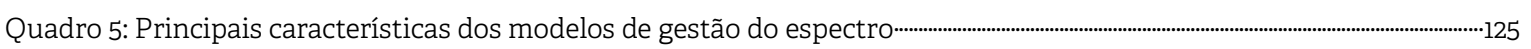

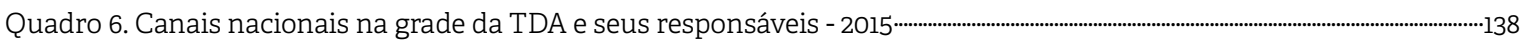

Quadro 7: Características das aplicações de serviço audiovisual por internet -.................................................................................................................152

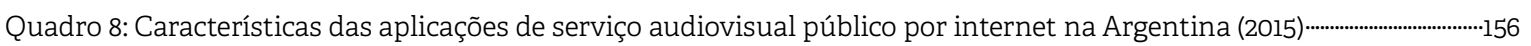

Quadro 9: Divisões regionais acrescentadas pelos principais estudos de regionalizações na Argentina, de 1839 a 1988 -.....165

Quadro 10: Programas dos Nós Audiovisuais veiculados em canais locais

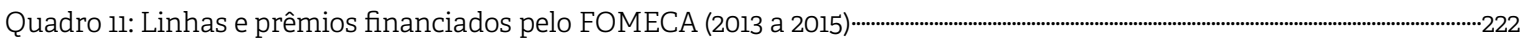

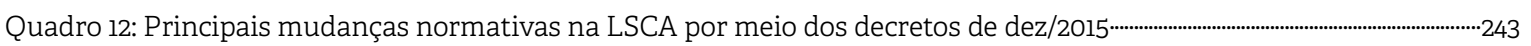

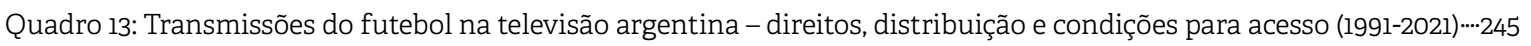

Quadro 14: Cronologia das principais transformações normativas à comunicação audiovisual e alguns marcos da resistência - seis primeiros meses do governo Mauricio Macri-

Quadro 15: Dinâmicas principais das políticas de comunicação para meios sem fins lucrativos e comunicação alternativa, popular e comunitária na Argentina (1980-2017).

\section{Lista de mapas}

Mapa 1: Estações Digitais de Transmissão da Televisão Digital Aberta (TDA) construídas entre 2010 e 2015, por ano de início de operação

Mapa 2: Topologia da TDT no território argentino - sobreposição das Estações Digitais de Transmissão com dados populacionais (2015)

Mapa 3: Cobertura da TDT no território argentino - Estações Digitais de Transmissão (2017)..........................................................136

Mapa 4: Polos Audiovisuais e Universidades Coordenadoras.

Mapa 5: Nós Audiovisuais impulsionados para a conformação da rede federal do Programa Polos Audiovisuais Tecnológicos

Mapa 6: Organizações que aderiram formalmente aos Nós Audiovisuais (2014) ...........................................................................................174

Mapa 7: Centros Públicos de Produção Audiovisual (CEPAs) instalados...................................................................................................175

Mapa 8: Desenvolvimento dos Nós Audiovisuais - Programa Polos Audiovisuais Tecnológicos (2014)........................................204

Mapa 9: Licenças e autorizações de rádio e televisão emitidas pela AFSCA (2009-2015) para meios sem fins lucrativos por

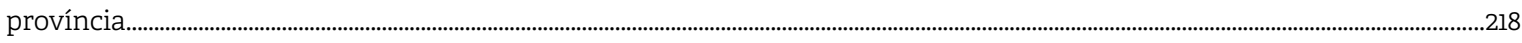

Mapa 10: Licenças e autorizações de televisão outorgadas pela AFSCA (2009-2015) por província e tipo.....................................219

Mapa 11: Organizações registradas pela AFSCA (2015) em zonas de conflito do espectro radioelétrico.........................................220

Mapa 12: Distribuição dos prêmios FOMECA por província (2013 a 2015) (...........................................................................................................223 


\section{Lista de abreviaturas e siglas}

7D - 7 de Diciembre (7 de Dezembro)

ABERT - Associação Brasileira de Emissoras de Rádio e Televisão

ABRAÇO - Associação Brasileira de Rádios Comunitárias

Abranet - Associação Brasileira de Internet

ABTA - Associação Brasileira de TV por Assinatura

ACUA - Argentinos Cuentan Argentina (Argentinos Contam Argentina)

Adjori Brasil - Associação Nacional de Jornais do Interior do Brasil

AFA - Asociación del Fútbol Argentino (Associação do Futebol Argentino)

AFSCA - Autoridad Federal de Servicios de Comunicación Audiovisual (Autoridade Federal de

Serviços de Comunicação Audiovisual)

AFTIC - Autoridad Federal de Tecnologías de la Información y las Comunicaciones (Autoridade

Federal de Tecnologias da Informação e das Comunicações)

AGA - Área Geográfica Audiovisual

ALAI - Agência Latino-americana de Informação

ALER - Associação Latino-americana de Educação e Comunicação Popular

Amarc - Associação Mundial de Rádios Comunitárias

AMBA - Área Metropolitana de Buenos Aires

ANER - Associação Nacional dos Editores de Revistas

ANJ - Associação Nacional de Jornais

APC - Associação para o Progresso das Comunicações

ARBIA - Asociación de Radiodifusoras Bonaerenses y del Interior de la República Argentina

(Associação das Radiodifusoras de Buenos Aires e do Interior da República Argentina)

ARSAT - Empresa Argentina de Soluciones Satelitales (Empresa Argentina de Soluções Satelitais)

ARPA - Asociación de Radiodifusoras Privadas Argentinas (Associação de Radiodifusoras Privadas Argentinas)

ARUNA - Asociación de Radiodifusoras Universitarias Nacionales Argentinas (Associação de Radiodifusoras de Universidades Nacionais Argentinas)

ATA - Asociación de Teleradiodifusoras Argentinas (Associação de Telerradiodifusoras Argentinas)

Ateco - Asociación Argentina de Teledifusoras Comunitarias (Associação Argentina de Teledifusoras Comunitárias)

ATSC - Advanced Television System Committee (Comitê do Sistema Avançado de Televisão)

ATT - Autoridad de Regulación y Fiscalización de Telecomunicaciones y Transportes (Autoridade de Regulação e Fiscalização de Telecomunicações e Transportes)

BACUA - Banco Audiovisual de Contenidos Universales Argentino (Banco Audiovisual de Conteúdos Universais Argentino)

Bartolinas - Confederación Nacional de Mujeres Campesinas Indígenas Originarias de Bolivia

"Bartolina Sisa" (Confederação Nacional de Mulheres Campesinas Indígenas Originárias da Bolívia "Bartolina Sisa")

CABA - Ciudad Autónoma de Buenos Aires (Cidade Autônoma de Buenos Aires)

CCD - Coalición por una Comunicación Democrática (Coalizão por uma Comunicação Democrática)

CDA - Contenidos Digitales Abiertos (Conteúdos Digitais Abertos)

CELS - Centro de Estudios Legales y Sociales (Centro de Estudos Legais e Sociais)

CEMCI - Comisión Empresarial de Medios de Comunicación Independiente (Comissão Empresarial de Meios de Comunicação Independente)

CEPA - Centro Público de Producción Audiovisual (Centro Público de Produção Audiovisual)

CEPAL - Comissão Econômica Para a América Latina

CePIA - Centro de Producción e Investigación Audiovisual

CIDH - Comissão Interamericana de Direitos Humanos

CIDOB - Confederación de Pueblos Indígenas de Bolivia (Confederação de Povos Indígenas da Bolívia)

CIN - Conselho Interuniversitário Nacional

Cocode - Consejo para la Consolidación de la Democracia (Conselho para a Consolidação da 


\section{Democracia)}

Cofeca - Consejo Federal de Comunicación Audiovisual (Conselho Federal de Serviços de

Comunicação Audiovisual)

Colsecor - Cooperativa de Provisión y Comercialización de Servicios Comunitarios de Radiodifusión

Comfer - Comité Federal de Radiodifusión (Comitê Federal de Radiodifusão)

Conamaq - Consejo Nacional de Ayllus y Markas del Qullasuyu (Conselho Nacional de Ayllus e Markas del Qullasuy)

Conatel - Comisión Nacional de Telecomunicaciones (Comissão Nacional de Telecomunicações)

Cordicom - Consejo de Regulación y Desarrollo de la Información y Comunicación (Conselho de Regulação e Desenvolvimento da Informação e Comunicação)

COSECCTI - Conselho Sul-americano de Educação, Cultura, Ciência, Tecnologia e Inovação

CRD - Coalición por una Radiodifusión Democrática (Coalizão por uma Radiodifusão Democrática)

CSCIB - Confederación Sindical de Comunidades Interculturales de Bolivia (Confederação

Sindicalista de Comunidades Interculturais da Bolívia)

CSUTCB - Confederación Sindical Única de Trabajadores Campesinos de Bolivia (Confederação

Sindical Única de Trabalhadores Campesinos da Bolívia)

EDT - Estações Digitais de Transmissão

Enacom - Ente Nacional de Comunicaciones (Ente Nacional de Comunicações)

ENERC - Escuela Nacional de Experimentación y Realización Cinematográfica

FARCO - Foro Argentino de Radios Comunitarias (Fórum Argentino de Rádios Comunitárias)

FITTEL - Federação Interestadual dos Trabalhadores em Empresas de Telecomunicação

FITERT - Federação Interestadual dos Trabalhadores em Empresas de Rádio e Televisão

FLACSO - Facultad Latinoamericana de Ciencias Sociales (Faculdade Latino-americana de Ciências Sociais)

FM - Frequência Modulada

FOMECA - Fondo de Fomento Concursable para Medios de Comunicación Audiovisual (Fundo de

Fomento Concursável para Meios de Comunicação Audiovisual)

FOPEA - Foro de Periodismo Argentino (Fórum de Jornalismo Argentino)

FpV - Frente para la Victoria (Frente para a Vitória)

FSM - Fórum Social Mundial

GATT - General Agreement on Tariffs and Trade (Acordo Geral de Tarifas e Comércio)

HMT\&F - Hicks, Muse, Tate \& Furst

IAAVIM - Instituto de Artes Audiovisuales de Misiones

INCAA - Instituto Nacional de Cinema e Artes Audiovisuais

IPTV - Internet Protocol Television

ISDB-T - Integrated Services Digital Broadcasting Terrestrial (Serviço Integrado de Transmissão

Digital Terrestre)

LSCA - Ley de Servicios de Comunicación Audiovisual (Lei de Serviços de Comunicação Audiovisual)

Mercosul - Mercado Comum do Sul

MNA - Movimento dos Não-Alinhados

NACNAP - Punto Nacional de Acceso a la Red (Ponto Nacional de Acesso à Rede)

NACNOC - Centro Nacional de Operaciones (Centro Nacional De Operações)

NAT - Nodo Audiovisual Tecnológico (Nós Audiovisuais Tecnológicos)

NEA - Nordeste Argentino

NOA - Noroeste Argentino

NOEI - Nova Ordem Econômica Internacional

NOMIC - Nova Ordem Mundial da Informação e da Comunicação

Observacom - Observatório Latino-americano de Regulação, Meios e Convergência

OEA - Organização dos Estados Americanos

OMC - Organização Mundial do Comércio

ONU - Organização das Nações Unidas

OTT - Over-the-top

PAT - Polos Audiovisuales Tecnológicos (Polos Audiovisuais Tecnológicos)

PNBL - Plano Nacional de Banda Larga 
PPGA - Planejamento Participativo e Gestão Associada

PRONAP - Puntos Provinciales de Acceso a la Red (Pontos Provinciais de Acesso à Rede)

PRONOC - Centros Provinciales de Operación (Centros Provinciais de Operação)

RECAM - Reunião Especializada de Autoridades Cinematográficos e Audiovisuais do Mercosul

REDECOM - Red de Carreras de Comunicación Social y Periodismo de Argentina

REFEFO - Red Federal de Fibra Optica (Rede Federal de Fibra Óptica)

RENAU - Red Nacional Audiovisual Universitaria (Rede Nacional Audiovisual Universitária)

Resorte - Ley de Responsabilidad Social en Radio y Televisión

RPO - Radio de los Pueblos Originario (Rádio dos Povos Originários)

RRULAC - Red de Radios Universitarias de América Latina y el Caribe

RT - Russia Today

RTA - Radio y Televisión Argentina

SATSAID - Sindicato Argentino de Televisión, Servicios Audiovisuales, Interactivos y de Datos

(Sindicato Argentino de Televisão, Audiovisual, Serviços Interativos e de Dados)

SATVD-T - Sistema Argentino de Televisión Digital Terrestre (Sistema Argentino de Televisão Digital Terrestre)

SBTVD-TB - Sistema Brasileiro de Televisão Digital Terrestre

SECOM - Secretaria de Comunicação Social da Presidência da República

SFMCP - Sistema Federal de Medios y Contenidos Publicos (Sistema Federal de Meios e Conteúdos

Públicos)

SIPREBA - Sindicato de Prensa de Buenos Aires (Sindicato de Imprensa de Buenos Aires)

SIPTED - Sistema Provincial de Teleducación y Desarrollo (Sistema Provincial de Teleducação e

Desenvolvimento)

Supercom - Superintendencia de Información y Comunicación (Superintendência de Informação e

Comunicação)

TDA - Televisão Digital Aberta

TDT - Televisão Digital Terrestre

Telesur - Televisión del Sur (Televisão do Sul)

TV - Televisão

UBA - Universidad de Buenos Aires (Universidade de Buenos Aires)

UNA - Universidad Nacional de las Artes (Universidade Nacional das Artes)

UNAJ - Universidad Nacional Arturo Jauretche (Universidade Nacional Arturo Jauretche)

UNAM - Universidad Nacional de Misiones (Universidade Nacional de Misiones)

UNER - Universidad Nacional de Entre Ríos (Universidade Nacional de Entre Ríos)

Unasul - União de Nações Sul-americanas

UNESCO - United Nations Educational, Scientific and Cultural Organization (Organização das

Nações Unidas para a Educação, a Ciência e a Cultura)

UNLa - Universidad Nacional de Lanús (Universidade Nacional de Lanús)

UIT - União Internacional de Telecomunicações

VOD - Video on Demand (Vídeo sob Demanda) 


\section{Sumário}

Introdução.

1. Comunicação e usos do território: da violência da informação a uma outra globalização........39

1.1. Globalização, violência da informação e os monopólios midiáticos na formação socioespacial argentina.

1.2. A psicosfera e as disputas por uma regulação democrática da comunicação na Argentina..57

2. As transformações normativas para a democratização da comunicação audiovisual na

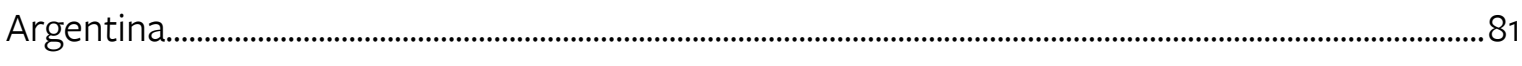

2.1. As normas argentinas para a comunicação e o combate à violência da informação...................84

2.2. Aproximações e distanciamentos entre as políticas de regulação da comunicação na América Latina.

3. As redes técnicas no território argentino e as condições infraestruturais para a democratização da comunicação. .115

3.1. Disputas pelo espectro radioelétrico: entre a razão neoliberal e “a reforma agrária do ar"...119

3.2. Expansão da rede de televisão digital no território argentino: tentativas de capilarização de uma outra infraestrutura.

3.3. A internet, o audiovisual ampliado e as ações para o alargamento das bases técnicas na convergência.

4. Promoção da comunicação ascendente no território argentino. .161

4.1. O programa Polos Audiovisuais e a regionalização da produção audiovisual. .162

4.2. Condições para o audiovisual sem fins lucrativos nos espaços opacos da globalização.......208

5. Reorientação das políticas de comunicação e realinhamento com os conglomerados midiáticos.

5.1. Das disputas na psicosfera ao desmonte normativo e institucional 237

5.2. O aprofundamento da violência da informação e a negação da pluralidade. .251

Conclusões 265

Referências bibliográficas. 276 
introdução 


\section{Introdução}

No século XVI, alguns teólogos da Igreja Católica legitimavam a conquista da América em nome do direito da comunicação. Jus communicationis: os conquistadores falavam, os índios escutavam. A guerra era inevitável justamente quando os índios se faziam de surdos. Seu direito de comunicação consistia no direito de obedecer. No fim do século XX, aquela violação da América ainda se chama encontro de culturas, enquanto continua se chamando comunicação o monólogo do poder.

Eduardo Galeano. Curso intensivo de incomunicação. De pernas pro ar: a escola do mundo ao avesso (2011).

El terror se basa en la incomunicación. Vuelva a sentir la satisfacción moral de un acto de libertad. Derrote al terror. Haga circular esta información.

Rodolfo Walsh. Cadena Informativa (1976), em Verbitsky (1985, p. 38).

A epígrafe de Eduardo Galeano remete à urgência de promover comunicação em um sistema midiático marcado pela intensa concentração do poder de produzir e circular informações e de construir e difundir imaginários. A disputa de projetos da sociedade marca a organização do espaço geográfico, e esses projetos "resultam do sistema de valores, tradições, atitudes culturais, sociais e políticas" (ISNARD, 1982, p. 37). Não havendo pluralidade e diversidade de ideias e sentidos em circulação no território, limita-se a possibilidade de criar, a partir dos lugares, projetos diferentes daqueles que atendem aos interesses dos agentes dominantes. Buscando romper com a incomunicação, uma grande diversidade de movimentos sociais disputou, em diferentes territórios da América Latina, transformações na organização da comunicação para dar voz a agentes e lugares historicamente marcados pelo silenciamento.

$\mathrm{Na}$ Argentina, o debate sobre os monopólios midiáticos e a necessidade de democratizar a comunicação foi gestado desde o fim da última ditadura, em 1983, e ganhou grande espaço no debate público em 2009, no contexto da discussão de uma nova Lei de Serviços de Comunicação Audiovisual (LSCA), conhecida popularmente como Ley de Medios. O projeto de lei foi 
construído a partir de propostas promovidas por movimentos sociais e outros agentes da sociedade civil (SEGURA, 2011) e foi aprovado e sancionado no mesmo ano. O tema virou o centro de disputas envolvendo grandes corporações midiáticas, movimentos sociais, meios comunitários e governos.

A informação se tornou matéria-prima essencial dos negócios e empresas em ascensão (GOTTMANN, 1977, p. 597) e, também, um instrumento da união entre as diversas partes de um território (SANTOS, 1994, p. 16) e, junto da técnica e da ciência, o locus essencial da acumulação de capital na economia mundial (SCHILLER, 1988, p. 27); em decorrência disso, o comando das redes de informação tem se tornado cada vez mais estratégico aos agentes dominantes. Conforme Dollfus (2002, p. 35), a comunicação exerce um papel fundamental na configuração dos lugares do poder. Assim, aliando o papel econômico dos grupos de comunicação à sua atuação na produção e difusão de sentidos, a necessidade de uma agenda de desconcentração desse poder e de promoção de condições para ampliar os agentes com voz nos lugares se revela ainda mais central às perspectivas democráticas de organização do espaço.

Desse modo, os processos de disputa pela organização da comunicação no território argentino são reveladores das desigualdades socioespaciais e permitem vislumbrar possibilidades e limites das políticas de comunicação em promover transformações nas condições da troca efetiva de informações a partir dos lugares. A leitura desses processos aqui proposta exige um diálogo interdisciplinar entre Geografia e Comunicação.

\section{Caminhos de um diálogo interdisciplinar}

A interface interdisciplinar entre Geografia e Comunicação ganhou relevância nas últimas décadas, com a ascensão da informação e da comunicação como variáveis-chave do atual período histórico e das dinâmicas do espaço geográfico, bem como da importância crescente e estratégica da Geografia em função das novas possibilidades de uso do território a partir da 
globalização. Nesse contexto, busca-se desvendar caminhos profícuos de diálogo entre as duas disciplinas.

Como afirma Milton Santos (2004, p. 141), o trabalho de pesquisa interdisciplinar deve ser feito a partir do próprio objeto de nossa disciplina. Segundo o autor, evita-se, assim, a construção de explicações superficiais que partiriam de uma compreensão pobre das disciplinas vizinhas. Na mesma direção, tratando do diálogo interdisciplinar entre Geografia e Comunicação, Aguiar Lopes (2013, p. 32) afirma que "da mesma forma que, durante muito tempo, os geógrafos se agarraram à metáfora dos meios de comunicação como [...] 'canais' entre um sujeito e o mundo exterior, também os pesquisadores da Comunicação priorizam o uso metafórico do espaço e da espacialidade". A mesma autora afirma, ainda, que

\footnotetext{
Em pouco mais de uma década, o número de livros e artigos [de Comunicação] que utilizam referenciais geográficos em seus estudos sobre fenômenos e tecnologias da comunicação e da mídia aumentou exponencialmente no mundo anglo-saxônico, especialmente na Inglaterra e nos países nórdicos. Em geral, as análises orientam-se por noções de espaço, espaço-tempo e território que nem sempre são ancoradas em uma base epistemológica da ciência geográfica, incluindo suas controvérsias teóricas. Na maior parte dos casos, sequer há geógrafos na bibliografia trabalhada. Os conceitos de caráter geográfico muitas vezes são citados de segunda mão, a partir de filósofos, sociólogos, antropólogos, cientistas políticos ou são originados destes, como acontece nas Geografias Cultural e Social (AGUIAR LOPES, 2013, p. 32, grifo próprio).
}

Para evitar essa banalização ou desfiguração de conceitos, Ribeiro (2012a, p. 35) ressalta a importância do cuidado com a história singular de cada disciplina e do reconhecimento de seus pressupostos metodológicos. Assim, reconhecendo a porosidade das fronteiras disciplinares (RIBEIRO, 2012a, p. 120), a interdisciplinaridade é estruturada, neste trabalho, partindo de um sistema de conceitos da Geografia, em busca da construção das relações com outros campos. 
Diversos pesquisadores da Geografia e da Comunicação trouxeram contribuições para esse diálogo interdisciplinar, de maneira mais ou menos explícita e estruturada. Segundo Hillis (1998, p. 543), no campo de pesquisas geográficas, a comunicação e suas tecnologias foram objeto de uma atenção irregular por parte da Geografia Humana. Focado na análise da produção geográfica anglo-saxônica, o autor considera que desde os anos 1960 - até os anos 1990, data de publicação de sua análise -, com poucas exceções, o tema das comunicações não foi suficientemente investigado, analisado e teorizado. Ele menciona exceções como Gottmann (1977), Hepworth (1989) e Adams (1993). A escola sueca de Geografia trouxe contribuições para a análise da informação e da comunicação (CONTEL, 2011; PASTI, 2015). Destacam-se as obras de Hägerstrand, cujos esforços analíticos de maior destaque foram: (a) os debates sobre a "difusão espacial de inovações" (HÄGERSTRAND, 2013), (b) a mobilidade e a migração e (c) uma "geografia do tempo" (CONTEL, 2011; THRIFT, 2005).

Diversos outros pesquisadores contribuíram com esse diálogo interdisciplinar, entre os quais destacamos Jasper Falkheimer e André Jansson (2006), que abordam a geografia a partir da comunicação; Barney Warf (1995, 2011, 2012), que aborda temas de Internet e telecomunicações na Geografia; e Chris Lukinbeal e Stefan Zimmermann (2008), com estudos sobre mídia e cinema no campo da Geografia cultural. Entre as referências da Geografia anglo-saxônica, no campo que se estabeleceu sob a denominação de Geografias da Comunicação, cabe destacar as obras de Adams (2011, 2016, 2017), na perspectiva da geografia humanista. Analisando trabalhos que tratam desse diálogo interdisciplinar a partir das relações entre espaço, lugar e mídia, Adams organizou as diferentes abordagens em um quadrante: lugar-na-mídia, espaço-na-mídia, mídia-no-lugar e mídia-no-espaço (ADAMS, 2011, p. 40). Com o avanço desses estudos

Em sua crítica às teorias de difusão das inovações e das informações, Milton Santos afirma que "Hägerstrand atribui mais influência efetiva às relações interpessoais do que aos meios de comunicação de massa" (SANTOS, 2003, p. 79) para a difusão de informações, além de afirmar que os modelos criados de difusão de informações pressupõem que se poderia teorizar sobre esse tema com base em "regularidades empíricas observadas". 
interdisciplinares nos Estados Unidos, a Associação Americana de Geógrafos (AAG) criou um grupo sob o tema "Geografia da Comunicação e da Mídia" (AAG, 2018). Aguiar Lopes (2013, p. 33) conta que esse campo de pesquisas vem se organizando em torno de quatro eixos principais de investigação:

[1] o papel do espaço e da espacialidade como categorias analíticas das variadas formas de expressão e comunicação humanas; [2] a organização e disseminação territorial das tecnologias de informação e comunicação, com ênfase mais recente na internet e nos dispositivos móveis; [3] as geografias dos sistemas de mídia nos contextos da globalização e da regionalização, com imbricações na economia política; e [4] a geopolítica dos fluxos e contrafluxos de informação e comunicação em âmbito mundial, tanto via sistemas corporativos transnacionais quanto por meio de mídias sociais alternativas.

A autora ressalta que essas vertentes ainda se orientam fortemente pelas perspectivas epistemológicas e por visões de mundo marcadas por olhares anglo-saxônicos ou europeus, tanto em termos teóricos quanto dos objetos e recortes empíricos privilegiados. Ela aponta a necessidade de uma "agenda de pesquisa sob uma perspectiva do Hemisfério Sul, que atenda a demandas de investigação latino-americanas" (AGUIAR LOPES, 2013, p. 33). Ribeiro (2010) também traz atenção aos servilismos que dificultam a produção de teorias e conceitos a partir da realidade latino-americana. Para Silveira (2006, p. 86), “a América Latina pede uma teoria do espaço fundada na nossa própria história".

No caso da Geografia brasileira, partindo de um entendimento amplo dessas pesquisas com alguma interface entre Geografia e Comunicação², José

2 No âmbito da área de Comunicação, Melo (2010) considera que um dos autores fundamentais e precursor dessas contribuições teria sido o canadense Harold Innis (1894-1952). Segundo o autor, Innis teria oxigenado e ampliado os estudos sobre o desenvolvimento dos atos comunicacionais, dialogando com a geografia, a história e a economia. No Brasil, o desenvolvimento desse trabalho interdisciplinar se deu, em parte, baseado no diálogo com a Geografia brasileira - Melo (2010) cita a ocasião do Encontro Internacional Novo Mapa do Mundo (1992), organizado por Milton Santos e Maria Adélia de Souza na Universidade de São Paulo, e diversos encontros da Sociedade Brasileira de Estudos Interdisciplinares de Comunicação (Intercom) em que temas como classes subalternas, contrainformação, comunicação rural e globalização e regionalização foram tratados. Além disso, foram fundamentais as agendas de pesquisa que exigiram aportes da Geografia. No entanto, apenas em 2008 ocorreu a institucionalização desse trabalho interdisciplinar, com a criação de um Grupo de Pesquisa dedicado à Geografia da Comunicação no âmbito da Intercom. Esse grupo tem produções "que dialogam com várias áreas e fronteiras do conhecimento. Essa peculiaridade estava presente na sua primeira reunião que incluiu temas como comunicação internacional, comunicação Sul-Sul, comunicação 
Marques de Melo (2010) considera que existiriam vestígios de incursões na área bem antigas, configurando "uma espécie de geografia precoce da comunicação brasileira". Para este autor, alguns dos intelectuais que teriam trazido contribuições nesse sentido seriam Caio Prado Jr., Sérgio Buarque de Holanda e Fernando de Azevedo, da Universidade de São Paulo. O autor destaca a contribuição do geógrafo Manuel Correia de Andrade - que abordou a relação entre proximidade e afastamento - com um componente comunicacional - e as "dificuldades de comunicação" (ANDRADE, 1996).

Desde especialmente os anos 1970, a Geografia latino-americana tem trazido importantes contribuições aos estudos de Comunicação e constituído agendas de pesquisas com base em problemáticas próprias aos territórios da América Latina, considerando as suas especificidades. Esse é o nosso ponto de partida para a pesquisa aqui realizada.

\section{Fundamentos teóricos: do território usado à comunicação ascendente}

Para investigar a América Latina na aurora do século XXI, Arroyo (2015, p. 16, 2017, p. 14) propõe a consideração dos territórios nacionais

não como substratos materiais vazios e inertes, mas como âmbitos usados por múltiplos agentes com diferentes força e poder, com distintas capacidades de usar e controlar sua bases naturais e técnicas assim como de definir e regular suas bases normativas e políticas, e com uma diversidade de imaginários, representações e interpretações.

É nesse sentido que este trabalho busca analisar as transformações na organização da comunicação no território argentino. Apresentamos, aqui, parte dos princípios de método que organizam este trabalho, sobretudo a partir de um diálogo entre as obras do geógrafo Milton Santos e da socióloga Ana Clara Torres

intercultural, comunicação e geografia, comunicação e migração, comunicação e espaço urbano, diversidade cultural, construção de territórios simbólicos na mídia, geografia e política, convergência de mídia, bases de dados geográficos e mídia de fronteira. Essa abrangência significa que a Geografia não é mais tão 'invisível' para a Comunicação" (BALDESSAR; MOREIRA; PASTI, 2014, p. 522). 
Ribeiro3.

Esta pesquisa parte de um esforço de leitura do espaço geográfico da atualidade, entendido como "um conjunto indissociável, solidário e também contraditório, de sistemas de objetos e sistemas de ações, não considerados isoladamente, mas como o quadro único no qual a história se dá" (SANTOS, 2006, p. 63). Na perspectiva de Santos (1994, p. 15-16), o que interessa à análise social não é o território em si, mas o uso do território, o território usado. Para o autor, o território são as formas, mas o território usado são os objetos e ações. Segundo Santos e Silveira (2001, p. 247), para definir um território "devemos levar em conta a interdependência e a inseparabilidade entre a materialidade, que inclui a natureza, e seu uso, que inclui a ação humana, isto é, o trabalho e a política". O território usado pode ser entendido, também, como território praticado, conforme Ribeiro (2013a, p. 150).

Segundo Dollfus (1991, p. 11), o espaço geográfico se acha impregnado de história e a análise das sucessivas heranças permite que se rastreiem as evoluções. Nesse sentido, é importante considerar as especificidades de cada formação socioespacial. Com base no conceito de formação social e econômica, de Karl Marx, Milton Santos (1977, 2008a) incorporou a consideração do espaço, propondo a categoria de formação socioespacial. Para o autor (SANTOS, 2008a, p. 22),

esta categoria diz respeito à evolução diferencial das sociedades, no seu quadro próprio e em relação com as forças externas de onde mais frequentemente lhes provém o impulso. A própria base da explicação é a produção, isto é, o trabalho do homem para transformar, segundo leis historicamente determinadas, o espaço com o qual o grupo se confronta.

É necessário definir a especificidade de cada formação, o que a distingue das outras e, no interior dela, a apreensão do particular como uma

3 Como conta Ana Clara Torres Ribeiro (2012a, p. 35-41), os autores desenvolveram um profícuo diálogo em vida. Silva Neto (2017, p. 2), considera que como interlocutora reconhecidamente muito ativa da obra de Milton Santos, a contribuição primordial da socióloga seria, em princípio, identificar e esclarecer as intrincadas associações entre técnica, tecnologia, sociedade, cultura e território. 
fração do todo, um momento do todo, assim como o todo reproduzido numa de suas frações (SANTOS, 2008a, p. 25). O estudo da América Latina deve partir do reconhecimento de sua formação comum, entendendo-a como uma totalidade ${ }^{4}$, e estudar as distintas formações socioespaciais (LEMOS, 2006, p. 29-30). Assim, nesta tese, coloca-se centralidade no conceito de formação socioespacial para o entendimento do processo de disputas pela organização da comunicação na Argentina.

As políticas para a democratização da comunicação na Argentina não serão analisadas, aqui, apenas a partir do texto previsto em lei e de sua aplicação por parte dos governos nacionais. Partimos do reconhecimento do papel ativo do território usado nas condições para a realização dos projetos de organização da comunicação nos lugares. Assim, o conjunto de ações que acompanha a discussão, aprovação e efetivação das políticas de comunicação na Argentina no marco da Lei de Serviços de Comunicação Audiovisual são entendidas, aqui, como um evento geográfico. A noção de evento, proposta por Santos (1999, p. 16), é um caminho de método para o desafio teórico da inseparabilidade entre espaço e tempo - considerando a empiricidade do tempo, sua historicidade, que estaria atrás de sua realização histórica e geográfica. Para o autor, o mundo é um conjunto de possibilidades, e o evento é o veículo de uma ou algumas dessas possibilidades, podendo atuar, também, como o vetor de possibilidades (SANTOS, 2006, p. 144). O presente é fugaz e sua análise se realiza sempre a partir de dois polos: o futuro como projeto e o passado como realização já produzida (SANTOS, 1999, p. 15). Daí a importância de considerar os eventos, suas diferentes

4 Para Santos (1984, p. 8), o espaço é um campo de forças multidirecionais e multicomplexas onde, ao mesmo tempo em que cada lugar é extremamente diferente de outro, também cada lugar está claramente ligado a todos os outros por um nexo único, dado pelas forças motrizes do modo de acumulação hegemonicamente universal. Desse modo, não se deve analisar os lugares por meio de lógicas particulares e encerradas em si, sem a consideração da totalidade. Essa totalidade está sempre em movimento, que é chamado de totalização. “Trata-se de uma totalização que se totaliza incessantemente; os fatos particulares não significam nada, não são verdadeiros ou falsos enquanto não forem referidos pela mediação de diferentes totalidades parciais à totalização em andamento" (SARTRE, 2002, p. 36). A totalidade representa um resultado momentâneo desse processo. Os sistemas de objetos e sistemas de ações são novas totalidades dessa totalidade em movimento: o espaço (SILVEIRA, 2000, p. 25). Entender o movimento é crucial: o processo histórico é esse processo de totalização (SARTRE, 2002), que dá às velhas coisas um novo conteúdo, conduzindo da velha à nova totalidade e sendo a base do conhecimento de ambas (SANTOS, 2006, p. 120). 
durações, sobreposições, extensões e escalas. O evento permite unir o mundo ao lugar - o lugar é o depositário final do evento, que traz ao lugar novos conteúdos (SANTOS, 2006, p. 146).

Para abordar as diferenciações no território a partir das dinâmicas da informação e da comunicação, nos baseamos nas diferentes cargas de conteúdo técnico, informacional e comunicacional que os espaços apresentam no período atual, criando diferentes densidades, conforme propõe Santos (2006). A densidade técnica seria dada pelos graus de artifício, variando do espaço jamais tocado pelo homem até a prevalência dos objetos técnicos (SANTOS, 2006, p. 257). A densidade informacional nos indica o grau de exterioridade do lugar e a realização de sua propensão a entrar em relação com outros lugares, já que a informação introduz uma intervenção vertical no espaço, que geralmente ignora seu entorno. Já a densidade comunicacional resulta do tempo plural do cotidiano partilhado - o tempo conflitual da copresença - estando ligada às dinâmicas horizontais de trocas do lugar (SANTOS, 2006, p. 258).

Partindo desse entendimento, ao analisar a produção e circulação de informações no espaço geográfico, Silva (2010) considera a existência de círculos informacionais ascendentes e descendentes, coexistindo no espaço geográfico. Os círculos descendentes são aqueles baseados na informação que atinge verticalmente os lugares. Conforme Santos (2006, p. 257), "a informação unívoca, obediente às regras de um ator hegemônico, introduz, no espaço, uma intervenção vertical, que geralmente ignora seu entorno, pondo-se a serviço de quem tem os bastões de comando". Por outro lado, os círculos informacionais ascendentes referem-se aos "dinamismos mais arraigados ao lugar, ao dilema da sobrevivência, da resistência e da reprodução" (SILVA, 2010, p. 2).

Articulando esse entendimento com as densidades técnica, informacional e comunicacional, podemos falar em uma comunicação ascendente em oposição às informações descendentes. Essa comunicação ascendente parte da troca efetiva de informações fundadas no cotidiano 
compartilhado, baseadas em dinâmicas de solidariedade orgânica ${ }^{5}$ dos lugares, produzidas a partir de saberes locais nutridos pelo cotidiano (SANTOS, 1999, p. 21). Nos dizeres de Gorz (2005, p. 9), são as "formas de saber que não são substituíveis, que não são formalizáveis: o saber da experiência, o discernimento, a capacidade de coordenação, de auto-organização e de comunicação. Em poucas palavras, formas de um saber vivo adquirido no trânsito cotidiano, que pertencem à cultura do cotidiano".

O esforço deste trabalho parte desses conceitos, ao investigar se as políticas de comunicação audiovisual no marco da LSCA apontam para a ampliação da densidade comunicacional dos lugares e para a comunicação ascendente. Esse entendimento está articulado, também, com alguns princípios éticos e científicos propostos por Ribeiro (2012a, p. 118-122), entre eles: o reconhecimento da incerteza, que propõe realizar análise de processos ainda "em aberto", escutando as vozes dos muitos outros; e o reconhecimento de racionalidades alternativas, da condição de sujeito dos muitos outros, do poder de determinação do social e da força criadora da sociabilidade, todos esses em diálogo com a abertura para a potência dos agentes dos lugares de construir processos para além dos agenciamentos externos que os reduzem. Esses princípios fundamentam escolhas metodológicas apresentadas a seguir.

\section{Hipótese, procedimentos metodológicos e estrutura da tese}

A partir desses pressupostos, o trabalho tem a seguinte hipótese: a promoção da democratização da comunicação em um território exige a realização de políticas de comunicação, no âmbito do Estado, capazes de transformar as condições normativas, técnicas e de organização dos lugares para ampliar sua densidade comunicacional, fomentando a produção e a circulação de informações ascendentes nos espaços silenciados. Na formação socioespacial

\footnotetext{
5 Segundo Santos e Silveira (2001, p. 306-307), “a solidariedade orgânica resulta de uma interdependência entre ações e atores que emana da sua existência no lugar [...] fruto do próprio dinamismo de atividades cuja definição se deve ao próprio lugar enquanto território usado", enquanto "a solidariedade organizacional supõe uma interdependência até certo ponto mecânica, produto de normas presididas por interesses de modo geral mercantis, mutáveis em função de fatores do mercado".
} 
argentina, as políticas de comunicação audiovisual gestadas nas últimas décadas - a partir de uma multiplicidade de agentes e movimentos sociais - e concretizadas no marco normativo da Lei de Serviços de Comunicação Audiovisual (LSCA, Lei n. 26.522/2009) - apontaram, ainda que em um processo incipiente, para uma reorganização das materialidades e ações ligadas ao audiovisual no território argentino, com o sentido da ampliação da comunicação ascendente, da regionalização do audiovisual e do reconhecimento da comunicação como um direito - portadora, assim, de um sentido antineoliberal e contra-hegemônico. Já o processo de reformulação de políticas de comunicação iniciado ao final de 2015, no governo de Mauricio Macri, é marcado pela desconfiguração da LSCA, pela reorientação do sentido das políticas e normas de comunicação com vistas a um realinhamento entre as ações do Estado e o interesse dos conglomerados midiáticos, com um aprofundamento da violência da informação na formação socioespacial argentina. As novas condições normativas, técnicas e de organização dos lugares decorrentes dessas novas ações do Estado apontam para uma redução da densidade comunicacional e para o fortalecimento dos círculos descendentes de informações.

Para operacionalizar a pesquisa, foi realizado um amplo levantamento bibliográfico - sobretudo no diálogo entre Geografia e Economia Política da Comunicação; foram levantados dados com variadas fontes, tanto oficiais, do Estado e instituições de pesquisa, quanto de movimentos sociais. Além disso, empreendemos diversos trabalhos de campo, muitos deles associados à realização de entrevistas semiestruturadas nos lugares. Ao todo, 32 pessoas foram entrevistadas, em sete diferentes cidades - comunicadores, participantes dos processos estudados e especialistas. Algumas das entrevistas foram realizadas em outros países da região, abordando os processos regulatórios da comunicação nessas formações socioespaciais. Os trabalhos de campo foram viabilizados por viagens pontuais, graças à bolsa de Doutorado do CNPq, e por dois estágios de pesquisa de duração estendida, possibilitados pela Bolsa de 
Doutorado Sanduíche da CAPES no marco do Convênio do Programa de Centros Associados de Pós-Graduação (CAPG/BA), entre a Universidade de São Paulo e a Universidad de Buenos Aires. Um dos estágios de pesquisa teve vinculação à FLACSO-Argentina na investigação sobre os Polos Audiovisuais Tecnológicos, com um significativo acervo de documentos do programa. O detalhamento das atividades consta nos quadros a seguir.

Trabalhos de campo e estágios de pesquisa realizados na Argentina

\begin{tabular}{|c|c|c|}
\hline Data & Local & Atividades realizadas \\
\hline Março/2015 & Buenos Aires & $\begin{array}{l}\text { Visita técnica à AFSCA e Educ.ar, Entrevistas com Facundo Agrelo e } \\
\text { Fernando Torillate. }\end{array}$ \\
\hline $\begin{array}{l}\text { Dezembro/2015 a } \\
\text { Fevereiro/2016 }\end{array}$ & $\begin{array}{l}\text { Buenos Aires e } \\
\text { Banfield }\end{array}$ & $\begin{array}{l}\text { Estágio de pesquisa - convênio USP-UBA. Visitas a meios } \\
\text { comunitários. Entrevistas com Muriel Bernardo, Eliane Gibeaud e } \\
\text { Vivian Elem, Eduardo Rinesi e Gabriel Mariotto. }\end{array}$ \\
\hline $\begin{array}{l}\text { Setembro/2016 a } \\
\text { Dezembro/2016 }\end{array}$ & Buenos Aires & $\begin{array}{l}\text { Estágio de pesquisa - Doutorado Sanduíche, Convênio USP-UBA, com } \\
\text { vínculo à FLACSO-Argentina. Entrevistas com Héctor Poggiese, Eva } \\
\text { Piwowarski, Osvaldo Nemirovsci, María Alvarez Vicente, Fabio Omar } \\
\text { Oliva, José Borello, Facundo Agrelo e Claudia Ducatenzeiler. }\end{array}$ \\
\hline Novembro/2016 & Posadas & $\begin{array}{l}\text { Trabalho de campo - Nó Misiones - Polos Audiovisuais. Entrevistas } \\
\text { com Axel Monsu, Ana Zanotti, Nico Amadio, Alexis Streuli, Hernán } \\
\text { Cazzaniga, Marcelo Rodríguez e Mariana Lombardini. }\end{array}$ \\
\hline Dezembro/2016 & Florencio Varela & $\begin{array}{l}\text { Trabalho de campo - Nó Conurbano Sudeste - Polos Audiovisuais. } \\
\text { Visita Rádio UNAJ. Entrevistas com Gabriel Wainstein, Daniel } \\
\text { Symcha, Luis Rivero e Axel Ribeiro. }\end{array}$ \\
\hline Setembro/2017 & Buenos Aires & Visita à Barricada TV e Entrevista com Natália Vinelli. \\
\hline & & Elaboração própria. \\
\hline \multicolumn{3}{|c|}{ Trabalhos de campo realizados em outros países da região } \\
\hline Data & Local & Atividades realizadas \\
\hline Julho/2015 & $\begin{array}{l}\text { Quito, } \\
\text { Equador }\end{array}$ & $\begin{array}{l}\text { Visita técnica ao Cordicom e à agência de notícias pública do Equador. } \\
\text { Entrevistas com Patricio Barriga e Hernán Reyes. }\end{array}$ \\
\hline Abril/2017 & $\begin{array}{l}\text { La Paz, } \\
\text { Bolívia }\end{array}$ & $\begin{array}{l}\text { Entrevistas com Erick Torrico Villanueva e Bernardo Poma Ulo - } \\
\text { ONG Unir Bolívia. }\end{array}$ \\
\hline Novembro/2016 & $\begin{array}{l}\text { Montevidéu, } \\
\text { Uruguai }\end{array}$ & $\begin{array}{l}\text { Entrevista com Gustavo Gómez Germano - Observatório Latino- } \\
\text { americano de Regulação, Meios e Convergência. }\end{array}$ \\
\hline
\end{tabular}

Elaboração própria.

Dessa maneira, organizamos a tese em cinco capítulos. O primeiro 
aborda a comunicação e os usos do território, partindo do contexto marcado pela monopolização midiática e pela violência da informação até a gestação do projeto de comunicação democrática, articulando o desenvolvimento dessa pauta na formação socioespacial argentina, na América Latina e no mundo. No caso argentino, analisamos disputas pela difusão de um imaginário de sustentação ao projeto de democratização da comunicação e as reações dos grandes conglomerados midiáticos.

No segundo capítulo, são abordadas as novas condições normativas criadas pela Lei de Serviços de Comunicação Audiovisual de 2009 na Argentina, a partir de duas dimensões: o combate à concentração midiática e a promoção de pluralidade e diversidade de vozes. A segunda parte do capítulo procura compreender essas transformações articuladas com a totalidade latinoamericana, buscando aproximações e distanciamentos entre as políticas de regulação da comunicação em diferentes formações socioespaciais da América Latina.

As ações para transformação do conjunto de objetos técnicos e das condições infraestruturais para a democratização da comunicação no marco da LSCA são analisadas no terceiro capítulo, dividido em três partes: a primeira, sobre as disputas pelo espectro radioelétrico; a segunda, abordando a capilarização da rede de televisão digital; e a terceira, discutindo ações ligadas à internet, considerando o contexto do audiovisual na convergência tecnológica.

O quarto capítulo aborda as ações voltadas à promoção das condições para impulsionar a comunicação ascendente e a densidade comunicacional dos lugares. Para isso, é dada ênfase à experiência do programa Polos Audiovisuais Tecnológicos, que buscava regionalizar a produção audiovisual a partir de processos participativos, em uma rede federal de Nós Audiovisuais. São discutidas, ainda, as políticas para a comunicação comunitária, alternativa e popular e princípios de uma experiência de comunicação pública, a partir de um olhar para os espaços silenciados. 
Por fim, como muitas transformações foram realizadas a partir da mudança de governo, em dezembro de 2015, que estabeleceu como uma das prioridades do início da gestão o desmonte da LSCA, o último capítulo aborda a construção narrativa da sustentação a essas ações, articuladas a um realinhamento com a racionalidade neoliberal, além de uma sistematização das mudanças normativas e do conjunto de ações que apontam para a redução das condições para a pluralidade e diversidade de vozes no território argentino. 


\section{capítulo 1}

Comunicação e usos do território: da violência da informação a uma outra globalização 


\section{Comunicação e usos do território: da violência da informação a uma outra globalização}

No momento em que explodem as tecnologias da comunicação, nós podemos nos perguntar se elas não estão engendrando, diante de nossos olhos, monstros de um novo tipo. É certo que essas novas tecnologias são, elas mesmas, fruto da reflexão, da razão. Mas se trata de uma razão desperta? No verdadeiro sentido da palavra, isto é, atenta, vigilante, crítica, obstinadamente crítica? Ou se trata de uma razão sonolenta, adormecida, que, no momento de inventar, de criar, de imaginar, descarrilha e cria, imagina efetivamente monstros? [...] A informação não nos torna mais sabedores e sábios, a menos que ela nos aproxime das pessoas. Ora, com a possibilidade de ter acesso, à distância, a todos os documentos dos quais necessitamos, o risco de desumanização e de ignorância aumenta.

José Saramago. A quoi sert la communication? Le Monde Diplomatique (1998), trad. livre.

Um dos traços marcantes do atual período histórico é, pois, o papel verdadeiramente despótico da informação. [...] As novas condições técnicas deveriam permitir a ampliação do conhecimento do planeta, dos objetos que o formam, das sociedades que o habitam e dos homens em sua realidade intrínseca. Todavia, nas condições atuais, as técnicas da informação são principalmente utilizadas por um punhado de atores em função de seus objetivos particulares. Essas técnicas da informação (por enquanto) são apropriadas por alguns Estados e por algumas empresas, aprofundando assim os processos de criação de desigualdades.

Milton Santos, Por uma outra globalização (2000).

O período da globalização acompanha a ascensão da informação enquanto variável-chave para as dinâmicas sociais e para a organização do espaço. Essa revolução informacional, como nomeia Jean Lojkine, "não é apenas tecnológica, mas, igualmente, cultural, ética, tanto mais quanto seu eixo central é a produção, a circulação e a distribuição de informações entre todos os homens - dito de outra forma: a criação e a circulação do sentido" (LOJKINE, 2002, p. 301-302, grifo próprio). Os meios de comunicação e o sistema de mídia contemporâneo exercem um papel central na produção dos imaginários sobre o território, na circulação dos sentidos, e, por meio de uma repercussão sempre seletiva dos acontecimentos (NORA, 1976), na seleção de quais feixes de eventos 
se realizam nos lugares. Investigar a produção e a circulação de informações nesse período é, portanto, essencial para a análise dos usos atuais do território, tanto pelos agentes hegemônicos quanto pelos hegemonizados ${ }^{6}$.

As disputas e tensões entre projetos de usos do território ligados à comunicação na Argentina ganharam vigor nas últimas décadas, como em outros territórios latino-americanos. Se o fenômeno técnico (SANTOS, 2006) atual acompanha um conjunto de novas possibilidades para a comunicação, é necessário identificar as tendências predominantes de uso das novas técnicas e, também, localizar seus usos contra-hegemônicos. Concordando com Lojkine (2002, p. 149), é possível reconhecer a existência de duas concepções antagônicas sobre o uso político dessas novas tecnologias da comunicação:

de um lado, uma concepção elitista e tecnocrática, que reserva a informação estratégica a um pequeno grupo de dirigentes; de outro, uma concepção autogestionária, que visualiza, na revolução tecnológica atual, não o prolongamento de antigas tendências, mas, ao inverso, uma verdadeira revolução organizacional, que implica $\circ$ acesso de todos a todas as informações e, por consequência, o autogoverno dos homens.

Essas tensões serão exploradas nesse capítulo, com foco na formação socioespacial argentina. Vale destacar que os usos dessas possibilidades técnicas pelos agentes hegemônicos, tratando a informação como uma mercadoria e

6 Entende-se, a partir de Gramsci, a hegemonia no sentido de direção mais domínio (COSPITO, 2017, p. 639), exercido em suas duas faces - da coerção e do convencimento (RIBEIRO, 2014, p. 179). "Segundo Gramsci, a hegemonia é obtida e consolidada em embates que comportam não apenas questões vinculadas à estrutura econômica e à organização política, mas envolvem também, no plano ético-cultural, a expressão de saberes, práticas, modos de representação e modelos de autoridade que querem legitimar-se e universalizar-se. Portanto, a hegemonia não deve ser entendida nos limites de uma coerção pura e simples, pois inclui a direção cultural e o consentimento social a um universo de convicções, normas morais e regras de conduta, assim como a destruição e a superação de outras crenças e sentimentos diante da vida e do mundo [...]" (MORAES, 2010a, p. 65). Há um extenso desenvolvimento do conceito de hegemonia, baseado em Gramsci, na comunicação. Para Moraes (2010a, p. 61) “a teoria da hegemonia de Gramsci permite-nos meditar sobre o lugar crucial dos meios de comunicação na contemporaneidade, a partir da condição privilegiada de distribuidores de conteúdos". Rummert (1986), além de resgatar as origens do conceito, analisa os meios de comunicação de massa como aparelhos de hegemonia. É possível analisar, também, a composição de uma contra-hegemonia na comunicação: "um dos desafios centrais para o pensamento contra-hegemônico consiste em alargar a visibilidade pública de enfoques ideológicos que contribuam para a reorganização de repertórios, princípios, e variáveis de identificação e coesão, com vistas à alteração gradual e permanente das relações sociais e de poder" (MORAES, 2010a, p. 73). 
concentrando o poder informacional, é a tendência tratada por inúmeros autores (DANTAS, 2003; HARVEY, 2010; HEPWORTH, 1989; MATTELART, 1996, 2001; MORAES; RAMONET; SERRANO, 2013; PATERSON, 2006; RAMONET, 2010, 2013; SANTOS, 2000). Dan Schiller (1999, p. 209) lembra que esse período histórico - chamado por ele de "capitalismo digital" - fortaleceu e aprofundou flagelos da desigualdade e dominação que marcam o sistema de mercado, também na mídia. Por isso, para Lojkine (2002, p. 236-238), o desafio central da revolução informacional seria a partilha da informação.

Ao mesmo tempo em que predomina, na globalização neoliberal ${ }^{7}$, uma tendência pela união vertical dos lugares (SANTOS, 2006) - com os círculos descendentes de informações prevalecendo globalmente e nos territórios latinoamericanos (ARROYO, 2015) -, há resistências e projetos em disputa que buscam ampliar a comunicação ascendente, a partir dos lugares. A possibilidade de produzir uma outra globalização passa por ações capazes de criar condições para uma ampliação das vozes dos agentes e dos lugares. É nesse bojo que emergem as disputas por políticas que promovam a democratização da comunicação na Argentina.

Neste capítulo, analisa-se, inicialmente, a violência da informação (SANTOS, 2000) -- característica da globalização neoliberal - com foco no território argentino. É fundamental analisar o predomínio de círculos de informações descendentes, controlados por grupos empresariais altamente concentrados, aprofundando processos de monopolização ${ }^{8}$. Em seguida, busca-se

7 Referimo-nos, aqui, com Sousa Santos (2003), à globalização hegemônica, comandada a partir da razão neoliberal. Essa globalização teria como características “a preeminência do princípio do mercado sobre o princípio do Estado; a financeirização da economia mundial; a total subordinação dos interesses do trabalho aos interesses do capital; o protagonismo incondicional de empresas multinacionais; a recomposição territorial das economias e a consequente perda de peso dos espaços nacionais e das instituições que os formavam anteriormente, sobretudo os Estados nacionais; uma nova articulação entre a política e a economia, na qual os compromissos nacionais (especialmente aqueles que estabelecem as formas e níveis de solidariedade) são eliminados e substituídos por compromissos com atores globais e com atores nacionais globalizados" (SOUSA SANTOS, 2003, p. 217-218).

8 Grande parte da bibliografia sobre o tema da concentração na mídia opta pelo uso de expressões tratando de monopólios midiáticos, com o sentido da concentração monopólica dos meios de comunicação, conforme utilizado, também, neste trabalho. Venício Lima e Bráulio Araújo (2015) reconstituíram o debate sobre monopólios e oligopólios do ponto de vista do Direito Econômico, e alertam: "devemos evitar aqui uma 


\section{compreender as disputas por uma regulação democrática da comunicação no país e pela ampliação da informação ascendente.}

confusão comum: o monopólio não ocorre apenas quando uma empresa detêm 100\% do mercado, mas também quando, nas palavras de Calixto Salomão Filho, 'um dos produtores detém parcela substancial do mercado (por hipótese, mais de 50\%) e seus concorrentes são todos atomizados, de tal forma que nenhum deles tem qualquer influência sobre o preço de mercado'. [...] Seria, portanto, mais claro afirmar que há (a) monopólio quando um dos agentes econômicos possui poder de alterar unilateralmente as regras do jogo, atuando de forma independente em relação a seus concorrentes; e (b) oligopólio quando um grupo de empresas detém esse poder". Segundo Tim Wu (2012, p. 60), "na Teoria da Competição aplicada às indústrias da informação, aliás, como em qualquer outra, falamos em barreiras de entrada: os obstáculos que um recém chegado precisa superar para entrar no jogo. Mas numa indústria de informação, que comercializa um conteúdo expressivo, essas barreiras podem representar mais que uma restrição a aspirações comerciais: dependendo da forma como o meio de informação configura as comunicações numa sociedade, essas barreiras podem também coibir a livre expressão". Para este autor, "quando a mercadoria é a informação, a longevidade de um monopólio é potencialmente maior" (WU, 2012, p. 383). Para Becerra (2015, p. 19-21, tradução nossa), essa concentração pode ser definida como "um processo que se refere à incidência das maiores empresas de uma atividade econômica em sua cadeia de valor: quanto maior a presença de uma empresa, menor a incidência do resto. Em um crescente processo de concentração, há cada vez menos empresas que controlam a maior parte do volume total de um mercado. Nesta perspectiva, o extremo ao qual os processos de concentração podem conduzir é à tendência dos mercados de configurar oligopólios ou monopólios, onde uma ou algumas grandes empresas ocupam todo o mercado, reduzindo assim as opções disponíveis. A subordinação de um conjunto de atores à predominância de uns poucos produzem um círculo que se retroalimenta, incrementando a força desses poucos que captam os melhores recursos do setor; portanto, um dos efeitos da concentração é que reduz o significado do restante dos atores desse setor de atividade [...] No caso das atividades ligadas à comunicação, à informação e à cultura, os processos de concentração apresentam um duplo significado, porque a situação econômica deve ser somada à importância simbólica dos bens imateriais que essas atividades produzem". 


\subsection{Globalização, violência da informação e os monopólios midiáticos na formação socioespacial argentina}

Na indústria da comunicação, há um número relativamente pequeno de corporações predominantes, as quais integram todos os aspectos da produção e distribuição e que são baseadas nos principais países desenvolvidos e tornaram-se transnacionais em suas operações. [...] Algumas restrições nesse processo de concentração de recursos podem ser de interesse público.

UNESCO. Relatório MacBride (1980).

Em 1983, os homens e mulheres que dirigiam as 50 corporações de mídia predominantes nos Estados Unidos caberiam confortavelmente em um salão de hotel modesto. [...] Por volta de 2003, cinco homens controlavam todas as mídias que pertenciam às cinquenta corporações vinte anos antes. Esses cinco, proprietários de outras corporações digitais, agora caberiam em uma grande cabine telefônica.

Ben Bagdikian, The New Media Monopoly (2004), trad. livre.

A monopolização da comunicação representa um problema histórico para toda a América Latina. Segundo Arroyo (2004, p. 65), a convergência entre território, mercado e Estado na América Latina foi marcada, internamente, pela concentração (social e regional) das riquezas, o que também é válido para o setor de comunicações. Essa situação é acentuada por duas importantes peculiaridades históricas da região: "o fato de a concentração latino-americana ser liderada por reduzido número de grupos familiares [... e] o fato de, ao longo da instável história política da região, muitos desses grupos terem promovido a propaganda de ações golpistas que levaram à ruptura de sistemas democráticos" (BEZERRA, 2012, p. 132). Na América Latina, essa concentração empresarial, reduzida a poucas famílias ${ }^{9}$, evidencia um caráter patrimonial. Tomando o caso

9 Cinco famílias comandam os principais conglomerados latino-americanos: “a família do venezuelano Gustavo Cisneros, proprietário das emissoras de televisao Univisión, DirectTV, Chilevisión e Venevisión; dos mexicanos Emilio Azcárraga Jean e Carlos Slim Helú, donos da Televisa; da argentina Ernestina Herrera, titular do grupo Clarín; dos irmãos Marinho, do grupo brasileiro O Globo e, por fim, do mexicano Angel González, proprietário de quatro canais de televisão na Nicarágua, a Red TV Chile e dois no Peru" (ULLOA apud BEZERRA, 2012). Entre as famílias proprietárias de meios de comunicação, estão: Marinho, Macedo, Frias, Mesquita, Sirotsky, Saad, Abravanel e Civita (Brasil) (INTERVOZES, 2017b); "Cisneiros e Zuloaga (Venezuela); Noble, Saguier, Mitre, Fontevecchia e Vigil (Argentina); Slim e Azcárraga (México); Edwards, Claro e Mosciatti (Chile); Rivero, Monastérios, Daher, Carrasco, Dueri e Tapia (Bolívia); Ardila Lulle, Santo Domingo e Santos (Colômbia) [...] No Equador, 19 famílias controlam 298 das 348 frequências de televisão" (MORAES, 2011, p. 40). 
argentino, o principal conglomerado de comunicação do país, o Grupo Clarín, da família Noble, deu apoio editorial e participou da construção da narrativa para o golpe de Estado de 1976 (BORRELLI, 2012) que culminou em um violentíssimo processo ditatorial que suprimiu direitos humanos, perseguiu, torturou e assassinou opositores e impôs grave censura. Posteriormente, o mesmo grupo foi beneficiado em seus negócios a partir da ação coordenada com a ditadura (TÉLAM, 2015).

Uma das características mais marcantes da formação socioespacial argentina no que se refere à comunicação, segundo Marino, Mastrini e Becerra (2010, p. 5), é a concentração em conglomerados atuantes em múltiplos setores. O principal grupo, Clarín, se constituiu com posse de emissoras de televisão aberta, sinais e empresas de TV por assinatura, estações de rádio, jornais e fábrica de papel para jornais, portais na internet entre outras atividades relacionadas. Outras características apontadas pelos autores são o índice altíssimo de concentração dos meios de maior alcance e a concentração geográfica da produção midiática na região de Buenos Aires. As condições normativas para essa organização da comunicação no território argentino estavam baseadas em uma lei — n. 22.285/80 - que fora sancionada durante a ditadura militar (19761983) e que desenhou um sistema de comunicação centralizador e privatista (MARINO; MASTRINI; BECERRA, 2010). Esse marco normativo esteve vigente até 2009.

A concentração da propriedade e a centralização da produção de conteúdos não é uma exclusividade dos agentes midiáticos nacionais dos países latino-americanos. Moraes (2010b, p. 193) alerta que, no paradigma neoliberal que marca o período da globalização, consolidaram-se megagrupos de comunicação, sediados sobretudo nos países do centro do sistema capitalista. Para o autor, convivemos com "uma abundância de dados, sons e imagens que se originam, na maior parte das vezes, de fontes de emissão controladas por superempresas que se movimentam pela Terra sem prestar contas a ninguém, exceto a seus 
acionistas" (MORAES, 2010b, p. 208). Assim, segundo este autor, a mídia global

está nas mãos de duas dezenas de conglomerados, com receitas entre US\$ 5 bilhões e US\$ 35 bilhões. Eles veiculam dois terços das informações e dos conteúdos culturais disponíveis no planeta. Entrelaçam a propriedade de estúdios, produtoras, distribuidoras e exibidoras de filmes, gravadoras de discos, editoras, parques de diversões, TVs abertas e pagas, emissoras de rádio, revistas, jornais, serviços online, portais e provedores de internet, vídeos, videogames, jogos, softwares, CD-ROMs, DVDs, equipes esportivas, megastores, agências de publicidade e marketing, telefonia celular, telecomunicações, transmissão de dados, agências de notícias e casas de espetáculos (MORAES, 2010b, p. 198-199).

Na escala global, além dos conglomerados citados, há três agências transnacionais de notícias - Reuters, France-Presse e Associated Press - que comandam uma parcela muito expressiva das notícias que circulam no mundo e pautam as mídias nacionais (AGUIAR, 2010; NABARRO; SILVA, 2012; PASTI, 2013a). A constituição, nesse período, de um sistema de objetos técnicos funcionais à fluidez global da informação favoreceu a ampliação da atuação dessas agências, configurando os círculos descendentes que atingem verticalmente os territórios. Assim, as agências reorganizam sua atuação, mantêm as hierarquias territoriais do comando da notícia, aprofundam a dependência dos veículos de comunicação nacional em relação às suas informações e são produtoras da globalização como a conhecemos (PASTI, 2013a, p. 150).

Fato é que as novas tecnologias da informação e da comunicação que viabilizam a comunicação global estão apropriadas por empresas, corporações ou conglomerados, como empreendimentos capitalistas articulados com grupos, classes ou blocos de poder predominantes em escala nacional ou mundial, como aponta Ianni (1999, p. 22), para quem

o que singulariza a grande corporação da mídia é que ela realiza limpidamente a metamorfose da mercadoria em ideologia, do mercado em democracia, do consumismo em cidadania. Realiza limpidamente as principais implicações da indústria cultural, combinando a produção e a reprodução cultural com a 
produção e reprodução do capital; e operando decisivamente na formação de “mentes" e "corações", em escala global (IANNI, 1999, p. 17).

Nas últimas décadas do século XX, esses agentes globais ampliaram ainda mais a presença de suas informações, imagens e discursos nos conglomerados nacionais de mídia da América Latina. Ainda em 1990, o jornalista argentino Guillermo Piernes alertava para a dependência de conteúdos desses conglomerados e agências nas mídias nacionais latinoamericanas (PIERNES, 1990, p. 60). Na década de 1990, intensificou-se a concentração dos meios em atuação no território argentino, quando as políticas de comunicação materializaram uma forte concentração do capital, uma desnacionalização parcial da propriedade e a expansão dos mercados publicitários (MASTRINI; LORETI, 2009, p. 62).

Ao analisar esse fenômeno, Milton Santos (2000, p. 38) afirma que uma característica central do atual período é a violência da informação - já que a informação, embora cada vez mais essencial à vida social e econômica, tem seu comando centralizado em poucos agentes, sobretudo grandes empresas globais. Esses agentes possuem imenso poder de produzir e fazer circular discursos e sentidos de acordo com seus interesses. Para este autor, é preciso considerar o caráter cada vez mais ideológico que possuem essas informações, a relação "carnal" entre a produção de notícias e a publicidade, e a facilidade da produção de falsidades, fábulas e mitos a partir da distorção dos fatos pelos poucos agentes controladores da informação (SANTOS, 2000, p. 40).

No mesmo sentido, Nora (1976, p. 187) afirma que estaríamos em um estado de "superinformação perpétua" e de "subinformação crônica". O que o autor pretende explicitar é que há um "excesso" quantitativo de informações circulando no território mas que, devido à ação dos grandes meios e à monopolização da informação, temos dificuldade em saber o que efetivamente acontece nos lugares. A informação que circula sobre o que acontece não vem da interação entre as pessoas, mas do que é veiculado pela mídia, com uma 
interpretação interessada dos acontecimentos (SANTOS, 2000, p. 41). Essa interpretação tende à homogeneizar-se em função de grande parte das informações e imagens sobre o mundo partirem dos mesmos agentes.

Esse estado de "superinformação perpétua e subinformação crônica" é tratado, com diferentes abordagens, por diversos autores do campo da comunicação. Ramonet (2010) considera que essa situação corresponde a uma nova forma de "censura", que ele denomina como "censura democrática". Esta, "em oposição à censura autocrática, não se funda mais na supressão ou no corte, na amputação ou na proibição de dados, mas na acumulação, na saturação, no excesso e na superabundância de informações" (RAMONET, 2010, p. 28). Para Menezes (2005), a atual velocidade na transmissão de dados gera um excesso de informações e, paradoxalmente, favorece a incomunicação. Na mesma linha, Serrano (2013, p. 177) afirma que a sobrecarga de informação já demonstrou ser uma das formas mais efetivas de ter um povo desinformado. Moretzsohn (2002, p. 150-151) comparou essa superinformação esvaziada à "cegueira branca" - por excesso de luz - do primoroso romance de José Saramago, O ensaio sobre a cegueira ${ }^{10}$.

Dialogando com a proposta de Ramonet, Palma (2014) questiona: quem realiza, hoje, essas novas formas de censura? Para o autor, está claro que, com o imenso poder dos meios concentrados, esses poucos megagrupos são os responsáveis pelo controle efetivo dos fluxos de informações e por essas novas formas, mais complexas, de censura. A concentração da propriedade já pressupõe uma censura encoberta, pelo controle do mercado de trabalho (que dificulta as dissidências), pela imposição da linha editorial dominante e pela possibilidade desses grupos de sufocar as opiniões distintas, seja pelo controle dos meios, do financiamento ou da publicidade que poderiam viabilizar outras vozes (PALMA, 2014, p. 29). Conforme Gómez (2013, p. 47),

10 "Agora [...] ei-lo que se encontrava mergulhado numa brancura tão luminosa, tão total, que devorava, mais do que absorvia, não só as cores, mas as próprias coisas e seres, tornando-os, por essa maneira, duplamente invisíveis" (SARAMAGO, 2009, p. 16). 
a concentração de meios é antidemocrática não só porque supõe uma limitação à pluralidade de opiniões e informações em função dos conteúdos desses meios serem homogêneos e não diversos; também pressupõe que esses atores, tornados oligopólicos ou monopólicos, utilizam seu poder para prejudicar ou impedir a entrada de novos operadores que possam competir com seu status, reduzindo, assim, as possibilidades de informações e opiniões às quais a população do país tem acesso.

Esse controle e restrição das informações em circulação compõem a violência da informação que caracteriza a globalização. Conforme Silva (2012), há a conformação de importantes círculos globais da informação, retratando o crescente poder das empresas globais sobre o destino dos territórios, da sociedade e da política. Martín-Barbero (2010, p. 62-63) alerta que a atuação das corporações midiáticas acompanha profundas transformações na cultura cotidiana das maiorias.

No território argentino, o projeto neoliberal de inserção passiva à globalização (BRANDÃO, 2007) na década de 1990 implicou um conjunto de privatizações e uma profunda transformação na estrutura dos mercados de meios de comunicação e telecomunicações no país (MASTRINI; BECERRA, 2006, p. 78). Conforme Silveira (2005, p. 186), nesse período a remodelação da base material foi significativa e amparada num novo arcabouço normativo: “concessões, privatizações e abundantes subsídios públicos confundiam-se nos investimentos em infraestruturas viárias e infoviárias, telecomunicações, energia, petróleo e gás". As privatizações englobaram canais de televisão, estações de rádio e a empresa monopólica de telefonia. Como resultado, houve maior concentração ${ }^{11}$ no setor e formação de grandes grupos midiáticos privados. Esses grupos concentrados de meios construíram uma articulação eficiente com

"Harvey (2010, p. 144), questiona: “Mas por que, num mundo neoliberal onde os mercados competitivos supostamente são dominantes, qualquer tipo de monopólio seria tolerado, quem sabe até visto como desejável?". Segundo ele, "a competição, como Marx observou, tende sempre ao monopólio (ou oligopólio), simplesmente porque a sobrevivência do mais apto na guerra de todos contra todos elimina as empresas mais fracas. Quanto mais feroz a competição, mais veloz a tendência ao oligopólio, para não dizer monopólio. Portanto não é por acidente que a liberalização dos mercados e a celebração da competição nos últimos anos produziram uma incrível centralização de capital." (HARVEY, 2010, p. 144-145). 
o poder político. Um dos indicadores disso foi a escassa regulação do setor, para atender aos interesses dos que controlam a propriedade dos meios (BECERRA, 2014).

Analisando a situação da comunicação argentina na primeira metade da década de 2000, Becerra e Mastrini (2009) identificaram os principais grupos constituídos no país: Clarín (que possuia uma ampla gama de interesses, liderando mercados de imprensa escrita, televisão a cabo, televisão aberta, rádio e agências de notícias, entre muitos outros), Telefónica (atuando, então, em telecomunicações e televisão aberta, sendo importante operador de rádio até 2004, quando vendeu sua operação ao grupo Prisa), Vila-Manzano-De Narváez (em televisão a cabo, televisão aberta e imprensa, entre outros) e Hadad (rádio, televisão aberta e imprensa escrita).

Ao observar a concentração do mercado de mídia em 2004 nos quatro principais operadores de cada setor (1), pode-se perceber a concentração média nas comunicações superior a 80\% sob controle desses grupos.

\section{Figura 1: Concentração de mercado nos 4 principais operadores - Argentina - 2004}

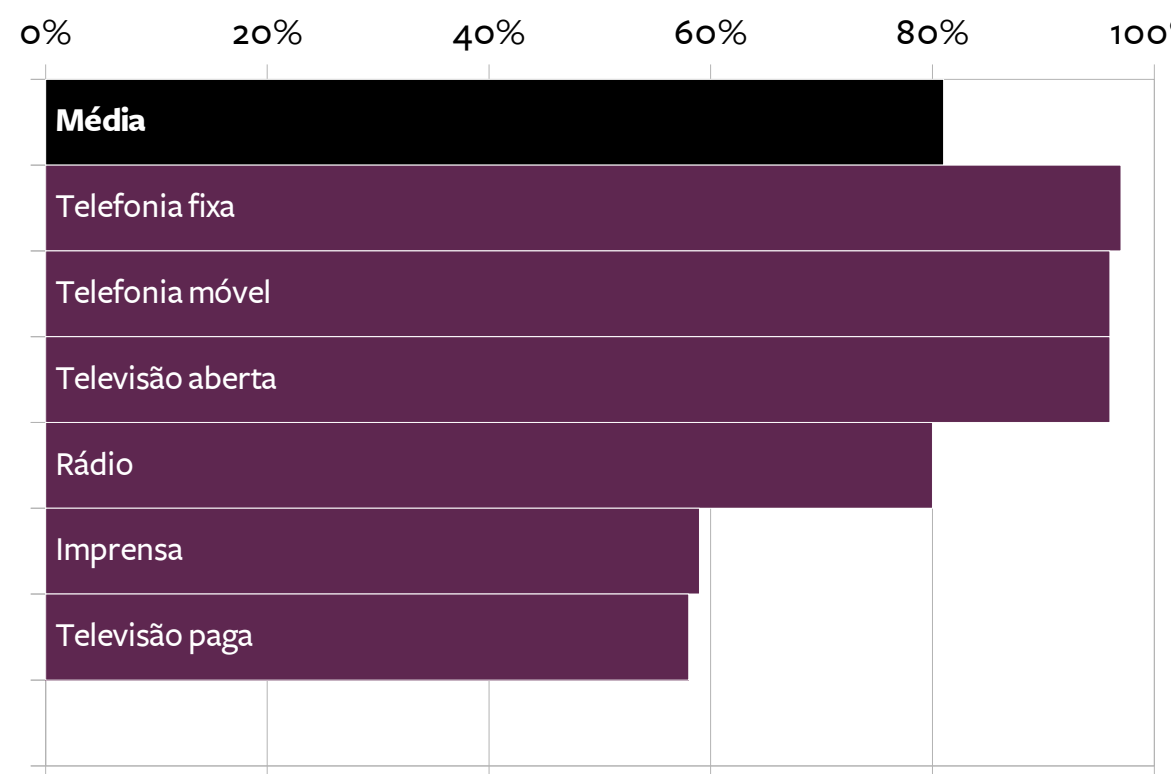

Fonte: elaboração própria a partir de Becerra e Mastrini (2017a). O índice utilizado é o CR-4, que indica a concentração de mercado nos quatro principais operadores de cada mercado, medido de 0 a 1.

Em 2008, os seis maiores grupos de comunicação (Clarín, Telefónica, 
América Multimedios - associada ao Vila-Manzano -, Hadad, La Nación e HMT\&F) controlavam ou tinham participação acionária em cerca de 200 veículos de comunicação (CALCAGNO, 2008; MORAES, 2011). No caso da TV aberta, Clarín, Telefónica e América possuíam 60\% das concessões públicas nessa data. $O$ Grupo Clarín já atuava (e segue atuando) em praticamente todos os mercados culturais. Ele exerce uma posição dominante que facilita sua interlocução privilegiada com os grandes anunciantes publicitários e seu acesso direto às fontes de poder (econômico, político, sindical etc.) (BECERRA; MASTRINI, 2009, p. 74). Em 2008, os dados da concentração nos principais operadores seguiram apontando para uma intensa concentração nos mercados de mídia impressa, radiodifusão, telecomunicações e internet (2).

Figura 2: Concentração de mercado nos 4 principais operadores - Argentina - 2008

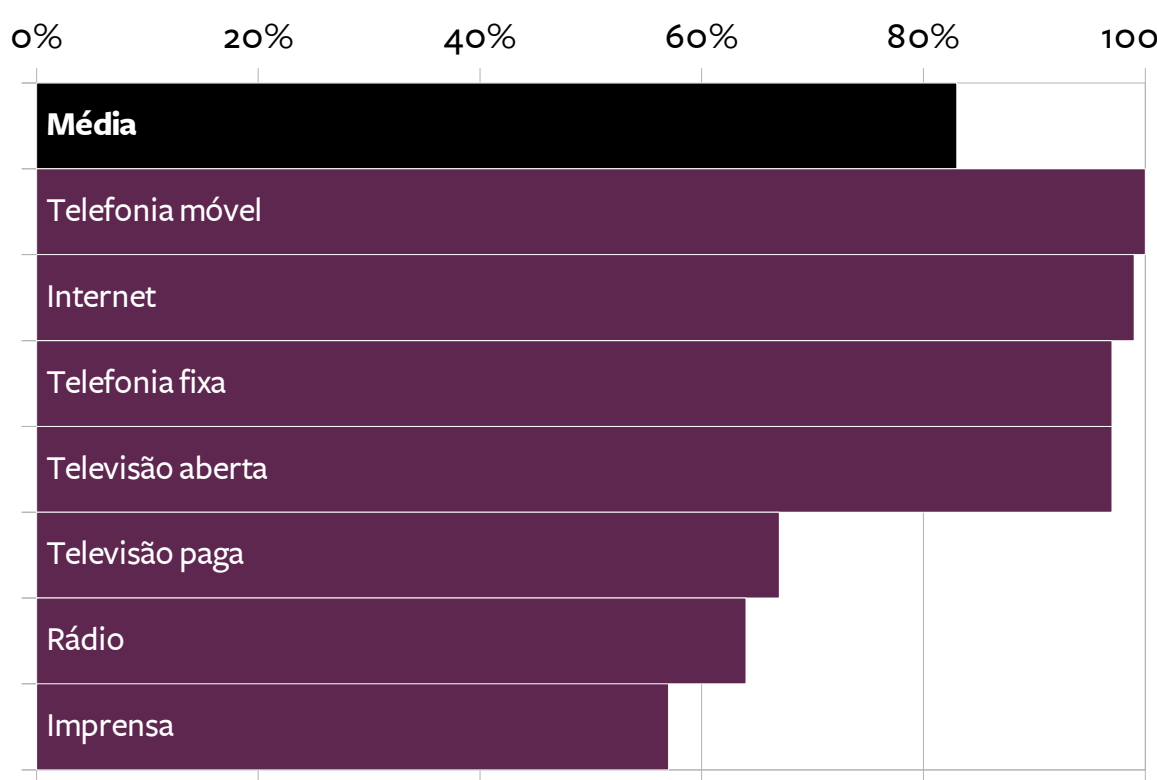

Elaboração própria, a partir de Becerra e Mastrini (2017a). O índice utilizado é o CR-4, que indica a concentração de mercado nos quatro principais operadores de cada mercado, medido de 0 a 1.

A concentração da propriedade em poucos grupos tende à unificação da linha editorial e à redução da diversidade e pluralidade de discursos em circulação, como notou Becerra (2014, p. 64). Outra consequência importante apontada por este autor é a concentração geográfica da produção de conteúdos e informações. Essa concentração usualmente se dá 
nos lugares sede dos principais grupos (Buenos Aires, na Argentina; São Paulo e Rio de Janeiro, no Brasil; Santiago, no Chile; Montevidéu, no Uruguai; Lima, no Peru; Caracas, na Venezuela; e o Distrito Federal no México). Este impacto também empobrece a apresentação de distintas versões do real por parte do público/leitores, e condena a uma sub-representação vastos setores que habitam o "interior" dos países (BECERRA, 2014, p. 65).

A concentração geográfica da produção de informações permanece bastante significativa na maior parte dos países da América Latina ${ }^{12}$. No caso argentino, a parte da produção da indústria cultural se concentrou desde o início do século XX até a atualidade na cidade de Buenos Aires (ITURRALDE, 2015, p. 170; MASTRINI; BECERRA, 2006, p. 77). Isso reflete uma construção histórica da formação socioespacial argentina (SILVEIRA, 1999a, 2005) em que Buenos Aires desponta como espaço luminoso da globalização ${ }^{13}$ - concentrando maiores densidades técnicas e informacionais (SANTOS; SILVEIRA, 2001). Segundo Mastrini e Becerra (2006), nas décadas de 1940 e 1950, acelerou-se a migração do campo para os centros urbanos, com uma forte concentração no entorno de Buenos Aires. A Área Metropolitana de Buenos Aires (AMBA) concentra um terço da população do país e torna-se um centro de referência política, econômica e cultural.

As transformações da metrópole de Buenos Aires nos anos 1990 estiveram ligadas à expansão dos fluxos financeiros e a produção de novos objetos urbanos vinculados à globalização (CICCOLELLA, 1999), que acompanharam um processo que tem como chaves, ao mesmo tempo,

12 Levantamento recente sobre o caso brasileiro identificou a permanência dessa intensa concentração das sedes dos principais veículos ou redes de comunicação e dos maiores grupos midiáticos nas duas cidades mencionadas - São Paulo e Rio de Janeiro (INTERVOZES, 2017b). Essa concentração é acentuada pelo predomínio do sistema de emissoras afiliadas, que subordina as concessões locais e regionais ao conteúdo e lógica dos grandes grupos. A respeito da organização da rede do Grupo Globo no território brasileiro e o papel subordinado das emissoras locais, conferir Munhóz (2008). A regionalização midiática do território brasileiro é analisada com profundidade por Aguiar Lopes (2016) e Pinto (2017).

13 "Chamaremos de espaços luminosos aqueles que mais acumulam densidades técnicas e informacionais, ficando assim mais aptos a atrair atividades com maior conteúdo em capital, tecnologia e organização. Por oposição, subespaços onde tais características estão ausentes seriam os espaços opacos. Entre esses extremos haveria toda uma gama de situações. Os espaços luminosos [...] seriam os mais suscetíveis de participar de regularidades de uma lógica obediente aos interesses das maiores empresas", afirmam Santos e Silveira (2001, p. 264). 
modernidade e pobreza (SILVEIRA, 2016). Para Ciccolella e Vecslir (2012, p. 38), a concentração de fatores e artefatos da globalização foi uma constante nos anos 1990 e 2000, adotando e favorecendo mais ou menos os mesmos segmentos territoriais e atores. Essa concentração intensa permite falar em uma macrocefalia (VAPNARSKY, 1995), onde a cidade de Buenos Aires desempenha um papel chave por abrigar, conforme Parserisas (2016, p. 105), uma diversidade de divisões territoriais do trabalho que a fazem complexa e atrativa pra o desenvolvimento de atividades econômicas de maior grau de capital, tecnologia e organização. Conforme Silveira (1999a, p. 416),

\begin{abstract}
a cidade de Buenos Aires afirma-se como coração do movimento financeiro e dos níveis superiores dos sistemas de saúde, educação, lazer e publicidade do país. Ela sedia, outrossim, os escritórios das mais poderosas firmas nacionais e das filiais das firmas globais, ao passo que elabora e concentra a maior parcela das informações sobre a economia, a sociedade e o território.
\end{abstract}

Por meio do comando dos fluxos de informação, a metrópole de Buenos Aires se faz presente em todo o território argentino (SILVEIRA, 1999a, p. 217). As demais localidades configuram-se com um papel marcado pela recepção das informações de Buenos Aires, com pouca produção própria. Com exceção de sete cidades maiores do interior, quase a totalidade das localidades conta apenas com um sinal de televisão aberta (LORETI; LOZANO, 2014, p. 164). Ao observar dados da produção audiovisual da televisão aberta no interior do país (3), nota-se que as televisões das províncias são, sobretudo, retransmissoras de conteúdos da região metropolitana de Buenos Aires. 


\section{Figura 3: Origem da produção dos conteúdos da TV aberta - Províncias (2011)}

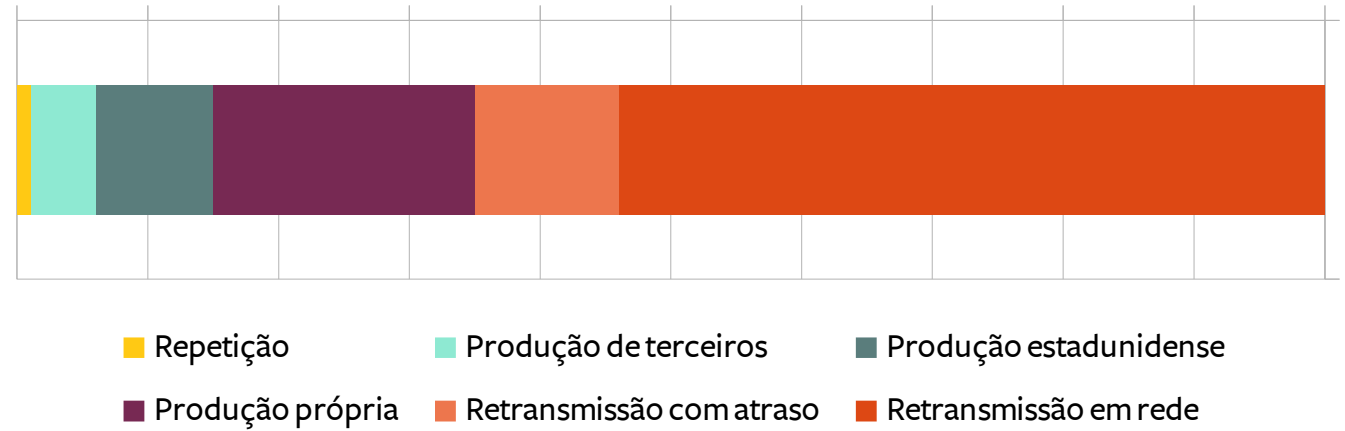

Fonte: Elaboração própria, com base em Loreti e Lozano (2014).

A retransmissão, nas províncias, atingia 65\% do total de programação. Já a metrópole de Buenos Aires configura-se como centro de produção do audiovisual do país (4) - produção que está concentrada nas mãos de poucas empresas (LORETI; LOZANO, 2014, p. 165).

\section{Figura 4: Origem da produção de conteúdos da TV aberta - região metropolitana de Buenos} Aires (2011)

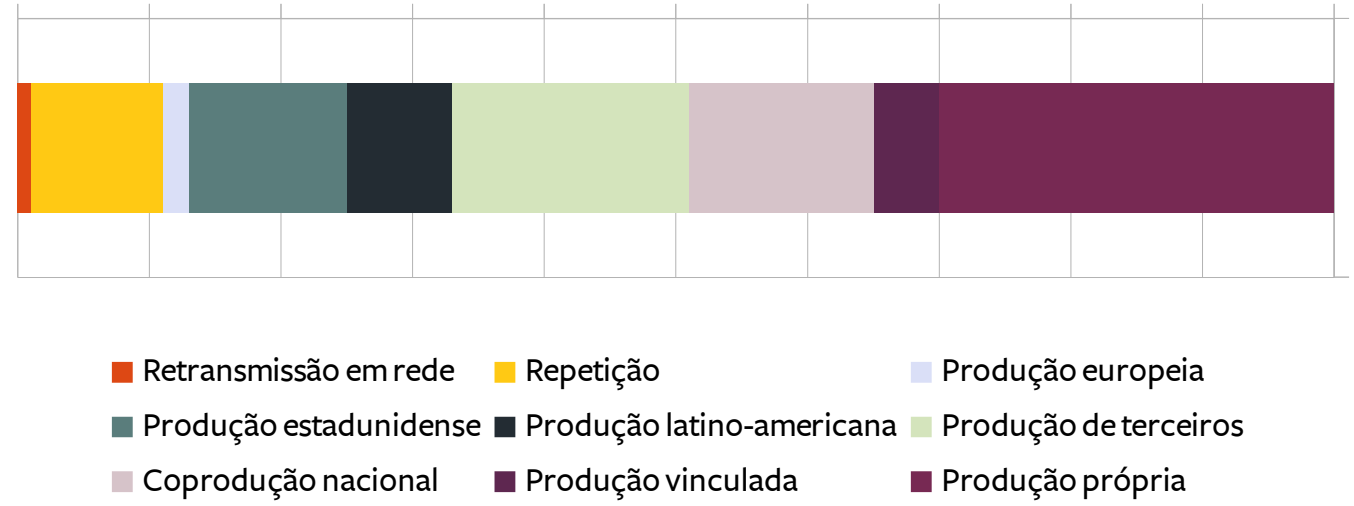

Fonte: Elaboração própria, com base em Loreti e Lozano (2014).

Observa-se que os conteúdos da televisão em Buenos Aires estavam marcados por um predomínio da produção própria, vinculada e coproduções (49\%), com mínima retransmissão (1\%). Trata-se, portanto, de uma grande diferenciação no território, com a metrópole de Buenos Aires exercendo o comando nacional da produção e circulação do audiovisual. 
Dialogando com os conceitos de espaços luminosos e opacos da globalização, Rojas (2014, p. 151) sugere o entendimento de que os espaços opacos são espaços "silenciosos" ou espaços "do silêncio". Romper com a violência da informação seria ampliar o alcance das vozes desses espaços, criando condições para a ampliação da densidade comunicacional (SANTOS, 2006, p. 257) dos lugares.

Entende-se, aqui, que políticas de comunicação podem transformar as condições normativas, técnicas e de organização de modo a ampliar a densidade comunicacional dos lugares. Rojas recomenda que os projetos voltados aos espaços com dinâmicas lentas e silenciosas sejam cuidadosos, feitos "quase 'à mão', com base em iniciativas de governos e outros atores, com apoio extraterritorial e de múltiplas experiências internacionais, que contemplem a esperada participação cidadã" (ROJAS, 2015, p. 224-225). Discute-se, adiante, como se dá a disputa de projetos que buscam criar essas condições, para a comunicação, no território argentino.

Para a resistência à violência da informação, cabe compreender que a disputa central para um projeto de comunicação mais democrática hoje se dá no combate ao poder monopólico das corporações. Para Palma (2014, p. 31), em repúblicas democráticas como a Argentina, os principais adversários da informação seriam, hoje, essas corporações midiáticas. A agenda de combate aos monopólios engloba um conjunto de políticas e normas com a intenção de modificar o status quo das indústrias de comunicação e cultura: notavelmente, trata-se de políticas que pretendem alterar o regime de propriedade, os modos de financiamento e as possibilidades de acesso a elas por parte de diferentes atores sociais (BECERRA, 2014, p. 67).

A agenda construída historicamente em torno da democratização da comunicação é uma arena de disputas de significados e concepções sobre os agentes, políticas e ações que promoveriam as condições para uma comunicação mais democrática. A efetividade dessa agenda exige um olhar geográfico, 
buscando compreender as dinâmicas de centralização e descentralização do comando dos fluxos de informação, bem como questões de acesso, de produção e circulação de informações e sentidos a partir do território.

Para uma leitura geográfica da democratização da comunicação, cabe recuperar o entendimento do espaço banal. Milton Santos defende uma análise espacial baseada na totalidade e no espaço banal, em oposição às análises territoriais econômicas dos pontos estratégicos, do espaço econômico, que analisa apenas o que interessa às grandes empresas: "preferimos partir da noção de espaço banal, espaço de todas as pessoas, de todas as empresas e de todas as instituições" (SANTOS, 2006, p. 191).

A democratização da comunicação deve partir desse espaço banal, de todos os agentes, olhando para a totalidade do território. Como afirma Santos (2000, p. 174), “se a realização da história, a partir dos vetores 'de cima', é ainda dominante, a realização de uma outra história a partir dos vetores 'de baixo' é tornada possível. E, para isso contribuirão, em todos os países, a mistura de povos, raças, culturas, religiões, gostos etc.". Promover condições para a ampliação da comunicação ascendente seria, portanto, essencial para a agenda da democratização da comunicação no território, fazendo frente ao predomínio dos círculos descendentes de informações, comandados pelos grandes grupos de comunicação.

Compreender a complexidade dessas desigualdades territoriais que constituem, historicamente, cada formação socioespacial (SANTOS, 1977) e sua diversidade regional é fundamental para pensar um planejamento territorial democrático e, em particular, a democratização da comunicação. Ampliar a capacidade de "fala" e de "escuta" dos lugares passa por transformar as condições materiais e imateriais, técnicas e normativas dos lugares.

No entanto, como conta Mattelart (2005, p. 146), os grandes grupos de comunicação não estão muito dispostos a ver publicamente tratada a questão da diversidade no espaço midiático. Abordá-la implica debater o tema da censura 
econômica no contexto da concentração do setor. Assim, apesar da evidente monopolização da informação na América Latina, as grandes empresas de comunicação, temendo perder vantagens econômicas e influência na conformação do imaginário social (MORAES, 2017, p. 40), têm obstaculizado as demandas por novas regulamentações da comunicação (MARINGONI; GLASS, 2012). Essas empresas alegam que a pretensão dos que advogam a criação de novas normas é implantar "a censura e o cerceamento à livre circulação de ideias", como será visto adiante. Desse modo, acentuam-se os conflitos em torno das normas para regular a comunicação e condicionar as dinâmicas comunicacionais nesses territórios. 


\subsection{A psicosfera e as disputas por uma regulação democrática da comunicação na Argentina}

Señores, este Grupo está em peligro de perder muchas de sus posiciones. Y mucho dinero. Si eso sucede, la mayoría de ustedes tendrán que ser despedidos o sus sueldos reducidos más que considerablemente. Ahora saben qué tienen que hacer y, sobre todo, qué tienen que decir. Buenas noches.

Diretor do Clarín a seus jornalistas "estrelas", sobre a Ley de Medios. Relato presente em Feinmann (2013).

Se a tal liberdade de imprensa não vale nem para profissionais de imprensa, então ela vale para quem? Quem é o sujeito dessa liberdade de imprensa? Não somos nós, o público. Não são as jornalistas. Não são nem as celebridades, aparentemente. Sobram apenas a meia dúzia de famílias que é dona de quase todos os meios de comunicação em nosso país. A liberdade de imprensa só é realmente garantida aos proprietários da imprensa.

Alex Castro, Elogio à liberdade de expressão (2015).

Para analisar as transformações em curso na organização da comunicação no território argentino, é vital recuperar a compreensão do espaço geográfico como um campo permanente de conflitos e de disputas de projetos da sociedade (ISNARD, 1978, 1982). Se, de um lado, a monopolização da informação configura-se enquanto tendência e projeto dominante na globalização neoliberal, atendendo aos interesses dos agentes econômicos hegemônicos, há um conjunto de resistências, de clamores por outras possibilidades de comunicação - que, na Argentina, conseguiu compor um importante campo de forças políticas com incidência na organização do território.

O enfrentamento à violência da informação e a consequente reorganização da comunicação não se refere apenas a constituir um novo conjunto de materialidades. À dimensão dos objetos técnicos ou fabricados do espaço, associa-se uma dimensão - nem sempre coincidente - de imaginários, sentidos, emoções e valores. Chamamos a primeira, com Santos (2006), de tecnosfera e a segunda, de psicosfera. Para este autor, a psicosfera diz respeito ao reino das ideias, crenças, paixões e lugar da produção de um sentido (SANTOS, 
2006, p. 256), enquanto a tecnosfera compreende o conjunto de objetos técnicos, resultado da artificialização crescente do espaço (SANTOS, 2008b, p. 30).

Os usos do território se fazem conjuntamente na tecnosfera e na psicosfera, que são indissociáveis, complementares e os dois pilares da racionalidade fundadora da globalização (PEREIRA, 2007, p. 48). Para Kahil (2010, p. 477), a esfera dos objetos técnicos não tem valor ou significado em si. Como tanto a tecnosfera quanto a psicosfera são frutos do artifício, são subordinadas aos que impõem as mudanças (SANTOS, 2008b, p. 30). Investiga-se, neste trabalho, as duas dimensões.

Por vezes, a difusão de uma psicosfera antecede a transformação da tecnosfera. A psicosfera difundida na globalização, segundo Ribeiro (1991, p. 48), "produz a busca social da técnica e a adequação comportamental à interação moderna entre tecnologia e valores sociais". Os sentidos em circulação na psicosfera estão associados ao espírito de uma época, segundo Kahil (2010, p. 477) ${ }^{14}$. Daí a importância da difusão de discursos e valores que sustentam e acompanham o processo de globalização neoliberal na América Latina - como visto em Tozi (2005, p. 75-82) no caso das privatizações no território brasileiro. E, também, a importância da produção de uma outra psicosfera ${ }^{15}$ para e com a ascensão dos movimentos antineoliberais nos territórios latino-americanos. Segundo Moraes (2011), um dos desafios centrais para o pensamento contrahegemônico é alargar a compreensão pública sobre a necessidade de se transformarem, gradual e permanentemente, as relações sociais de poder. Para este autor,

a pluralização da comunicação depende, entre outros requisitos, do

${ }^{14}$ Kahil menciona esse "espírito de uma época" como Zeitgeist. Resgatando essa categoria filosófica, Inwood (1997, p. 119) afirma que Hegel prefere chamá-lo de um "Geist der Zeit" — espírito da época, do tempo — que corresponde à noção de que "a mentalidade, a vida social e produtos culturais de uma dada época, especialmente no seio de um determinado povo, compartilham um espírito comum".

15 O sentido original do termo psicosfera remonta ao conjunto de sentidos e valores subordinados aos que impõem as mudanças, aos agentes hegemônicos, no contexto de uma leitura crítica da globalização (SANTOS, 2000, 2006). Discute-se, neste trabalho, a produção de uma "outra" psicosfera, a partir das disputas de sentidos dos projetos contra-hegemônicos de comunicação aqui investigados.

58 | Comunicação e usos do território: da violência da informação a uma outra globalização 
convencimento social sobre a necessidade de espaços mais livres de informação e opinião e, principalmente, de políticas públicas que promovama diversificação de fontes emissoras e a multiplicação dos pontos de vista. (MORAES, 2011, p. 49)

A mídia exerce um papel fundamental na difusão dos sentidos, na produção da psicosfera e na realização efetiva dos eventos no território. Nora (1976, p. 181-182) fala de uma produção do acontecimento pelos agentes produtores de informação e de um monopólio da história por parte dos meios de comunicação de massa. Para ele, no atual período histórico, os acontecimentos só marcam sua presença por intermédio desses meios de comunicação - a mídia é a condição de sua existência. Discutindo a televisão na era da comunicação global, Gurevitch (apud IANNI, 1999, p. 16) também notava a emergência da mídia como um participante ativo nos eventos que ela empenhadamente "cobre". Portanto, há um grande desafio quando se pretende fazer circular sentidos contrários aos interesses dos monopólios da informação na psicosfera.

O combate aos monopólios midiáticos não é novo. Segundo Mattelart (2001, p. 202), os primeiros sinais de uma reflexão crítica consequente sobre a ordem de representação do mundo oriunda do centro do sistema capitalista vieram da América Latina. De um lado, crescia a percepção de que, "quase cinco séculos depois da chegada dos europeus ao continente os povos dos países latino-americanos pouco intercambiam em matéria de informação, de cultura" (PIERNES, 1990). De outro, na América Latina, criticava-se o domínio da indústria cultural dos países capitalistas centrais - em obras como a de Ianni (1979) e o clássico de Dorfman e Mattelart (2010).

Assim, entre as décadas de 1960 e 1980, ganhou força um questionamento, a partir de países latino-americanos (MELO, 2008) e outras nações do Sul, sobre sua dependência em relação às agências de notícias dos países capitalistas centrais. Esse questionamento foi um dos temas centrais da UNESCO na época (MATTELART, 2002). Esses então chamados "países não- 
alinhados" - um grupo de países subdesenvolvidos, organizados no Movimento dos Não-Alinhados (MNA) - consideravam que uma estrutura de poder transnacional centralizada nas grandes agências se instalara, por meio da qual os países centrais perpetuavam sua influência mundial e impunham seus valores e aspirações (PÁZ REBOLLO, 1999, p. 124). Sendo assim, os "não-alinhados" passaram a clamar por uma Nova Ordem Mundial da Informação e da Comunicação (NOMIC) ${ }^{16}$. Foram realizados vários debates da NOMIC em eventos internacionais de instituições como a UNESCO e a ONU (Quadro 1).

\section{Quadro 1: Eventos globais sobre a NOMIC nos âmbitos da ONU, UNESCO e MNA - 1973 a 1980}

\begin{tabular}{|c|c|c|c|c|}
\hline Ano & Evento & País & Org. & Principais conclusões \\
\hline 1973 & $\begin{array}{l}4^{\text {a }} \text { Conferência de Cúpula dos Países Não- } \\
\text { Alinhados }\end{array}$ & Argélia & MNA & $\begin{array}{l}\text { Recomendações de cooperação na reforma } \\
\text { de canais de comunicação existentes }\end{array}$ \\
\hline 1974 & $18^{a}$ Conferência Geral da Unesco & França & UNESCO & $\begin{array}{l}\text { Tratou direito de comunicar e lançou ideia } \\
\text { de fluxo livre e equilibrado de informação. }\end{array}$ \\
\hline 1975 & $\begin{array}{l}\text { Conferência dos Min. das Relações } \\
\text { Exteriores dos Países Não-Alinhados }\end{array}$ & Peru & MNA & $\begin{array}{l}\text { Compromisso de defender a NOMIC nos } \\
\text { fóruns internacionais. }\end{array}$ \\
\hline 1975 & $\begin{array}{l}\text { Seminário Dag Hammarskjöld de Jornalistas } \\
\text { do Terceiro Mundo }\end{array}$ & EUA & ONU & $\begin{array}{l}\text { Demanda por capacitação e cooperação } \\
\text { intergovernamental. }\end{array}$ \\
\hline 1976 & $\begin{array}{l}\text { Simpósio dos Países Não-Alinhados sobre } \\
\text { Informação }\end{array}$ & Tunísia & MNA & Formação de consenso sobre NOMIC. \\
\hline 1976 & 19a Conferência Geral da Unesco & Quênia & UNESCO & Constituição da Comissão MacBride. \\
\hline 1976 & 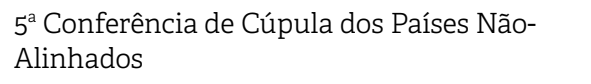 & Sri Lanka & MNA & $\begin{array}{l}\text { Criação conselho coord. para comunicação } \\
\text { e apoio a rede de agências do Sul. }\end{array}$ \\
\hline 1978 & $20^{a}$ Conferência Geral da Unesco & França & UNESCO & Comissão MacBride: Relatório preliminar. \\
\hline 1980 & $\begin{array}{l}4^{a} \text { Reunião Intergovernamental de Coord. da } \\
\text { Informação dos Não-Alinhados }\end{array}$ & Iraque & MNA & $\begin{array}{l}\text { Redação dos princípios da NOMIC para } \\
\text { coordenar ação internacional. }\end{array}$ \\
\hline 1980 & 21a Conferência Geral da Unesco & Iugoslávia & UNESCO & Aprovação do Relatório MacBride. \\
\hline
\end{tabular}

Adaptado de Aguiar (2018, p. 122).

Como é possível observar no Quadro 1, a UNESCO teve grande importância nessa agenda. No âmbito da instituição, esse debate teve como

16 Aguiar (2018, p. 109-126) analisa com profundidade esse processo. Segundo o autor, "em setembro de 1973, na IV Conferência de Cúpula do MNA [Movimento dos Não-Alinhados], em Argel, capital da Argélia recém-liberta, 75 países-membros discutiram a necessidade de uma Nova Ordem Econômica Internacional (NOEI), seguindo os trabalhos sobre as desigualdades estruturais entre países industrializados e países periféricos. Como parte desse projeto, os especialistas presentes enfatizaram a importância do setor da comunicação (entendida pela junção de comunicação social com telecomunicações) para a economia, inclusive nos países periféricos. [...] A cúpula teve ao final uma declaração econômica, uma declaração política [...] e um Programa de Ação para a Cooperação Econômica. [...] Nesse momento, com a analogia feita sobre a NOEI, teve início uma campanha paralela - que acabou tornando-se mais difundida e efetiva que a econômica - dos governos, jornalistas, entidades de mídia e agências de notícias dos países periféricos por uma reforma mundial na maneira como o sistema-mundo da comunicação (comunicação-mundo) estava organizado: chamou-se Nova Ordem Mundial da Informação e da Comunicação e passou à História pela sigla NOMIC" (AGUIAR, 2018, p. 117-118).

60 | Comunicação e usos do território: da violência da informação a uma outra globalização 
espaço principal a Comissão MacBride, cujo resultado - o chamado Relatório MacBride (UNESCO, 1980) - foi aprovado e publicado em sua 21 ${ }^{\text {a }}$ Conferência, em 1980. O relatório buscou apresentar o poder desequilibrado das agências de notícias dos países centrais e sugerir ações para quebrar os monopólios da informação (UNESCO, 1980, p. 253-272). Entre essas ações, estavam previstas políticas públicas de regulação da comunicação, ainda que em sugestões generalistas (MATTELART, 2001).

Esse debate na UNESCO na década de 1970 mobilizou a indústria de comunicação estadunidense, que o considerava um "perigoso precedente para a sobrevivência da liberdade de imprensa" e, sobretudo, uma ameaça ao princípio do livre fluxo de informações (MATTELART, 2001, p. 213), em uma concepção liberal de liberdade de imprensa. O descontentamento com o avanço da pauta da NOMIC e com o resultado do Relatório MacBride levou os Estados Unidos de Ronald Reagan e o Reino Unido de Margaret Thatcher a se retirarem da UNESCO, em 1985. O discurso norte-americano era de contrapor sua defesa de um livre fluxo de informações como oposição a um suposto controle governamental sobre a mídia - mas Roach (1987) demonstra como essa narrativa era contraditória e, na realidade, montada para a defesa dos interesses econômicos das grandes corporações midiáticas. A oposição narrativa dos defensores da NOMIC era defender um fluxo livre e equilibrado de informações (PALMER, 2012, p. 47-49)

Cabe, assim, compreender os fundamentos ${ }^{17}$ da narrativa difundida sobre o livre fluxo de informações, pois ela ainda representa o discurso dos meios hegemônicos em contraposição à agenda de democratização da mídia. Essa narrativa, de matriz liberal, parte de um entendimento da "liberdade" como um direito pré-político e inscrito exclusivamente na esfera privada (AMORIM, 2009). Esta "liberdade" seria concebida como liberdade negativa - isto é, o que

${ }_{17} \quad$ Não é a pretensão deste trabalho aprofundar nas matrizes filosóficas dessas concepções de liberdade de expressão e de imprensa. Para esse fim, recomenda-se os trabalhos de Barendt (2005), Amorim (2009), Lima (2010a) e Loreti e Lozano (2014). 
garantiria a liberdade seria a ausência de interferência na ação individual (ou na ação da empresa). No mesmo sentido, o Estado torna-se adversário da "liberdade" e qualquer forma de regulação - interferência - no setor é tratada como uma forma de censura (LIMA, 2010a). Para Charras e outros autores (2012), essa concepção empresarial de imprensa tem como características principais: (1) a redução da liberdade de imprensa à "liberdade de empresa" ${ }^{18 ;}$ (2) o empresário como o único titular do poder de informar e como quem mantém a relação com o poder político-administrativo; (3) a empresa informativa aceita a lógica do lucro, assimilando-se ao restante das atividades comerciais; e (4) a informação se transforma em mercadoria, e o público em consumidor.

Retomando a epígrafe de Alex Castro, essa "liberdade" não serve à expressão da maioria da população, mas apenas à atuação sem interferências das corporações midiáticas. Por isso, em contraposição, os movimentos que lutam contra a monopolização da comunicação constroem sua narrativa a partir da necessidade de garantir liberdade de expressão para todos. Nessa concepção de liberdade, de matriz republicana (AMORIM, 2009; LIMA, 2010a) e embasada na perspectiva dos direitos humanos, surgem exigências concretas para a adoção de regras jurídicas e políticas públicas com o objetivo de fomentar a pluralidade e diversidade de vozes (LORETI; LOZANO, 2014, p. 47). Conforme Loreti e Lozano (2014, p. 53), a insuficiência da perspectiva "negativa" de liberdade fica clara quando a expressão de opiniões se dá em contextos de escassez, quando a proteção à autonomia de quem toma a voz pública se torna insuficiente perante a prevalência de certos discursos sobre outros agentes silenciados. A ameaça à liberdade de expressão, então, já não é só a censura rígida, mas também a exclusão. Por isso a defesa é de um reconhecimento ao direito à comunicação para todos, que só pode se expressar a partir da criação de condições para que todos tenham voz e para que não haja o monopólio da palavra.

\footnotetext{
18 Muitas vezes, os meios hegemônicos colocam em circulação uma confusão entre liberdade de expressão e liberdade de imprensa/empresa (LIMA, 2010), de modo a defender seus interesses corporativos passando a impressão da defesa da liberdade de fala.
} 
Conforme Rodriguez (2012), a chamada Nova Ordem Mundial da Informação e da Comunicação, pautada na UNESCO, deveria ser vista como um processo, ao invés de um produto em si. Para o autor, se o tema esteve interditado nos anos 1980, ele voltou a ser um processo em movimento graças à retomada da agenda pelos movimentos sociais latino-americanos nos anos 1990 e 2000, no bojo da resistência contra o dogma neoliberal e a hegemonia do mercado (RODRIGUEZ, 2012, p. 78).

Após 1983, com o fim da ditadura, quatro processos principais modelaram a organização da comunicação no território argentino: o fim da censura direta e prévia; a convergência tecnológica (audiovisual, informática e telecomunicações); a concentração de propriedade das empresas em poucos e grandes grupos; e a centralização geográfica da produção de conteúdos (BECERRA, 2010). Esses dois últimos, por contrariarem a comunicação democrática e o direito à comunicação, tornaram-se alvos das mobilizações e disputas por uma outra comunicação, que estavam sendo construídas desde então por um amplo conjunto de organizações da sociedade civil e de movimentos sociais. Todavia, a barreira do alcance dessa contranarrativa - ou, poderíamos dizer, de uma outra psicosfera - sempre foi um desafio grande, já que a mídia monopolizada interdita esse debate e limita a circulação desses discursos.

As lutas sociais contrárias à monopolização da comunicação não estão isoladas, mas compõem um conjunto de lutas democráticas fortalecidas a partir do enfrentamento às ditaduras e, após a década de 1990, da resistência contra o neoliberalismo no continente. Não se trata, portanto, de um processo exclusivo do território argentino - é importante compreender, na presente análise, a América Latina como uma totalidade. Essas lutas ocorreram em diversos países e, em muitos casos, os movimentos sociais, organizações, entidades e partidos envolvidos articularam essas lutas em redes. No caso das disputas por novas legislações de comunicação, Waisbord e Segura (2016) apontam a atuação de 
agentes e redes latino-americanas como a Agência Latino-americana de Informação (ALAI), a Associação Latino-americana de Educação e Comunicação Popular (ALER) e a Alianza Regional por la Libertad de Expresión y el Derecho a la Información, além de outras redes globais de movimentos e organizações, com participação de diversos entidades latino-americanas: a Associação Mundial de Rádios Comunitárias (Amarc) e a Associação para o Progresso das Comunicações (APC). Merece destaque, também, o Fórum Social Mundial (FSM) e, mais recentemente (em 2016), a Alianza por la Diversidad y el Pluralismo en la Comunicación.

As últimas décadas marcaram disputas de projetos de comunicação no território argentino. Em relação à possibilidade de regulação democrática da comunicação, há agentes e narrativas em disputa: as grandes empresas clamando por sua liberdade irrestrita de atuação e de concentração - apoiadas por outros agentes do discurso neoliberal - em contraposição aos diversos movimentos sociais e entidades da sociedade defendendo a necessidade de uma regulação democrática da comunicação, ampliando a diversidade e a pluralidade das vozes em circulação. Esses sentidos são difundidos no território com suporte de um conjunto de materialidades - uma parte da tecnosfera usufruída com finalidades diversas, como as rádios comunitárias, a imprensa independente e alternativa e ações de movimentos socioterritoriais e outras organizações da sociedade civil.

Após o desaparecimento das ditaduras na América Latina e o período neoliberal e privatizante que dominou a década de 1990, o continente entrou no século XXI protagonizando uma "virada" à esquerda (SERRANO, 2011, p. 85), por meio das vitórias eleitorais de Hugo Chávez (Venezuela, em 1998, 2000, 2006 e 2013), Luís Inácio Lula da Silva (Brasil, em 2002, 2006), Evo Morales (Bolívia, em 2005 e 2009), Rafael Correa (Equador, em 2007 e 2013), Daniel Ortega (Nicarágua, em 2006 e 2011) - e, na Argentina, Néstor Kirchner e Cristina Fernández de Kirchner (em 2003 e 2007, respectivamente). Essa "guinada" a governos de 
esquerda ou centro-esquerda é resultado do processo político mais amplo de resistência antineoliberal e acompanha um novo conjunto de possibilidades para os territórios latino-americanos - podendo ser compreendida como um evento geográfico (SANTOS, 2006) na América Latina.

Partícipes desse processo amplo de lutas sociais, os esforços por um novo marco regulatório para as comunicações na Argentina foram construídos desde a década de 1980 por um grande conjunto de movimentos sociais e entidades da sociedade civil. Após a redemocratização, várias entidades sindicais, sociais e universitárias do campo da comunicação começaram a se articular politicamente em torno da demanda de democratização a comunicação, buscando modificar o marco normativo da comunicação, o Decreto-Lei n. 22.285/1980 (SEGURA, 2011). Durante os anos 1980, várias instituições, associações e movimentos foram se consolidando nessa agenda. Conforme Segura (2011, p. 85, tradução nossa), essa movimentação continuou na década de 1990, diante da acelerada concentração de propriedade dos meios, e se aprofundou a partir da crise de 2001-2002, "quando outras organizações sociais, cujo objeto principal de intervenção não era a comunicação, começaram a considerá-la chave para alcançar sua própria apresentação, visibilidade e legitimidade no espaço público, articular-se e pensar outro modelo de país e de democracia".

Após esse período de fortalecimento das organizações e da demanda, os principais avanços ocorreram durante a década de 2000, quando culminou na formação de uma ampla coalizão de agentes que fortaleceu a pauta e incidiu na produção de uma outra psicosfera - que poderia ser denominada como uma psicosfera de suporte a essas transformações, no sentido da viabilização das condições para a formulação de uma nova política de comunicação argentina. A Coalizão por uma Radiodifusão Democrática (CRD), lançada oficialmente em 2004, reuniu: centrais sindicais e federações de sindicatos de imprensa; organizações de direitos humanos; universidades; associações profissionais, 
movimentos socioterritoriais; associações de rádios comunitárias, universitárias, cooperativas, de fronteira e indígenas; intelectuais nacionais e estrangeiros vinculados à comunicação; e funcionários do setor que atuavam no Executivo e no Congresso (SEGURA, 2011, p. 97). Segundo Segura (2011, p. 84), a coalizão foi a aliança mais ampla conformada em torno da agenda da democratização das comunicações.

As propostas consolidadas da CRD foram apresentadas em 2004, como "21 Pontos para uma Nova Lei de Radiodifusão para a Democracia". O lançamento se deu quando o país completava 21 anos da recuperação democrática, no dia 21 de agosto (Dia Nacional da Radiodifusão), em um programa transmitido pela Rádio Nacional para todo o país e pela Agência Pulsar para toda a América Latina (CÓRDOBA, 2011). A partir de então, o movimento implantou uma ampla agenda de atividades, em duas frentes: (1) incidir diretamente sobre funcionários do Poder Executivo e legisladores do Congresso, participando do projeto de lei em redação; e (2) incidir na opinião pública, buscando gerar um consenso sobre a necessidade de modificar a lei de radiodifusão e de fazê-lo na direção dos 21 pontos (SEGURA, 2011, p. 101).

Além de manifestações públicas, foram elaboradas diversas peças para difundir os sentidos que se defendia com a nova regulação da comunicação, produzindo, desde o início, uma arena de disputas simbólicas - e, posteriormente, legais - com os meios hegemônicos, sobretudo o Grupo Clarín (5). 


\section{Figura 5: Trecho de vídeo da Coalizão por uma Radiodifusão Democrática de Santa Fé}

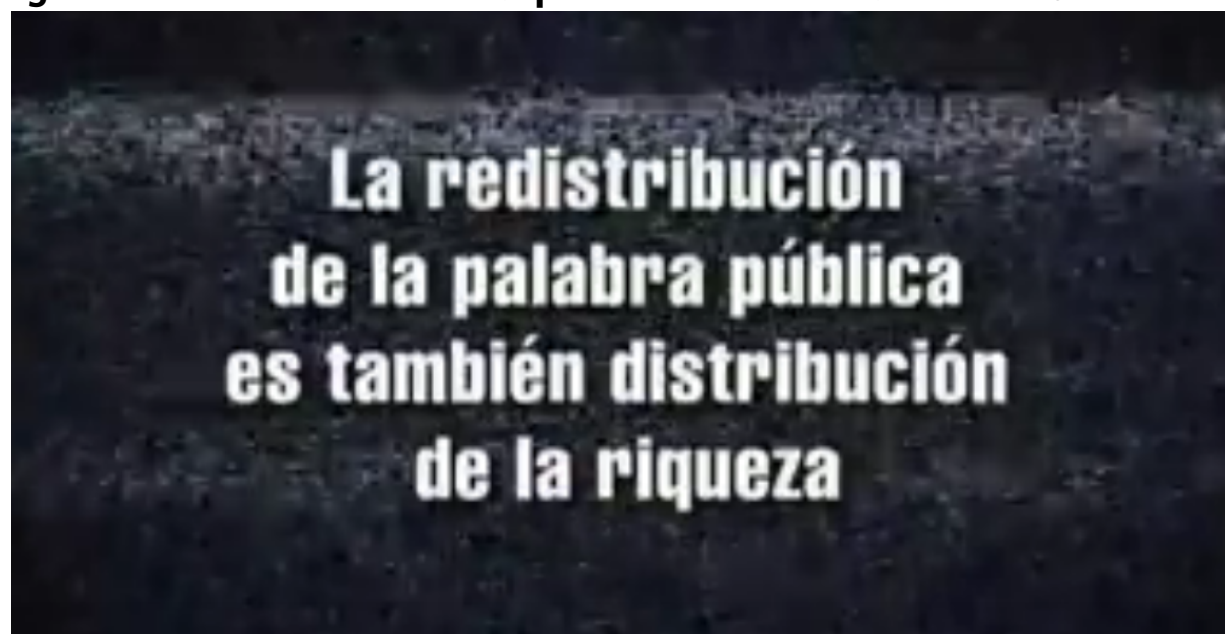

Em tradução livre: "A redistribuição da palavra pública é também uma distribuição da riqueza”. Fonte: trabalho de campo em Buenos Aires (2016).

É fundamental reforçar a importância desse campo de disputas de sentidos para a organização do território e para as disputas de projetos de transformações espaciais. Se, como visto, a difusão do meio geográfico adaptado ao funcionamento atual do capitalismo acompanhou a produção de uma psicosfera (RIBEIRO, 1991), os projetos contra-hegemônicos também precisam disputar a produção e circulação de outros sentidos para a organização do espaço. Ainda que na Argentina o foco do debate dos movimentos sociais pelo direito à comunicação estivesse na aprovação de um novo marco normativo, os agentes envolvidos nesse projeto de democratização dos meios tinham o desafio da ampliação de escala e lutavam para a produção de uma correlação de forças que possibilitasse um novo conjunto de ações para reorganizar as comunicações.

A conjuntura se tornou mais oportuna alguns anos depois do lançamento dos 21 pontos, quando os princípios defendidos pela Coalizão foram assumidos pelo governo de Cristina Fernández de Kirchner (2007-2015), a partir do acirramento de um conflito entre o governo nacional com os principais conglomerados de comunicação do país, em especial o Grupo Clarín. O aparecimento desse conflito se deu com a chamada "crise do campo" ${ }^{19}$, em março

19 O estopim da crise foi uma medida econômica (Resolução 125, de retenções móveis) de regulação e taxação de exportações, que estabelecia uma fórmula mediante a qual alguns produtos agrícolas - incluindo a soja - 
de 2008. Na ocasião dessa crise, grandes grupos de mídia, como o Clarín, passaram a fazer uma oposição sistemática ao governo, apoiando os discursos ruralistas. As tensões em torno das abordagens midiáticas se acirraram - Piccone (2015, p. 14) chegou a considerar que o monopólio midiático teria exibido, nesses tempos, sua manipulação mais explícita da opinião pública no país.

No mês seguinte ao início da crise, o governo recebeu a Coalizão por uma Radiodifusão Democrática e iniciou um conjunto de reuniões para a mudança da lei de radiodifusão (PICCONE, 2015, p. 15). Assim, a partir do conflito do campo foram criadas as condições para que o governo assumisse a agenda da Coalizão e elaborasse, em diálogo com os movimentos, um projeto de lei baseado nos 21 pontos defendidos por eles.

Uma estratégia central para difundir esse debate e fazer circular a crítica aos monopólios midiáticos foi ligada à transmissão de futebol pela televisão. As corporações midiáticas detinham a exclusividade da transmissão das partidas de futebol. Como os direitos de transmissão são um dos principais meios de financiamento dos grandes clubes, essas empresas passavam a ter grande poder sobre a organização do esporte e restringiam a exibição das partidas para expandir seu lucro ${ }^{20}$. Em meio ao debate sobre uma nova regulação democrática da comunicação, surgiu uma iniciativa do governo de Cristina Fernández chamada Fútbol para Todos. Segundo o idealizador dessa iniciativa, Gabriel Mariotto ${ }^{21}$, o monopólio midiático com controle das transmissões de futebol gerava situações como agrupamentos de pessoas em frente a televisores de estabelecimentos comerciais e jogos que, mesmo na televisão a cabo, ao terem

pagariam mais imposto caso seu preço aumentasse no mercado internacional (PICCONE, 2015). Por se tratar de uma disputa com setores dominantes, o conflito ganhou escala e visibilidade, diferente de outros conflitos no campo que são constantemente invisibilizados - sobretudo aqueles que envolvem agentes hegemonizados (MANZANAL; ARZENO, 2010, p. 198).

20 A respeito da dinâmica mercantil do futebol e o papel dos países latino-americanos no mercado global, conferir Samaniego (2014).

21 Entrevista realizada pelo autor com Gabriel Mariotto, no Centro Cultural Padre Mujica (Banfield) em fevereiro de 2016. Mariotto é jornalista, professor universitário e político. Foi indicado pelo governo de Cristina Fernández de Kirchner para atuar para a aprovação da nova lei da comunicação audiovisual. Dirigiu o Comfer e a AFSCA. Posteriormente, foi vice-governador da província de Buenos Aires (2011-2015). 
início, tinham as câmeras voltadas à arquibancada, para incentivar a compra da partida na modalidade pay per view (MARIOTTO, 2016). Como narra Sel (2013, p. 147), só era mostrada a arquibancada, e não as jogadas - portanto, a televisão funcionava como um rádio, onde o narrador transmitia o que passava mas onde não era possível ver, exceto uma imagem fixa fora do jogo (6).

\section{Figura 6: Imagens de transmissão de partidas de futebol antes do Fútbol Para Todos}
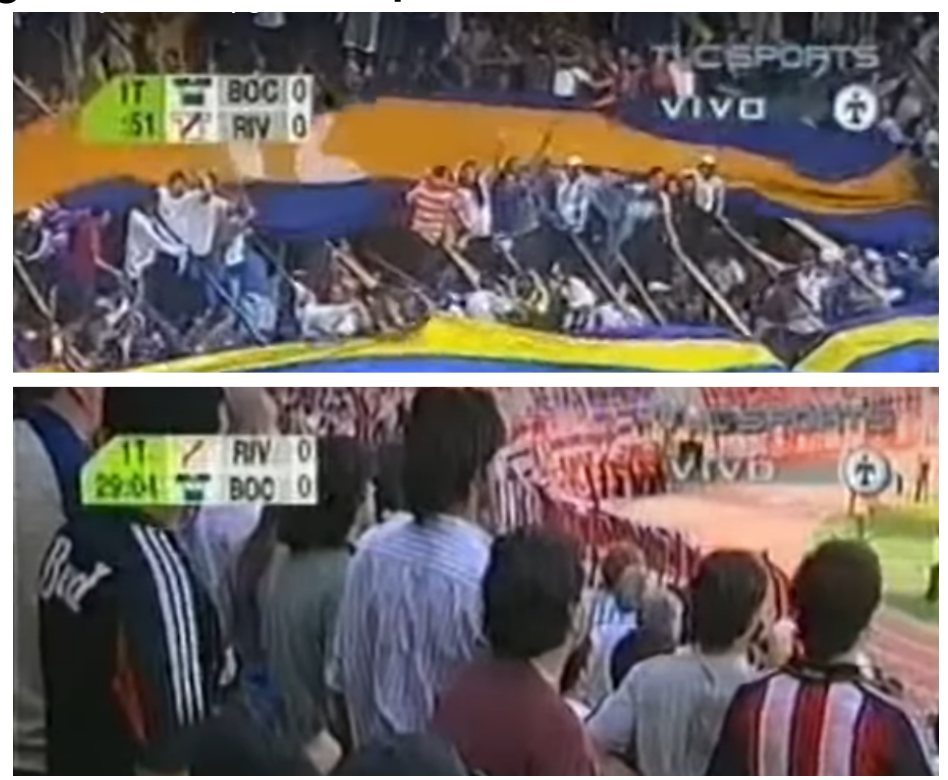

A narração (áudio) acompanhava imagens apenas da arquibancada, durante toda a partida.

Fonte: vídeos obtidos em trabalho de campo.

O governo federal utilizou essa situação da transmissão futebolística como forma de sensibilizar a população sobre os danos da concentração midiática e as possibilidades de democratização da comunicação. O programa Fútbol para Todos se origina com a Decisão Administrativa federal 221 de 21 de agosto de 2009, e tinha entre os objetivos implantar um modelo que permitisse que o futebol televisionado chegasse à população gratuitamente pela televisão aberta (ARGENTINA, 2009a).

A partir de um acordo do governo federal com a Associação do Futebol Argentino (AFA), rompeu-se o contrato ${ }^{22}$ desta com a empresa TyC/Clarín (que

22 Alabarces e Duek (2010, tradução nossa) alertam que "a AFA tem mostrado que pode encerrar um contrato do dia para a noite, aliando-se com agentes inimagináveis. Isso pode acontecer novamente. Porque, no final das contas, público ou privado, codificado ou aberto e 'para todos' ou 'para poucos', o futebol nunca deixa de ser um grande negócio". No cap. 5, são analisadas transformações no tema após a mudança de governo, em 2015. 
detinha os direitos de transmissão desde 1985) e houve uma estatização das transmissões televisivas de futebol. Segundo Servetti (2013), o programa pretendeu democratizar o acesso à transmissão televisiva dos torneios de futebol da primeira divisão, outorgando, para isso, a esse esporte o caráter de "interesse público". Um avanço significativo foi acabar com o "fosso" entre os que podiam assistir ao futebol pela televisão porque pagavam um serviço extra e aqueles que não podiam assinar um serviço de televisão a cabo e, menos ainda, pagar uma taxa especial para ver as partidas (SERVETTI, 2013).

O programa não implicou só a possibilidade de assistir gratuitamente aos jogos de futebol. Ele contribuiu, também, para promover a programação da Televisão Pública (Canal 7) e elevar sua audiência global (NATANSON, 2010, p. 64), já que os jogos eram transmitidos no canal público e atraíam novos espectadores. Segundo Sel (2013, p. 147-148), o Fútbol para Todos permitiu, ainda, mudar a relação entre as operadoras de TV a cabo e as pequenas e médias empresas e cooperativas do setor, que puderam transmitir jogos e diversificar seus serviços.

Provavelmente, um dos principais avanços do Fútbol para Todos tenha sido sua participação na produção da psicosfera de suporte para a transformação da comunicação na Argentina e para a sensibilização da situação de monopolização da informação ${ }^{23}$. Como afirma Marino (2017b, p. 74), seu impacto fundamental estava ligado a dar espaço na mídia massivamente ao debate em torno do projeto da Lei de Serviços de Comunicação Audiovisual (LSCA) em 2009. O programa foi usado em diversas ações em defesa de uma nova lei para o audiovisual (7).

23 Essa sensibilização também foi o objetivo de um programa chamado 6-7-8, veiculado na Televisão Pública de 2009 a 2015. O foco do programa era a crítica de mídia, e predominavam "temas situados na interseção entre o campo político e o midiático, tratados de modo a provocar reflexões que, inevitavelmente, levam ao questionamento e a desacreditar políticos de oposição e a chamada mídia hegemônica" (SOMMA NETO; DIAS, 2016, p. 17). Para além do marco da LSCA, entende-se aqui o 6-7-8 dentro das estratégias de comunicação política do kirchnerismo (PALMA, 2014, p. 218), que não compõem o objeto específico desta tese. 


\section{Figura 7: Cartaz chamando a um ato em defesa da aprovação da Lei de Serviços de Comunicação Audiovisual, no Dia da Radiodifusão Argentina de 2009}

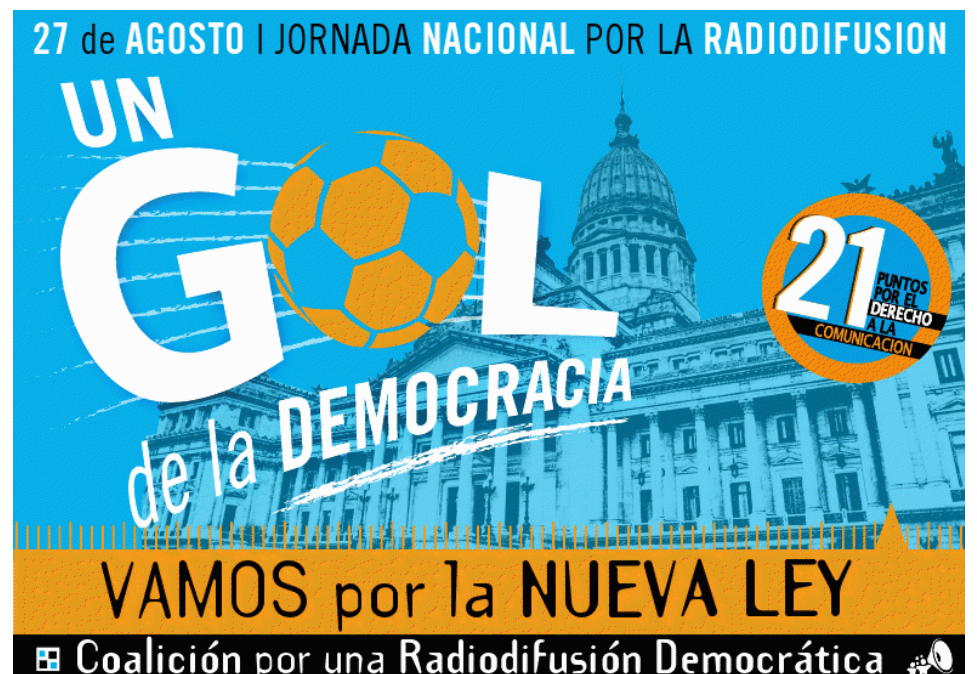

Fonte: Coalición por una Radiodifusión Democrática.

Mariotto (2016) afirma que o Fútbol para Todos conseguiu levar o debate da academia e das organizações sociais, que demandavam uma nova lei de comunicação, para o cotidiano da maioria da população. Mesmo alguns críticos do kirchnerismo, como Vásquez e Cayón (2014) ${ }^{24}$, afirmam que pouquíssimos negam como é positivo que o esporte preferido dos argentinos chegue ao vivo, diretamente e de forma gratuita a todos os televisores do país.

Segundo Lara (2013, p. 141), o programa deu ao governo mais legitimidade social, pois afetou um negócio importante do grupo econômico Clarín e ainda garantiu o acesso dos cidadãos a um conteúdo relevante para a tradição cultural argentina. Conforme relato do pesquisador Damián Loreti (apud LARA, 2013), Mariotto - que já atuava em defesa de uma nova lei de comunicação que acabasse com os monopólios - assumiu o Comitê Federal de Radiodifusão em julho de 2008, mas já antes de assumir, teria dito a Loreti: “vamos fazer a lei". O programa Fútbol para Todos foi um elemento central na circulação dessas narrativas e na produção de uma psicosfera de suporte para a

24 A obra (VÁSQUEZ; CAYÓN, 2014) faz diversas críticas ao Fútbol Para Todos. Entre elas, destaca-se o que os autores consideram ser um "uso político" do programa, além das propagandas (elaboradas pelo governo) veiculadas ao longo da programação e da quantidade de recursos públicos investidos. 
aprovação da nova Lei de Serviços de Comunicação Audiovisual.

Para a confecção da lei, foram realizados diversos fóruns, com participação de cerca de dez mil pessoas, que realizaram 1200 contribuições à proposta de lei apresentada (BUSSO, 2011, p. 31). A partir dos debates públicos e do Fútbol para Todos, ganharam força campanhas do governo e da sociedade em crítica à monopolização da comunicação e em defesa da regulação democrática dos meios, ao mesmo tempo em que os principais grupos de mídia do país faziam ampla campanha contrária. Como afirma Jensen (apud BLAUSTEIN; DAICICH, 2011), havia a intenção de que os meios tivessem que tocar nesse debate. Para ele, a primeira vitória "cultural" da Coalizão pela Radiodifusão Democrática foi colocar na agenda dos meios o debate sobre a lei de serviços de comunicação audiovisual - ainda que essas empresas seguissem a chamando de "lei da mordaça" ou "ley de medios K" (em referência ao kirchnerismo ${ }^{25}$.

Duas das peças que o Grupo Clarín produziu para a disputa contra a nova política de comunicação (8 e 9) representavam aspectos centrais de sua narrativa: a primeira questionava "meios ou medos?", em uma narrativa de que a lei era contra o grupo, para censurá-lo de críticas que fazia ao governo; a segunda afirmava que o mercado de comunicação argentino seria um dos mais competitivos do mundo e entrava na disputa de entendimento do que configura um monopólio.

25 No Brasil, a abordagem do debate sobre a aprovação e a vigência da LSCA argentina foi, também, predominantemente contrária à nova lei, reproduzindo o discurso do Clarín. Ao analisar editoriais de O Globo e O Estado de S. Paulo, Waltz (2013, p. 14) percebeu "um discurso afinado, em que a formação de grandes impérios de mídia é apresentada como uma forma de garantir a liberdade de imprensa [...]. Ambos explicitam sua oposição a qualquer proposta de intervenção estatal de reforma da regulação ou do sistema midiático". Para ilustrar a abordagem, cf. matéria de capa da revista Época (do Grupo Globo) de 24/11/2012 (disponível em http://bit.ly/epocaleidemeios): "Ela quer calar a Argentina - a truculenta campanha da presidente Cristina Kirchner contra a imprensa independente pode acabar se voltando contra ela própria”. O primeiro parágrafo da matéria traz: "O país ferve na panela da insatisfação, mas ela aguarda ansiosa a chegada do dia 7 de dezembro, apelidado 7D. Nesse dia, passará a vigorar uma lei talhada para intimidar e reduzir a influência de grupos de mídia que criticam o governo e denunciam suas irregularidades, conhecida como Lei de Meios". 


\section{Figura 8: 'Medios o Miedos?': trechos de vídeo do Grupo Clarín na TV, contra a LSCA}

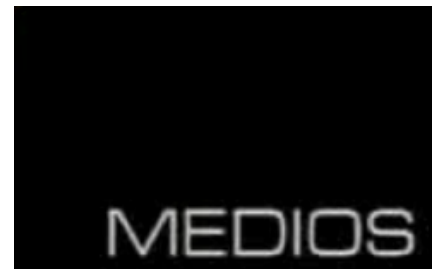

Publicidad Institucional Grupo Clarin

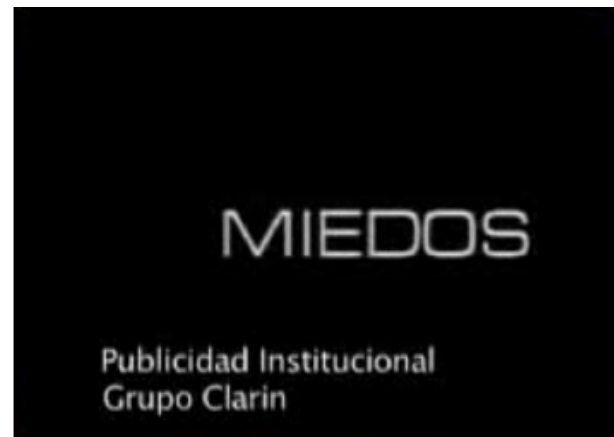

Grupo Clarin

"Se um governo ocupa os meios para seu lado, se convertem em outra coisa. Se uma lei é contra alguém, no fim das contas é contra todos". Trad. própria. Fonte: documentário "La Cocina” (BLAUSTEIN; DAICICH, 2011).

Figura 9: ‘Clarín en el mercado argentino’: trechos de vídeo do Grupo Clarín, rebatendo críticas da concentração da mídia

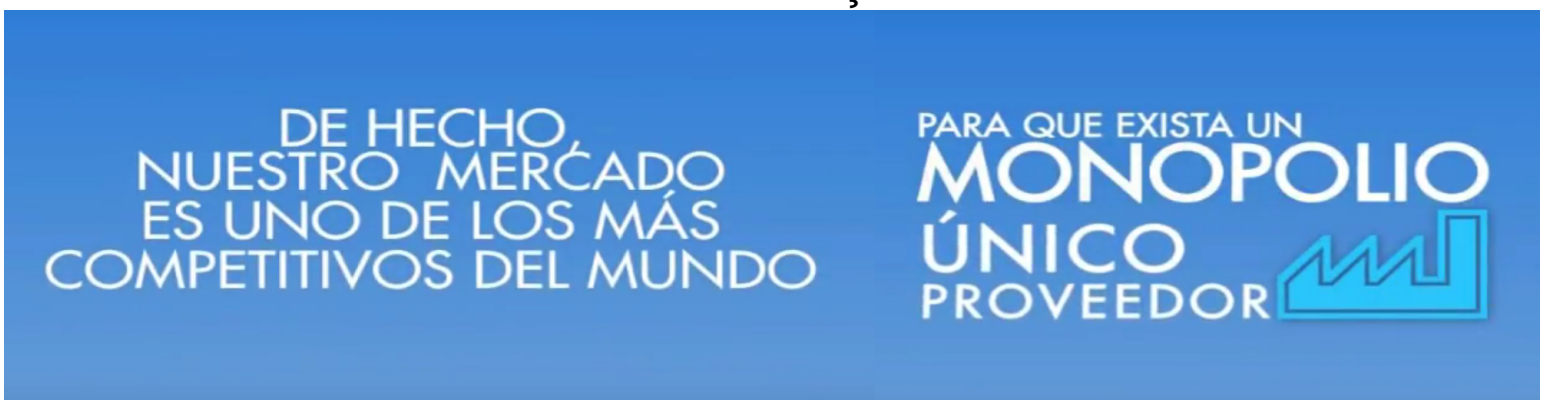

Alguns trechos da propaganda: “Os meios do Grupo Clarín são escolhidos todos os dias dentro de uma oferta muito ampla. Na verdade, nosso mercado é um dos mais competitivos do mundo. Para que exista um monopólio, deve haver um único provedor de produtos ou serviços. As pessoas não teriam possibilidade de

escolher. Obviamente, nem o Grupo Clarín nem algum de seus concorrentes são um monopólio. [...] A

Argentina é um dos países com maior diversidade e concorrência midiática em todo o mundo." Fonte: Clarín (2011).

A militância a favor e contra a derrocada do decreto-lei de radiodifusão da ditadura e pela democratização da comunicação ocupou ruas, fóruns, rádios e praças (PICCONE, 2015). A lei foi aprovada e sancionada em 2009, sob as intensas críticas dos conglomerados midiáticos.

Nos quatro anos seguintes, o tema seguiu em disputa, a partir de uma judicialização do caso - especialmente dos artigos que tratavam dos limites de concentração de propriedade e da adequação dos megagrupos existentes. $\mathrm{O}$ enfrentamento no Judiciário para afirmar sua constitucionalidade e o acompanhamento de sua aplicação nos seis anos seguintes também trouxeram o 
tema ao centro do debate público.

$\mathrm{Na}$ disputa simbólica, os conglomerados seguiam se afirmando como vítimas da nova lei, e atacando o governo nacional e outros governos da América Latina, que propuseram políticas antimonopolistas para a comunicação (10).

Figura 10: ‘Ley de medios: articulos denunciados por inconstitucionales’: vídeo veiculado pelo Grupo Clarín questionando judicialmente a LSCA
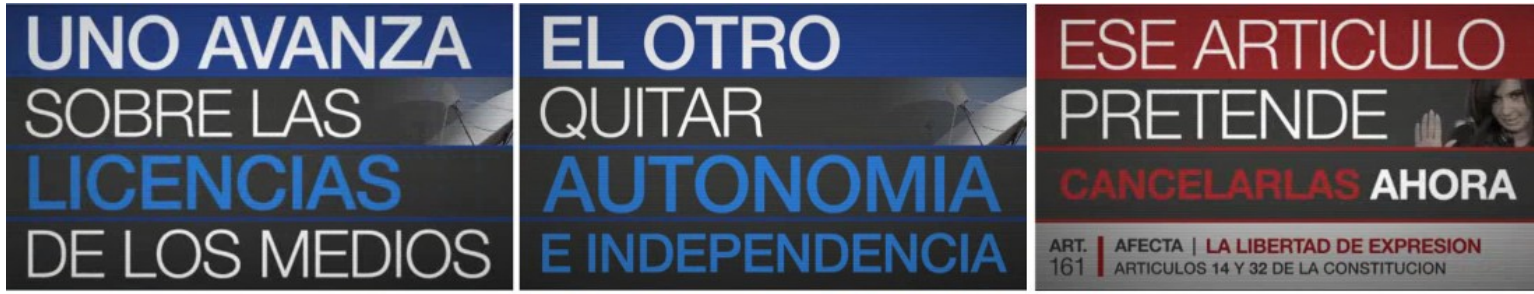

EN CUALQUIER

PARTE DEL MUNDO

SERIA INCONCEBIBLE

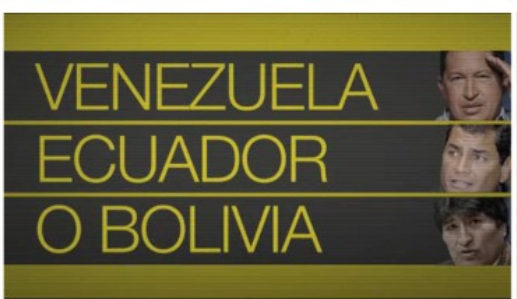

QUEDARSE CON LOS

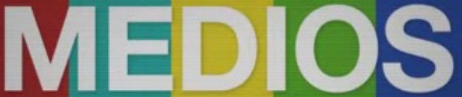

QUE EL GOBIERNO

NO PUEDE CONTROLAR

DEBILITAR A LOS MEDIOS HACERLOS VULNERABLES
EL OBJEIMO ES MUY CLARO

AHORA

ART. | AFECTA | LA LIBERTAD DE EXPRESION 161 ARTICULOS 14 Y 32 DE LA CONSTITUCION
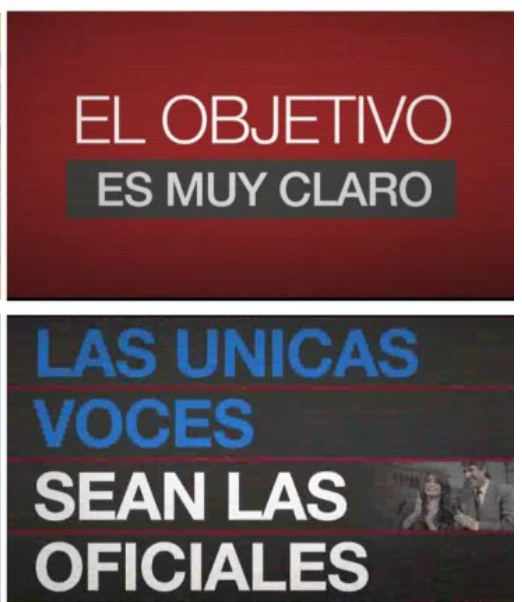

Tradução livre de trechos da propaganda: “Segundo a denúncia [do Clarín à Corte Suprema], dois artigos dessa Lei desconhecem vários direitos constitucionais [...] Os artigos 161 e 45 da Lei de Meios configuram essas vias indiretas [da violação da liberdade de expressão]: um avança sobre as licenças dos meios, outro busca acabar com a autonomia e independência. [...] O artigo 161 pretende cancelar as licenças agora. Isto, em

qualquer parte do mundo, seria inconcebível. Nem mesmo a Venezuela, o Equador e a Bolívia, cujos governos avançaram contra a imprensa, chegaram a ditar leis retroativas. [...] O objetivo é muito claro: ficar com os meios que o governo não pode controlar [... e] debilitar os meios, fazê-los vulneráveis e dependentes

dos subsídios estatais [...] para que as únicas vozes que existam sejam as oficias". Fonte: Clarín (2016).

Nesse processo de disputa e judicialização, um momento emblemático foi a campanha realizada em torno do dia 7 de dezembro de 2012 (11), chamado de 7D, como conta Martins (2013):

“Monopolios o nación”, aponta categoricamente o impresso afixado no muro; "Clarín miente", denuncia a pichação feita no alto de um dos muitos prédios novecentistas da capital argentina. As distintas formas de manifestação 
assinalavam a chegada do "7D", ou 7 de dezembro, dia estabelecido pela Suprema Corte do país, em maio de 2012, como prazo para que as empresas de comunicação apresentassem planos de adequação à nova legislação que regulamenta os serviços audiovisuais naquele país [...]. A própria campanha em torno do $7 \mathrm{D}$ foi lançada durante intervalos de partidas de futebol.

\section{Figura 11: ‘Aviso sobre la plena vigencia de la Ley de Medios (LSCA) a partir del 7 de diciembre': vídeo da autoridade de aplicação da LSCA para $07 \mathrm{D}$}
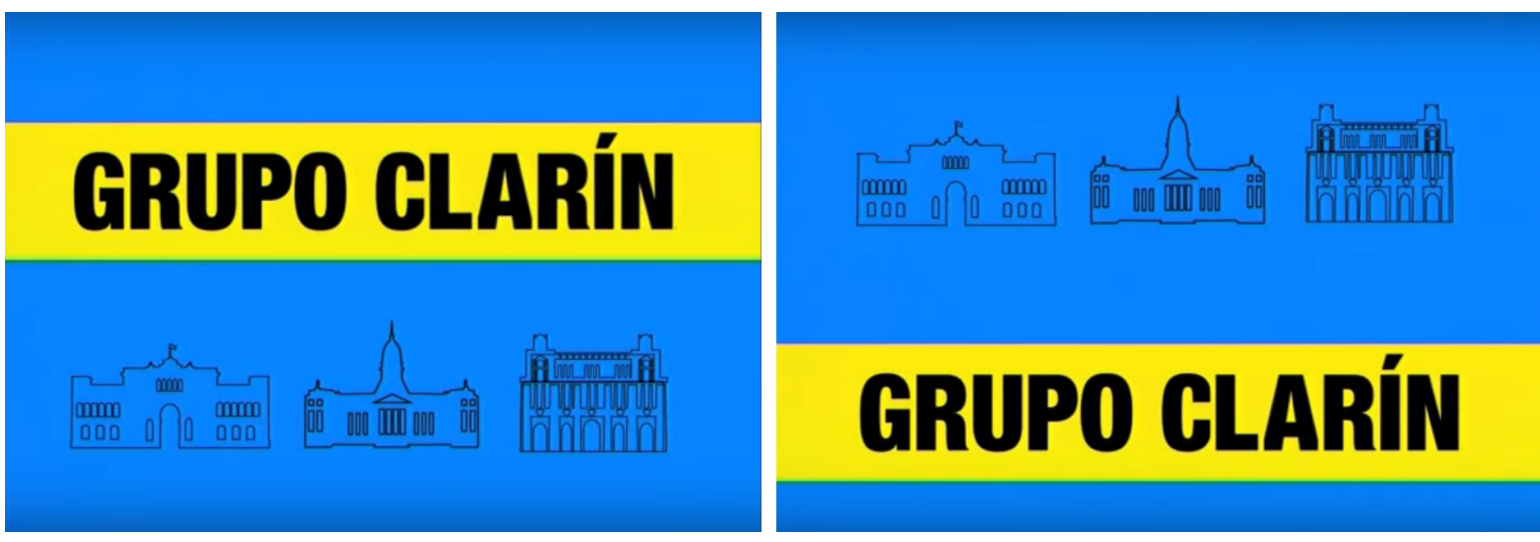

Alguns trechos da peça em questão (em destaque o trecho das imagens): "Três anos depois de aprovada a lei, o Grupo Clarín se nega a tudo: não reconhece o AFSCA como autoridade de controle e aplicação da lei; se nega a apresentar um plano de adequação [das licenças]; se nega a cumprir a lei. Dessa forma, o Grupo Clarín ignora os três poderes da democracia: o Executivo, ao não reconhecer o AFSCA; o Legislativo, ao não querer cumprir com uma lei aprovada pelo Congresso Nacional há três anos; o Judiciário, ao ignorar a decisão da Suprema Corte. Mas pode um grupo empresário estar acima das instituições democráticas de um país? Claro que não". Fonte: Casa Rosada (2012).

As inserções de propagandas políticas como essa - em favor da nova Lei de Serviços de Comunicação Audiovisual e contrárias ao monopólio marcaram o programa Fútbol Para Todos. Nas palavras de Vásquez e Cayón (2014), enquanto o Clarín lançava propagandas chamadas "Quem Mente" e seus empregados se manifestavam por outras fontes, o governo respondia através do futebol. Segundo estes autores, "um trabalho do setor privado assegura que foram emitidas seis horas e vinte e um minutos e trinta e nove segundos de publicidade referente ao 7 de Dezembro (7D)" (VÁSQUEZ; CAYÓN, 2014, n.p, tradução nossa).

Muitos movimentos sociais e instituições participaram do 7D, tanto nas ruas quanto na disputa simbólica sobre a vigência da lei (12). 
Figura 12: 'Ley de Medios, Una ley para que hablemos todos’: trechos de vídeo em defesa da Lei de Meios, elaborada no conurbano de Buenos Aires

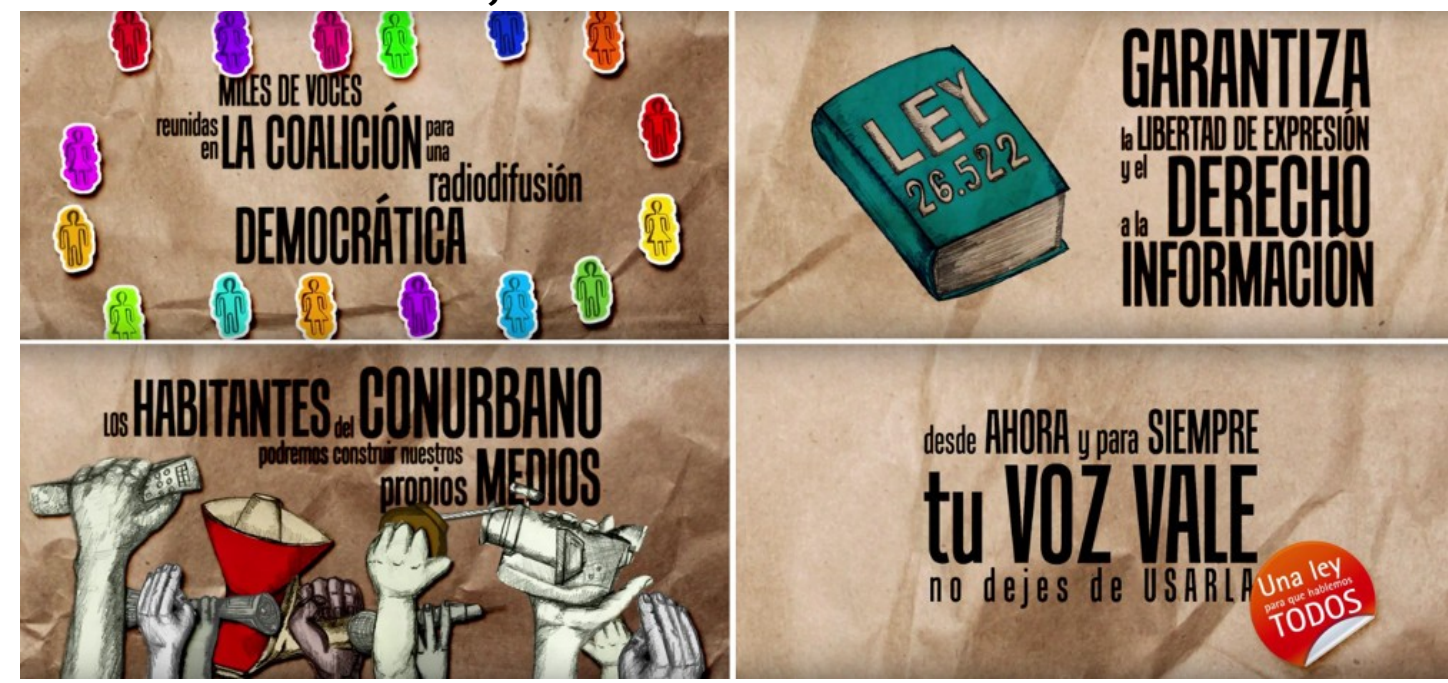

Em tradução livre, trechos do vídeo: "A lei de Serviços de Comunicação Audiovisual foi elaborada com a contribuição de milhares de vozes, reunidas na Coalizão por uma Radiodifusão Democrática. Mais de 300 organizações apresentaram as bases [...] Nós, habitantes do conurbano e de todo o país temos a possibilidade de construir nossos próprios meios, para que nossas vozes sejam escutadas. Desde agora e para sempre, sua voz vale. Não deixe de usá-la." Fonte: Trabalho de campo (Florencio Varela, 2016).

Também foram veiculadas diversas peças nos grandes meios de comunicação, criticando os aspectos da lei que eles judicializaram (13).

Figura 13: ‘Ley de medios: del slogan a la realidad’: vídeo do Grupo Clarín
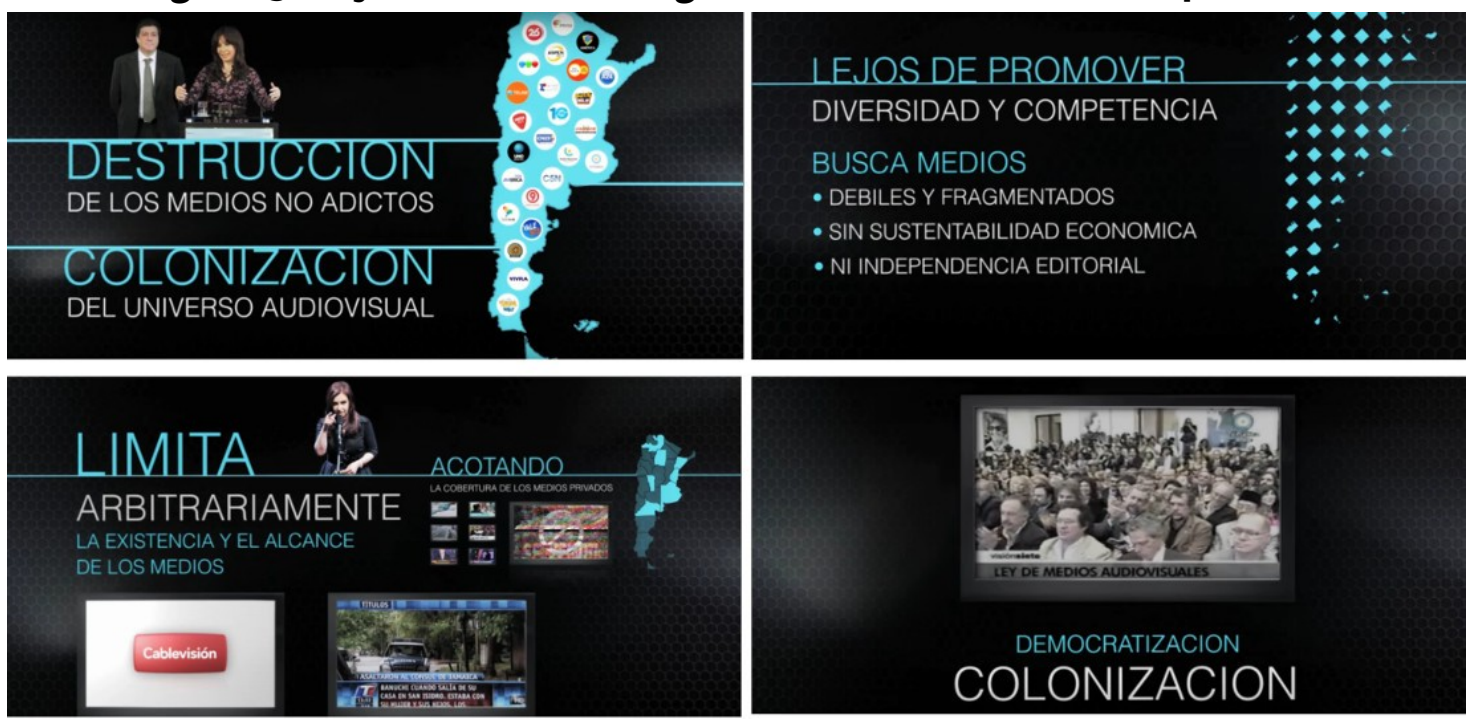

"A lei restringe a liberdade de expressão [...] quando limita arbitrariamente a existência e o alcance dos meios que são de livre criação [...] beneficiando grupos estrangeiros, que podem explorar quantos meios queiram. [...] afeta os princípios de igualdade e livre concorrência [...] afeta a segurança jurídica, quando pretende ignorar, em um caso único no mundo, licenças plenamente vigentes que foram outorgadas pelo mesmo Estado [...] Democratização ou colonização? Diversidade ou hegemonia oficial? Meios públicos ou meios militantes? Argentinidade ou estrangeirização? Meios locais ou corporações globais?". Fonte: Clarín (2012). 
A participação do governo nacional pautando o debate e propondo a aprovação de uma nova lei obrigou os grandes grupos de mídia a abordarem o assunto, ainda que em ataques sistemáticos à iniciativa. A estratégia do Grupo Clarín tratou de se identificar como "imprensa independente" sob ameaça do governo, defendendo que a regulação representaria uma censura ao grupo e, portanto, um ataque à "liberdade de expressão" (correspondendo à visão liberal já apresentada). Outra tática foi a partidarização da LSCA como uma lei "kirchnerista" que buscaria atacar seus adversários políticos. Como visto, as respostas não vieram apenas do governo nacional, mas de diversos movimentos potencializados pelo conjunto de ações então em andamento, de distintas regiões do país. A tensão conseguiu ampliar a escala da disputa em torno de uma outra política de comunicação e levar o questionamento aos monopólios da mídia a mais lugares.

A grande mobilização do 7D demonstra, também, a centralidade dos questionamentos aos monopólios e das ações para expandir o alcance do debate sobre a temática e produzir uma outra psicosfera para a concretização da defesa da Lei de Serviços de Comunicação Audiovisual e de um conjunto de ações na direção de uma democratização da comunicação. Conforme Postolski (2013, p. 113), a mobilização e participação social em relação ao projeto propiciou um claro contraste com o discurso vitimizado dos principais meios de comunicação. A radicalidade da discussão permitiu que a problemática comunicacional se transformasse em um tema de debate público e cotidiano (POSTOLSKI, 2013).

A circulação dos discursos contrários à monopolização da comunicação e as transformações da psicosfera preexistente a partir da ampliação do debate público sobre o tema já representam uma importante reorganização do espaço e de seus usos e aponta para um novo conjunto de possibilidades no que se refere às dinâmicas da comunicação no território argentino.

A judicialização da disputa durou até 29 de outubro de 2013, quando a 
Suprema Corte argentina declarou a plena constitucionalidade da Lei de Serviços de Comunicação Audiovisual (AHARONIAN, 2013). Há avanços também na decisão da Corte, como o reconhecimento de que o Estado tem interesse inquestionável na regulação dos meios, por exercerem um papel relevante na formação do discurso público; e da fundamentação da nova regulação como a garantia da pluralidade e da diversidade de vozes, para além das tecnologias envolvidas na transmissão. Serão analisadas, a seguir, as condições normativas possibilitadas pela aprovação desse marco legal à comunicação audiovisual na Argentina. 


\section{capítulo 2}

As transformações normativas para a democratização da comunicação audiovisual na Argentina 


\title{
2. As transformações normativas para a democratização da comunicação audiovisual na Argentina
}

\begin{abstract}
los problemas y las posibilidades de un espacio audiovisual latinoamericano pasan por unas políticas audiovisuales capaces de hacerse cargo de lo que los medios tienen de, y hacen con, la cultura cotidiana de la gente [...]. Ello exige que esas políticas partan de, y se centren, no en declaraciones de intenciones, sino en un serio reconocimiento de los problemas y en un análisis preciso de las posibilidades. Unas políticas no generalistas y dirigidas al abstracto público de las declaraciones de intención, sino diversificadas y dirigidas a los gobiernos y a los empresarios del sector audiovisual, a los usuarios y a las organizaciones sociales, a los profesionales del sector y a los investigadores, a los organismos internacionales y a las universidades.
\end{abstract}

Jesús Martín-Barbero, Las transformaciones del mapa (1999).

Las nuevas legislaciones [...] expresan un tipo de política estatal que se articula com el funcionamiento y la revalorización de la democracia em casi todo el continente.

Rodolfo Gómez, Políticas públicas de comunicación y Estados capitalistas en América Latina (2013).

As disputas por uma outra organização da comunicação no espaço passam por transformações nas condições técnicas, normativas e de organização dos lugares para a produção e circulação de informações. Como afirma Castillo (2017b, p. 6),

reconhecer a centralidade do papel das normas nas mais variadas formas de usos do território, tanto aqueles que efetivamente se realizam, com maior ou menor dificuldade, quanto os que permanecem em latência, isto é, não conseguem ou são impedidos de se realizar, é imprescindível para a construção de um conhecimento crítico e, ao mesmo tempo, operacional.

Essa questão se coloca para as normas sobre os serviços de comunicação. Há que se compreender o papel das normas e das técnicas em criar, estabelecer ou transformar as condições para os usos do território (SANTOS, 2006, p. 23). Segundo Antas Jr. (2005, p. 61), “a norma, para a geografia, pode ser vista como o resultado da tensão e/ou da harmonia entre objetos e 
ações que constituem o espaço geográfico". Para o autor, há normas cujo exame nos fornece subsídios profícuos sobre a dinâmica territorial de um determinado período (ANTAS JR, 2005, p. 71). Os diferentes sentidos das políticas de comunicação ao longo do tempo acompanharam distintas condições normativas para a organização da produção e da circulação de informações no território argentino.

As normas compõem - mas não esgotam - o conjunto de ações e materialidades com o sentido das diferentes políticas de comunicação ao longo do tempo. Daí a afirmação da importância da investigação da "profusão de normas e o protagonismo do território para a elucidação das implicações sociais, econômicas, políticas e culturais, em todas as escalas geográficas" (CASTILLO, 2017b, p. 7).

A análise das condições normativas deve ser compreendida em seus limites: como afirma Marino (2016b, p. 15), não podemos cair na armadilha de discutir somente o instrumento que a norma constitui e não dar conta do conjunto de ações que compõem a política de comunicação. Comentando a lei de comunicação equatoriana, Reyes (2017, p. 265) lembra que "nenhuma lei muda a realidade per se. Mas a lei é um fator que possibilita, ou pelo contrário cria obstáculos e pode até anular, as transformações sociais, sendo um elemento muito significativo".

O próprio espaço, por seu conteúdo técnico, é regulador e regulado: "normas gerais são diversamente eficazes, segundo os lugares, pois o conteúdo técnico e informacional de cada área tem um papel fundamental no comportamento dos agentes" (SANTOS, 2006, p. 230). Daí a necessidade compreendermos conjuntamente as condições normativas com as condições técnicas e de organização, atreladas às desigualdades da formação socioespacial.

As condições normativas da comunicação na Argentina estabelecidas no marco da Lei de Serviços de Comunicação Audiovisual (LCSA, lei n. 26.522/2009), fazem parte de um movimento mais amplo da totalidade latino- 
americana. Desde o início da década de 2000, um conjunto de políticas de comunicação foi discutido, disputado e realizado em diversos territórios latinoamericanos, tratando, sobretudo, de uma nova regulação da comunicação nesses países e do fomento a novos agentes comunicacionais. O território argentino foi onde essa disputa teve maior protagonismo ${ }^{26}$, e grande ênfase foi dada ao papel do novo marco normativo.

Pretende-se, aqui, compreender a trajetória recente das normas de comunicação na Argentina e a reorganização normativa consolidada no marco da LCSA. Em seguida, considerando a América Latina como totalidade, busca-se analisar as aproximações e distanciamentos entre as normas argentinas e a reorganização normativa da comunicação em outros países, tais como Bolívia, Equador, Uruguai e Venezuela. Também será analisada, brevemente, a situação de países como Chile, Paraguai e Brasil onde essa agenda não avançou.

${ }_{26}$ "O caso argentino se tornou central tanto pela intensidade das mudanças implementadas pela ação do Estado, desde 2008 em diante, como pela dinâmica do mercado e o desenvolvimento que a mudança tecnológica contribui e condiciona" (MARINO, 2016b, p. 15). 


\subsection{As normas argentinas para a comunicação e o combate à violência da informação}
Eu era presidente da comissão de comunicações no ano de 1986, e um dia recebi um chamado de Magnetto [proprietário e diretor executivo do grupo Clarín] que me convidou a tomar um café. E ele me disse que era necessário revogar o artigo 45 da [lei de] radiodifusão. Porque eles estavam, naquele momento, desejando obter a rádio Mitre e ampliar o processo de concentração da mídia, e esse artigo proibia isso.

Depoimento do parlamentar Leopoldo Moreau no Diário Uno, 30/10/2013.

A promulgação da Lei dos Serviços de Comunicação Audiovisual alcançou uma transcendência social atípica para um texto normativo.

Glenn Postolski, Artilugios, viabilidad y voluntad en torno a la aplicación de la Ley de Medios (2013).

\subsubsection{Normas para um modelo concentrado e privatista}

Na Argentina, as últimas décadas do século XX foram marcadas por políticas de comunicação privatistas, que deram forma ao sistema comunicativo de alta concentração de propriedade e espacial, voltado à mídia comercial. A ditadura militar de 1976 a 1983 foi marcada por uma distribuição desigual de renda, pela perda de rendimentos e por benefícios ao capital concentrado (MASTRINI; BECERRA, 2006), além de um forte processo de intervenção e controle dos meios de comunicação, com intensa repressão e censura:

\footnotetext{
Foram oito anos nos quais não se respeitaram - entre tantos outros direitos o direito à informação, o direito à comunicação nem a livre expressão. Oito anos durante os quais a sociedade foi vítima das perigosas relações que se deram entre os meios e a ditadura. Relações que complementaram a política comunicacional - parte da política cultural - que incluiu negócios, geração de consenso, censura, controle, repressão (POSTOLSKI; MARINO, 2009, p. 187).
}

Nessa época foi gestado o marco normativo das comunicações que, com pequenas alterações, esteve vigente até 2009: o decreto-lei nº 22.285/1980, imposto durante o governo de Videla. Segundo Postolski e Marino (2009, p. 179), a norma foi desenhada pelo regime autoritário em conjunto com as principais entidades empresariais do setor: a Associação de Radiodifusoras Privadas 
Argentinas (ARPA) e a Associação de Telerradiodifusoras Argentinas (ATA). Desse modo, a norma atendia os interesses do Estado censor e das grandes empresas de mídia. Este marco normativo acompanhou um conjunto de instituições nãodemocráticas, sob comando militar, que controlavam desde as concessões para rádio e televisão até o conteúdo. Entre essas instituições, destaca-se o Comitê Federal de Radiodifusão (Comfer), que permaneceu existente até o novo marco legal de 2009.

Desde a redemocratização, houve uma série de disputas e de projetos para mudança desse marco normativo - a maioria deles ainda na década de 1980. Durante o governo Alfonsín (1983-1989), foi criado um Conselho para a Consolidação da Democracia (Cocode), a quem foi solicitado um projeto de lei de radiodifusão democrática (SEGURA, 2011). Entre as características principais do projeto elaborado, constava o seguinte:

É estabelecido o direito à informação como complemento da liberdade de expressão. Propõe-se uma autoridade de aplicação com um órgão colegiado, assessorada por um conselho que inclui uma quantidade significativa de setores sociais. Conselhos regionais como autoridade de aplicação local, Descentralização da outorga de frequências. Criação de um sistema audiovisual governamental e outro estatal. Possibilidade para que qualquer pessoa jurídica possa acessar meios audiovisuais, permitindo iguais tempos de publicidade tanto para aqueles que pertencem a sociedades comerciais quanto para as sem fins lucrativos. Criação de um instituto de pesquisa e promoção audiovisual. Cria-se a figura do defensor público. É estalecido um limite aos meios gráficos (só pode haver 33\% dos votos e do capital dos meios audiovisuais na mesma área de cobertura principal da publicação gráfica). Redes que não envolvam mais de 5 emissoras são permitidas, mas as emissoras comprometidas não podem cobrir mais de 30\% de sua emissão diária com material dessa procedência. Porcentagens obrigatórias de produção são estabelecidas: $15 \%$ nos dois primeiros anos e $25 \%$ nos anos seguintes. É permitido que emissoras não-autorizadas no momento do sancionamento da lei possam solicitar sua regularização à autoridade de aplicação (COCODE apud COM, 2009, p. 207, tradução nossa).

Todavia, uma articulação de donos de meios de comunicação privados 
- organizados na Comissão Empresarial de Meios de Comunicação Independentes (CEMCI) e liderados pelo grupo Clarín - pressionou legisladores para evitar a aprovação e sanção da lei, afirmando que a mesma constituía um ataque à liberdade de expressão (SEGURA, 2010), em um processo semelhante ao da disputa posterior pela aprovação da Lei de Serviços de Comunicação Audiovisual, em 2009.

A manutenção do marco regulatório da ditadura militar foi sustentada, nos anos seguintes, pelo predomínio do neoliberalismo - sobretudo na década de 1990 - e com o poder das grandes empresas em fazer valer seus interesses, difundindo a ideia de que a melhor lei de comunicação "é a que não existe" - como afirmou um diretor da Sociedade Interamericana de Imprensa (CASANOVA, 2014). A agenda geral de desregulação imposta naquele momento "abriga oportunidades mais fecundas para os agentes da globalização. [...] esse sistema de ações significa, certamente, uma neo-regulação que impõe uma rigidez alheia aos Estados-nação" (SILVEIRA, 1997, p. 41). Essa agenda de regulações sob demanda das grandes empresas de comunicação está presente em muitos dos governos de viés neoliberal, como será visto adiante.

No governo de Carlos Menem (1989-1999), as primeiras privatizações nas comunicações (BARANCHUK, 2009) já apontavam para uma exacerbação do modelo privado-comercial. Na primeira metade da década de 1990, ainda sob a vigência do marco normativo da ditadura na comunicação, predominaram: os lobbies empresariais permanentes, que tiveram sucesso em adaptar a legislação às novas técnicas seguindo seus interesses e em possibilitar a entrada de capitais estrangeiros; a reconfiguração dos sistemas técnicos de comunicação, com incipiente convergência tecnológica e agregando novos agentes empresariais, como as companhias detentoras das empresas privatizadas; o exercício de controle do sistema por um organismo não democrático e sem recursos para seu corpo técnico; e a restrição das capacidades de ação pública dos cidadãos ou grupos sociais, renegados à posição de consumidores e expectadores (ROSSI, 
2009, p. 257-258). Na mesma direção, o segundo governo Menem foi marcado pela intensa concentração privada da mídia e pela desnacionalização do setor de comunicação, além da ausência de debate público e de espaços de participação da sociedade na formulação de políticas, como contam Albornoz e Hernández (2009).

Na transição de século, período de crise e grande instabilidade no país, não houve avanços na democratização da comunicação. O governo de Fernando de la Rua (1999-2001) manteve o "liberalismo comunicacional" - sequer houve tentativas de se democratizar a comunicação (LEIVA, 2009b). As linhas de ação do governo Duhalde (2002-2003) foram na defesa da propriedade e da posição de mercado dos principais meios privados (BALADRON, 2009, p. 338-339).

O governo de Néstor Kirchner (2003-2007) foi marcado pela manutenção de aspectos centrais da política comunicacional, com poucos avanços concretos. Apesar de pequenas reformas à norma de 1980, não houve mudanças significativas no marco regulatório da comunicação audiovisual, e algumas ações do governo beneficiaram a atuação e a manutenção da concentração dos grandes grupos de comunicação. A boa relação do governo com os principais grupos privados de comunicação marcaram uma situação distinta do que viria a ser o governo de Cristina Fernández de Kirchner. Becerra (2015) e Califano (2009) apontam que, sob a política da recuperação econômica e a defesa da economia interna, houve uma estratégia defensiva do setor, com as políticas protegendo interesses das grandes empresas em atuação no país. Por outro lado, medidas como o fortalecimento da comunicação pública - com destaque à criação do canal Encuentro, em 2005 - representaram avanços para a pluralidade da comunicação.

No governo de Cristina Fernández de Kirchner, a partir do já mencionado conflito do campo, passou a haver outra relação com os grandes meios, que agora atacavam o governo. A aprovação da LSCA como resposta a esse contexto é um dos elementos que marcam esta gestão no tema da 
comunicação, junto de outras políticas por vezes coincidentes, por outras distanciadas dos sentidos do marco normativo em questão (BECERRA; MASTRINI, 2017c). O foco da presente análise é compreender os sentidos das novas possibilidades à comunicação no território argentino nesse novo evento geográfico que acompanha a aprovação desse marco regulatório e o conjunto de políticas associadas a ele.

\subsubsection{Novas condições normativas no marco da "Lei de Meios"}

Como visto no capítulo anterior, a partir das demandas e da atuação organizada de diversos agentes do movimento pela democratização da comunicação - articulados na Coalizão por uma Radiodifusão Democrática -, em convergência com interesses do governo de Cristina Fernández (2007-2015), foi aprovado em 2009 um novo marco regulatório para o setor: a Lei de Serviços de Comunicação Audiovisual (LCSA). Esse novo marco normativo será analisado sob dois aspectos: (1) as condições para o combate à violência da informação e aos monopólios midiáticos; e (2) as normas para a comunicação comunitária e pública e a promoção de novos agentes comunicacionais.

As novas condições normativas para o combate à monopolização e à propriedade cruzada de meios a partir dessas políticas englobam a Decisão Administrativa 221, que criou o Fútbol Para Todos e acabou com o monopólio da transmissão futebolística, e uma parte significativa da LSCA (26.522/2009). Essa lei criou a Autoridade Federal de Serviços de Comunicação Audiovisual (AFSCA), autarquia descentralizada com função de aplicar, interpretar e fazer cumprir a nova lei - que substituiu o Comfer, criado sob a ditadura para controle militar da radiodifusão.

A AFSCA possuía sete membros ${ }^{27}$ em seu diretório e contava com

${ }^{27}$ Dois membros (presidente e diretor) eram designados pelo Poder Exercutivo; três integrantes indicados pela Comisión Bicameral de Promoción y Seguimiento de la Comunicación Audiovisual, do parlamento, selecionados a partir da proposta dos blocos parlamentares, correspondendo um à maioria ou primeira minoria, um à segunda minoria e um à terceira minoria parlamentar; e dois integrantes da sociedade civil, propostos pelo Conselho Federal de Comunicação Audiovisual, devendo um deles ser um acadêmico representante das faculdades ou carreiras de ciências da informação, ciências da comunicação ou jornalismo

88 | As transformações normativas para a democratização da comunicação audiovisual na Argentina 
participação social e representação da oposição. A orientação política do diretório dependia da composição dos representantes e da situação conjuntural, sem que o governo tivesse maioria garantida a priori ${ }^{28}$. Conforme entrevista realizada em 2015, o sentido da atuação do organismo envolveria garantir a efetivação da nova regulação, promover novos atores sociais na comunicação e mediar conflitos entre canais de rádio e televisão, buscando adequar o espectro para permitir a permanência de uma pluralidade de atores ${ }^{29}$. A instituição era responsável, ainda, por adequar os meios já existentes à nova legislação, além de oferecer capacitação técnica e financiamento de equipamentos para meios sem fins lucrativos longe dos principais centros urbanos.

$\mathrm{Na}$ LSCA (ARGENTINA, 2009c), as medidas antimonopolistas compreendem, sobretudo: (1) reservas do espectro radioelétrico para comunicação não-comercial (artigo 89); e (2) limites de quantidade de licenças de canais e imposição de restrições de audiência (artigo 45). Ganharam centralidade, a partir da promulgação da lei, as normas referentes à distribuição de licenças para operação no espectro radioelétrico ${ }^{30}$, bem público por onde trafegam as ondas de rádio e televisão aberta. Nesse entendimento, ter reservas ou impor limites de propriedade são estratégias para uma distribuição menos concentrada das concessões de uso desse espectro. Em relação ao segundo ponto das medidas antimonopolistas, os limites estabelecidos (Quadro 2) contemplam a rádio, televisão aberta e televisão a cabo paga, em diferente situação para alcance nacional e local. No caso da TV a cabo havia, ainda, a limitação de um máximo de $35 \%$ do total da audiência ou dos assinantes.

de Universidades Nacionais.

28 Entrevista de Eduardo Rinesi ao autor, em janeiro de 2016 em Buenos Aires. Rinesi é doutor em filosofia e professor universitário, ex-reitor da Universidad Nacional de General Sarmiento e foi integrante do diretório da AFSCA de 2014 até a dissolução da entidade pelo presidente Mauricio Macri.

29 Entrevista de Fernando Torillate, Diretor de Comunicação da AFSCA, ao autor, em março de 2015.

30 Este tema será melhor explorado no capítulo 3. 
Quadro 2: Combate à monopolização na Lei de Serviços de Comunicação Audiovisual (26.522/2009) - limites à concentração de licenças (artigo 45)

Limites - alcance nacional

1 licença de serviços de comunicação audiovisual via satélite - excluindo, a partir de então, a possibilidade de qualquer outro tipo de licença;

Até 10 licenças de serviços de comunicação audiovisual além de um sinal de conteúdos, quando se tratar de radiodifusão sonora, televisiva aberta ou por assinatura com uso do espectro radioelétrico;

Até 24 licenças, quando se tratar de exploração de serviços por assinatura com vínculo físico em diferentes localizações, sem ultrapassar o alcance de $35 \%$ do total de habitantes ou de assinantes do serviço nacionalmente.

Os prestadores de serviços de TV por assinatura não poderão ser titulares de outros sinais que não sejam o de geração própria.
Limites - alcance local

1 licença de radiodifusão sonora AM;

1 licença de radiodifusão FM ou até 2 licenças quando houver mais de 8 na área primária de serviço;

1 licença de radiodifusão televisiva por assinatura, sempre que o solicitante não for titular de licença de televisão aberta;

1 licença de radiodifusão televisiva aberta, sempre que o solicitante não for titular de licença de televisão por assinatura;

Em nenhum caso, a soma do total de licenças outorgadas na mesma área primária serviço poderá exceder 3 licenças.

Elaboração própria. Fonte: Argentina (2009c, art. 45).

As reservas previstas do espectro radioelétrico contemplam 33\% para organizações sem fins lucrativos, promovendo a comunicação comunitária; uma frequência $A M$, uma FM e uma de televisão para povos originários, onde estejam presentes; uma frequência de televisão aberta e uma de rádio para Universidades nacionais, em suas sedes, podendo autorizar mais frequências para fins culturais ou educativos quando demandado pelas universidades; e reservas para o Estado em suas diferentes escalas.

A partir das novas regras, a AFSCA deveria conduzir um processo de adequação dos meios existentes. No entanto, desde a aprovação da lei, o Grupo Clarín judicializou o tema, interpondo medidas judiciais para questionar aspectos da norma (Quadro 3). Segundo Sel (2013, p. 155-156), logo após a aprovação da lei na Câmara de Deputados - por 147 votos favoráveis, 4 contrários e 1 abstenção - o grupo iniciou esse processo com medidas cautelares. 


\section{Quadro 3: Principais momentos da judicialização da LSCA na disputa com o Grupo Clarín \\ Data Ações do Clarín e aliados / Encaminhamentos judiciais Vigência da LSCA}

\section{Etapa 1: Judicialização da lei e disputa pela constitucionalidade}

2009 dez. Em medida cautelar, Grupo Clarín reclama a inconstitucionalidade Vigente parcialmente (exceto dos artigos 161, 41, 45 e 48 da LSCA (perante a Cámara Nacional de artigos em questão). Apelaciones en lo Civil y Comercial).

2010 mar. Medidas cautelares apresentadas em Mendonza (por um

Vigência suspensa. deputado) e Salta (meios privados) pedem a suspensão da LSCA.

2010 A Suprema Corte de Justiça Nacional suspende a vigência das jun.-jul. cautelares das províncias.

Parcialmente vigente (devido à cautelar do Clarín).

2010 jul. a Encaminhamento sobre o prazo de duração da cautelar. Prazo é Vigente parcialmente. 2011 mai. definido em 36 meses (calculado para dezembro de 2013).

2012 Prazo de 36 meses é recalculado e data estabelecida é 07/12/12 (“7D”). Vigente parcialmente.

mai. Suprema Corte define que a lei não viola a liberdade de expressão.

2012 Judicialização da lei segue: Suprema Corte de Justiça demanda Vigente parcialmente. nov.-dez. decisão da primeira instância. Juíz Horacio Alfonso decide que lei é constitucional. Já a Cámara declara "inconstitucionalidade parcial" (de aspectos dos artigos 45 e 48).

2013 A Suprema Corte recebe o expediente e encaminha à Procuradoria Vigente parcialmente. jul.-ago. Geral da Nação, pedindo opinião, e realiza audiências públicas antes da decisão final.

2013 out. A Suprema Corte decide pela plena constitucionalidade da lei.

Vigente de forma plena.

\section{Etapa 2: Disputa judicial pela adequação do Grupo Clarín}

2013 nov. Grupo Clarín apresenta seu plano de adequação à lei, propondo ～Vigente; plano "voluntário" a 2014 fev. divisão em seis unidades para respeito aos limites de concentração. de adequação do Grupo Plano é admitido para análise pela AFSCA.

Clarín apresentado.

2014 out. Em outubro de 2014, a AFSCA reprova o plano de adequação

Vigente, mas judicializada: ao fim de "voluntário" do Grupo Clarín e institui uma adequação oficial. Ela é cautelar (com prazo de jan. 2015 suspensa judicialmente, por uma medida cautelar do grupo. $\mathrm{O}$ prazo final da cautelar é definido para o início de 2016. 2016) suspende adequação oficial do Clarín.

Fonte: Elaboração própria, com base em Marino (2016b).

O Clarín questionou os artigos que tratam sobre os limites das licenças, sua transferência, a concentração de propriedade e a adequação dos meios existentes. $O$ processo de judicialização pode ser entendido em duas 
etapas: a disputa pela constitucionalidade e plena aplicação e o conflito pela adequação do Grupo Clarín. A batalha judicial pela constitucionalidade plena da lei - e, por conseguinte, de sua vigência - perdurou por quatro anos, de sua sanção, em 2009, até outubro de 2013, quando a Suprema Corte declarou a constitucionalidade plena da LSCA (CHARRAS; BALADRÓN, 2014). A decisão estabeleceu um julgamento "sólido, argumentado, com citações à Comissão Interamericana de Direitos Humanos, às relatorias de Liberdade de Expressão da Organização dos Estados Americanos (OEA) e da ONU, à Comissão Europeia de Direitos Humanos, constitucionalistas [...] e uma doutrina jurídica ampla" (MARINO, 2016b, p. 23, tradução nossa). Em uma dessas menções, a decisão reconhece que

\begin{abstract}
na sociedade atual, os meios de comunicação de massa, como a televisão, o rádio e a imprensa, têm um poder inegável na formação cultural, política, religiosa etc. de todos os habitantes. Se esses meios são controlados por um pequeno número de indivíduos, ou por apenas um, se está, na verdade, criando uma sociedade na qual um pequeno número de pessoas exerce 0 controle sobre a informação e, direta ou indiretamente, a opinião que o resto das pessoas recebe. Essa falta de pluralidade na informação é um sério obstáculo ao funcionamento da democracia. A democracia precisa do confronto de ideias, do debate, da discussão. Quando este debate não existe ou está enfraquecido porque as fontes de informação são limitadas, se ataca diretamente o principal pilar do funcionamento democrático (CSJN, 2013, p. 38, tradução nossa).
\end{abstract}

Findada essa etapa, se iniciou a disputa pela adequação do Clarín aos limites de propriedade da lei. Essa disputa perdurou de 2014 até o fim do governo de Cristina Fernández, sendo encerrada com as alterações que o governo de Mauricio Macri faria no marco normativo por decreto, em favor do Grupo Clarín $n^{31}$.

Em relação ao fomento à diversidade e pluralidade da informação audiovisual, há uma série de pressupostos da nova norma e de condições

$31 \quad$ Este tema será explorado no capítulo 5. 
instituídas por ela. Inicialmente, como destaca Albornoz (2014), a LSCA explicita, na nota correspondente ao artigo $1^{\circ}$, sua adesão aos objetivos de tratados internacionais sobre promoção de diversidade cultural e pluralidade, o que se reafirma em seu artigo $2^{\circ}$ :

O objetivo principal da atividade fornecida pelos serviços regulados na presente lei é a promoção da diversidade e da universalidade no acesso e a participação, o que implica em uma igualdade de oportunidades para todos os habitantes da Nação para acessar os benefícios de sua prestação (ARGENTINA, 2009C).

A LSCA parte da compreensão de que a comunicação é um direito humano, e não apenas um negócio (MORAES, 2013). Nesse sentido, há um reconhecimento da comunicação comunitária e um entendimento de que é necessário descentralizar a produção de informações e criar mecanismos de fomento e capacitação à comunicação sem fins lucrativos baseada nos lugares. A produção audiovisual comunitária é um fenômeno que surge no contexto da democratização político-cultural que viveu a América Latina nos anos 1980 e da introdução de importantes transformações tecnológicas nas formas produtivas e de comunicação (QUINTAR; GONZALEZ; BARNES, 2014).

Cabe registrar que há um amplo debate sobre o significado da comunicação comunitária e distinções com a comunicação popular e a comunicação alternativa - como encontrado, entre outros, em Peruzzo (2006, 2015), Yamamoto (2007) e Aranha (2010). Para a legislação argentina, emissoras comunitárias são atores privados que têm uma finalidade social e caracterizamse por ser geridas por organizações sociais de diversos tipos, mas sem fim lucrativo. Sua característica fundamental seria a participação da comunidade tanto na propriedade do meio como na programação, administração, operação, financiamento e avaliação. Seriam, portanto, meios independentes e nãogovernamentais (ARGENTINA, 2009c). Entendemos que essa concepção estaria associada a uma comunicação baseada nos lugares, ainda que não haja restrição 
de alcance geográfico na lei. Na mesma direção, a legislação equatoriana entende que os meios comunitários são aqueles cuja propriedade, administração e direção correspondem a coletivos ou organizações sociais sem fins lucrativos, a comunas, comunidades, povos e nações (ECUADOR, 2013).

As políticas de fomento a novos agentes comunicacionais locais especialmente ao privilegiar os espaços "opacos" da globalização (SANTOS; SILVEIRA, 2001) - enfrentam diversas adversidades, exigem um conjunto integrado de medidas e levam tempo para promover resultados efetivos. Entre as dificuldades enfrentadas estão a desigual distribuição de objetos técnicos adequados à transmissão de informações no território, a necessidade de formação técnica para a operação desses objetos e para a geração de conteúdo qualificado e atrativo à audiência, custos e oferta desiguais dos serviços necessários (entre grandes grupos empresariais e meios locais) e o financiamento - já que são, em sua maioria, meios não-comerciais.

As medidas previstas para efetivar essa pluralidade de vozes podem ser agrupadas entre: (1) criação de condições normativas para ampliar a circulação desses conteúdos; e (2) normas de fomento e financiamento de produção de conteúdos. Em relação à ampliação da circulação desses conteúdos, ganha destaque o estabelecimento de limites mínimos para veiculação de produtos audiovisuais - no caso da televisão aberta, as cotas são de 60\% para a produção nacional, 30\% de produtos próprios e 30\% de produtos locais independentes na programação emissoras privadas ${ }^{32}$. Também destacam-se ações ligadas ao fortalecimento da televisão pública33: as previsões mais

${ }^{32}$ As definições do artigo 65 da LSCA estabelecem regras distintas para meios privados e não estatais, para rádio e televisão.

33 O Título VII da Lei trata sobre os serviços de radiodifusão do Estado nacional, entre os artigos 119 e 144. Merece destaque, também, o Título VIII, sobre os meios universitários e educativos. Nos objetivos e obrigações dos meios estatais, nos artigos 121 e 122, há imperativos de garantia de cobertura desses meios em todo o território argentino, promoção da pluralidade e da regionalização, garantia do direito à informação, promoção da produção própria, difusão do audiovisual nacional, regional e latino-americano (ARGENTINA, 2009c). Conforme Linares (2014), embora não haja uma definição explícita sobre a atividade dos meios de gestão estatal como "serviço público" na lei, o Título VII traz a compreensão da função dos meios públicos desenvolvida na América Latina e disposta nos 21 Pontos para uma Radiodifusão Democrática, da Coalizão por uma Radiodifusão Democrática, que pleiteava: "los medios estatales deberán ser públicos y no

94 | As transformações normativas para a democratização da comunicação audiovisual na Argentina 
avançadas sobre o tema acompanharam a consolidação de canais estatais e educativos e culturais como Encuentro e Pakapaka. Como será visto adiante ${ }^{34}$, além de serem meios para a veiculação de programação independente, grande parte da produção audiovisual desses canais era concebida pelas equipes internas e executada em parceria com produtoras de audiovisual do país, selecionadas por editais ${ }^{35}$. Desse modo, os canais poderiam contribuir, também, para o fomento a novos agentes produtores, além de fornecer conteúdo audiovisual gratuito para novos canais regionais.

Já no que diz respeito ao fomento e financiamento da produção de conteúdos, destacam-se: a regulação da publicidade (ARGENTINA, 2009c, cap. VIII) e a previsão de transparência da distribuição da publicidade oficial para os meios (ARGENTINA, 2009c, cap. VI) - tendo em vista que esta é uma das principais fontes de financiamento da mídia; a criação de um fundo de fomento concursável para financiamento dos meios sem fins lucrativos, sob administração da AFSCA; o Programa Polos Audiovisuais Tecnológicos, que criou uma rede de financiamento de audiovisual para a regionalização da produção; a criação de um banco audiovisual de conteúdos e concursos de fomento para a televisão digital (SEL, 2013). Além disso, a legislação é considerada avançada em termos da radiodifusão comunitária, com ausência de limites geográficos e de potência dos meios comunitários (diferente da Venezuela e do Brasil) e garantia de possibilidade de financiamento aos meios, com possibilidade de apoio governamental (MOREIRA, 2013).

As cotas mínimas, acompanhadas de linhas de financiamento e das iniciativas de produção de conteúdos que buscam promover diversidade e regionalização, impulsionam (potencialmente) no médio e longo prazo o

gubernamentales. Deberán proveer una amplia variedad de programación informativa, educativa, cultural, de ficción y de entretenimiento garantizando la participación ciudadana y la atención a las necesidades de la población".

34 O tema será abordado no capítulo 4.

35 Conforme entrevista de Facundo Agrelo ao autor, realizada em março de 2015 em Buenos Aires. Agrelo era coordenador geral do canal público educativo Pakapaka. 
surgimento de novos agentes produtores de audiovisual. Segundo Borello (2013, p. 7), a política argentina no campo audiovisual tem evoluído também por meio da criação de novas demandas (como nos canais públicos) e de diversos esquemas de fomento à produção desconcentrada.

Essas novas condições normativas compuseram a agenda da luta por uma democratização da comunicação na América Latina. Além da LSCA ser um importante instrumento para a difusão de uma outra psicosfera - ao fazer circular a denúncia da monopolização da informação e amplificar as possibilidade de uma outra comunicação possível -, em suas bases consta a proposta de criar novas condições para a organização da comunicação na Argentina, mais plural e menos concentrada.

É importante constatar, no entanto, que essas novas condições não determinam os usos do território. Além da inércia dinâmica do território herdado (SANTOS, 2004), há um conjunto de relações de poder e disputas que seguem sua sanção, envolvendo a aplicação da lei e a alocação de recursos para o financiamento dos meios e para as políticas de promoção de novos agentes comunicacionais. 


\subsection{Aproximações e distanciamentos entre as políticas de regulação da comunicação na América Latina}

Gobiernos como los de Venezuela, Ecuador, Argentina y Bolivia han optado por marcar límites a la libertad de expresión y abrir fuego sin matices contra unos cuantos medios, o contra todos, a partir de marcos legislativos ya promulgados y/o en proceso.

Carlos Mesa (2012), vice-presidente da Bolívia na gestão neoliberal de Sánchez de Lozada e presidente do país entre 2003 e 2005.

A consolidação de outra comunicação possível, na América Latina, depende da reconstrução do espaço público, após décadas de submissão ao neoliberalismo, culminando em esvaziamento de poderes do Estado, privatização desenfreada e concentração midiática.

Dênis de Moraes, Vozes abertas da América Latina (2011).

Na década de 2000, surgiu um contexto de transformações políticas em diversos países da América Latina, com uma "virada" política à esquerda. Esse contexto político viabilizou um conjunto de ações voltadas a romper com a concentração da mídia e democratizar a comunicação. Isso se deve, em grande parte, aos ataques midiáticos dos conglomerados nacionais a esses novos governantes ${ }^{36}$. Essa ofensiva impulsionou o questionamento do modelo normativo que permitia a centralização do comando da comunicação em poucos agentes (SEL, 2009, p. 30).

Desse modo, após debates e disputas de diferentes características em cada uma das distintas formações socioespaciais latino-americanas, teve início um conjunto de transformações nas políticas de comunicação. Como no caso argentino, vários governos anunciaram um enfrentamento à concentração das indústrias de comunicação e a elaboração de políticas com a pretensão de democratizar os meios. O que se observou com a emergência dos governos progressistas, de diferentes matizes, é uma revalorização do papel que o Estado

36 Conforme Santander (2015, p. 158), ao governar e levar adiante as medidas que questionam, de alguma maneira, a ortodoxia neoliberal, esses governos enfrentaram uma oposição rígida e permanente dos principais meios de comunicação. Para o autor, esses governos têm em comum a experiência de fortíssimas tensões com as corporações midiáticas, e uma luta explícita político-comunicacional. Serrano (2011, p. 85-192) analisa diversos aspectos dessas "agressões informacionais" e da cobertura da mídia nesses governos. 
deve desempenhar na esfera econômica, tanto em processos de regulação e controle quando nos de fomento e incentivo da demanda (GOMEZ, 2013). Desse modo, ganham força em vários países políticas de combate aos monopólios da comunicação compreendendo a responsabilidade do Estado na regulação do setor para viabilizar maior pluralidade e diversidade entre os agentes produtores de informação.

Compreendendo a América Latina como uma totalidade, percebe-se que as mudanças na comunicação na argentina não se dão de forma isolada. A partir do movimento permanente de totalização, essas ações compõem o enfrentamento ao neoliberalismo no continente e fazem circular outras possibilidades de organização e uso do território. Na comunicação, o processo argentino se vincula a esse processo latino-americano, em que "pela primeira vez na história, a população mais ativa em organizações da sociedade civil encarou processos de debate e ação em torno das políticas públicas de comunicação, superando acordos 'não escritos' entre governos e donos de meios" (MARINO; MASTRINI; BECERRA, 2011, p. 34-35).

A elaboração de políticas antineoliberais de comunicação nesse novo contexto político da América Latina se deu em muitos países. Para Mastrini e Becerra (2017b, p. 15), uma agenda progressista para a comunicação

seria guiada por princípios que permitem alcançar uma maior participação da sociedade civil cem relação aos meios mais diversos. Para cumprir esse programa, a agenda das políticas de comunicação se vincula com os padrões internacionais de liberdade de expressão e respeito aos direitos humanos e ao direito à comunicação, com o estabelecimento e fortalecimento de meios públicos, o desenvolvimento de políticas de fomento à produção de conteúdo nacional e local, a implementação de limites à concentração de propriedade e a sanção de um marco regulatório democrático para os meios de comunicação.

A agenda pela democratização da comunicação nos governos populares latino-americanos envolveu transformações normativas mais 
significativas em quatro deles, além da Argentina: Bolívia, Equador, Uruguai e Venezuela. Na Venezuela, foi aprovada a "Ley Orgánica de Telecomunicaciones", ainda em 2000, revendo o regime de concessões. Em 2005, entrou em vigor a "Ley de Responsabilidad Social en Radio y Televisión" (Resorte), reformada em 2010 para abranger também a internet. Na Bolívia, foi aprovada a "Ley General de Telecomunicaciones, Tecnologías de Información Y Comunicación", em 2011. O Equador teve sua "Ley Orgánica de Comunicación" entrando em vigor mais recentemente, em 2013. O Uruguai aprovou sua "Ley de Radiodifusión Comunitária" em 2007 e promulgou no fim de 2014 sua "Ley de Servicios de Comunicación Audiovisual". Em três desses países, as transformações sucederam rupturas normativas com a promulgação de novas constituições - na Venezuela em 1999, na Bolívia em 2007 e no Equador em 2008.

Buscando as aproximações entre essas políticas, serão analisados os novos marcos normativos sob dois aspectos, como no caso argentino: (1) as ações para o combate à violência da informação e aos monopólios midiáticos; e (2) as políticas para a comunicação comunitária e pública e a promoção de novos agentes comunicacionais. Além disso, serão apontadas algumas formações socioespaciais onde a política de comunicação permaneceu em distanciamento desse evento latino-americano de renovação das leis de comunicação com sentido mais democrático e popular.

\subsubsection{Aproximações no combate à violência da informação e na promoção de novos agentes comunicacionais}

Uma dimensão importante dessas novas políticas é o entendimento de que a concentração de propriedade dos meios cria distorções para a liberdade de expressão de todos e que, nesse sentido, cabe, além de promover novas vozes, impedir a concentração econômica da comunicação - sobretudo considerando que grande parte dos meios de grande alcance funcionam sob concessões públicas. Trata-se, assim, de instrumentos de combate à violência da informação, como no caso argentino. 
$\mathrm{Na}$ Venezuela, as transformações normativas devem ser compreendidas no bojo das transformações da "revolução bolivariana" (MATEOS, 2017) e da grave tensão entre o governo bolivariano e empresas privadas de mídia ${ }^{37}$. A nova legislação, já mencionada, garantiu grande poder à Comisión Nacional de Telecomunicaciones (Conatel), que controla o espectro radioelétrico e as concessões. Para o combate à monopolização da comunicação, houve grande ampliação das concessões para comunicação comunitária, ainda que a legislação não crie reserva proporcional do espectro radioelétrico (MOREIRA, 2013). Não há referências diretas, na legislação, de limites à propriedade cruzada de meios (LED, 2013) ou outros mecanismos de combate aos monopólios - as novas políticas de comunicação são dependentes das decisões e da atuação da Conatel. A Lei de Responsabilidade Social no Rádio e na Televisão ("RESORTE") estabeleceu um marco normativo de responsabilidade aos meios e estabeleceu condições normativas para a regulação pelo Estado, reconhecendo a necessidade de democratizar a mídia e promover a diversidade e direitos, estabelecendo parâmetros para o "controle social" dos meios de comunicação (GARCÍA et al., 2012). A lei cria novas instâncias de acompanhamento (Diretório de Responsabilidade Social e Conselho de Responsabilidade Social), instrumentos de sanção às violações previstas e condições para diversas ações contra a monopolização da mídia no país.

O combate aos monopólios da informação no novo arcabouço normativo da Bolívia envolve a distribuição do espectro com reservas de 33\% para a comunicação estatal, 33\% para a mídia comercial, 17\% para canais comunitários e $17 \%$ para os povos indígenas originários campesinos, as comunidades interculturais e afro-bolivianas (BOLÍVIA, 2011). Há, também, uma rígida e explícita restrição à propriedade cruzada de meios. No caso das rádios, o limite é de uma licença para uma mesma área de serviço. No caso da televisão aberta, o limite é de uma licença de radiodifusão para uma mesma área de

37 O ápice dessa tensão na década de 2000 aconteceu durante curto golpe de Estado de 2002, que depôs o presidente Hugo Chávez por 48 horas, com apoio de grandes empresas de mídia (AHARONIAN, 2015). 
serviço - limitação que opera com relação a todos os acionistas das empresas de comunicação. Além disso, há proibições de concentração econômica, cartelização e práticas afins (art. 61). A Autoridad de Regulación y Fiscalización de Telecomunicaciones y Transportes (ATT) é responsável por fazer cumprir esses requisitos legais. O cenário midiático boliviano é, no entanto, menos concentrado ${ }^{38}$ - ainda que haja meios, sobretudo em rádio e televisão, que funcionam em lógica de rede, não há a configuração de controle monopólico ou oligopólico dos conteúdos comunicacionais (UNESCO, 2016, p. 43).

No Equador, a partir da Ley Orgánica de Comunicación, também houve uma distribuição proporcional do espectro, com reserva para a comunicação comunitária (34\%), estatal (33\%) e para a mídia comercial (33\%). A lei estabelece um limite rígido à propriedade cruzada - apenas uma licença de rádio AM, FM e de TV por pessoa física ou jurídica. A aplicação dessas exigências está a cargo do Consejo de Regulación y desarrollo de la Información y Comunicación (Cordicom). O conselho foi previsto com um pleno com cinco integrantes: o presidente, de indicação do governo; um representante dos governos autônomos descentralizados; um representante dos conselhos nacionais para a igualdade; um representante da defensoria e um da do conselho de participação cidadã e controle social ${ }^{39}$. Foi criada, também, uma Superintendencia de Información y Comunicación (Supercom), órgão que deveria aplicar sanções às violações dos meios $^{40}$. O sistema de meios é predominantemente privado e conta com a presença de diversos meios falidos que passaram à administração do Estado. $O$ processo de redistribuição das frequências da radiodifusão, previsto com a lei, só teve início em 2016, com um

38 Entrevista de Erick Torrico Villanueva e Bernardo Poma Ulo ao autor, em La Paz (Bolívia), em abril de 2017. Ambos são pesquisadores e ativistas do tema do direito à comunicação, atuantes na ONG Unir Bolívia.

39 Entrevista com Patricio Barriga ao autor, em julho de 2015, em Quito (Equador). Ele presidia do Cordicom.

40 Conforme entrevista de Hernán Reyes ao autor, essa divisão em dois organismos regulatórios e a atuação da Supercom nas sanções despertavam críticas e um entendimento distorcido do que propunha a nova lei. Outras críticas feitas à norma equatoriana dizem respeito a um artigo que busca proibir o "linchamento midiático" e abriria espaço para restrições à liberdade de expressão. A entrevista ocorreu em julho de 2015 em Quito (Equador). Reyes era, então, representante da sociedade civil no Cordicom. 
concurso de 1476 frequências (BOLÍVIA, 2011, p. 264; REYES AGUINAGA, 2017).

Na Lei de Serviços de Comunicação Audiovisual uruguaia, está previsto que o Estado deve agir para garantir a pluralidade e diversidade e combater a formação de oligopólios ou monopólios midiáticos; para tanto, há uma restrição de três licenças para serviços de radiodifusão aberta de rádio ou televisão ou mais de dois para serviços na mesma banda de frequências (AM, FM ou televisão) em todo o território nacional. Além disso, o total de assinantes de televisão por assinatura de uma empresa não pode superar $25 \%$ do total de assinantes no território nacional, ou 35\% em territórios onde existam outras autorizações ou licenças de menor alcance (URUGUAY, 2014). A lei de comunicação comunitária reserva, também, ao menos um terço do espectro, em cada localidade, à comunicação comunitária (limitando o espectro disponível aos grandes meios). A judicialização da lei, com o questionamento de diversos artigos, também dificultou o avanço à aplicação desses limites de concentração ${ }^{41}$. A lei estabelece a criação de um Conselho de Comunicação Audiovisual, independente, para acompanhamento e aplicação da lei. O sistema de meios é bastante concentrado, tendo três grandes grupos no controle da maior parte da comunicação do país (GÓMEZ GERMANO et al., 2017).

Em relação à promoção de novos agentes comunicacionais, há distintos processos em curso nos países aqui estudados. Na Venezuela, houve importante fortalecimento e criação de canais estatais - incluindo o canal internacional multiestatal Telesur. Criada em 2005, a Televisión del Sur (Telesur) é um canal multiestatal de iniciativa do governo venezuelano em conjunto com Cuba, Uruguai e Argentina, e com a participação posterior de Bolívia, Equador e Nicarágua. Segundo a própria Telesur (MENDES, 2008), o canal nasce de uma evidente necessidade latino-americana: contar com um meio que permita a todos os seus habitantes difundir seus próprios valores, ideias e conteúdos, livre

\footnotetext{
${ }^{41}$ Entrevista de Gustavo Gómez ao autor, em novembro de 2016 em Montevidéu (Uruguai). Gómez é um dos formuladores do marco legal, ex-assessor de comunicação do presidente José “Pepe” Mujica, e atualmente é diretor executivo do Observacom (Observatorio Latinoamericano de Regulación, Medios y Convergencia).
} 
e de forma igualitária. Despontaria, assim, como uma alternativa capaz de fazer frente ao discurso único difundido pelas grandes corporações de mídia com base nos Estados Unidos e Europa.

A partir das novas normas venezuelanas, há a obrigação aos concessionários de que veiculem um mínimo de sete horas diárias de programas de produção nacional, das quais quatro horas devem ser de produção independente. Também há uma exigência para que, durante o horário nobre, um mínimo de três horas seja reservado a programas de produção nacional, metade desse período com produção independente (VENEZUELA, 2011). Três horas diárias estão destinadas, ainda, à programas culturais, educativos informativos, de opinião e recreativos dirigidos à infância e adolescência (GARCÍA et al., 2012). Segundo Moraes (2011, p. 118), o governo venezuelano oferece capacitação técnica, faz doações de equipamentos com técnicas mais eficientes e cria linhas de financiamento. Foi criado um Sistema Nacional de Meios Alternativos e Comunitários. De fato, ao analisar o percentual de meios comunitários aprovados nos primeiros anos que seguiram essas novas políticas venezuelanas, houve um crescimento de 270\% até 2011 (MOREIRA, 2011, 2013). Todavia, conforme Moreira (2013, p. 220), os meios comunitários ainda apontam críticas relativas à "ausência de critérios claros para a distribuição de recursos públicos para as emissoras, à inexistência de espaços de cogestão, como um conselho de Comunicação com participação dos meios comunitários, e à falta de continuidade da política estatal".

No Equador, a partir da nova Ley Orgánica de Comunicación, houve, como visto, uma reserva proporcional do espectro radioelétrico. Também surgiram critérios buscando a igualdade de oportunidades de acesso à publicidade oficial. Em relação ao conteúdo audiovisual veiculado, há uma exigência de $60 \%$ ser produção nacional, com 10\% de produção local independente. Para a comunicação estatal, foram criados os canais Ecuador TV e os jornais El Ciudadano e El Verdadero. Estão previstas, na legislação, ações 
afirmativas para fomentar a comunicação comunitária, como crédito preferencial para a criação desses meios e para a compra de equipamentos, isenções de impostos para a importação de equipamentos e acesso à capacitação para a gestão técnica, administrativa e de comunicação (ECUADOR, 2013). Essas iniciativas ficam sob responsabilidade do Conselho que aplica e fiscaliza a lei (Cordicom). A partir do Plan Nacional del Buen Vivir 2013-2017 (REYES AGUINAGA, 2017, p. 263), se buscou incentivar idiomas dos povos originários na esfera midiática, conteúdos que fortalecessem a identidade plurinacional e conteúdos que buscassem erradicar estereótipos e discriminações das mais diversas.

Na Bolívia, além da reserva de espectro incluindo povos originários e afrobolivianos, Gómez e Ramos-Martín (2014) destacam três iniciativas da nova política para a comunicação comunitária: (1) o programa de apoio e reativação da Rede Mineira de Rádio e Televisão por satélite da Bolívia; (2) o sistema nacional da rede de Rádios dos Povos Originários (RPO), com 60 emissoras de caráter indígena-sindical; e (3) a criação do Sistema Plurinacional de Comunicação, vinculado à Agência Plurinacional de Comunicação, para o tratamento, a difusão, a recepção e a distribuição de conteúdos produzidos pelos povos originários. Houve regulamentação, via decreto, da comunicação comunitária rural (MORAES, 2011, p. 118), com a isenção dos custos de licenciamento e uso das frequências. A comunicação estatal também foi reorganizada, e surgiu um novo jornal impresso (“Cambio"). Segundo entrevista ${ }^{42}$, nesse processo de expansão da comunicação comunitária, foram ampliadas as vozes dos movimentos indígenas e de trabalhadores que compõem o Pacto de Unidad, aliança de movimentos e organizações de base que inclui a Confederação Sindical Única de Trabalhadores Campesinos da Bolívia (CSUTCB), a Confederação Nacional de Mulheres Campesinas Indígenas Originárias da Bolívia "Bartolina Sisa” ("Bartolinas"), a Confederação Sindicalista de Comunidades Interculturais da Bolívia (CSCIB,

42 Entrevista de Erick Torrico Villanueva e Bernardo Poma Ulo ao autor, em La Paz (Bolívia), em abril de 2017. Ambos são pesquisadores e ativistas do tema do direito à comunicação, atuantes na ONG Unir Bolívia. 
"Interculturales"), a Confederação de Povos Indígenas da Bolívia (CIDOB) e o Conselho Nacional de Ayllus e Markas del Qullasuyu (Conamaq) - movimentos sociais importantes ao projeto popular que conquistou a presidência com Evo Morales.

O Uruguai aprovou uma lei da comunicação comunitária em 2008 (URUGUAY, 2008), antes de uma mais geral dos serviços de comunicação audiovisual. Nas normas uruguaias, há uma reserva de espectro de pelo menos um terço à comunicação comunitária. Também ficaram estabelecidas cotas nacionais de ao menos $60 \%$ da programação de cada serviço de televisão comercial ou pública. A LSCA uruguaia deixou em aberto a porcentagem da programação local para meios comerciais para a regulamentação da lei. Há cotas, ainda, de 30\% da programação nacional que devem ser realizadas por produtores independentes, não podendo concentrar em um mesmo produtor mais que $40 \%$ desse total; duas horas por semana deverão ser dedicadas a estreias de filmes, sendo metade de produção independente; duas horas por semana deverão conter programas de agenda cultural (URUGUAY, 2014). O Uruguai foi o primeiro país a estabelecer regras para a comunicação comunitária sem limites técnicos prévios, com possibilidade de acesso a recursos econômicos para sua sobrevivência e a reserva de espectro (GÓMEZ GERMANO, 2011).

As políticas para a comunicação dos países latino-americanos aqui analisadas convergem no sentido de unir medidas de combate à monopolização da informação e de promoção de novos agentes comunicacionais nacionais e regionais. Uma orientação comum dessas políticas é ampliar a produção e circulação de informações a partir dos lugares até então menos expressivos, em geral com menor densidade técnica, menos conectados às redes globais informativas ou que participavam dessas redes sobretudo como receptores de informações comandadas alhures, carregadas de sentidos alheios. 


\subsubsection{Distanciamentos da agenda progressista para a comunicação na América Latina}

Apesar das transformações em diversos territórios latino-americanos, outros países do continente, ainda que com governos de viés popular, não avançaram em marcos normativos com sentido democrático e promotores do direito à comunicação. É o caso do Chile, onde durante os anos da coalizão de centro-esquerda Concertación de Partidos por La Democracia não foram articuladas políticas claras para a comunicação comunitária e não só se manteve a concentração da imprensa escrita em grupos econômicos, mas a ação do Estado a fortaleceu a partir da publicidade estatal, da falta de apoio a meios alternativos e de uma legislação que permitiu a renovação preferencial das licenças de radiodifusão, "congelando" a distribuição do espectro (GÓMEZ GERMANO, 2011, p. 19). Apenas em 2010 foi aprovada uma lei de radiodifusão comunitária bastante restritiva quanto à potência e aos limites desses meios, a Lei n. 20.433/2010. A base do marco normativo está presente na Lei Geral de Telecomunicações de 1982 (OBSERVACOM, 2014).

O mesmo ocorreu no Paraguai, onde não foi realizada nenhuma ação no combate à concentração midiática. O marco regulatório básico é fundamentado na Constituição Nacional de 1992, que trata do espectro e da radiodifusão como serviços públicos, e na lei n. 642/1995, a lei de telecomunicações. Os meios comunitários são parcialmente reconhecidos no marco jurídico e normatizados por resoluções internas do órgão regulador, o Conatel. O diretório do órgão é todo indicado pelo governo, sem independência (OBSERVACOM, 2014). A concentração midiática no país é grave pois abrange grupos com atuação e interesses em outros setores econômicos importantes (GÓMEZ GERMANO, 2011).

No Brasil, o marco legal é antigo, permissivo com a concentração midiática e ineficaz - "nem mesmo as poucas provisões legais existentes são aplicadas de fato" (INTERVOZES, 2017b). A base do marco regulatório vigente é o 
Código Brasileiro de Telecomunicações de 1962. As principais características que configuraram a organização das comunicações na formação socioespacial brasileira foram: (1) o mercado extremamente concentrado; (2) a predominância do setor privado; (3) a ausência de regulamentação; e (4) a forte dependência em relação aos conteúdos e técnicas dos principais conglomerados midiáticos e agências globais de notícias. De fato, desde pelo menos os anos 1930, o modelo de radiodifusão adotado tem privilegiado a atividade privada comercial e favorecido a conformação de oligopólios midiáticos, em função da ausência de regulação (LIMA, 2011b). A democratização da comunicação é parte da agenda histórica dos movimentos sociais do país, sobretudo na redemocratização. Esses movimentos foram muito atuantes durante a última Assembleia Constituinte mas, para Brandt (2002, p. 124), o capítulo da Comunicação Social da Constituição Federal de 1988 "é resultado do lobby do empresariado, reforçado pelos interesses próprios dos congressistas. A análise cuidadosa de seus cinco artigos evidencia a vitória de uma visão liberal, defensora [apenas] da liberdade de expressão, em oposição ao direito à comunicação". Fato é que as medidas mais importantes ${ }^{43}$ permanecem sem regulamentação - o que preserva, na prática, o velho modelo (BOLAÑO, 2007, p. 21).

Cabe, aqui, detalhar as disputas por um novo marco normativo da comunicação nos governos progressistas do Partido dos Trabalhadores. Durante o governo Lula (2003-2010), apesar das diversas políticas de sentido progressista, as coligações para a garantia da governabilidade incluíram a entrega do Ministério das Comunicações para forças contrárias à regulação da comunicação, como o deputado Miro Teixeira"4, de 2003 a 2004, e o senador e exjornalista da Rede Globo Hélio Costa, de 2005 a 2010, representante dos interesses

43 Para Bolaño (2007), os dispositivos mais importantes previstos na Constituição e não regulamentados seriam: (1) a proibição do monopólio e oligopólio nos meios de comunicação (artigo 220, parágrafo 5); (2) a preservação das finalidades educativas, culturais e informativas; (3) a proteção à cultura regional através da garantia de regionalização da produção; (4) o estímulo à produção independente (artigo 221); e (5) a criação dos três modos complementares de exploração (privado, estatal e público) (artigo 223).

44 A esse respeito, conferir entrevista de 2011: "Miro Teixeira: 'Regulamentar a imprensa é intimidação'" [online] Disponível em: <http://bit.ly/10dnroz>. Acesso em 2015. 
da ABERT (Associação Brasileira de Emissoras de Rádio e Televisão). Essa situação, somada aos ataques sistemáticos dos grandes grupos de mídia a qualquer tentativa de regulação ou interferência no mercado midiático, trouxe várias derrotas a iniciativas para a democratização da comunicação. Conforme Lima (2011b), destaca-se que: (1) nada avançou em relação às rádios comunitárias, chegando até a aumentar a repressão sobre elas; (2) a transparência em relação aos sócios de emissoras de rádio e TV, demanda antiga, durou apenas de 2003 a 2007, quando as informações tornaram-se novamente indisponíveis por vias diretas e com acesso dificultado; (3) a definição do modelo de TV digital que, apesar de ter iniciado com um processo com participação da sociedade civil, após a atuação do Ministério das Comunicações a partir de 2005 em defesa dos interesses da TV Globo, culminou com a escolha do modelo japonês para a televisão digital, "tendo sido ignorada uma oportunidade histórica de se ampliar de forma significativa o número de concessionárias de televisão no país"; por fim, talvez a questão mais significativa, (4) o não estabelecimento de um novo marco normativo - uma lei geral de comunicação eletrônica de massa ou lei de serviços audiovisuais que combatesse a monopolização da informação e promovesse a garantia do direito à comunicação. Para o autor (LIMA, 2011b, p. 34), os avanços durante os dois governos Lula (2003-2010) se referem às seguintes iniciativas: na comunicação estatal e pública, a criação da Empresa Brasil de Comunicação (EBC) em 2007/200845; a convocação e realização da $1^{\text {a }}$ Conferência Nacional de Comunicação (CONFECOM), em 2009; o lançamento do Plano Nacional de Banda Larga (PNBL), em 2010; e, sobretudo, o início de um processo de regionalização das verbas de publicidade oficial. A publicidade oficial é uma das principais fontes de financiamento dos grandes meios e a principal dos meios alternativos, comunitários e regionais. Em 2003, essa verba era distribuída entre 499 veículos; em 2009, passou a atingir 7047, com manutenção relativa do montante total (LIMA, 2010c). O número de municípios cobertos cresceu de 182,

${ }_{45}$ A esse respeito, conferir Valente (2009).

108 | As transformações normativas para a democratização da comunicação audiovisual na Argentina 
em 2003, para 2184 em 2009. Essa regionalização da publicidade oficial “ficará na história como talvez a principal contribuição do governo Lula no sentido da democratização das comunicações" (LIMA, 2010b, n.p). São "avanços pontuais", como indicam Barbosa e Ekman (2017, p. 312).

A discussão de um novo marco regulatório para a democratização da comunicação, nos mesmos princípios dos demais países latino-americanos, foram o fundamento da primeira CONFECOM - um espaço participativo, com diversas etapas locais e a construção das políticas a partir das propostas da sociedade civil. As principais entidades patronais de comunicação boicotaram o processo $^{46}$, buscando deslegitimá-lo. A realização da Conferência em 2009 foi motivada por associações ligadas ao direito à comunicação, como a ABRAÇO (Associação Brasileira de Rádios Comunitárias), a Amarc Brasil (seção brasileira da Associação Mundial de Rádios Comunitárias), o Intervozes - Coletivo Brasil de Comunicação Social e o Centro de Estudos da Mídia Barão do Itararé, além de federações de sindicatos da área, como a FITTEL (telecomunicações) e a FITERT (radialistas) (CABRAL FILHO; COSTA, 2014). A I CONFECOM contou com mais de 6000 propostas encaminhadas, 700 aprovadas, tendo sido selecionadas 20 propostas prioritárias para a definição de um novo marco regulatório para as comunicações no Brasil. Boa parte dessas medidas foram inseridas no Plano Nacional de Direitos Humanos III (PNDH3, decreto no 7037, de 21 de dezembro de 2009). Após forte pressão da imprensa contrária ao plano - sob a acusação de "censura" -, cerca de cinco meses depois, um novo decreto (nº 7177 de 12 de maio de 2010) alterou o anterior, recuando em diversas conquistas da CONFECOM (LIMA, 2010C).

Paralelamente, a Secretaria de Comunicação Social da Presidência da República (SECOM), comandada pelo Ministro Franklin Martins, elaborou um pré-projeto de marco regulatório da organização e exploração dos serviços de

${ }_{46}$ "Seis entidades empresariais se retiraram da Comissão Organizadora: Associação Brasileira de Emissoras de Radio e Televisão (ABERT); Associação Brasileira de Internet (Abranet); Associação Brasileira de TV por Assinatura (ABTA); Associação dos Jornais e Revistas do Interior do Brasil (Adjori Brasil); Associação Nacional dos Editores de Revistas (ANER) e Associação Nacional de Jornais (ANJ)" (LIMA, 2009, s.p). 
telecomunicações e de radiodifusão, levando em conta o acúmulo de debates da Conferência e de outros seminários e eventos organizados por sua Secretaria (LIMA, 2011b, p. 39). Com um pré-projeto elaborado e a indicação de um Ministro das Comunicações do próprio Partido dos Trabalhadores - que inclui a democratização da comunicação entre suas bandeiras históricas - houve uma perspectiva de avanços para a regulação da comunicação no governo de Dilma Rousseff, eleita em 2010 - mas foram expectativas não concretizadas na comunicação audiovisual. Sem o avanço da pauta pelo governo, os movimentos e entidades elaboraram conjuntamente um Projeto de Lei de Iniciativa Popular para a democratização das comunicações no Brasil (conhecido popularmente como "projeto da Lei da Mídia Democrática") baseado nos 20 pontos prioritários da CONFECOM. Mas não houve correlação de forças que viabilizasse a colocação do tema com grande alcance no debate público e com incidência no Congresso Nacional.

Quanto aos avanços durante a gestão de Dilma Rousseff, cabe destacar a agenda ligada à internet. De um lado, o governo anunciou a ampliação das metas para a universalização da banda larga, devido aos tímidos resultados do Plano Nacional de Banda Larga; de outro, a defesa da aprovação do projeto de Marco Civil da Internet (uma "constituição" para a garantia de direitos da internet) construído pela sociedade civil. Ainda na gestão Lula, iniciaram-se consultas públicas para a formulação de um Marco Civil da Internet (SILVEIRAS, 2014). Com ampla participação da sociedade civil e pressão das entidades e movimentos sociais, o projeto elaborado defendia a neutralidade de rede ${ }^{47}$, a privacidade das informações dos usuários e a liberdade de expressão. O projeto foi sancionado e, posteriormente, regulamentado por decreto. No início do segundo mandato de Dilma (2015-2018), houve uma reorientação do discurso da presidência e do Ministério das Comunicações em defesa de uma "regulação

${ }_{47}$ "A neutralidade da rede refere-se a todas as informações que trafegam na rede mundial de computadores serem tratadas da mesma forma, sem discriminação de velocidade, permitindo o acesso igualitário às informações, não sofrendo limitação ou controle no envio, recebimento ou transmissão de dados" (SILVEIRAS, 2014, p. 126). 
econômica" do setor de comunicações. Mas, logo após o início do governo, a conjuntura no Congresso Nacional estava amplamente desfavorável a qualquer transformação nesse sentido, culminando no impeachment (em 2016) que depôs a presidenta - golpe que contou com importante apoio dos grandes meios de comunicação (CABALLERO, 2016; CAMPOS, 2016; GONÇALVES, 2018).

Apesar de alguns impulsos e iniciativas, durante os governos progressistas no Brasil não foram criadas as condições para encaminhar mudanças normativas à comunicação e para transformar o sistema de meios na direção da ampliação da pluralidade e da diversidade, dando continuidade a uma desregulação que é funcional aos grupos concentrados de comunicação (BOLAÑO, 2007, p. 105).

Já nos países onde o enfrentamento da questão conseguiu produzir importantes transformações regulatórias - Argentina, Uruguai, Bolívia, Equador e Venezuela -, há que se compreender que essas novas condições normativas são estabelecidas em pactos territoriais frágeis, que enfrentam poderosos interesses de agentes hegemônicos nacionais e transnacionais, além de diversas contradições internas dos processos políticos que os gestaram. Como revela Dênis de Moraes, baseando-se em Gramsci, o processo de modificação dos modos de pensar, nas crenças, nas opiniões e nos sentidos presentes na psicosfera hegemônica não ocorre mediante "explosões" rápidas, mas sim a partir de combinações sucessivas, num processo de transformação lenta e gradual (MORAES, 2011, p. 161-163). É nesse contexto que se compreendem essas novas normas - capazes de criar outras condições para a organização da comunicação nesses países, mas que se relacionam com condições técnicas, materiais e políticas complexas para sua aplicação. Nesse sentido, são investigadas, em seguida, políticas de reorganização das condições técnicas do território argentino necessárias para avançar na democratização da comunicação. 
112 | As transformações normativas para a democratização da comunicação audiovisual na Argentina 


\section{capítulo 3}

As redes técnicas no território argentino e as condições infraestruturais para a democratização da comunicação 


\section{As redes técnicas no território argentino e as condições infraestruturais para a democratização da comunicação}

O espaço geográfico permanece diferenciado apesar das redes de telecomunicações, e, além disso, essas redes contribuem para uma nova diferenciação do espaço.

Henry Bakis, Communications et territoires (1990).

A epígrafe acima, de Bakis, retoma a dialética entre os limites da universalização das redes em função da inércia das desigualdades herdadas no território e a potência das redes em criar novas diferenciações, ao invés de homogeneizar o espaço. Como lembra Castillo (1996, p. 47), "o grande volume de investimentos necessários para a implantação de novas tecnologias implica necessariamente na seletividade espacial - e também no aproveitamento de infraestruturas já presentes no território". A desigualdade e a seletividade da expansão das redes técnicas acompanham o desenvolvimento histórico, associadas às dinâmicas políticas e econômicas dominantes de cada período. Conforme apresenta Mattelart (2001, p. 15):

\footnotetext{
O século XIX prepara a lenta emergência de um novo modo de troca e circulação de bens, mensagens e pessoas, assim como de um novo modo de organização da produção. No decorrer desse século e, de forma especial, a partir de 1850 [...] um conjunto de invenções técnicas vai permitir o desenvolvimento de novas redes de comunicação. As formas históricas de implantação, segundo as quais cada um desses novos circuitos de troca vai se inserir nas diferentes sociedades, são anunciadoras de questões que continuarão a ser formuladas no século seguinte.
}

No caso do território argentino, Mattelart (1996, p. 214) resgata a relação entre a difusão das infraestruturas de circulação material, sobretudo a expansão das redes ferroviárias no século XIX e a difusão das infraestruturas das redes de comunicação. Ambas acompanham uma lógica extravertida, configurando uma alienação do território (ISNARD, 1978; SANTOS, 2009a). Com as redes telegráficas 
controladas por monopólios ingleses e, posteriormente, estadunidenses e reforçando, ainda, a concentração geográfica em Buenos Aires, Mattelart considera que "a supremacia ferroviária rima com o monopólio sobre os cabos e fios" (MATTELART, 1996, p. 214) no país.

Mais recentemente, no processo de globalização neoliberal, as possibilidades que acompanham a difusão seletiva pelo território de uma base técnica funcional à fluidez global da informação foram apropriadas sobretudo por um pequeno conjunto de agentes, especialmente grandes empresas (SANTOS, 2000). A tendência de expansão das novas tecnologias comandada pelas corporações é espacialmente concentrada e, assim, amplia desigualdades entre os espaços luminosos e opacos da globalização (SANTOS; SILVEIRA, 2001) e dificulta a circulação de informações ascendentes para grande parte do território.

Nos anos 1990, no contexto da adequação do território argentino ao projeto hegemônico da globalização, as reformas neoliberais acompanharam um processo de privatização "acelerado e implacável, já que antes da metade da década de 1990, já se encontravam privatizados canais de televisão, empresas de telefonia, petroquímicas, áreas de petróleo e gás e suas redes de distribuição, transporte aéreo, ramais ferroviários e as concessões de rotas de maior tráfego" (VELÁZQUEZ; GÓMEZ LENDE, 2005, p. 7). Essa reconfiguração da tecnosfera, acompanhada da psicosfera do discurso hegemônico da globalização, é marcada pela difusão seletiva de uma infraestrutura técnica fundamentada na lógica privada e comercial. Conforme Velázquez e Gómez Lende (2005, p. 11, tradução nossa),

A difusão da TV a cabo e por satélite durante os anos noventa na Argentina ocorreu no contexto da retirada do Estado e da consequente privatização dos meios de difusão. [...] Assim, de mãos dadas com a renovada lógica de mercado, houve um crescimento sustentado da oferta de televisão privada, simultaneamente à transformação da informação em mera mercadoria e à consolidação dos grandes grupos econômicos diversificados.

116 | As redes técnicas no território argentino e as condições infraestruturais para a democratização da comunicação 
Conforme Silveira (1999a, p. 216), o aprimoramento técnico e um barateamento dos sistemas de televisão por cabo e da transmissão por satélite são elementos que permitiram a ampliação das áreas de influência das empresas de comunicação argentinas. No final do século XX, enquanto na Capital Federal a televisão a cabo representava $42 \%$ do total de assistentes, no interior os índices eram mais significativos: 68\% em Rosário, 76\% em Neuquén, 77\% em Mendonça e $78 \%$ em Bahía Blanca. Essa situação viabilizava a presença dos conteúdos produzidos em Buenos Aires nesses lugares - reforçando a presença da metrópole no território nacional (SILVEIRA, 1999a, p. 217). Nas telecomunicações, a privatização dos anos 1990 acompanhou a formação de monopólios territoriais (SILVEIRA, 1999a, p. 141). Trata-se de uma renovação da base técnica para adequar seu funcionamento aos interesses dos agentes hegemônicos.

As técnicas podem ser analisadas sob diferentes perspectivas, conforme Zusman (2017, p. 50): como instrumento de dominação ou emancipação, como mediadora na construção de um tecido social e como constitutiva do meio geográfico. Nesse sentido, a perspectiva territorial da democratização da comunicação passa, também, pela universalização do acesso às bases técnicas. Para Ana Clara Torres Ribeiro (2000, p. 22), as ações nesse sentido devem abranger (1) a ampliação do acesso social às novas técnicas, (2) a defesa de usos transformadores dessas novas tecnologias e (3) novas normas que garantam o controle social dessas redes informacionais do atual período. A expansão das bases técnicas de suporte à fluidez informacional e a ampliação da densidade técnica dos espaços opacos da globalização compõem uma agenda política de grande importância para a democratização da comunicação, pois teriam a capacidade de estimular as condições para a produção e circulação de informações ascendentes e para a ampliação da densidade comunicacional dos lugares. Isso se daria em função da mediação crescente das técnicas na comunicação, da possibilidade de apropriação das novas técnicas por parte da maioria da população (SANTOS, 2000) e dos ganhos de escala do alcance das 
informações em circulação que são viabilizados por essas redes.

Se, durante os anos 1990, a lógica privatista das políticas de comunicação acompanhou a difusão de uma base técnica correspondente, agudizando a concentração geográfica e o modelo privado-comercial, no marco das políticas de comunicação analisadas neste trabalho também há diferenças na lógica de expansão das redes técnicas. Essas questões serão analisadas em três dimensões: em primeiro lugar, o espectro radioelétrico e as disputas por seu controle; em seguida, a tentativa de capitalizar outra infraestrutura para a televisão, por meio dos investimentos na Televisão Digital Aberta; em seguida, as iniciativas de expansão da base técnica que viabiliza a conexão à internet, englobando a questão da convergência tecnológica e o audiovisual ampliado. 


\subsection{Disputas pelo espectro radioelétrico: entre a razão neoliberal e "a reforma agrária do ar"}

Ninguém deve apropriar-se das frequências. As frequências radioelétricas pertencem à comunidade, são patrimônio comum da humanidade

Coalición por una Radiodifusión Democrática. 21 puntos (2004)

o mesmo modelo de concentração fundiária se espelhou para os meios de comunicação [...] Os primeiros grilaram terras públicas ou compraram terras de grileiros. Os últimos se apossaram do espectro eletromagnético por favorecimentos políticos e pelo poder econômico, ou ambos os casos. Na terra como na mídia estamos lidando com os mesmos problemas: a questão da propriedade, o seu uso social e quais modelos de desenvolvimento devem ser colocados em prática.

Silvio Mieli, em entrevista. Observatório do Direito à Comunicação (2012).

O espectro radioelétrico é o epicentro de uma parte significativa das disputas em torno da base técnica operacionalizada para circulação e consumo de informações e para o audiovisual em geral. Ele está, portanto, no centro dos interesses dos grupos concentrados de meios e dos agentes que defendem a democratização da comunicação. No território argentino, essas disputas acompanharam os conflitos em torno das políticas de comunicação no marco da Lei de Serviços de Comunicação Audiovisual de 2009.

Espectro de radiofrequências ou espectro radioelétrico são os nomes dados à parcela do espectro eletromagnético ${ }^{48}$ que é um bem público, de fruição limitada e que é, do ponto de vista do conhecimento tecnológico atual, passível de uso por sistemas de comunicação (TELECO, 2018). Ele corresponde à parcela do espectro situada, aproximadamente, entre os $3 \mathrm{KHz}$ e os $300 \mathrm{GHz}$, e é a parte mais usada para as telecomunicações sem fio (ALA-FOSSI et al., 2017, p. 42), englobando a radiodifusão.

48 Conforme Leiva (2012, p. 112), também são parte do espectro eletromagnético o infravermelho, a luz visível, os raios $\mathrm{X}$ e raios gama. $\mathrm{O}$ que as diferencia é a frequência e o comprimento da onda. Todas as ondas viajam quase na velocidade da luz, independente de sua frequência. Pool (2017, p. 5) lembra, ainda, que as ondas largas oscilam em baixa frequência, e as ondas curtas em frequência elevada. Entre os usos do espectro eletromagnético constam o sensoriamento remoto orbital (CASTILLO, 1999) - central para a possibilidade, no atual período da globalização, de conhecer o planeta extensiva e aprofundadamente, chamada de cognoscibilidade planetária por Santos (2000). 
Pode-se compreender o espectro radioelétrico como componente do espaço geográfico. Sua dimensão material seria marcada pelo conjunto sistêmico de objetos técnicos que compõem as condições infraestruturais necessárias para sua operação e para a circulação de informações por meio do espectro. De forma complementar, sua dimensão imaterial seria definida pelo conjunto de normas e políticas que regulam e orientam seu uso, além das informações que trafegam por meio dele. As disputas pelo acesso e uso do espectro radioelétrico compõem os conflitos de projetos de sociedade para a organização do espaço. Conforme Castillo (2017a, p. 647) a passagem das "possibilidades de circulação e de comunicação do estado de latência para o estado de existência e sua abrangência social dependem da política, do jogo de forças sociais que envolve o Estado, as empresas e as diversas formas de organização da sociedade civil".

Como afirma Leiva (2012, p. 114), o espectro radioelétrico é a base de tecnologias de comunicação tais como a transmissão de rádio e televisão, a telefonia móvel ou os radares, por exemplo, devido a sua capacidade de transportar este tipo de sinais. O espectro é organizado, dependendo do alcance de frequências, em bandas e sub-bandas, a partir da exigência de uma maior ou menor porção do espectro para o tráfego de uma quantidade de informação. Essas bandas são "divisões" do espectro, definidas por convenção, para vincular um ou outro tipo de serviços de comunicação. Seus usos principais são variados em função das características da banda de frequências (Quadro 4). 


\begin{tabular}{|c|c|c|c|c|c|c|}
\hline Banda & Frequência & $\begin{array}{l}\text { Comprimento } \\
\text { de onda }\end{array}$ & $\begin{array}{c}\text { Cobertura } \\
\text { potencial }\end{array}$ & $\begin{array}{l}\text { Custos de } \\
\text { equipam. }\end{array}$ & $\begin{array}{c}\text { Capaci- } \\
\text { dade }\end{array}$ & $\begin{array}{l}\text { Usos mais comuns } \\
\text { na comunicação }\end{array}$ \\
\hline $\begin{array}{l}\text { Frequência } \\
\text { baixa }\end{array}$ & $\begin{array}{l}3-30 \mathrm{KHz} \text { (VLF) } \\
30-300 \mathrm{KHz}(\mathrm{LF})\end{array}$ & $\begin{array}{c}100 \mathrm{~km} \text { a } 10 \mathrm{~km} \\
10 \mathrm{~km} \mathrm{a} \mathrm{lkm}\end{array}$ & ampla & baixo & baixa & $\begin{array}{l}\text { radionavegação, polícia, } \\
\text { emergências, militar, rádio }\end{array}$ \\
\hline $\begin{array}{l}\text { Frequência } \\
\text { média/alta }\end{array}$ & $\begin{array}{c}300 \mathrm{KHz}-3 \mathrm{MHz}(\mathrm{MF}) \\
3-30 \mathrm{MHz}(\mathrm{HF})\end{array}$ & $\begin{array}{l}1 \mathrm{~km} \text { a } 100 \mathrm{~m} \\
100 \mathrm{~m} \text { a } 10 \mathrm{~m}\end{array}$ & média & baixo & média & rádio, rádio amador \\
\hline $\begin{array}{l}\text { Frequência } \\
\text { muito alta }\end{array}$ & $\begin{array}{c}30-300 \mathrm{MHz} \text { (VHF) } \\
300 \mathrm{MHz}-3 \mathrm{GHz} \text { (UHF) }\end{array}$ & $\begin{array}{c}10 \mathrm{~m} \mathrm{a} \mathrm{lm} \\
\mathrm{Im} \mathrm{a} 100 \mathrm{~mm}\end{array}$ & média & médio & $\begin{array}{l}\text { média- } \\
\text { alta }\end{array}$ & $\begin{array}{c}\text { televisão, rádio, } \\
\text { comunicações móveis }\end{array}$ \\
\hline Micro-ondas & $3-30 \mathrm{GHz}$ (SHF) & $100 \mathrm{~mm}$ a $10 \mathrm{~mm}$ & reduzida & alto & alta & $\begin{array}{l}\text { comunicações móveis, } \\
\text { satélites, links de rádio, } \\
\text { redes de dados sem fio }\end{array}$ \\
\hline Milimétricas & $30-300 \mathrm{GHz}$ (EHF) & $10 \mathrm{~mm}$ a $1 \mathrm{~mm}$ & $\begin{array}{l}\text { muito } \\
\text { reduzida }\end{array}$ & muito alto & $\begin{array}{l}\text { muito } \\
\text { alta }\end{array}$ & $\begin{array}{c}\text { radioastronomia, } \\
\text { pesquisa }\end{array}$ \\
\hline
\end{tabular}

Elaboração: André Pasti. Fontes: Leiva (2012) e Ala-Fossi et al. (2017).

Como é possível observar em destaque, a banda de frequências muito altas é central à operação de rádio, televisão e às comunicações móveis - estas, também realizadas na banda de micro-ondas. O desenvolvimento tecnológico expande o uso do espectro eletromagnético como recurso, permitindo o uso de frequências mais altas e conseguindo a inserção de mais informação dentro de uma mesma banda (CASTILLO, 1999, p. 46).

Em um dado território, o espectro é de uso limitado, já que seus diferentes usos podem causar e sofrer interferências, caso não haja uma normatização. O espectro pode ser entendido, assim, como um recurso. Para Raffestin (1993, p. 225-226), um recurso é produto de uma relação, e só existe em função de um agente capaz de mobilizar certas técnicas. O espectro radioelétrico é um recurso finito que, do ponto de vista econômico é, também, um bem escasso e de uso excludente, intangível e renovável, que não é possível acumular nem armazenar, mas é possível comercializar (LEIVA, 2012, p. 115). A centralidade das disputas de controle do espectro explicam-se em função de ser um meio para o comando de um instrumento fundamental ao exercício do poder, a informação (CASTELLS, 2015; RAFFESTIN, 1993; RAMONET, 2013), e ao fato de ser limitado, ainda que não seja esgotável. 
A recomendação internacional (UIT, 2018) adotada de forma predominante no mundo para o ordenamento do espectro é a regulação estatal que estabeleça usos não-conflituosos do espectro, além de coordenação internacional em áreas de fronteiras. Isso implicou, em grande parte dos países, na compreensão do espectro como um bem público e, consequentemente, em processos de concessão pública do espectro, com diferentes características. No que tange à radiodifusão, como desenreda Martins (2014, n.p),

Tudo o que chega ao espectador por meio do rádio ou da televisão tem que passar pelo espectro eletromagnético, conjunto de ondas eletromagnéticas de diferentes frequências. O espectro é como uma estrada por onde trafegam carros. Assim como a estrada, esse espaço é limitado. Para utilizá-lo, é preciso obter uma concessão pública dada pelo Estado. Por isso, a transmissão de sons ou de sons e imagens, a radiodifusão, é um serviço público.

Essa compreensão está submetida a inúmeras disputas - que abrangem a quantidade e a qualidade do regramento estatal para a radiodifusão, o sentido, a transparência e o caráter das políticas referentes ao espectro mobilizando tensões entre uma lógica efetivamente pública e as pressões pela mercantilização do mesmo. Os agentes econômicos hegemônicos agem para garantir o controle do espectro, tanto na radiodifusão quanto na redistribuição de faixas do espectro de acordo com novas oportunidades de negócio nas telecomunicações. Conforme Pool (2017, p. 62), no espectro radioelétrico ocorre o mesmo que na questão da terra: não é fácil mover aqueles que "chegaram primeiro" e obtiveram posse ${ }^{49}$. Isso vale para as definições de atribuição ${ }^{50}$ das bandas, mas sobretudo para os concessionários.

49 Na primeira metade do século XX, as concessões eram fornecidas aos primeiros que as solicitavam (ALAFOSSI et al., 2017, p. 91) - o que significava privilegiar os que reuniam as condições econômicas para o acesso às possibilidades de operação técnica.

50 Na gestão do espectro, há três atividades distintas relacionadas a sua divisão: a atribuição (atribución), a destinação (adjudicación) e a distribuição (asignación) de frequências. Segundo Leiva (2012, p. 121), a atribuição refere-se à inscrição de uma faixa de radiofrequências em uma tabela que condicionará seus usos permitidos - podendo ser exclusivos ou compartilhados. A destinação refere-se a inscrição de sistemas ou serviços em um plano de destinação das faixas de radiofrequências, adequado à atribuição. A distribuição, coerente com a destinação, diz respeito à inscrição de uma frequência, faixa ou canal, em uma determinada região, para administração de algum agente. 
Esses conflitos exigem uma compreensão mais apurada sobre os modos e racionalidades que orientam a gestão do espectro. Conforme Leiva (2012, p. 122-123), existem três propostas principais de modelos de gestão do espectro: o predominante ao longo do século XX, de gestão administrativa centralizada do espectro - conhecido como comando-e-controle; e dois alternativos: modelo de outorga de direitos exclusivos e a perspectiva de licenças de uso comum.

O princípio do modelo centralizado é que sem regras técnicoadministrativas que organizem o acesso às frequências, as interferências seriam inevitáveis - motivo pelo qual o acesso deve ser planejado e os usos controlados pelo Estado, que estabelece quais porções do espectro se destinam a quais serviços e com quais tecnologias e outorga essas porções por longos períodos aos agentes que cumpram os requisitos determinados (ALA-FOSSI et al., 2017, p. 221). Nesse caso, as políticas de comunicação que tratam do espectro se dão sobretudo em escala nacional. O reconhecimento do papel do Estado na definição de regras e na determinação de concessões de médio e longo prazo acompanhou uma série de disputas pelo sentido de políticas de comunicação, englobando as políticas que advogam por diversidade e pluralidade.

O avanço da racionalidade neoliberal (DARDOT; LAVAL, 2016) acompanhou um deslocamento do locus do debate sobre políticas de comunicação em nível internacional - o enfraquecimento da agenda da NOMIC, no âmbito da UNESCO ${ }^{51}$, viabilizou um deslocamento da pauta da comunicação para o GATT - que transformou-se em OMC (BECERRA, 2005; MATTELART, 2006) e, posteriormente, para a União Internacional de Telecomunicações - UIT (MORAGAS et al., 2005). A UIT tem como características a orientação de uma discussão pretensamente mais técnica e a participação dos agentes empresariais em sua dinâmica de funcionamento. Nesse contexto, houve uma reorientação do

51 Como já tratado anteriormente, o boicote estadunidense à UNESCO em função das conclusões do Relatório MacBride deram fim ao protagonismo da agenda da NOMIC. Como contam Moragas et al. (2005, p. 10), a partir de 1987 a UNESCO, sob nova direção, estabelece a chamada "Nova Estratégia da Comunicação", realinhada com a visão liberal estadunidense. 
debate global das políticas de comunicação ${ }^{52}$ para o ambíguo projeto da Sociedade da Informação $0^{53}$ (BECERRA, 2005). O protagonismo dos agentes de mercado também deu voz e prioridade às propostas de interesse desses agentes.

Nesse cenário, cresceram modelos liberalizantes para a gestão do espectro, sob a crítica de que o modelo centralizado levaria a uma subutilização do mesmo, em um contexto de crescimento de inovações tecnológicas de comunicação sem fio. O modelo de outorgas de uso exclusivo é uma das propostas - chamada, por Da Silveira (2009, p. 46), de privatização do espectro. Esse modelo pretende mudar a responsabilidade e a lógica de distribuição do espectro do Estado para o mercado. Dessa maneira, "ao invés de um concurso público ou uma distribuição administrativa direta, o que tem lugar para distribuir frequências é um leilão que as outorga ao maior lance" (ALA-FOSSI et al., 2017, p. 147). Além disso, seriam introduzidos, segundo Leiva (2012, p. 123), critérios de economia de mercado na gestão do espectro radioelétrico, não só nos mecanismos primários de distribuição, mas na possibilidade de comercialização do espectro por parte de quem o obteve por qualquer dos mecanismos primários, criando um novo mercado secundário.

Uma perspectiva antagônica a essa é a do espectro tratado como bem comum (BENKLER, 1998). A proposta é não haver direitos de uso exclusivos para nenhum agente, com a ocupação do espectro "ou totalmente livre (open access) ou como bem acessível a um grupo de usuários previamente definidos unicamente a partir de critérios técnicos, que compartilha um uso comum dessa parcela do espectro (spectrum commons)" (LEIVA, 2012, p. 123). Da Silveira (2009, p. 47) defende que esse modelo de espectro aberto, pensado sobretudo para a comunicação de internet sem fio gratuita, permitiria

que todos possam usar as frequências como vias públicas. Caberia ao Estado

52 Análises mais profunda dessa mudança no debate internacional sobre comunicação e os desafios na perspectiva do direito à comunicação foram feitas por McKeena (2012), Pohle (2012) e Mansell (2012).

53 Para Vedel (1996, p. 15), o que garante o sucesso desse tema na agenda pública é justamente sua ambiguidade e sua capacidade de portar múltiplos objetivos. Para mais discussões sobre o projeto de Sociedade da Informação, conferir Becerra (2003). 
definir regras de ordem técnica para assegurar o uso comum das frequências, tais como limites de potência, homologação de equipamentos, orientação para o melhor uso de protocolos de comunicação em determinadas bandas. Tal como em uma avenida, o Estado permite que todos os cidadãos possam por ela transitar desde que respeitando as regras de trânsito.

O elemento compartilhado pelas duas perspectivas é a liberalização ${ }^{54}$ do uso das frequências, com a retirada do Estado dessa gestão (LEIVA, 2012, p. 123) - ainda que ambas tenham perspectivas políticas antagônicas. Há que se considerar, ainda, a ação de emissoras não-concessionadas (ALVES, 2018) na contestação dos modelos vigentes do espectro na radiodifusão - sobretudo como uma resposta à lógica das políticas de comunicação voltadas ao interesse das grandes empresas.

Uma síntese das características desses três modelos principais de gestão do espectro pode ser observada a seguir (Quadro 5). As diferenças entre os modelos são significativas na lógica e no comando da atribuição do espectro, bem como no modelo de exploração.

\section{Quadro 5: Principais características dos modelos de gestão do espectro}

\begin{tabular}{lccc}
\hline Característica & $\begin{array}{c}\text { Gestão administrativa } \\
\text { centralizada / } \\
\text { concessões estatais }\end{array}$ & $\begin{array}{c}\text { Outorga de direitos } \\
\text { exclusivos / } \\
\text { privatização }\end{array}$ & $\begin{array}{c}\text { Licenças de uso comum / } \\
\text { espectro aberto }\end{array}$ \\
\hline $\begin{array}{l}\text { Lógica da atribuição } \\
\begin{array}{l}\text { Controle da } \\
\text { distribuição }\end{array}\end{array}$ & $\begin{array}{c}\text { Mais rígida, estabelecida } \\
\text { pelo Estado }\end{array}$ & $\begin{array}{c}\text { Mais flexível, estabelecida } \\
\text { pelo mercado }\end{array}$ & $\begin{array}{c}\text { Flexível, com regramento } \\
\text { técnico do Estado }\end{array}$ \\
$\begin{array}{l}\text { Forma de distribuição } \\
\begin{array}{l}\text { Uso e exploração do } \\
\text { espectro }\end{array}\end{array}$ & Estado & Mercado & $\begin{array}{c}\text { Nenhum ou por } \\
\text { meio de algoritmos }\end{array}$ \\
\hline
\end{tabular}

Elaboração: André Pasti. Baseado em Leiva (2012).

54 Isso é visível na passagem Belisário e Lara (2016, p. 277, grifo nosso): “Para muitos defensores do 'espectro aberto', o desafio posto é a superação do Estado como ente regulador das concessões para uso da espectro eletromagnético, pois seus critérios e procedimentos para regulação desse recurso são burocráticos $e$ ineficientes. Ao contrário, os rádios inteligentes poderiam se autorregular, encontrando a melhor frequência e modulação para as transmissões, de acordo com a disponibilidade de cada momento". Para os defensores desse modelo, algoritmos poderiam ser utilizados nessa autorregulação. 
Conforme Arroyo (2006, p. 177), ainda que nos dias de hoje cresça o número de agentes e de regiões envolvidos nas dinâmicas da informação e das finanças, "o caráter seletivo se mantém, sobretudo, nas possibilidades de usufruir as novas condições de fluidez e porosidade que o meio técnico-científicoinformacional oferece" ${ }^{\prime 5}$. O acesso ao espectro é estratégico aos agentes que desejam o controle sobre a circulação de informações.

Na América Latina, predomina a centralidade da televisão e do rádio entre os meios de maior alcance nas primeiras décadas do século XXI. Para ilustrar essa situação: em 2009, a pesquisa Latinobarómetro (2009) apontava que 85\% das pessoas na América Latina acompanhava noticiários na televisão sendo que $42 \%$ o fazia diariamente, enquanto mais de $60 \%$ permanecia sem nenhum acesso à internet.

Assim, no processo de definição de propostas em busca da democratização da comunicação no continente e no território argentino no período pós-ditaduras, o acesso plural ao espectro radioelétrico ganhou grande importância. A perspectiva dominante nos movimentos sociais de comunicação esteve baseada em um papel ativo do Estado na regulação do espectro, com as concessões submetidas a controle social, com participação da sociedade na definição de regras da distribuição do espectro, que deveria primar pelos princípios da diversidade e da pluralidade. Essa questão aparece no documento de 2004, já tratado aqui, intitulado "21 Pontos para uma Nova Lei de Radiodifusão para a Democracia", de autoria da Coalizão por uma Radiodifusão Democrática é o quarto dos 21 pontos, citado na epígrafe e abaixo:

As frequências radioelétricas não devem ser transferidas, vendidas nem leiloadas. Ninguém deve apropriar-se das frequências. As frequências radioelétricas pertencem à comunidade, são patrimônio comum da humanidade e estão sujeitas, por sua natureza e princípios, a legislações nacionais, assim como a tratados internacionais. Devem ser administradas pelo Estado, com critérios democráticos e concedidas por períodos de

55 Esse novo meio geográfico, no momento em que a ciência, as técnicas e a informação ganham destaque na construção ou reconstrução do espaço, seria a expressão geográfica da globalização (SANTOS, 2008b).

126 | As redes técnicas no território argentino e as condições infraestruturais para a democratização da comunicação 
tempo determinado àqueles que ofereçam a prestação de um melhor serviço. A renovação das licenças estará sujeita a uma audiência pública vinculativa (COALICIÓN POR UNA RADIODIFUSIÓN DEMOCRÁTICA, 2004, p. 6).

Essa perspectiva, cabe destacar, é baseada em um papel de administração do Estado, com uma concepção de que as concessões não devem ser vistas como mercadorias, mas como um bem público distribuído a partir de uma lógica efetivamente pública.

É fundamental compreender como as transformações normativas e técnicas estão associadas para a organização da comunicação no território. A Lei de Serviços de Comunicação Audiovisual de 2009 incorporou boa parte dos princípios contidos nos 21 Pontos em sua redação, e criou uma série de regramentos para as concessões, como visto no capítulo anterior. A autoridade responsável pela administração do espectro para a radiodifusão também teve mudanças significativas. A AFSCA, autoridade criada com a lei que substituiu o COMFER - herança da norma estabelecida no regime militar - tinha como objetivo criar condições para uma nova distribuição do espectro, a partir dos princípios da lei5 ${ }^{56}$. Mas essa distribuição se articulava, ainda, com tentativas de capilarização de outra infraestrutura para a televisão no território argentino.

A digitalização da televisão se tornou uma oportunidade de transformação da base técnica associada às transformações das políticas de comunicação no marco da LSCA. O processo de digitalização teve início com a escolha da tecnologia para a digitalização televisiva. Ainda que em 1998 a Argentina tivesse anunciado a escolha do padrão estadunidense ATSC (MASTRINI et al., 2016), essa questão só foi retomada após a definição do padrão tecnológico a ser usado na digitalização pelo Brasil, em 2006 - ainda que em um processo controverso ${ }^{57}$. Assim, em 2009, optou-se na Argentina pela adoção da

56 Conforme entrevista já citada de Fernando Torillate, Diretor de Comunicação da AFSCA, ao autor, realizada em março de 2015.

57 No Brasil, as tensões nas escolhas envolviam, conforme Domingues da Silva (2011), os diferentes governos, os radiodifusores organizados (com destaque para a Associação Brasileira de Emissoras de Rádio e Televisão ABERT) e movimentos sociais de comunicação (o Fórum Nacional pela Democratização da Comunicação - 
norma nipo-brasileira. Conforme Sel (2013, p. 141), foi implementado na Argentina “o Sistema Brasileiro de Televisão Digital Terrestre (SBTVD-TB), baseado no sistema japonês denominado ISDB-T [...]. Por iniciativa do Brasil, do Peru e da Argentina, o restante dos países da região (com exceção da Colômbia) adotaram o mesmo padrão de transmissão". Segundo o coordenador do programa de Televisão Digital Aberta (TDA), Osvaldo Nemirovsci ${ }^{58}$, houve a busca de uma unidade regional, inicialmente entre os países do Mercado Comum do Sul (Mercosul), na adoção da tecnologia de televisão digital. Para Krakowiak, Mastrini e Becerra (2014, p. 190), "na América do Sul, predominou um critério geopolítico regional na hora de adotar o padrão tecnológico da TDT [Televisão Digital Terrestre], orientado pelo Brasil". Diferente do Brasil, onde o modelo japonês era defendido pelo Grupo Globo, na Argentina a escolha representava enfrentar interesses de grandes grupos como Clarín - que defendia o modelo estadunidense - e Telefónica - que testava a tecnologia europeia (NEMIROVSCI, 2011, p. 100). Esse consenso regional está ligado às articulações na cúpula da União de Nações Sul-americana (Unasul) de 2009 (MASTRINI et al., 2016, p. 76). Conforme Nemirovsci (2011, p. 106), o tema foi instalado na agenda no então existente Conselho Sul-americano de Educação, Cultura, Ciência, Tecnologia e Inovação (COSECCTI) da Unasul, além de estar presente em reunião da CEPAL.

A digitalização permite a operação de mais canais - de quatro a seis -

FNDC e o Intervozes - Coletivo Brasil de Comunicação Social). Desde os anos 1990, os radiodifusores foram condutores informais do processo de digitalização e pressionaram o governo em defesa de seus interesses com apoio da Anatel, defendiam a adoção da tecnologia japonesa (ISDB-T), enquanto os movimentos sociais defendiam outras tecnologias que permitissem avançar na democratização da comunicação a partir da oportunidade de digitalização. O governo decidiu, em 2006, adotar o modelo japonês (ISDB-T) levemente adaptado. Entre os movimentos sociais, havia críticas sobre a falta de participação da sociedade na decisão encaminhada pelo então Ministro da Comunicação Hélio Costa, muito próximo dos radiodifusores - e pelos limites do modelo tecnológico, "que não permite a entrada imediata de novos atores no universo da radiodifusão [...], garante a manutenção da estrutura concentrada de propriedade e ainda permite às grandes emissoras ocupar um novo nicho transmitindo para receptores móveis (celulares)" (INTERVOZES, 2006b, p. 710). Para o Intervozes (2006a, p. 18-19), a opção pelo ISDB-T refletia "mais do que uma estratégia comercial das emissoras de TV em transmitir em alta definição ou para recepção em movimento. Trata-se, na verdade, da recusa em dividir o espectro eletromagnético".

58 Entrevista de Osvaldo Nemirovcsi para o autor, realizada em 20/09/2016. Nemirovsci foi coordenador geral do Sistema Argentino de Televisão Digital e, antes, quando deputado nacional de Río Negro pela Frente para a Vitória (FpV), presidiu a Comissão de Comunicações e Informática da Câmara de Deputados da Nação Argentina. 
onde antes apenas um transmitia. Ela viabiliza, portanto, novas possibilidades técnicas para uma multiplicação das vozes em circulação. Essas possibilidades podem ou não se concretizar no território, a depender de uma série de condições: a difusão do conjunto sistêmico de objetos técnicos adequados à transmissão e obtenção desses sinais; as condições normativas, sobretudo o regramento sobre o espectro; condições de organização diversas, que abrangem possibilidades de financiamento e capacitação técnica. Esses elementos estiveram e estão em disputa nas diferentes formações socioespaciais latino-americanas.

Importante notar, ainda, que a digitalização cria uma oportunidade de mudança na distribuição do espectro, a partir da desocupação da banda usada para a televisão analógica. Esse chamado "dividendo digital" (ALA-FOSSI et al., 2017; GALPERIN, 2007; LEIVA, 2009a, 2012) torna-se locus de interesses dos agentes hegemônicos na radiodifusão e nas telecomunicações e protagoniza disputas pelo espectro no continente.

Na Argentina, em 2011, a AFSCA apresentou um plano audacioso para conceder 220 licenças para novos canais de televisão - metade para empresas comerciais e metade para organizações sem fins lucrativos -, mas o plano foi postergado algumas vezes e acabou suspenso (BECERRA; MASTRINI, 2017c, p. 34). Ainda assim, uma série de licenças novas foram concedidas para a radiodifusão universitária, para escolas, rádios de povos originários em seus territórios e comunicação comunitária (SEL, 2013, p. 145). Os avanços e contradições desse processo serão analisados no próximo capítulo.

A proposta de redistribuir o espectro, democratizando o acesso a esse recurso, já foi tratada por movimentos sociais de comunicação - especialmente no Brasil - como uma proposta de "reforma agrária do ar" (RED NACIONAL DE MEDIOS ALTERNATIVOS, 2011), relacionando esta agenda à disputa pela terra. Como na questão da terra, não seria possível avançar nesse tema sem uma transformação na estrutura concentrada de poder comunicacional e naqueles que controlam o uso do espectro radioelétrico. Nesse sentido, é possível observar, 
para o caso da LSCA, tanto os avanços normativos do reconhecimento da necessidade de pluralidade e diversidade na ocupação do espectro quanto os entraves que decorrem das dificuldades de aplicação dos limites de licenças em um cenário de judicialização e no curto período de vigência da lei, como visto anteriormente.

Enquanto a LSCA viabilizou um potencial de democratização do espectro pelas novas possibilidades normativas, a Televisão Digital Aberta (TDA) foi uma aposta para efetivação desse possível novo cenário midiático no território, capilarizando uma rede alternativa à controlada pelos grupos empresariais dominantes. 


\subsection{Expansão da rede de televisão digital no território argentino: tentativas de capilarização de uma outra infraestrutura}

[...] menor atenção tem sido atribuída à social e espacialmente desigual acessibilidade à nova base técnica da produção e da vida coletiva, articulada ao processo de consolidação da atual estrutura de comunicações.

Ana Clara Torres Ribeiro, Matéria e espírito (1991).

Como visto anteriormente, a comunicação televisiva na formação socioespacial argentina é marcada pelo predomínio de serviços de televisão paga. Em 2009, estimava-se que 72,92\% dos lares argentinos possuíam televisão por

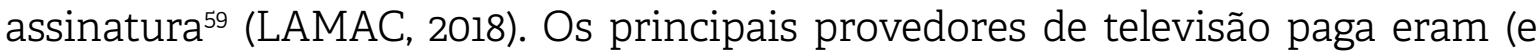
ainda são) Cablevisión - TV a cabo, do grupo Clarín - e DirecTV - via satélite, do grupo estadunidense Liberty Media (MASTRINI et al., 2016, p. 76).

Entre as principais iniciativas que propuseram mudanças nas bases técnicas para o consumo e a produção televisiva figura o projeto da Televisão Digital Aberta (TDA). A TDA foi fundada pelo Decreto n. 1148/2009 e pela Resolução n. 1785/2009. Iniciativa de responsabilidade do Ministério de Planejamento Federal, Investimento Público e Serviços, a TDA foi criada como uma plataforma de televisão com o objetivo de utilizar a tecnologia digital para transmitir gratuitamente imagem e som (ITURRALDE, 2015). O objetivo da rede seria universalizar o acesso à televisão aos que não podiam pagar os serviços privados, ao mesmo tempo que dar espaço a outras práticas na produção televisiva. Para Nemirovsci (2011, p. 78, 2016), a TDA seria uma das formas de expressão material da Lei de Serviços de Comunicação Audiovisual, alinhada com os objetivos de não-concentração, diversidade de vozes, defesa da produção nacional e geração de postos de trabalho vinculados com a radiodifusão em todo o país. Entre os objetivos declarados do sistema de televisão digital, estabelecidos no Decreto n. 1148/2009, constava:

59 Para ilustrar a expressividade desse número, cabe uma relação com a realidade brasileira: em 2009, eram 18,65\% os lares brasileiros com televisão por assinatura. Mesmo em 2018, apenas 42,96\% das residências brasileiras contam com serviço pago de televisão (LAMAC, 2018). 
promover a inclusão social, a diversidade cultural e o idioma do país através do acesso à tecnologia digital, assim como a democratização da informação; facilitar a criação de uma rede universal de educação à distância; estimular a investigação e o desenvolvimento, assim como fomentar a expansão das tecnologias e indústrias da Argentina relacionadas com a informação e a comunicação; planejar a transição da televisão analógica para a digital a fim de garantir a adesão progressiva e gratuita de todos os utilizadores; otimizar o uso do espectro radioelétrico; contribuir para a convergência tecnológica; melhorar a qualidade de áudio, vídeo e serviços; promover a indústria local na produção de instrumentos e serviços digitais; e promover a criação de postos de trabalho e a capacitação dos trabalhadores na indústria tecnológica (ARGENTINA, 2009b, art. $1^{\circ}$, tradução nossa).

O Estado nacional assumiu papel de protagonista no desenvolvimento da televisão digital (MASTRINI et al., 2012). Ela iniciou sua transmissão a partir de abril de 2010 (SEL, 2013, p. 141), com a transmissão do Canal 7 - sinal de televisão pública do Estado nacional. Para a consolidação da televisão digital, foi criado o Sistema Argentino de TV Digital Terrestre - SATVD-T, foi declarada de interesse público a plataforma nacional de TV Digital Terrestre e foi autorizada a prestação dos serviços de uso de infraestrutura, multiplexação e transmissão para TV Digital (SEL, 2013, p. 141). Foi criado, ainda, um Conselho Assessor do Sistema da TDA, dependente do Ministério de Planejamento Federal, Investimento Público e Serviços, integrado por representantes de oito ministérios e com um Fórum Consultivo com participação da sociedade civil (GRZINCICH; ALANIZ, 2017b, p. 8).

Anteriormente, outro conjunto de ações do Estado na infraestrutura ligada à base técnica para circulação de informações esteve ligado à política satelital. Em 2004, havia um risco do país perder as posições orbitais a ela designadas, por falta de investimentos dos concessionários - um consórcio de empresas com o nome fantasia de Nahuelsat, falida desde 2014 (ALIAGA, 2017; RUS, 2016). Assim, através da Lei de n. 26.092/2006, foi criada a Empresa Argentina de Soluções Satelitais, ARSAT. A empresa pública tinha como 
finalidade principal trabalhar com o planejamento, a coordenação e o desenvolvimento de satélites geoestacionários (ARGENTINA, 2006), além de operar serviços correlatos.

Além dos satélites geoestacionários, a ARSAT foi designada para as atividades de expansão da infraestrutura técnica ligada à televisão digital (HURTADO; BIANCHI; LAWLER, 2017; RUS, 2016): tanto as estações de transmissão da televisão digital terrestre, TDT, quanto na modalidade satelital, batizada televisão direta ao lugar, TDH (MASTRINI et al., 2016, p. 77). Conforme Becerra (2015), ainda que a digitalização seja um processo também realizado na televisão paga, o Estado argentino assumiu uma liderança na digitalização da televisão aberta sem paralelo no continente. Na mesma direção, Bizberge, Krakowiak, Labate e Morone (2012, p. 200) afirmam que a implementação da televisão digital na Argentina se destaca na América Latina pelo papel do Estado, que investiu em torres de transmissão, na distribuição gratuita de conversores e no fomento à produção de conteúdos. Foram instaladas 88 estações digitais de transmissão (EDTs) em diferentes pontos do país (Mapa 1). 
Mapa 1: Estações Digitais de Transmissão da Televisão Digital Aberta (TDA) construídas entre 2010 e 2015, por ano de início de operação

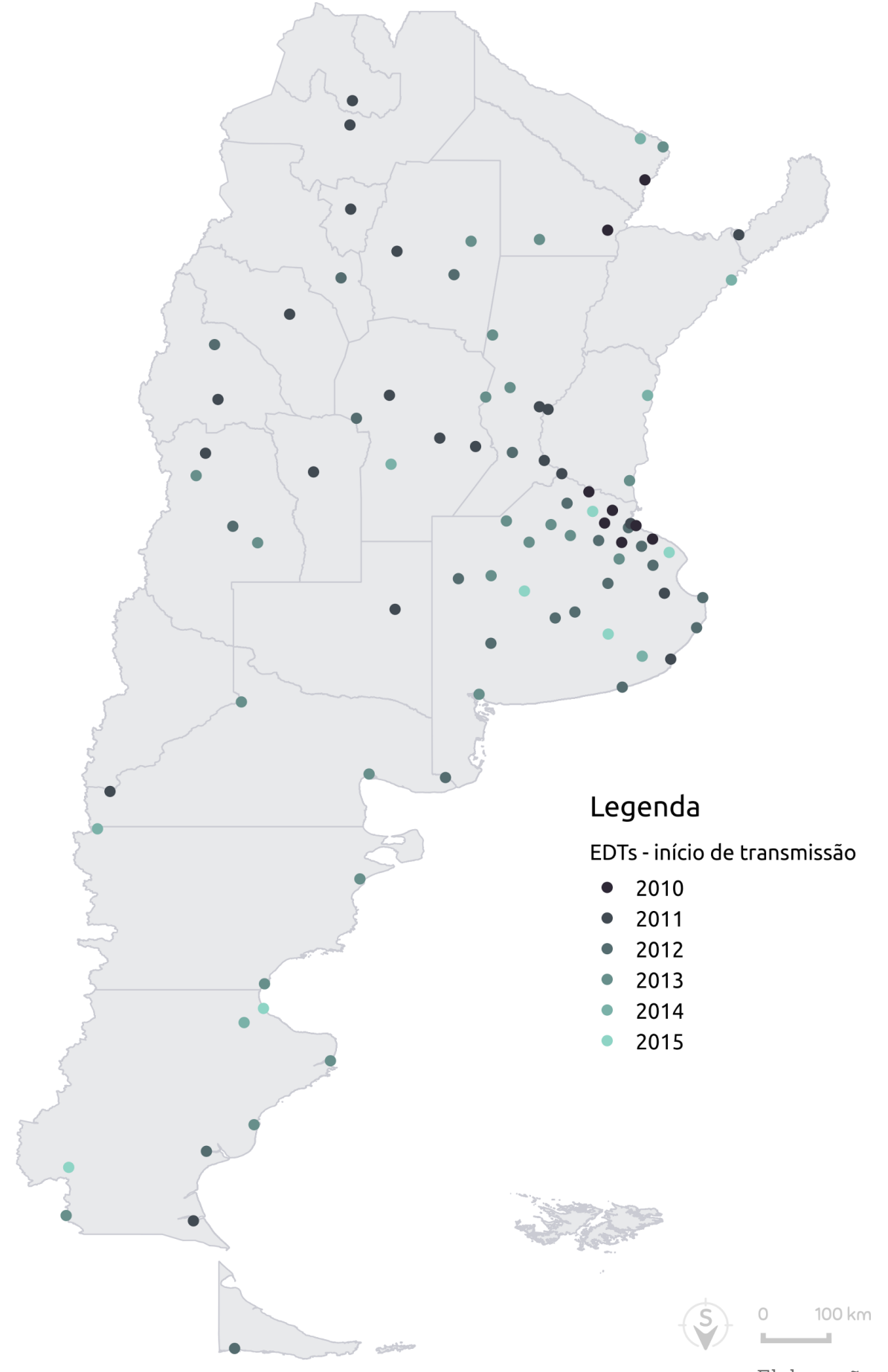

Elaboração: André Pasti. Desenvolvido com os softwares livres QGIS e GIMP. Fonte: ARSAT (2018).

As estações foram instaladas a partir de 2010. Como é possível observar, os anos de maior expansão da rede de infraestrutura foram 2011 e 2012, 
com 22 estações instaladas em cada, e 2013, com 23 novas estações (ARSAT, 2018). A sobreposição da topologia das estações (Mapa 1), com os dados de distribuição da população no território argentino (Mapa 2) permite visualizar a cobertura significativa da rede da TDT nas regiões de maior concentração populacional, como a área metropolitana de Buenos Aires e os departamentos mais populosos.

\section{Mapa 2: Topologia da TDT no território argentino - sobreposição das Estações Digitais de Transmissão com dados populacionais (2015)}

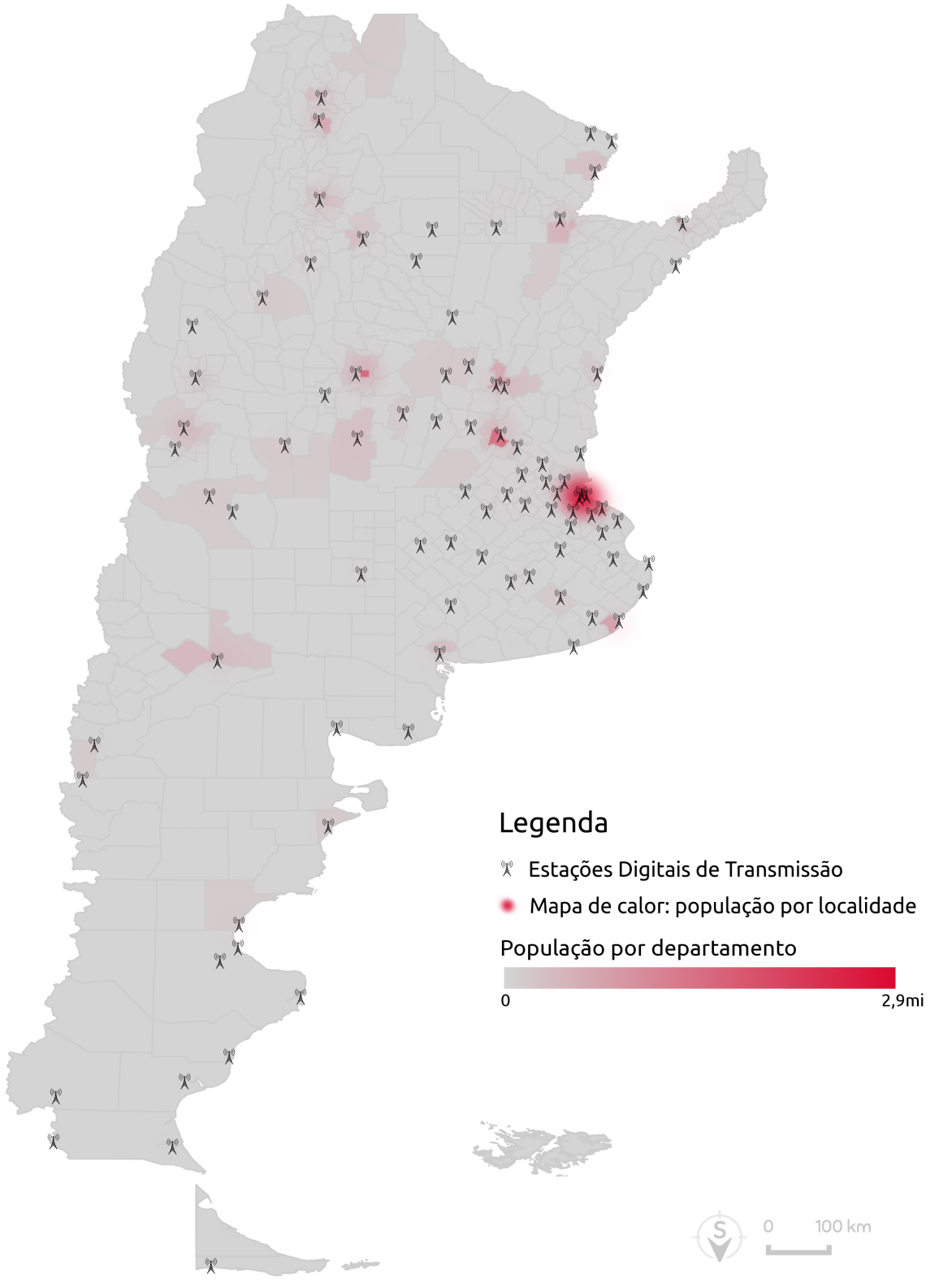

Elaboração: André Pasti Desenvolvido com os softwares livres QGIS e GIMP. Fontes: ARSAT (2018), INDEC (2017). 
Essa distribuição das estações de transmissão permite que a televisão digital atinja uma área de cobertura (Mapa 3) com um alcance potencial de $82 \%$ da população nacional - a meta era de $85 \%$ com as estações, cobrindo as demais áreas com antenas e transmissão via satélite (BECERRA, 2015, p. 180).

Mapa 3: Cobertura da TDT no território argentino - Estações Digitais de Transmissão (2017)

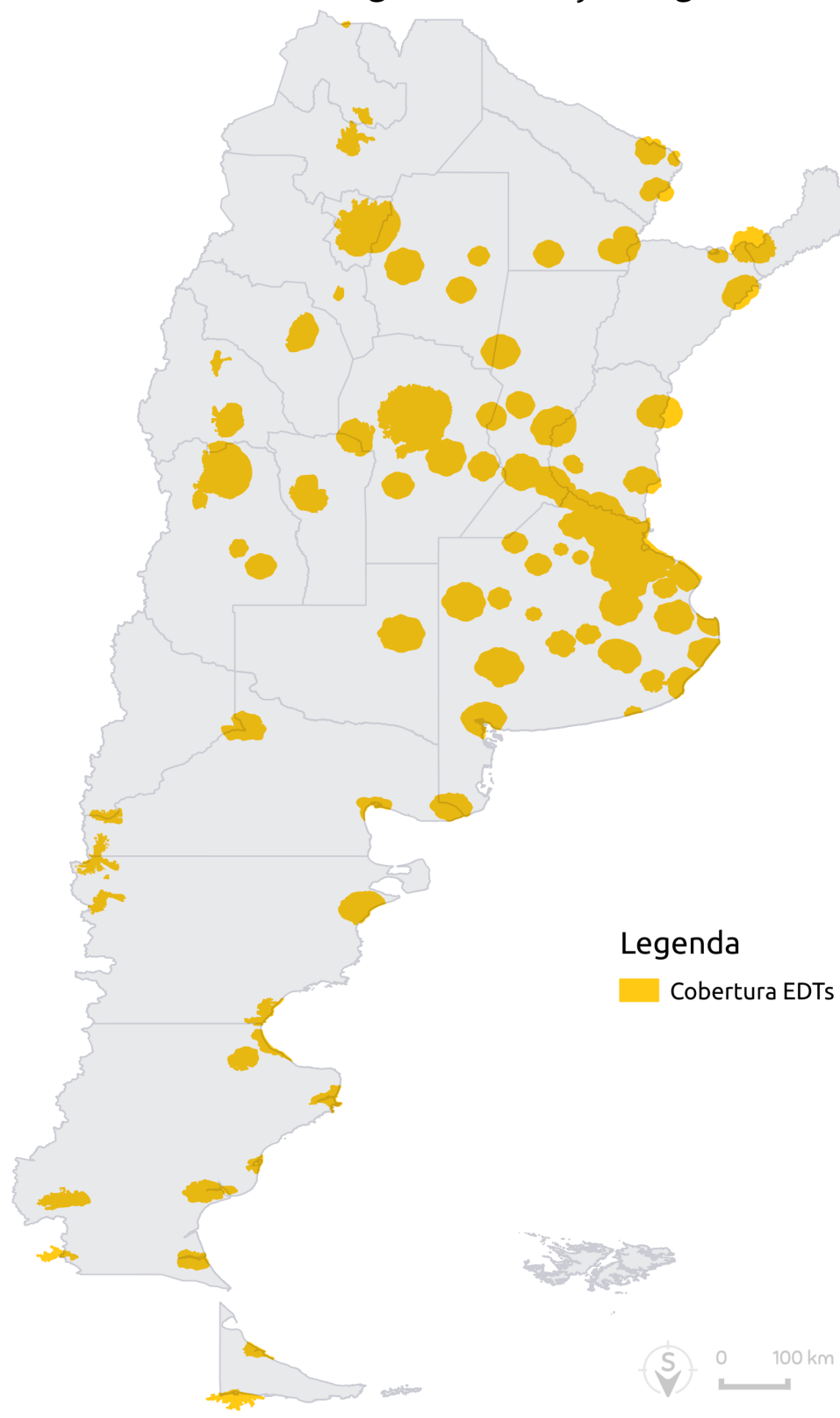

Elaboração: André Pasti Desenvolvido com os softwares livres QGIS e GIMP. Fonte: ARSAT (2018).

Além da infraestrutura terrestre, a ARSAT desenvolveu e lançou em órbita os satélites ARSAT-1, em outubro de 2014, e ARSAT-2, em setembro de 2015. 
Um dos serviços prestados pelo ARSAT-ı é levar o sinal da Televisão Digital Aberta para as localidades não cobertas pelas estações terrestres (GENNARI; LAPUENTE, 2016; SEL, 2013, p. 142), além de internet, dados e telefonia sobre IP. Ainda em 2015, foi aprovada a Lei n. 27.208 (ARGENTINA, 2015c), com um plano de desenvolvimento satelital para o período de 2015 a 20356, propondo o desenvolvimento da indústria satelital, de interesse nacional, como prioridade e política de Estado (HURTADO; BIANCHI; LAWLER, 2017).

Para viabilizar o acesso à televisão digital nos espaços opacos, as políticas de Estado incluíram, ainda, a distribuição gratuita de cerca de um milhão de aparelhos decodificadores de sinal (GRZINCICH; ALANIZ, 2017a), destinados às regiões mais pobres do país, além da instalação de cerca de 5 mil antenas de televisão digital satelital em regiões rurais e mais de 12 mil em escolas rurais e de fronteira (ITURRALDE, 2015). As iniciativas de capilarização dessa infraestrutura no território envolveram, ainda, um programa para financiar a compra de televisores com sintonizador digital (MASTRINI et al., 2016).

Além da viabilização da infraestrutura para a circulação das informações, imagens e sons por meio da televisão digital aberta, houve ações para a criação de canais e de conteúdos. Os primeiros lugares conectados à rede da TDA padeciam de conteúdo, contando apenas com o sinal da televisão pública $^{61}$. Conforme Becerra (2015, p. 180),

como complemento aos investimentos em infraestrutura, o Estado financiou a produção de conteúdos, algo inédito em grande parte do país, e fomentou o equipamento de pequenas e médias produtoras. Os conteúdos dessas produções são abertos, estão disponíveis na internet e podem ser emitidos por canais públicos, privados, cooperativos ou universitários.

60 O plano contempla uma série de aspectos técnicos e econômicos para o desenvolvimento da indústria satelital. Sugere-se conferir o plano na íntegra em Rus (2016) e no anexo da Lei n. $27 . .208$ (ARGENTINA, 2015c).

${ }_{61}$ Em entrevista já citada, Osvaldo Nemirovsci (2016) apontou o problema de chegar ao interior do país com sinal da televisão digital mas sem o conteúdo desejado pela população, o que frustrou o início do programa. A dispersão das políticas de comunicação em distintos ministérios e setores é um dos elementos apontados para explicar essas dificuldades, criando certo distanciamento entre as políticas de conteúdo (cultura e diversidade) e de infraestrutura técnica. A esse respeito, conferir Becerra (2015) e Mastrini e Becerra (2017). 
Para a produção de conteúdos foram três as ações principais, conforme Labate e Carboni (2014, p. 110-111): a criação de um programa territorializado de produção de conteúdos, o programa de Polos Audiovisuais (analisado no próximo capítulo); a realização de concursos de conteúdo televisivo pelo Instituto Nacional de Cinema e Artes Audiovisuais - INCAA; e a transmissão de canais estatais e de alguns grupos midiáticos privados. Esta última aponta para uma contradição com a promessa da democratização do espectro, já que não houve concurso de licenças para esses canais, que operaram de 2010 a 2015 em caráter experimental (BECERRA, 2015, p. 181; LABATE; CARBONI, 2014, p. 110) e foram licenciados sem cumprimento das regras da LSCA, sob o pretexto de ampliar de forma ágil a grade de canais e conteúdos presentes na nova rede. Os canais de cobertura nacional na TDA (Quadro 6) são analisados por González e Caraballo (2014, p. 14-16), Labate (2016, p. 127) e Grzincich e Alaniz (2017a, p. 11).

\section{Quadro 6. Canais nacionais na grade da TDA e seus responsáveis - 2015}

\begin{tabular}{|c|c|c|c|c|c|c|}
\hline Canal & .01 & .02 & .03 & .04 & .05 & .31 (móvel) \\
\hline 22 & $\begin{array}{l}\text { Encuentro } \\
\text { Estado Argentino }\end{array}$ & $\begin{array}{l}\text { Pakapaka } \\
\text { Estado Argentino }\end{array}$ & $\begin{array}{l}\text { TaTeTi } \\
\text { Estado Argentino }\end{array}$ & $\begin{array}{l}\text { Incaa TV } \\
\text { Estado Argentino }\end{array}$ & $\begin{array}{l}\text { TecTV } \\
\text { Estado Argentino }\end{array}$ & $\begin{array}{l}\text { Encuentro } \\
\text { Estado Argentino }\end{array}$ \\
\hline 23 & & $\begin{array}{l}\text { TV Pública } \\
\text { Estado Argentino }\end{array}$ & $\begin{array}{l}\text { Construir TV } \\
\text { Fundación Uocra }\end{array}$ & & & $\begin{array}{l}\text { TV Pública } \\
\text { Estado Argentino }\end{array}$ \\
\hline 24 & $\begin{array}{l}\text { DeporTV } \\
\text { Estado Argentino }\end{array}$ & $\begin{array}{l}\text { Rock\&Pop Se Ve } \\
\text { Grupo Veintitrés }\end{array}$ & $\begin{array}{l}\text { Arpeggio } \\
\text { Albavisión }\end{array}$ & $\begin{array}{l}\text { ViajAR } \\
\text { Estado Argentino }\end{array}$ & & $\begin{array}{l}\text { DeporTV } \\
\text { Estado Argentino }\end{array}$ \\
\hline 25 & $\begin{array}{l}\text { CN23 } \\
\text { Grupo Veintitrés }\end{array}$ & $\begin{array}{l}\text { C5N } \\
\text { Grupo Indalo }\end{array}$ & $\begin{array}{l}\text { Telesur } \\
\text { Multiestatal }\end{array}$ & $\begin{array}{l}360 \mathrm{TV} \\
\text { Electroingeniería }\end{array}$ & $\begin{array}{l}\text { RT } \\
\text { Estado Russo }\end{array}$ & $\begin{array}{l}\text { CN23 } \\
\text { Grupo Veintitrés }\end{array}$ \\
\hline
\end{tabular}

Elaboração: André Pasti. Fonte: TDA (2015b).

Observa-se no Quadro 6 que vários desses canais são de responsabilidade do Estado: a Televisão Pública Argentina (Canal 7); os canais do âmbito do Ministério da Educação - o cultural e educativo Encuentro, o infantil Pakapaka e o esportivo DeporTV; IncaaTV, de cinema nacional e regional; outros criados para a TDA e operados por programadoras privadas, como o infantil TaTeTí e o turístico Viajar; o canal TecTV (Tecnópolis TV), com conteúdo 
informativo de ciência e tecnologia para o público jovem; e a parceria multiestatal latino-americana Telesur, da qual o Estado argentino fazia parte (PASTI, 2013b). O canal informativo russo RT, de propriedade estatal, também está presente na grade de programação. Para além dos canais nacionais, exibidos em todo o território, outros canais de conteúdo próprio, estatais, foram criados, como o ACUA Federal, de conteúdos gerais, e o ACUA Mayor, de conteúdos voltados à população idosa. Ambos trariam conteúdos nacionais e regionais, parte deles produzidos pelos programas de fomento - ACUA é a sigla para "Argentinos cuentan Argentina". Como visto anteriormente, também foram lançados canais privados: Construir TV, da Fundação Uocra, ONG ligada a sindicatos da construção; o musical Rock\&Pop SeVe (antigo Vivra) e o informativo CN23, do Grupo Veintitrés; o musical Arpeggio, da Albavisión; o informativo C5N, do Grupo Indalo; e o 360 TV, de conteúdos gerais, da Electroingeniería SA. O canal Suri TV, da Albavisión, também compôs a grade.

Além desses, as províncias de Misiones, La Pampa, Formosa, Chaco, Santiago del Estero, La Rioja e Jujuy contavam com um canal adicional local em cada província, e as províncias de Buenos Aires, Córdoba, Mendonza e Santa Fe com dois. Na Cidade Autônoma de Buenos Aires, operavam onze canais adicionais, com alcance para parte da área metropolitana - além de ACUA Mayor e ACUA Federal, canais de grupos empresariais como Canal 9, Canal 13, Telefe e América (TDA, 2015b).

Apesar do alcance potencial da nova rede, o consumo efetivo de informações pela TDA não chegou ao patamar das redes de televisão pagas no país. Diferentes estudos entre 2013 e 2014 apontavam para um número entre 5 e $7 \%$ da população, subindo a $20 \%$ de penetração da TDA entre os que não possuíam serviço pago de televisão (BALADRON; RIVERO; ROCA, 2017, p. 5-6; MASTRINI et al., 2014). É um dado relevante, sobretudo considerando os que estavam excluídos das redes de televisão ou só possuíam a oferta de um canal na televisão analógica. Para Sel (2013, p. 142), essa transformação seria histórica, já 
que

a televisão aberta, livre e gratuita esteve historicamente disponível apenas nos grandes centros urbanos, excluindo mais de mil localidades que não superam os dois mil habitantes e de extensas zonas de população rural dispersa. Essa situação afeta $13 \%$ da população que vive ao longo de $65 \%$ do território nacional, para os quais o plano prevê complementar e articular o modo de transmissão terrestre (pelo ar) com o modo satelital direto para as casas.

O alcance efetivo da rede da TDA se articula com questões culturais ligadas ao consumo de informações e aos valores e costumes predominantes e em circulação no território. Essa psicosfera que pode apoiar, acompanhar e anteceder a expansão do meio técnico-científico (RIBEIRO, 201la, p. 268) também compõe o território e é uma dimensão das disputas de sentidos da organização do espaço. Diversos autores (BECERRA, 2015; MASTRINI et al., 2014, 2016) apontam aí um dos limites da TDA como projeto de alternativa à televisão paga comandada pelos conglomerados privados de mídia. Como afirma Becerra (2015, p. 181):

\begin{abstract}
A intenção de criar uma plataforma de acesso gratuito com conteúdos que normalmente não são programados pelos operadores comerciais é afetada pela subestimação dos usos da TV que, longe de ser um artefato, é uma relação social. A penetração da televisão paga, multicanais, é massiva na Argentina. Há décadas, mais de $85 \%$ dos lares a utilizam para sintonizar uma oferta de sinais que não tem concorrência na TDA. [...] A expansão da TDA é dificultada porque os conteúdos mais apreciados pela sociedade não estão disponíveis no interior, onde a TDA está melhor sintonizada e, na AMBA, onde estes canais transmitem, há problemas técnicos de recepção.
\end{abstract}

Há outros elementos além da ausência de alguns dos canais mais conhecidos e consumidos no país na grade da TDA e da dificuldade de mudar as práticas de consumo audiovisual predominantes da televisão paga. Uma pesquisa realizada com usuários da TDA (MASTRINI et al., 2016, p. 87) destaca, ainda, dificuldades quanto à instalação dos equipamentos e a presença de uma desconfiança em relação ao gratuito - tanto do ponto de vista da qualidade ("se é 
bom deve ser pago") quanto em relação ao papel central do Estado na difusão dessa rede - são mencionados, de forma sintética, o medo de manipulação política e a possibilidade de virem a cobrar por seu uso ou acabar com a rede, a depender da mudança de governo. Nesses casos, os ataques dos conglomerados midiáticos privados podem estar entre os elementos da difusão dessas desconfianças.

Entre os conteúdos mais valorizados da TDA, destacam-se o futebol e a programação infantil. Segundo a já mencionada pesquisa com usuários (MASTRINI et al., 2016, p. 86), a transmissão futebolística, articulada com o programa Fútbol Para Todos, implica no acesso livre e de qualidade ao entretenimento popular, associado à sua dimensão de inclusão social. Os conteúdos infantis foram valorizados tanto em variedade quanto em qualidade. Analisando os desafios da TDA, Bergero (2012, p. 13) apontava, além de questões como o financiamento e a efetivação da federalização dos conteúdos, a necessidade de articulação desses meios com a necessidade das pessoas que recebem as transmissões. Para o autor, seria necessário que a população conseguisse se apropriar dessa tecnologia para seus próprios fins - para que as comunidades exijam mudanças, sejam escutadas, se organizem, empreendam ações. Essa questão fez parte da agenda do Programa Polos Audiovisuais Tecnológicos, analisado mais adiante.

É necessário explorar as relações e tensões entre a base técnica para a comunicação e a cultura dos lugares. Pereira (2009, p. 7) considera que

\footnotetext{
O par conceitual tecnosfera-psicosfera poderia ser útil à compreensão da cultura como dimensão híbrida, presente em várias escalas, formada a partir das informações tanto banais quanto estratégicas que circulam pelo território. A cultura seria tributária de tradições que permanecem no território como rugosidades, mas também seria continuamente recriada em novas formas de sociabilidade, novas formas criativas de viver que [...] não se prestam à conversão em mercadoria.
}

As ações, no âmbito do Estado, para a consolidação da TDA apontam 
para esforços de transformação da tecnosfera ligada à difusão do audiovisual no território argentino, marcada pelo predomínio da televisão privada paga. As disputas da infraestrutura acompanham conflitos na psicosfera - os sentidos da comunicação em disputa, nas tensões mercadoria-direito e privado-público, também condicionam as potências e os usos dessa infraestrutura da televisão aberta. A inércia dinâmica das materialidades do território acompanha, ainda, uma inércia das formas de consumo de informações dominantes presentes na psicosfera.

Dentro de tensões e contradições inerentes aos processos políticos, a TDA foi uma aposta desse ciclo de políticas de comunicação de capilarizar outra rede e produzir outras lógicas de consumo, com protagonismo do Estado. Ela esteve articulada com outras ações da base técnica das comunicações, analisadas a seguir. 


\subsection{A internet, o audiovisual ampliado e as ações para o alargamento das bases técnicas na convergência}

[...] as áreas "irracionais" do ponto de vista da modernidade assemelham-se àquilo a que os planejadores chamavam, nos anos 1970, de brechas. [...] Quais as possibilidades do Estado - como federação, como estado federado, como município - na condução dessas irracionalidades, buscando ver nelas uma razão a decodificar, estabelecendo os instrumentos necessários de intervenção e as regras de um planejamento eficaz e aceitável?

Milton Santos. Técnica, Espaço, Tempo (2008b).

A convergência das técnicas do audiovisual, informática e telecomunicações vem transformando profundamente as dinâmicas de produção, circulação e consumo de informações no território. Dias (2007, p. 6) afirma que o encontro entre informática e telecomunicações está no "centro dos debates pluridisciplinares que giram em torno de suas capacidades virtuais de criar condições sociais inéditas, de modificar a ordem econômica mundial e de transformar os territórios". Já em obra de 1983, Pool afirmava que

\footnotetext{
Um processo chamado "convergência de modos" está borrando as fronteiras entre os meios de comunicação, mesmo entre as comunicações ponto a ponto, tais como o correio, o telefone e o telégrafo, e as comunicações de massa, como a imprensa, o rádio e a televisão. Um único meio físico - seja por fios, cabos ou ondas - pode transportar os serviços que no passado eram oferecidos separadamente. Por outro lado, um serviço que no passado era oferecido por um único meio - seja a radiodifusão, a imprensa ou a telefonia agora pode ser oferecido de várias formas físicas diferentes. Assim, a relação um a um que costumava existir entre um meio de comunicação e seu uso está se corroendo. (POOL, 1983, p. 23, tradução nossa).
}

Na mesma direção, Van Cuilenburg e McQuail (2003, p. 197) apontam que a convergência tecnológica significa que os limites entre as tecnologias da informação e as redes de comunicação estão ficando tecnologicamente "borrados" - na convergência entre informática e telecomunicações, para a telemática; na semelhança entre computadores pessoais, televisão e outros dispositivos. Os autores consideram, ainda, que a convergência tecnológica 
acompanha uma convergência econômica no setor de comunicação e mídia, marcada pelas fusões dos ramos ligados à computação, comunicações e telecomunicações e produção e publicação de conteúdo. O mesmo apontava Pool (1983), destacando o processo econômico de propriedade cruzada.

Essas transformações aprofundam características do atual período, da globalização. Para Santos (2000), ele seria caracterizado pela convergência dos momentos, pela presença de um mesmo sistema técnico na escala global, por uma mais-valia globalizada - um motor único, global, do capitalismo - e pela cognoscibilidade planetária - a possibilidade de conhecer exaustivamente e instantaneamente o planeta, graças às técnicas da informação. A expansão da rede de internet e a profusão de objetos técnicos adequados ao recebimento de grande quantidade de informação, incluindo o audiovisual em tempo real, como os tablets e smartphones (BERTOLLO, 2015), têm reorganizado a economia da mídia e os usos do território nesse contexto. Para Triviño (2016, p. 91, tradução nossa),

\begin{abstract}
A introdução de novas formas de comprimir e veicular os sinais produziu a passagem da incipiente distribuição hertziana ou de ar para o cabo; a partir daí, para transmissão por satélite, a digital terrestre e as mais recentes plataformas montadas sobre o protocolo de Internet. [...] o atual panorama televisivo é caracterizado pela coabitação de múltiplas formas de transporte e exploração comercial de conteúdos.
\end{abstract}

A complexidade do circuito de produção audiovisual é impulsionada por essas transformações da convergência, que "tem possibilitado o surgimento e o aperfeiçoamento de plataformas de exibição, que são supridas por obras realizadas especialmente para elas ou mesmo por obras comercializadas em mais de uma janela" (MATTA, 2004, p. 66). Entende-se, aqui, o circuito de produção audiovisual por meio dos arranjos espaciais da chamada "indústria audiovisual" - que engloba quatro mercados: cinematográfico (filmes), radiodifusão (televisão e rádio), vídeo e multimídia (DEBANDE; CHERIT, 2001; LEROY, 2013). Conforme Matta (2004), o circuito engloba agentes que se envolvem 
nas três etapas dos produtos audiovisuais: produção, distribuição e exibição. Por meio das redes e das diversas plataformas disponíveis para exibição dos conteúdos, amplia-se o alcance potencial dos produtos audiovisuais.

Podemos, assim, reconhecer a existência de um setor audiovisual ampliado (MARINO, 2016a, 2017d). Para Marino (2016b, p. 16, tradução nossa), o audiovisual ampliado seria compreendido como aquele

integrado pelos setores de cinema, televisão aberta e paga (analógica e digital) e serviços online. Entende-se, assim, que as novas formas de distribuição desse todo integrado são fruto de um desenvolvimento que não é espontâneo, mas sim que obedece tanto à evolução das tecnologias de informação e comunicação e das indústrias audiovisuais como a fatores externos e estruturais do capitalismo globalizado.

Esse audiovisual ampliado se concretiza no território por meio de um conjunto de objetos técnicos e normas. No marco das políticas de comunicação aqui analisadas, várias ações tratam sobre a base técnica necessária para a convergência. Em primeiro lugar, destaca-se a política de desenvolvimento da indústria de satélites, já tratada, tendo um papel ativo do Estado por meio da empresa pública ARSAT. Além disso, houve ações do Estado voltadas à expansão da rede de fibra óptica e à universalização do acesso à internet e ao desenvolvimento de plataformas de conteúdos audiovisuais online sob demanda.

A internet possui um caráter híbrido, compreendido a partir dos conceitos de conectividade e virtualidade (EVASO, 2007). Conforme Steda (2012, p. 35), "para existir, a rede necessita de infraestruturas e equipamentos que permitam a conectividade e de serviços e informações que circulem por essas infraestruturas - ou seja, de um conteúdo que nelas trafegue, como virtualidade". A autora aponta, ainda, problemas em relação ao acesso físico à internet:

as extensas zonas opacas dos territórios em muitos países continuam sem equipamentos de acesso, pela falta de interesse econômico na expansão desse recurso para essas áreas - mesmo que isto seja um empecilho cada vez 
menor, a partir do desenvolvimento da técnica, que hoje permite o acesso à internet via tecnologias como rádio e satélite [...e] a necessidade de equipamentos de acesso à rede que, apesar de terem seu custo reduzido substancialmente nos últimos anos, ainda se colocam como obstáculo (STEDA, 2012, p. 36).

A agenda da universalização do acesso à internet na Argentina tem um marco ainda na década de 1990, com o Decreto n. 554 (ARGENTINA, 1997), que declara ser de interesse nacional o acesso dos argentinos à internet. Cabe lembrar, com Guido e Versino (2016, p. 227), que na década de 1990, houve uma privatização do sistema de telefonia, que estava até então como responsabilidade da empresa pública Entel. O sistema foi vendido a duas corporações estrangeiras: a espanhola Telefónica e a ítalo-francesa Telecom. Segundo os autores, posteriormente, com a chegada progressiva da internet ao país, o mercado de telecomunicações se concentrou em quatro provedores de serviços de internet: Telefónica, Telecom, Clarín e Telmex (México).

Como afirma Steda (2012) - ao estudar políticas para a banda larga no Brasil - políticas universalizantes do Estado que considerem a totalidade do território nacional podem ser capazes de promover uma verdadeira integração entre os lugares. Apenas durante a década de 2000 é que o Estado argentino recupera progressivamente, um papel mais direto na produção e no provimento de serviços, também na questão das telecomunicações e da internet (GUIDO; VERSINO, 2016, p. 220). Segundo Peirano (2013, p. 64, tradução nossa),

desde 2009, o espaço das políticas públicas tem sido amplamente marcado pela elaboração de diversos planos estratégicos. São identificados tanto planos que buscam orientar o desenvolvimento do setor, como ações ligadas à expansão de infraestruturas e à reconfiguração do setor de telecomunicações.

Apresentado em 2010, o Plano Nacional de Telecomunicações Argentina Conectada foi um plano quinquenal que declarava buscar ampliar a cobertura e melhorar a qualidade do serviço de acesso à internet de banda larga, 
em particular em zonas não rentáveis para agentes privados. $O$ plano apresentava diversos eixos de ação, que abordam temas como inclusão digital, otimização do espectro, produção nacional e geração de empregos em telecomunicações, capacitação, fomento a concorrência e segurança. Um desses eixos é de infraestrutura e conectividade (ARGENTINA, 2010b). O decreto de sua criação declara de interesse público o desenvolvimento, a implementação e a operação da Rede Federal de Fibra Óptica, a cargo da ARSAT, contemplando as obras de infraestrutura necessárias (ARGENTINA, 2010a, art $7^{\circ}$ ). Essas infraestruturas complementariam a base técnica existente e buscariam expandir aos espaços opacos do território argentino o acesso à banda larga - "cobrindo, desse modo, regiões que atualmente não contam com esse tipo de infraestrutura e chegando a zonas que os operadores tradicionais não cobrem" (GUIDO; VERSINO, 2016, p. 221, tradução nossa).

Peirano (2013, p. 77) destaca como um dos aspectos importantes do Argentina Conectada a presença de metas de infraestrutura e conectividade a serem cumpridas até 2015. Para Feider (2015, p. 2), a partir do Argentina Conectada e de outras ações como o protagonismo na TDA, foi estabelecido um desenho institucional da ARSAT como "uma política de comunicação que reconhece a crescente convergência e abarca o domínio de atividades das telecomunicações e dos meios de comunicação". Devido à extensão das responsabilidades da empresa e a seu papel central da execução de grande parte da agenda comunicacional ligada à convergência, o autor defende que devemos considerar a ARSAT em si como uma política de comunicação (FEIDER, 2015, p. $3-7)$.

A Rede Federal de Fibra Óptica (REFEFO), a cargo da ARSAT, previa quatro infraestruturas principais (BALADRON, 2018, p. 79): (1) o Centro Nacional de Operações (NACNOC) e Ponto Nacional de Acesso à Rede (NACNAP), que conectariam a rede internacionalmente, além de terem a previsão de monitorar e operar remotamente equipamentos das redes, assim como gestão e 
armazenamento de dados; (2) Centros Provinciais de Operação (PRONOC) e Pontos Provinciais de Acesso à Rede (PRONAP), com função similar, mas gerindo o tráfego na província - estavam previstos para etapa posterior; (3) a Red Troncal Federal (ou backbone federal), que iria permitir a interconexão entre o NACNAP e os PRONAP; e (4) as redes e anéis provinciais (Red Metro), planejada para habilitar a conexão entre o operador nacional da rede e o operador local, a fim de desenvolver a última milha para oferecer serviços residenciais. A REFEFO era a referência do plano para que fosse possível atingir outros objetivos. Feider, Galanternik e Ingaramo (2013, p. 219) destacam esta entrada do Estado como protagonista na rede de suporte à internet de banda larga no território argentino, cuja atuação poderia alterar a topologia da rede, redistribuindo suas ramificações e modificando as interconexões existentes entre as diferentes redes.

Em uma avaliação breve, é possível apontar avanços e limites do Argentina Conectada ${ }^{62}$. Baladron (2018, p. 170-171) destaca que foi uma experiência disruptiva e nova no contexto das políticas públicas de universalização de internet que o antecederam, no que tange ao foco nos investimentos estatais em infraestrutura para renovar tecnologicamente a rede de cabos de fibra óptica do país. No entanto, a autora aponta que, em dezembro de 2015, as principais dificuldades desse processo eram que, apesar do considerável investimento em infraestrutura da rede, havia uma parte pequena da rede em serviço e operação. Assim, a população ainda não tinha recebido os benefícios que a política apontava: conectividade de alta velocidade nos lugares onde não havia investimentos dos operadores privados por falta de rentabilidade. Em consequência disso, a maioria das metas do plano não foram atingidas, já que estavam baseadas no funcionamento da REFEFO. Ela conclui que

62 Para uma análise mais detida do programa, com uma avaliação de cada um de seus objetivos e metas, recomenda-se a leitura da tese de Baladron (2018). 
tratou-se de um projeto muito ambicioso que, ou não teve um planejamento adequado, ou não foi avaliado e modificado corretamente durante sua implementação. Por outro lado, a falta de articulação com as províncias impediu maiores avanços nas redes dessas jurisdições, aspecto central para oferecer maior capilaridade aos cabos e chegar às regiões geográficas e populações às quais o plano apontava (BALADRON, 2018, p. 170-171).

Além do Argentina Conectada, houve outras iniciativas de universalização do acesso à internet. O programa "Una Computadora Para Cada Alumno", criado por resolução de 2009, foi o primeiro com a temática da introdução de computadores na escola. Em 2010, ele tornou-se a primeira fase do Programa "Conectar Igualdad". Este, do Ministério da Educação, ampliou as entregas de netbooks e fomentou a indústria de produção nacional de computadores - que cresceu, entre 2010 e 2011, 348\% (GUIDO; VERSINO, 2016, p. 230-231). Junto desses programas, foi estabelecido o "Internet para Establecimientos Educativos", que passou a compor o Argentina Conectada.

Ao discutir políticas que buscam intervir na topologia das redes, é necessário considerar as complexas articulações e relações entre as diversas escalas e agentes dos lugares para sua efetivação - lembrando que o território argentino não é homogêneo, nem a rede é uma trama regular (FEIDER; GALANTERNIK; INGARAMO, 2013, p. 219). A disparidade regional na conectividade é evidente, sobretudo entre as áreas metropolitanas e de maior peso econômico em comparação ao restante das regiões, especialmente do norte argentino (MARÍN; CREUS; GARCÍA ZABALLOS, 2013).

A concentração do meio técnico-científico-informacional na formação socioespacial argentina é notória, como pode ser observado nos dados de penetração de internet banda larga. Em 2009, a estimativa era de que, na Cidade Autônoma de Buenos Aires, 46,2\% da população tivesse acesso à banda larga, enquanto a média nacional era de cerca de 9\%, com diversas províncias próximas de nenhum acesso, caso de Jujuy, Formosa e Corrientes (ANESINI, 2009). A quantidade relativa de pessoas conectadas em cada província em 2009 
difere da situação de 2017 (14).

Figura 14: Penetração de banda larga fixa no território argentino - estimativa de percentual de habitantes com acesso por província (2009 e 2017)

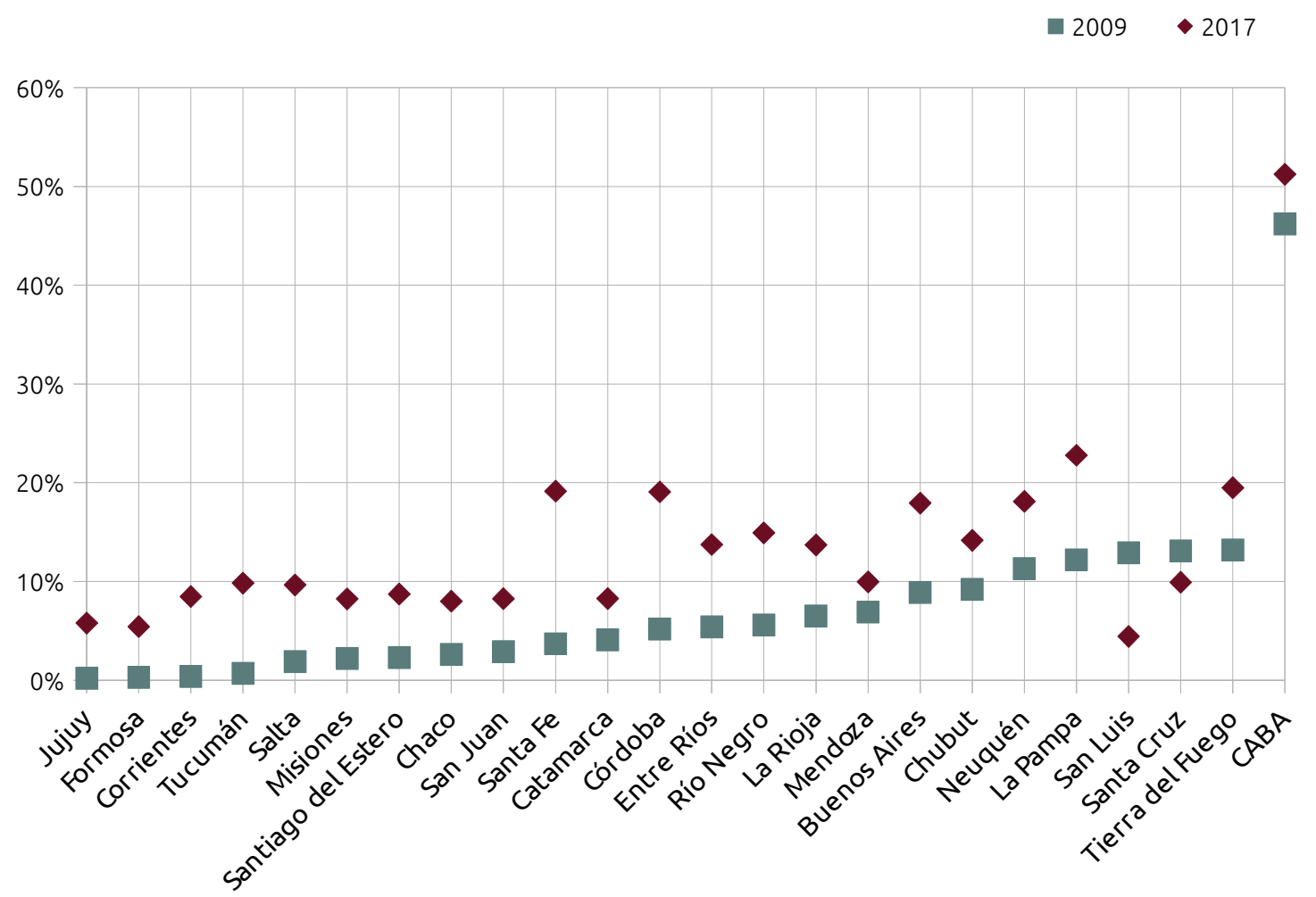

Elaboração: André Pasti. Fontes: (ANESINI, 2009; ENACOM, 2017).

Observa-se que no período entre 2009 e 2017, o acesso à banda larga no país cresceu de uma média de 9\% para cerca de 17\% nacionalmente, com crescimento relativo à população na maioria das províncias. Ainda se mantém uma imensa desigualdade na comparação da Cidade Autônoma de Buenos Aires com as províncias. A inércia das formas materiais herdadas no território e das desigualdades ligadas à base técnica da internet não foi, ainda, transposta.

A internet não é só uma plataforma de distribuição, mas também transforma a comunicação de massa desde a produção à transmissão (CASTELLS, 2015, p. 112). Além da conectividade, também houve ações das políticas de comunicação voltadas à virtualidade, considerando o cenário de audiovisual ampliado. Conforme Triviño (2016, p. 94), a categoria de distribuição 
de conteúdos pela internet ficou conhecida pela expressão em inglês OTT (“overthe-top"), categoria que engloba as aplicações e serviços que utilizam a infraestrutura da internet como plataforma de distribuição de conteúdos - texto, som, imagem e vídeo (TRIVIÑO, 2016, p. 92).

No caso do audiovisual, a expressão OTT foi apropriada e usada pelas empresas de telecomunicações para oferecer seus serviços pagos ("televisão OTT") competindo com outras empresas de televisão paga. O tema das aplicações OTT tem pautado debates internacionais de políticas de comunicação em diversos âmbitos, como na UIT ${ }^{63}$, e até sua definição está em debate. Muitas outras nomeações apareceram, como IPTV (Internet Protocol Television), Televisão web, VOD (Video on demand), Televisão não-linear, Televisão online e outras. As transformações mais significativas dos serviços de televisão por internet em relação ao tradicional são a nova forma de distribuição e a desprogramação de conteúdos - isto é, a desaparição dos horários de emissão e intervalos publicitários (TRIVIÑO, 2016, p. 93). Entre as características das aplicações de serviço audiovisual por internet (Quadro 7) estão os múltiplos dispositivos de recepção, o oferecimento dos vídeos via tecnologia de transmissão (streaming) ou permitindo armazenamento desconectado, além das várias formas de oferecimento dos serviços - há gratuitos, pagos ou com serviços diferenciados entre opções gratuitas e pagas.

${ }^{63}$ Em 2018, a UIT lançou uma consulta pública sobre a regulação de OTTs (POSSEBON, 2018; TELESÍNTESE, 2018). Como já abordado aqui, o deslocamento da agenda sobre comunicação para a UIT teve como característica um deslocamento para uma agenda de maior interesse do meio empresarial, com um enfraquecimento dos temas ligados à pluralidade e diversidade na comunicação. Sobre a regulação democrática de serviços na internet, conferir posicionamento do Observatório Latino-americano de Regulação, Meios e Convergência (OBSERVACOM, 2018). 
Quadro 7: Características das aplicações de serviço audiovisual por internet

\begin{tabular}{ll}
\hline Atributo & Características \\
\hline Infraestrutura de distribuição & Infraestrutura de terceiros (provedores da internet) \\
Licença ou concessão & Desnecessária \\
Dispositivo de recepção & $\begin{array}{l}\text { Múltiplos - televisores, computadores de mesa, computadores portáteis, } \\
\text { consoles de videojogos, tablets e celulares (smartphones) }\end{array}$ \\
Tipo de acesso & Há serviços gratuitos, pagos e de acesso parcial gratuito \\
Tipo de reprodução & Sob demanda ou ao vivo \\
Oferecimento do vídeo & Streaming online. Alguns permitem armazenamento offline \\
Publicidade & $\begin{array}{l}\text { Sem intervalos publicitários tradicionais (ausência de publicidade ou } \\
\text { formatos ainda experimentais) }\end{array}$ \\
\hline
\end{tabular}

Elaboração: André Pasti, baseado em Triviño (2016).

Ainda que a LSCA de 2009 traga um conceito amplo de comunicação audiovisual ${ }^{64}$, ela não trata especificamente desses serviços. A Lei n. 27.078/2014 (ARGENTINA, 2014b), batizada de Argentina Digital, regula serviços de telecomunicações, TIC e recursos associados, em especial os mercados de transporte e distribuição de sinais (CALIFANO, 2017, p. 46). Ela trata do cenário da convergência e oferece uma definição de serviços TIC que incluiria as plataformas OTT, mas deixando-os sujeitos a um marco regulatório específico inexistente (RIVERO, 2016, p. 88). Ainda assim, houve uma série de iniciativas do Estado de plataformas de serviços audiovisual online articuladas com outras ações das políticas de comunicação, como fomento a conteúdo, novos canais, a expansão da televisão digital e outras aqui analisadas. Entre elas, destacam-se: BACUA, CDA, Odeón e ConectaTe.

Em 2011, foram criados o BACUA (Banco Audiovisual de Contenidos Universales Argentino) e o CDA (Contenidos Digitales Abiertos), a partir dos

64 No Art. $4^{\circ}$, a LSCA define comunicação audiovisual como a "actividad cultural cuya responsabilidad editorial corresponde a un prestador de un servicio de comunicación audiovisual, o productor de señales o contenidos cuya finalidad es proporcionar programas o contenidos, sobre la base de un horario de programación, con el objeto de informar, entretener o educar al público en general a través de redes de comunicación electrónicas. Comprende la radiodifusión televisiva, hacia receptores fijos, hacia receptores móviles así, como también servicios de radiodifusión sonora, independientemente del soporte utilizado, o por servicio satelital; con o sin suscripción en cualquiera de los casos". 
diversos planos de fomento a produção de conteúdos, disponibilizando conteúdos audiovisuais gerados nos concursos para acesso e uso (LABATE, 2016, p. 128). Ambos constam do contexto de produção de conteúdos para a televisão digital, administrada pelo Conselho Assessor da TDA, do Ministério de Planejamento Federal, Investimentos Públicos e Serviços ${ }^{65}$. O BACUA surgiu como um repositório e catálogo que reúne todos os conteúdos, e o CDA como uma plataforma de vídeo sob demanda de navegação facilitada para o consumo dos vídeos produzidos. Segundo Sel (2013, p. 144), o repositório seria um ambiente federal de intercâmbio audiovisual, cuja razão de existência seria a busca, organização, digitalização e socialização de conteúdos audiovisuais que reflitam a diversidade cultural argentina.

As produções audiovisuais financiadas pelo Estado para o BACUA foram licenciadas para o próprio Estado, que distribuía os conteúdos nessas plataformas de forma livre e gratuita. O repositório continha séries, documentários, curtas, materiais temáticos e outros. Esse conteúdo alimentava canais novos e já consolidados (LABATE, 2016, p. 129). Triviño (2016, p. 108) aponta como canais que utilizavam conteúdos do BACUA: TV Pública - Canal 7, Encuentro, Construir, Canal 10 de Río Negro, Canal 11 de Formosa, Canal 11 de Ushuaia, Canal 13 de Tierra del Fuego, Canal 3 de La Pampa, Canal 9 de Río Gallegos, Canal 9 de La Rioja, Canal 12 de Trenque Lauquen, Canal 10 de Córdoba, Canal 10 de Tucumán, Canal 12 de Misiones e o canal cooperativo Colsecor.

Conforme Rivero (2016, p. 92), o Ministério firmou acordos com os fabricantes LG, Sony, Philips e Samsung para incorporar o CDA em alguns dos modelos de aparelhos de televisão (Smart TV), além de ter desenvolvido aplicativos para dispositivos móveis nas plataformas Android e iOS. Segundo Rivero (2016, p. 93-94), outros planos anunciados que não vieram a ser efetivados até 2015 foram: compatibilizar o CDA com decodificadores distribuídos da rede da TDA; integrar conteúdo com plataformas de vídeo sob demanda privadas,

65 Este ministério foi criado em 2003, pelo governo de Néstor Kirchner, e extinto em 2015, pelo governo Mauricio Macri. 
como OnVideo (Telefónica) e Arnet Play (Telecom); e criar uma rede latinoamericana para o intercâmbio de conteúdos sob demanda com outros países da região. Em janeiro de 2015, o CDA anunciou ter ultrapassado 6 milhões de vídeos assistidos (MARIE, 2015). A imagem das telas do BACUA e do CDA (15) ilustram a diferença do serviço de catálogo da plataforma de consumo de vídeos sob demanda.

\section{Figura 15: Tela inicial do BACUA e do CDA (versão para acesso por computador)}

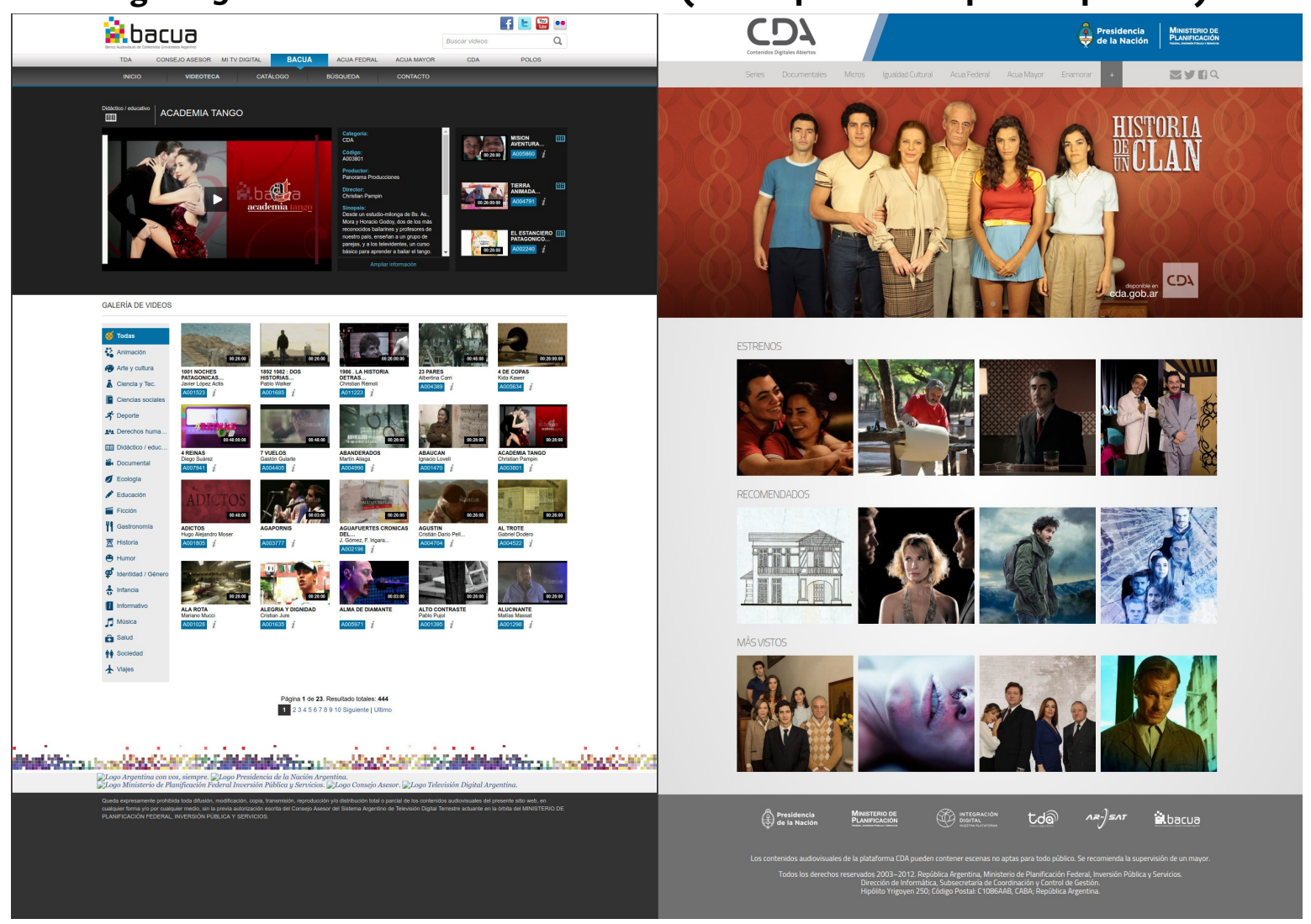

Montagem elaborada pelo autor. Telas de 2015 capturadas do Internet Archive (2018).

Um dos desafios do BACUA, do CDA e das produções audiovisuais realizadas sob financiamento estatal estava relacionado aos direitos sobre as obras audiovisuais. Como financiador, o Estado nacional centralizou os direitos sobre essas obras. Essa escolha poderia dificultar a circulação das produções em caso de uma mudança de governo, como apontado por Piwowarsky (2016).

Em 2012, a educ.AR, empresa pública do Ministério da Educação responsável pelos canais Encuentro, Pakapaka e pelo DeporTV, apresentou a 
plataforma de vídeo sob demanda Conectate (16). A plataforma disponibilizava os conteúdos desses canais sob demanda. Como será visto no próximo capítulo, muitas das produções desses canais, sobretudo Pakapaka e Encuentro, eram concebidas como conteúdos educativos, com usos potenciais por alunos e professores. A plataforma permitia assistir aos canais ao vivo, navegar pelos conteúdos - categorizados por canal - e assistir online, pela tecnologia streaming, assim como descarregar os conteúdos e armazená-los.

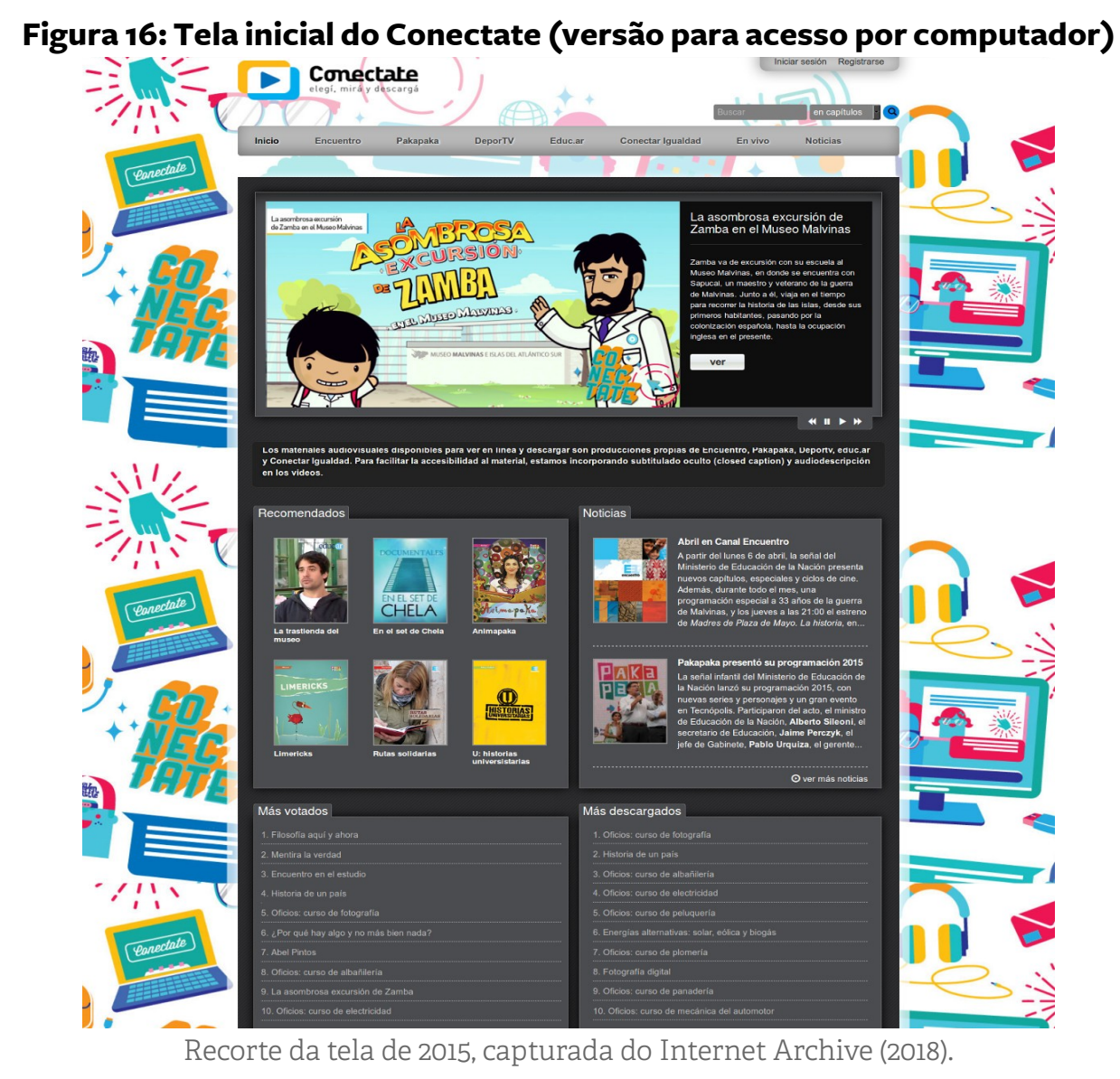

No início de 2015, a empresa estatal ARSAT e o Instituto Nacional de Cinema e Artes Audiovisuais (INCAA) firmaram um convênio para lançar uma plataforma mais completa de vídeo sob demanda, com conteúdo nacional, regional e internacional (RIVERO, 2016, p. 94). A plataforma foi lançada chamada Odeón e divulgada como um "Netflix argentino", como referência à plataforma privada que era a líder global nesse serviço. Conforme Gutiérrez (2016, p. 484), 
esta plataforma compilava material do BACUA, do CDA, do Conectate, do Fútbol para Todos, outros conteúdos da TDA, da Radio y Televisión Argentina (RTA), do Centro de Producción e Investigación Audiovisual (CePIA) e da Escuela Nacional de Experimentación y Realización Cinematográfica (ENERC). Ela possuía conteúdos nas seguintes categorias: Animação, Aventura, Comédia, Comédia Dramática, Drama, Documentários, Esportes, História, Infantil, Musical, Policial e Terror. Segundo Rivero (2016, p. 94), o Odeón foi o primeiro dos projetos de vídeo sob demanda a propor um modelo de distribuição integrador, onde confluem conteúdos originais das demais plataformas estatais que, até então, funcionavam como projetos independentes com poucos pontos de contato.

Ao observar características das quatro aplicações (Quadro 8), se verifica um projeto comum de disponibilizar conteúdos audiovisuais de maneira gratuita para garantir visibilidade a produtos das políticas de fomento.

\section{Quadro 8: Características das aplicações de serviço audiovisual público por internet na Argentina (2015)}

\begin{tabular}{|c|c|c|c|c|}
\hline & BACUA & CDA & ConectaTe & Odeón \\
\hline Início de operação & 2011 & 2011 & 2012 & 2015 \\
\hline Tipo de serviço & $\begin{array}{l}\text { Repositório de } \\
\text { conteúdos } \\
\text { audiovisuais }\end{array}$ & $\begin{array}{l}\text { Agregador de vídeo } \\
\text { sob demanda }\end{array}$ & $\begin{array}{l}\text { Agregador de vídeo } \\
\text { sob demanda }\end{array}$ & $\begin{array}{l}\text { Agregador de vídeo } \\
\text { sob demanda }\end{array}$ \\
\hline URL & bacua.gob.ar & cda.gob.ar & conectate.gob.ar & odeon.com.ar \\
\hline Propriedade & Estatal & Estatal & Estatal & Estatal \\
\hline Órgão responsável & $\begin{array}{l}\text { Conselho TDA - } \\
\text { Min. Planejamento }\end{array}$ & $\begin{array}{l}\text { Conselho TDA - } \\
\text { Min. Planejamento }\end{array}$ & $\begin{array}{l}\text { educ.AR - } \\
\text { Min. Educação }\end{array}$ & INCAA e ARSAT \\
\hline Fontes de conteúdo & $\begin{array}{l}\text { Produções } \\
\text { financiadas pelos } \\
\text { programas de } \\
\text { fomento da TDA }\end{array}$ & $\begin{array}{l}\text { Produções } \\
\text { financiadas pelos } \\
\text { programas de } \\
\text { fomento da TDA }\end{array}$ & $\begin{array}{l}\text { Produções dos } \\
\text { canais Encuentro, } \\
\text { Pakapaka e } \\
\text { DeporTV }\end{array}$ & $\begin{array}{l}\text { INCAA, CDA, } \\
\text { BACUA, ConectaTe, } \\
\text { RTA, CePIA, Fútbol } \\
\text { para Todos, ENERC }\end{array}$ \\
\hline Forma de acesso & Gratuito & Gratuito & Gratuito & Gratuito \\
\hline
\end{tabular}

Elaboração própria, com base em Triviño (2016), Rivero (2016) e Labate (2016).

Destaca-se, assim, uma mudança significativa no que tange ao papel 
do Estado em todo o circuito audiovisual - desde a formulação de ações relacionadas às infraestruturas que viabilizam a circulação dos conteúdos no cenário do audiovisual ampliado, ao fomento da produção e à criação de plataformas de distribuição. Essas ações do Estado se dão em um conjunto de ações por vezes fragmentadas, por vezes integradas - e repleto de contradições.

A provocação de Milton Santos na epígrafe deste capítulo aponta para um desafio levantado pelo autor: buscar formas de planejamento, a partir do Estado, para além de fórmulas pré-fabricadas. No movimento contraditório da história, há que se explorar possibilidades de ação, também dentro do Estado, capazes de potencializar as condições dos lugares para que as vozes se ampliem, que as informações a partir das distintas realidades se façam presentes em circulação no território.

Ao analisar as ações para a base técnica, percebe-se, nesse curto período de tempo de vigência da LSCA de 2009 e das políticas de comunicação alinhadas com o sentido proposto por esse marco normativo, um protagonismo do Estado na comunicação, com ações em distintos espaços de governo e outros órgãos do Estado. Conforme Labate (2016, p. 131), surgiu um extenso laboratório de ideias e grandes investimentos no campo audiovisual, mas ainda faltam políticas mais integrais que articulem os distintos setores do Estado envolvidos nesse processo.

Nesse processo contraditório, é possível notar que as ações propostas no marco dessas políticas dialogam com os três objetivos apontados por Ana Clara Torres Ribeiro para a universalização do acesso às bases técnicas, já mencionadas - a ampliação do acesso social às técnicas, a promoção de outros usos e o estabelecimento de normas que busquem garantir o controle social dessas bases técnicas (RIBEIRO, 2000, p. 22). Esse processo acompanhou ações buscando romper com o forte centralismo geográfico e econômico na produção de conteúdos (LABATE, 2016, p. 131). Algumas destas serão analisadas no próximo capítulo. 
158 | As redes técnicas no território argentino e as condições infraestruturais para a democratização da comunicação 


\section{capítulo 4}

\section{Promoção da comunicação ascendente}

no território argentino 


\section{Promoção da comunicação ascendente no território argentino}

As condições atuais permitem igualmente antever uma reconversão da mídia sob a pressão das situações locais (produção, consumo, cultura). A mídia trabalha com o que ela própria transforma em objeto de mercado, isto é, as pessoas. Como em nenhum lugar as comunidades são formadas por pessoas homogêneas, a mídia deve levar isso em conta. Nesse caso, deixará de representar o senso comum imposto pelo pensamento único. Desde que os processos econômicos, sociais e políticos produzidos de baixo para cima possam desenvolverse eficazmente, uma informação veraz poderá dar-se dentro da maioria da população e ao serviço de uma comunicação imaginosa e emocionada, atribuindo-se, assim, um papel diametralmente oposto ao que lhe é hoje conferido no sistema da mídia.

Milton Santos, Por uma outra globalização (2000).

Como visto, os círculos de informações ascendentes se referem aos dinamismos ligados ao lugar, ao cotidiano compartilhado e pressupõem a troca. É importante notar que a mudança da dinâmica da circulação de informações dominada por círculos descendentes - em busca de uma ampliação da comunicação ascendente - depende de novas condições materiais, normativas, novos sentidos em circulação na psicosfera e outras possibilidades de financiamento.

São analisadas, aqui, dinâmicas relacionadas às políticas de comunicação no território argentino que propõem avanços nessa direção, sob diferentes aspectos. Com maior ênfase, são investigadas as políticas de regionalização da produção audiovisual, na iniciativa do programa Polos Audiovisuais Tecnológicos. Em seguida, são analisadas ações ligadas à comunicação comunitária, especialmente o financiamento dos meios ligados à produção da informação ascendente por meio do FOMECA (Fundo de Fomento para Meios de Comunicação Audiovisual). Por fim, são discutidas ações do âmbito da televisão pública, com ênfase na experiência e nas concepções do canal Pakapaka em relação à dinamização da representação e da voz do lugares. 


\subsection{O programa Polos Audiovisuais e a regionalização da produção audiovisual}

La capacidad nacional se debe diferenciar del enorme poder de emisión concentrado en una o pocas empresas o en uno o pocos lugares del territorio de cada país; así, el grado de concentración y descentralización de la comunicación se convierte también en un indicador importante de su desarrollo. Los monopolios privados y el centralismo excesivo constituyen amenazas similares al control estatal en materia de desarrollo de la capacidad de comunicar.

Diego Portales, Comunicación limitación o identidad? Respuestas a la crisis (1984).

Después de tanto tiempo de haber sido negadas, excluidas de la televisión mal llamada "nacional" las gentes de las regiones quieran verse, mirarse en sus colores y sus paisajes, en sus personajes y sus fiestas.

Jesús Martín-Barbero, La comunicación plural. Paradojas y desafíos (1995).

A concentração da riqueza e a centralização do comando da economia e do território argentino na capital Buenos Aires é bastante expressiva, configurando uma macrocefalia (VAPNARSKY, 1995). Na comunicação, as regiões do interior do país também permanecem em um papel subordinado, como receptores de informações da metrópole de Buenos Aires - que, nas redes informacionais globais, é um nó subordinado aos centros de comando dos conglomerados e agências transnacionais de informação. É importante notar que, "se a produção dos meios de comunicação se encontra centralizada, os imaginários sociais que se consolidam, legitimam e difundem respondem à perspectiva existente na Capital Federal, deixando de lado a diversidade regional presente no país" (ITURRALDE, 2015, p. 173). Assim, ações para regionalizar a produção de informações, sobretudo o audiovisual, ganham centralidade e urgência.

Para Iturralde (2015), a democratização da comunicação só será possível se o público em todo o território argentino puder ter contato estreito com os sistemas de comunicação, se a totalidade dos habitantes puder participar 
da produção, da adoção de decisões e do planejamento da comunicação e se o povo possuir a capacidade de expressar sua identidade frente à diversidade dentro da comunidade nacional e à presença transnacional. Todavia, esse é um processo que encontra resistências no curto prazo - já que as condições materiais e normativas, os sistemas de objetos e ações dispostos no território, herdados nesse período, exercem uma inércia dinâmica para sua transformação (SANTOS, 2006). O conjunto de ações voltadas à descentralização da produção de informações requer, entre outras coisas, pessoal formado em saberes específicos, equipamentos, construção de redes com diversas instituições e, sobretudo, o compromisso com setores que historicamente permaneceram à margem das instâncias de participação em meios de comunicação (ITURRALDE, 2015, p. 173).

Na atualidade, segundo Valverde (2015, p. 392), “os Estados já aceitaram que é preciso pensar na cultura como via importante para o desenvolvimento regional". A partir do reconhecimento do direito à comunicação e da necessidade de iniciar um processo que transforme esse centralismo exacerbado na Argentina, surgiram algumas iniciativas no novo marco normativo da Lei de Serviços de Comunicação Audiovisual (n. 26.522/2009). A principal política para a regionalização da produção de conteúdos audiovisuais foi no sentido da implementação de seu artigo 153, que prevê:

\footnotetext{
Habilita-se o Poder Executivo nacional a implementar políticas públicas estratégicas para a promoção e defesa da indústria audiovisual nacional [...] Para este fim, deverá adotar medidas destinadas a promover a formação e o desenvolvimento de polos de produção de conteúdos audiovisuais nacionais para todos os formatos e meios, facilitando o diálogo, a cooperação e a organização empresarial entre os atores econômicos e as instituições públicas, privadas e acadêmicas, em benefício da competitividade. (ARGENTINA, 2009C).
}

Apesar da presença da expressão competitividade como fim - que é um imperativo do período da globalização (SANTOS, 2000, p. 46), na razão neoliberal (DARDOT; LAVAL, 2016) - o artigo 153 da LSCA vem carregado de outro 
sentido para a promoção do audiovisual regional - ele expressa, mais adiante, a necessidade de ações para a criação de valor "não apenas em seu aspecto industrial, mas como mecanismo da promoção de diversidade cultural e de suas expressões" (ARGENTINA, 2009c). As ações previstas neste artigo englobam, entre outras medidas: capacitação dos setores envolvidos na produção audiovisual, considerando os aspectos acima mencionados; promoção da federalização da produção, estimulando conteúdos locais das diferentes províncias e regiões do país; desenvolvimento do setor audiovisual de modo que este possa ter sustentabilidade econômica; desenvolvimento de estratégias e coproduções internacionais que permitam produzir mais radiodifusão de caráter educativo, cultural e infantil; e implementação de medidas para a inserção de produções audiovisuais locais no exterior (ARGENTINA, 2009c). Para efetivar a política prevista na LSCA em alinhamento com essa concepção, foi criado o programa Polos Audiovisuais Tecnológicos (PAT).

\subsubsection{Polos e Nós Audiovisuais: do desenho institucional à efetivação no território}

O programa Polos Audiovisuais Tecnológicos tinha o objetivo formal de contribuir para a existência de uma televisão federalizada, inclusiva, de entretenimento de qualidade, que transmita conhecimento, em busca da diversidade da produção de pluralidade de vozes (ARGENTINA, 2012, p. 14). O programa buscava instalar e fortalecer as capacidades para a produção nacional de conteúdos para a TV digital, com vistas à promoção da igualdade de oportunidades e a diminuição das assimetrias entre províncias e regiões (SEL, 2013, p. 142).

O PAT foi criado e dirigido pelo Conselho Assessor do Sistema Argentino de Televisão Digital Aberta (TDA), do Ministério de Planejamento Federal, Investimentos Públicos e Serviços. Junto do Conselho, foi realizada uma cooperação entre o Estado e as universidades públicas nacionais ${ }^{66}$, nucleadas no

66 Em entrevista já citada neste trabalho, Rinesi (2016) conta que houve, nesse período, uma série de convênios 
Conselho Interuniversitário Nacional - CIN (PAT, 2015). Conforme Carboni e Labate (2012, p. 3), a parceria se iniciou em julho de 2010, quando surgiu um vínculo estável entre o Ministério - por meio do Conselho da TDA - e o CIN, por meio da Rede Nacional Audiovisual Universitária (RENAU). O programa era coordenado a partir do Conselho da TDA, responsável pelos aspectos técnicos e organizativos, enquanto o CIN fazia a gestão dos recursos financeiros.

O projeto se baseou em um processo de regionalização do território argentino. Benedetti e Salizzi (2016) resgatam diversas regionalizações do país realizadas por geógrafos e por estudiosos das ciências naturais. Segundo os autores, cada região que conhecemos no presente teve sua origem em um momento determinado e, em sua conformação, houve situações que remetem a diálogos interdisciplinares, agendas das instituições interessadas nessas regionalizações e disputas entre grupos da comunidade de especialistas (BENEDETTI; SALIZZI, 2016, p. 29). Essas regionalizações foram consolidando o reconhecimento de algumas regiões (Quadro 9).

\section{Quadro 9: Divisões regionais acrescentadas pelos principais estudos de regionalizações na Argentina, de 1839 a 1988}

\begin{tabular}{|c|c|c|c|c|}
\hline & 1839 - 1876 & 1908 - 1930 & 1946 - 1958 & $1964-1988$ \\
\hline $\begin{array}{l}\text { Autores de } \\
\text { destaque }\end{array}$ & $\begin{array}{c}\text { Parish (1839), Martin } \\
\text { de Moussy (1864), } \\
\text { Burmeister (1876) }\end{array}$ & $\begin{array}{c}\text { Delachaux (1908), } \\
\text { Denis (1920), Kühn } \\
\text { (1930) }\end{array}$ & $\begin{array}{c}\text { Daus (1957), } \\
\text { Frenguelli (1946), } \\
\text { Difrieri (1958) }\end{array}$ & $\begin{array}{l}\text { Zamorano (1964), } \\
\text { Chiozza (1974; 1977), } \\
\text { Roccatagliata (1988) }\end{array}$ \\
\hline $\begin{array}{l}\text { Divisões } \\
\text { regionais } \\
\text { acrescentadas }\end{array}$ & $\begin{array}{c}\text { Pampa, Litoral, } \\
\text { Região central, } \\
\text { Mesopotamia, Cuyo, } \\
\text { Andes e Patagonia } \\
\text { (esboço). }\end{array}$ & $\begin{array}{l}\text { Patagonia, Chaco, } \\
\text { Puna, Pampa } \\
\text { ocidental (seca), } \\
\text { Serras pampeanas, } \\
\text { Cordilheira. }\end{array}$ & $\begin{array}{l}\text { Noroeste (NOA), } \\
\text { Estepa, Ilhas. }\end{array}$ & $\begin{array}{l}\text { Nordeste (NEA), } \\
\text { reg. metropolitana, } \\
\text { Antártica e/ou } \\
\text { região marítima } \\
\text { antártica. }\end{array}$ \\
\hline
\end{tabular}

Elaboração: André Pasti, com base em Benedetti e Salizzi (2016).

Esse processo é importante porque marca os imaginários das regionalizações, que são referenciados nas políticas públicas. Conforme Quintero (2002), esse imaginário é bastante marcado pelas chamadas "regiões geográficas" argentinas, difundidas nos processos de escolarização no século XX

entre o Estado e as Universidades para efetivar diferentes políticas. 
- dividindo o território entre planície dos Pampas, planície Chaqueña, Mesopotâmia, serras Pampeanas, Cuyo, Noroeste, planalto Patagônico e Andes Patagônicos. Outra regionalização utilizada pelo Estado para o planejamento do território é baseada em acordos entre as províncias, regionalizando o território entre: Nordeste (NEA); Noroeste (NOA); Novo Cuyo; Centro e Buenos Aires; e Patagônia (ARGENTINA, 2011).

As políticas culturais utilizavam outras formas de regionalização. No caso do cinema, a divisão regional oficial do INCAA é baseada em: NEA, NOA, Centro, Cuyo e Patagônia (INCAA, 2018). Para políticas como o Atlas Cultural, o território foi regionalizado em NEA, NOA, Centro, Cuyo, Patagônia e Buenos Aires (ARGENTINA, 2014a). Para a efetivação dos objetivos dos PAT, foi realizada uma outra regionalização do território argentino, em nove Polos - escolhidos por critérios de "proximidade entre as províncias, potencialidades produtivas e/ou afinidade sociocultural" (PAT, 2015). Conforme a coordenadora do programa, Eva Piwowarski ${ }^{67}$, a regionalização buscava representar melhor a complexidade regional do país em comparação à utilizada em outras políticas culturais do país.

As regiões definidas pelo Programa Polos Audiovisuais foram: NEA (nordeste argentino), NOA (noroeste argentino), Centro, Centro Este (centro-leste, também chamado de Polo Litoral), Cuyo, Metropolitano (referente à AMBA), Província de Buenos Aires, Patagônia Sul e Patagônia Norte (Mapa 4). Para cada um desses Polos (regiões) foram designadas Universidades Nacionais Coordenadoras do programa. Essas Universidades foram responsáveis por articular, com outras instituições universitárias e com o setor audiovisual local, uma rede federal de produção audiovisual.

67 Entrevista de Eva Piwowarski ao autor, em setembro de 2016 em Buenos Aires. Piwowarski é produtora, diretora, atriz e gestora cultural. Ela foi integrante do Conselho Assessor da TDA e coordenou o Programa Polos Audiovisuais Tecnológicos, além do Programa Mercosul Audiovisual. 


\section{Mapa 4: Polos Audiovisuais e Universidades Coordenadoras}

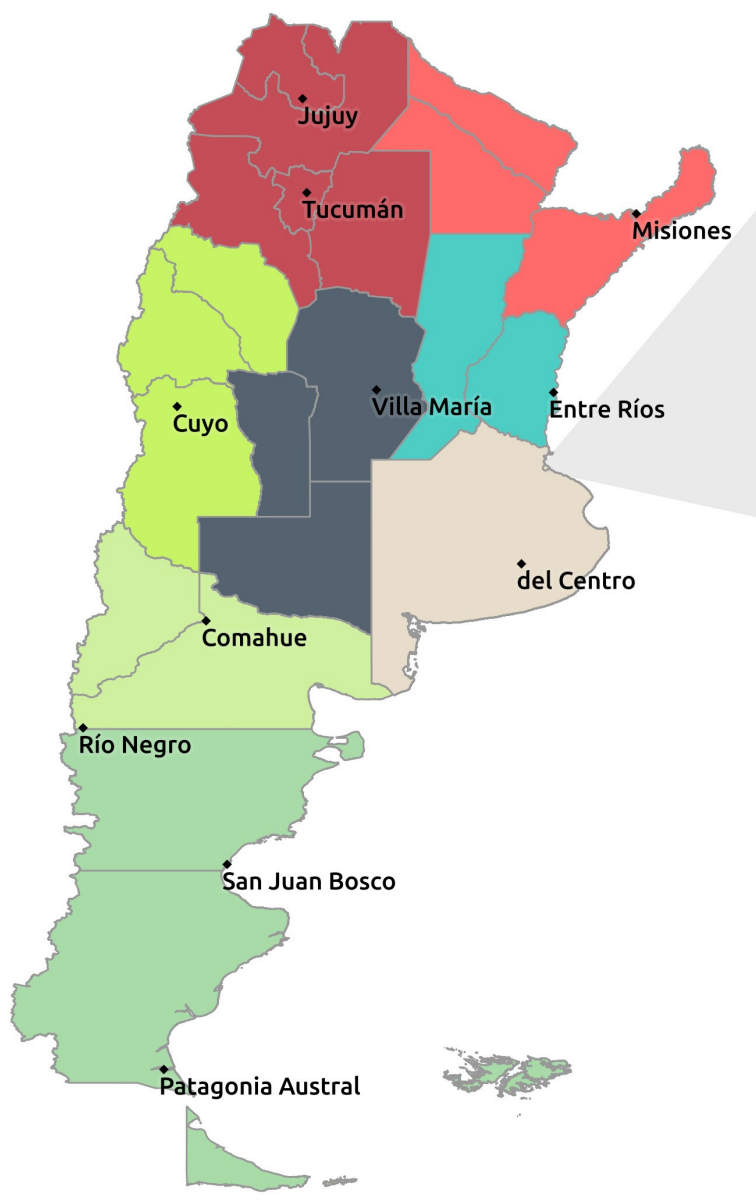

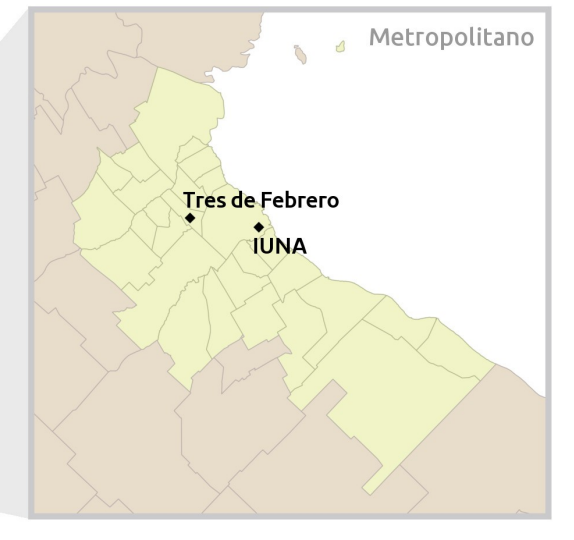

Legenda

Polos Audiovisuais Tecnológicos

Centro

Centro Este

Cuyo

$\square$ Metropolitano

NEA

NOA Patagonia Norte Patagonia Sur

Província de Buenos Aires

- Universidade Nacional coord. do Polo

Elaboração: André Pasti.

A conformação desses Polos e o estabelecimento, posterior, da rede audiovisual federal se baseou em quatro conjuntos de ações: (1) pesquisa e desenvolvimento, para identificar as capacidades instaladas, recursos humanos e necessidades; (2) capacitação, a partir das demandas levantadas; (3) adequação técnica, com atualização tecnológica; e (4) elaboração de um plano piloto para produção de conteúdos e identificação das capacidades de produção de cada lugar (CARBONI; LABATE, 2012).

Na primeira experiência de produção audiovisual do Programa, entre 2010 e 2011, o fomento a novos conteúdos se deu a partir da produção de um 
plano de programas pilotos. Para isso, foram financiadas diversas linhas de programação. Nessa etapa, uma série de medidas normativas foram tomadas para viabilizar direitos e contratações, já que várias produtoras não estavam formalmente constituídas (PAT, 2015). Além disso, era necessário solucionar a questão dos direitos sobre a produção entre autores dos projetos, universidades e CIN. Assim, durante 2011, foram realizadas 90 horas de produção televisiva, distribuídas em todos os Polos, em 31 ciclos televisivos. Os ciclos foram gravados em mais de 150 locais, com atuação de cerca de 500 profissionais e participação de 45 universidades e mais de 200 organizações audiovisuais (PAT, 2015).

Durante esse período, foram sendo conformados os Nós Audiovisuais Tecnológicos (NAT) da rede federal. Esses Nós seriam

centros de produção audiovisual local, coordenados por Universidades Nacionais e integrados por cooperativas, organizações, pequenas e médias empresas, produtoras, emissoras de televisão, sindicatos e órgãos públicos vinculados à indústria audiovisual. Neles, as universidades e a comunidade audiovisual local trabalham juntos para desenvolver e consolidar a indústria audiovisual em cada região do país (PAT, 2015, n.p, tradução nossa).

Os Nós Audiovisuais buscavam promover o encontro dos agentes e capacitá-los para produção de audiovisual, criar condições técnicas e ampliar as possibilidades para o fomento do audiovisual nesses lugares (BERNARDO; GIBEAUD; ELEM, 2016). Merece destaque na proposta de organização dos Nós Audiovisuais seu aspecto participativo ${ }^{68}$. Houve um desenho de metodologia para o trabalho coletivo, já que os Nós pretendiam reunir diversos agentes de diferentes setores da sociedade para a promoção do audiovisual local. Essa proposta foi desenvolvida a partir de uma metodologia de participação popular elaborada por Héctor Poggiese, chamada gestão associada (POGGIESE, 2011, p. 53-62) - de um conjunto de metodologias de planejamento participativo

68 Entrevista de María Álvarez Vicente ao autor, realizada em Buenos Aires em setembro de 2016. Vicente é bacharela em Ciência Política e foi subcoordenadora do Programa Polos Audiovisuales. 
denominado $\mathrm{PPGA}^{69}$. A gestão associada propõe práticas para a gestão participativa associando Estado e sociedade para implementação de políticas sociais e urbanas. Como afirma Poggiese (2011, p. 53, tradução nossa),

\begin{abstract}
A gestão associada alude a uma forma de cogestão entre Estado e sociedade que dá lugar a acordos, negociações ou concertações e ao desenho de propostas, integrando visões e interesses diferentes e mesmo opostos, reconhecendo e trabalhando os conflitos. [...] Promove a mobilização e articulação de atores com peso diferenciado nos projetos e políticos, acordando graus de responsabilidade e compromisso mútuos [...] Prioriza o fortalecimento dos atores mais fracos, cooperando em seu desenvolvimento e capacitação, para reduzir sua desigualdade.
\end{abstract}

O proponente da metodologia e sua instituição, a FLACSO-Argentina, participaram ativamente do desenho institucional e da efetivação da metodologia do programa PAT. A prática metodológica de gestão associada propunha, em síntese, a realização de (1) Plenárias Periódicas, com três ou quatro momentos: quadro de situação e prospectiva; espaço conceitual e propositivo; grupos de trabalho e programação de tarefas; e, se necessário, formação por intercâmbio entre participantes; (2) um Sistema de Registro, produzindo uma ata que inclui as deliberações e produtos dos grupos de trabalho; e (3) Grupos de trabalho, encarregados por temas e projetos específicos identificados a partir do processo participativo (POGGIESE, 2011, p. 58-60).

No programa Polos, a partir dessa metodologia, foi elaborado processo para a fundação de um Nó Audiovisual: era realizado um mapeamento dos principais agentes de cada região - potenciais integrantes da rede -, havia uma convocatória pública e o grupo inicial de agentes era capacitado metodologicamente ${ }^{70}$. O fluxo metodológico para criação de um Nó (17) tinha três

69 O que o autor denomina de 'família de metodologias PPGA' (Planejamento Participativo e Gestão Associada) é um conjunto de propostas metodológicas para a tomada de decisões que incorpora como elemento central a participação social. São práticas baseadas em experiências de processos participativos desenvolvidos na Argentina, no Brasil e em outros países da região, a partir da década de 1970 e na abertura democrática de vários países na década de 1980. A metodologia de gestão associada foi desenvolvida a partir de experiências nas décadas de 1980 e 1990 no Uruguai e na Argentina (POGGIESE, 2011).

70 Entrevistas de Héctor Poggiese e Fabio Omar Oliva ao autor, em setembro e outubro de 2016 em Buenos Aires. 
etapas: convocatória para sua formação, formação metodológica e programação e desenvolvimento da reunião, com registro dos progressos.

\section{Figura 17: Esquema metodológico para criação de um Nó da rede dos Polos Audiovisuais}

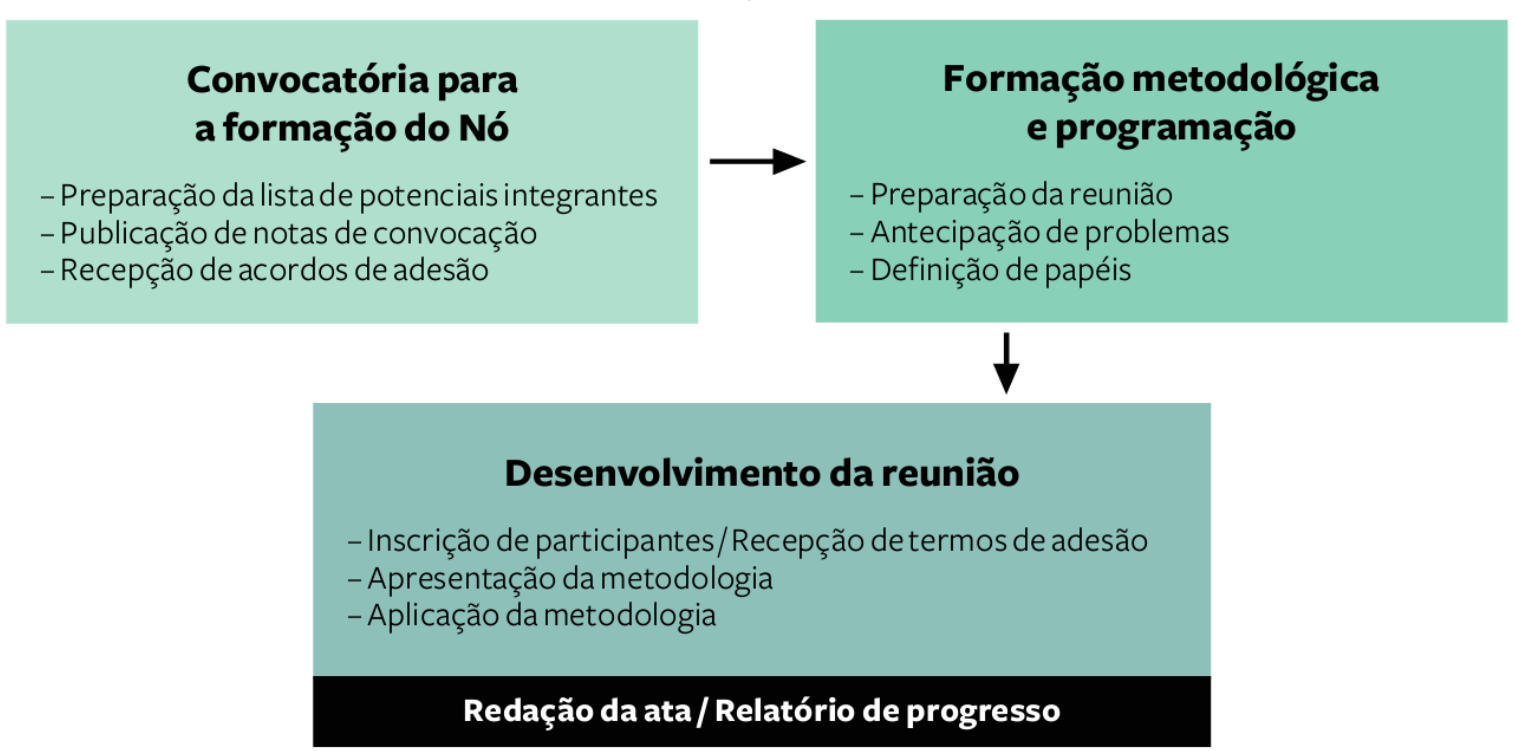

Elaboração própria. Fonte: Acervo do Programa Polos.

A partir de então, eram realizadas plenárias participativas, com redação de atas e informes dos avanços. Nessas plenárias, sempre havia três momentos: (1) rodada de atualização de informes e análise do contexto e conjuntura; (2) rodada propositiva; e (3) momento de programação de atividades. Além disso, conforme propõe a metodologia de gestão associada, havia grupos de trabalhos específicos para certos temas, de acordo com as necessidades identificadas a partir da situação local. A proposta era trabalhar conjuntamente temas para o desenvolvimento do audiovisual local e encontrar caminhos conjuntos para cuidar dos recursos do programa federal, tanto para a produção de conteúdos audiovisuais quanto para equipamentos e outros temas. Ao todo, foram propostos e impulsionados $42 \mathrm{Nós}^{71}$ (Mapa 5), que tiveram, no pouco

Poggiese, pesquisador dos temas da participação popular em políticas públicas e democracia, foi o consultor responsável pela metodologia do Programa Polos Audiovisuais, atuando conjuntamente com a coordenação e treinando as equipes de metodologia dos Nós. Oliva faz parte do grupo de Poggiese e foi responsável por consultoria metodológica de Nós no conurbano bonaerense.

${ }^{71}$ A escassa bibliografia sobre o tema e as entrevistas realizadas trouxeram números conflitantes de Nós Audiovisuais, variando entre 39 e 45. Em alguns casos, não foram considerados novos Nós propostos ao longo do programa e, em outros, foram contabilizados os existentes de forma duplicada. O número definitivo, de 42, 
tempo de vigência do Programa, avanços de distintas qualidades e velocidades de produção, envolvendo cerca de 900 organizações nos processos participativos de trabalho (ARGENTINA, 2015d).

\section{Mapa 5: Nós Audiovisuais impulsionados para a conformação da rede federal do Programa Polos Audiovisuais Tecnológicos}

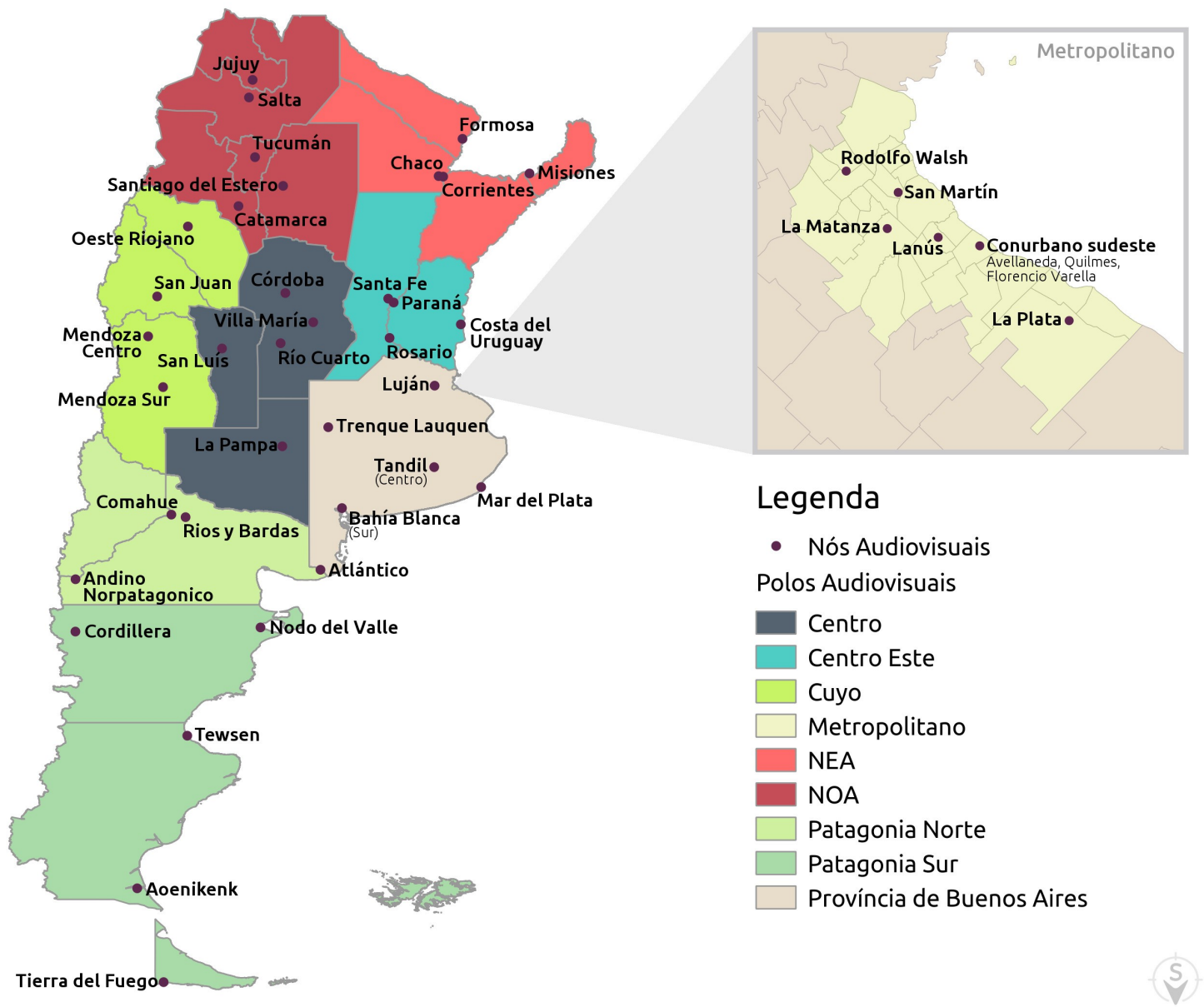

Elaboração: André Pasti.

Observa-se que a rede ideal de Nós Audiovisuais efetiva essa distribuição para o interior do país, buscando a descentralização e a regionalização da produção. Nota-se, ainda, que grande parte dessas localidades são centros urbanos de maior relevância nessas regiões - com destaque às

é baseado nos documentos internos do acervo do programa. 
capitais das províncias. Em geral, trata-se de cidades médias, ou aglomerações de tamanho médio (LAN; MIGUELTORENA, 2017) como Bahía Blanca, Tandil, Mendoza, Santa Fe, Río Cuarto, Comodoro Rivadavia, San Miguel de Tucumán, Paraná, Río Gallegos, Neuquén, Puerto Madryn, Trelew, Corrientes, Salta, Catamarca e outras.

Essas cidades médias se configuram, na divisão territorial do trabalho na Argentina, como nós de intermediação entre a metrópole nacional e o entorno regional (LAN; MIGUELTORENA, 2017, p. 38). Na curta duração do programa, foram escolhidos para a rede de Nós lugares nos quais, apesar das amplas desigualdades com a metrópole de Buenos Aires e de seu papel subordinado na rede urbana argentina e global, havia condições técnicas, materiais e institucionais mais aptas a desenvolver as atividades de produção audiovisual.

Entre a diversidade de agentes participantes dos Nós (18), constavam: instituições educativas, cooperativas de serviço e trabalho do setor audiovisual, ONGs, pequenas e médias empresas do audiovisual, instituições públicas (CARBONI; LABATE, 2012), além de sindicatos, pequenos canais de TV e rádio locais públicos ou comunitários e as próprias universidades (PAT, 2012). 
Figura 18: Organizações ativas nos Nós Audiovisuais em 2012, por tipo e quantidade

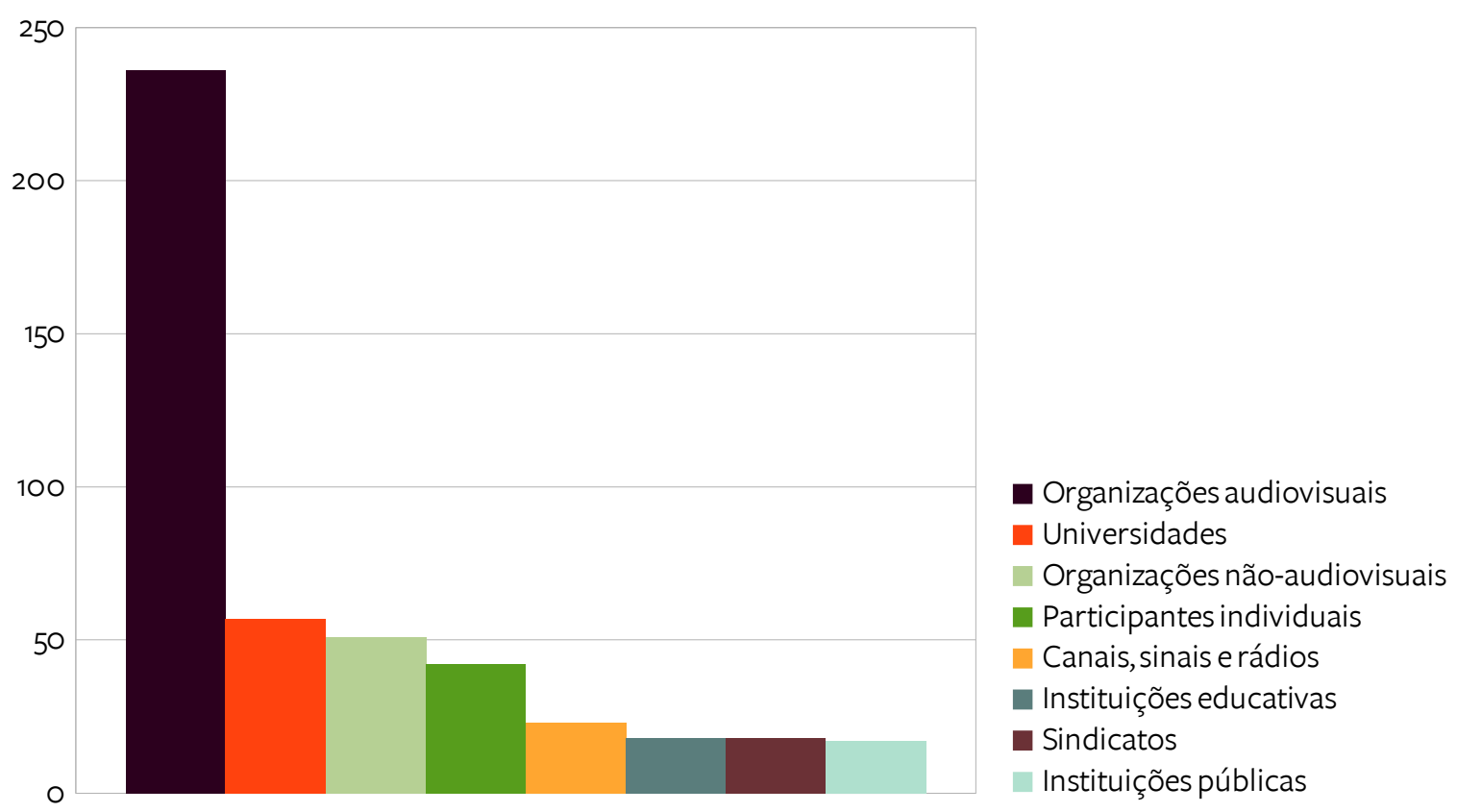

Elaboração própria. Fonte: Acervo do Programa Polos.

O levantamento de dados das organizações participantes em 2012 (18) permite verificar a centralidade de organizações ligadas ao audiovisual, mas também a presença de outras organizações da sociedade civil, entidades ligadas à educação - sobretudo Universidades - e outras instituições. Cabe registrar que a participação das organizações por Nó Audiovisual variou em cada realidade local - havia, em 2014, entre 4 e 22 organizações credenciadas formalmente nos diferentes Nós (Mapa 6). 
Mapa 6: Organizações que aderiram formalmente aos Nós Audiovisuais (2014)
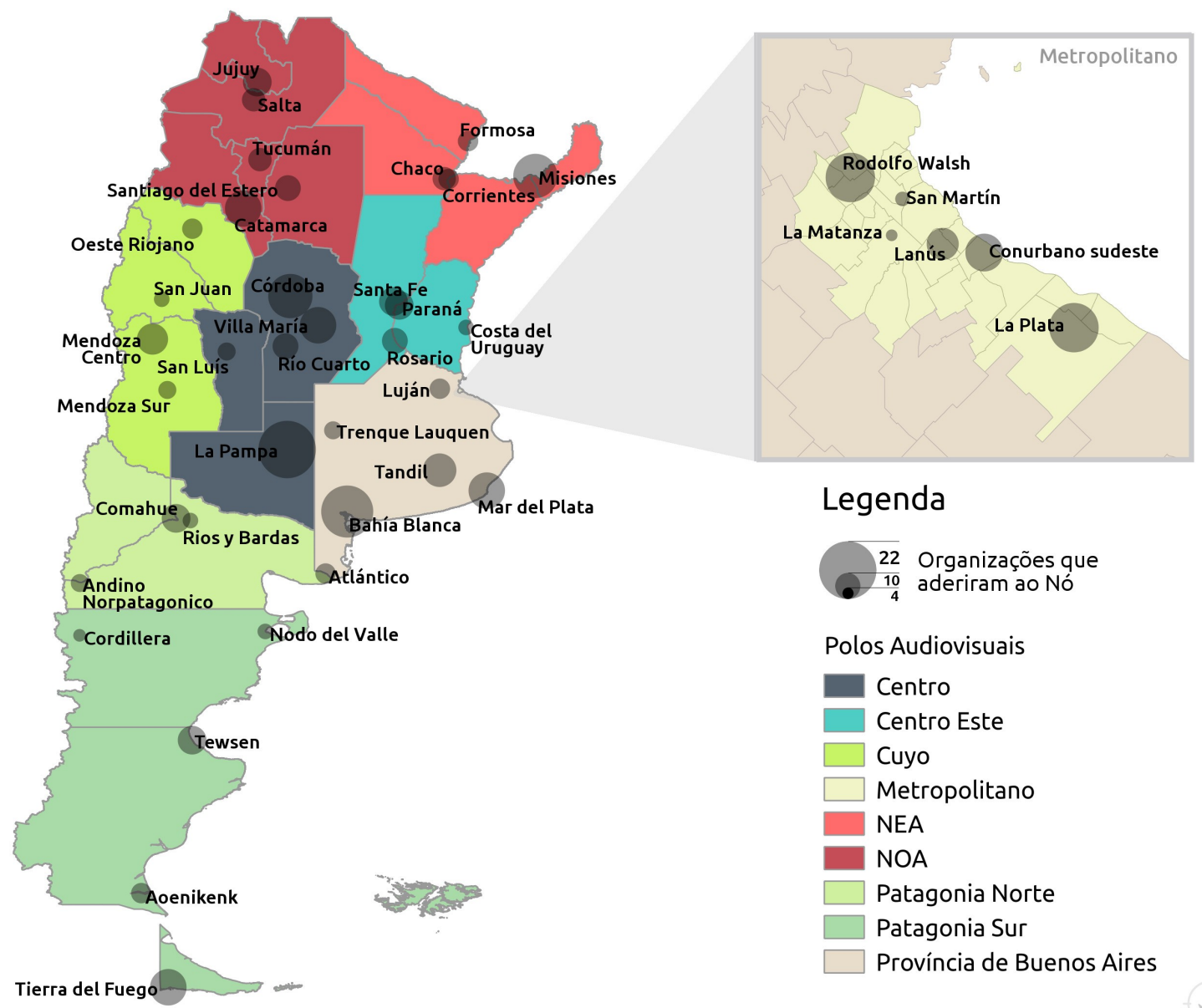

Elaboração: André Pasti.

Desenvolvido com os softwares livres QGIS e GIMP.

Fonte: Acervo do Programa.

Observa-se que alguns Nós como La Pampa, Bahía Blanca, Misiones, Córdoba, La Plata e Rodolfo Walsh (General Sarmiento) possuíam maior quantidade de organizações registradas - o que indicava êxito das convocatórias, ainda que, por si só, isso não garantia que o processo participativo teria sucesso em seus objetivos.

O processo de funcionamento dos Nós era baseado na promoção de condições para a articulação e diálogo entre os agentes do lugar interessados na comunicação audiovisual, com pautas e recursos vindos da coordenação nacional do Programa, por parte do Estado. As ações em busca de impulsionar a 
produção de audiovisual a partir dos lugares envolviam financiamento de produções, capacitação, equipamentos, articulação com canais locais, entre outras. Uma dessas ações foi a proposta de conformação de Centros Públicos de Produção Audiovisual (CEPAs), estúdios com equipamentos de gravação em alta definição para televisão digital (Mapa 7).

\section{Mapa 7: Centros Públicos de Produção Audiovisual (CEPAs) instalados}

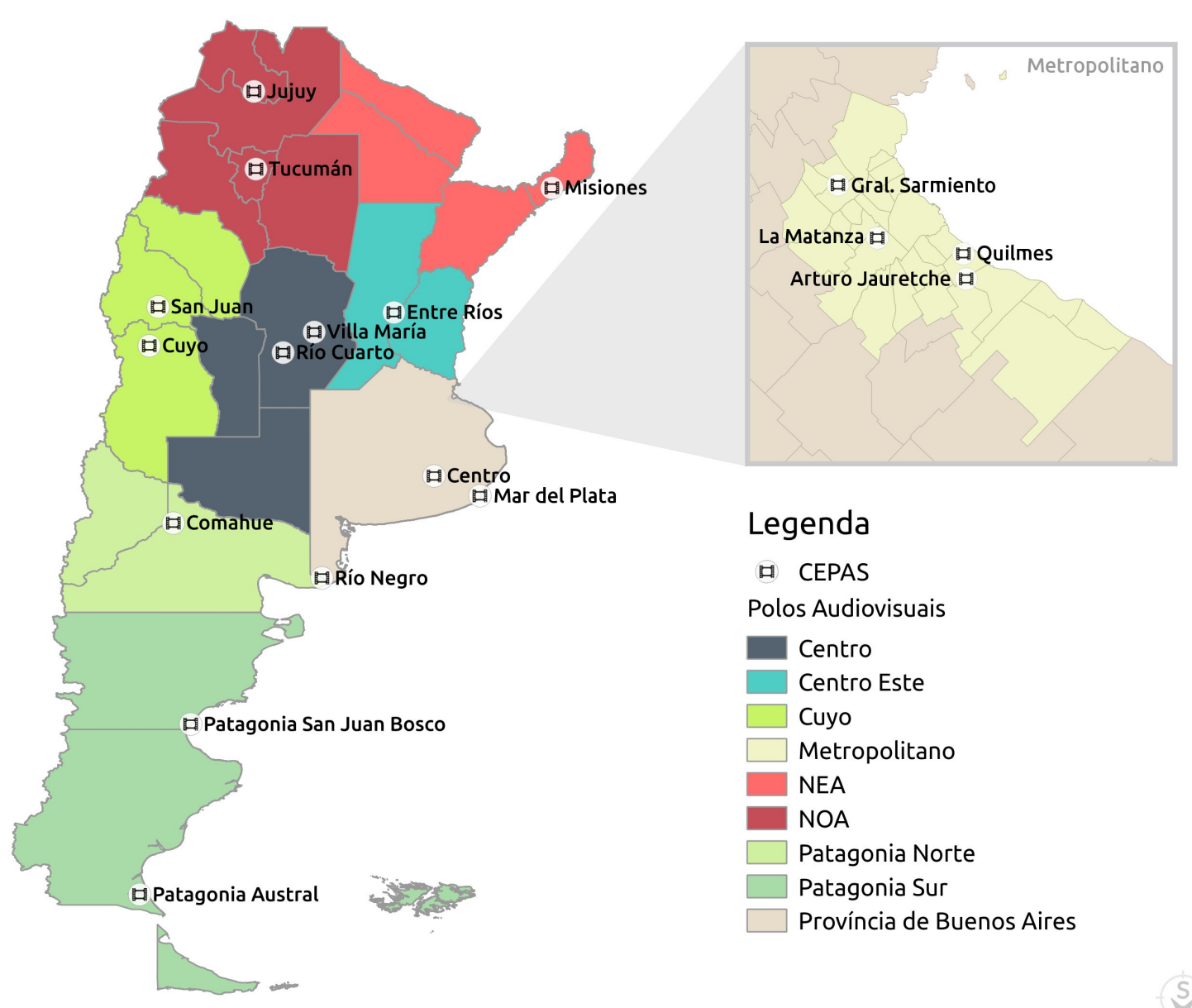

Elaboração: André Pasti. Desenvolvido com os softwares livres QGIS e GIMP.

Fonte: Acervo do Programa.

No total, foram 18 CEPAs instalados ${ }^{72}$ durante a duração do programa, como pode ser observado. Cada Polo (região) recebeu ao menos um CEPA e os Polos Metropolitano e da província de Buenos Aires foram os que mais

72 Entrevista de Muriel Bernardo, Eliane Gibeaud e Vivian Elem ao autor, na sede do Ministério de Planejamento da Argentina em 27 de janeiro de 2016. Elas integravam a equipe do Programa Polos. 
concentraram esses centros. A proposta era ter um espaço adequado à produção audiovisual digital em alta definição, que pudesse ser utilizado por agentes da sociedade interessados na comunicação. Houve uma série de tratativas entre os agentes envolvidos no programa buscando constituir um regulamento para os CEPAs. Em versão aprovada pelo Conselho Assessor da TDA em 2013, o objetivo dos CEPAs constava como:

Democratizar o acesso, a favor dos atores do setor televisivo incorporados aos PAT [Polos Audiovisuais Tecnológicos], ao equipamento necessário à produção de conteúdos audiovisuais para a televisão digital, a fim de promover a igualdade de oportunidades no acesso à mesma qualidade de produção e serviços tecnológicos, promovendo as condições equitativas de produção federal (CONSEJO ASESOR TDA, 2013, cap. 1).

Este regulamento previa que poderiam acessar os CEPAs agentes do setor audiovisual e televisivo local e regional que integram os Nós Audiovisuais, outros agentes do audiovisual regional e de fora da região, e organizações participantes de outros Nós Audiovisuais. As prioridades estabelecidas eram: (1) membros dos Nós do Polo em questão, em projetos coletivos do programa; (2) a Universidade sede, membros do Nó em projetos particulares e outros atores regionais; (3) membros de Nós de outros polos, para projetos coletivos do programa; e (4) outros agentes fora da região, buscando a não-ociosidade do espaço. Os agentes da prioridade 1 e 3 pagariam 25\% dos custos como taxa, enquanto da prioridade $2,50 \%$ da taxa, e prioridade 4, 100\% - com exceção da própria Universidade, onde não haveria taxa. As Universidades que abrigam os CEPAs seriam responsáveis por planejar os usos, dispondo de pessoal para administração. Um dos conflitos relatados nas entrevistas entre os agentes coordenadores do Programa se deu em torno desse regulamento, como será visto adiante.

Entre as ações para fomento da produção audiovisual nos Nós, após o Plano Piloto, um segundo ciclo de produção audiovisual foi realizado entre $2012 \mathrm{e}$ 2013, com a chamada Fábrica de TV, que consistia em 
um exercício de integração ao novo paradigma comunicacional que busca promover a produção federal de conteúdos, ao mesmo tempo em que produz linhas de conteúdos televisivos de qualidade, exercita os tempos de produção de acordo com os prazos televisivos e fomenta a produção em rede em todo o território nacional para conseguir, deste modo, a renovação e democratização da produção de conteúdos televisivos (SEL, 2013, p. 143).

Foram quatro linhas de produção nesse período: uma ligada à criação de novos formatos para o audiovisual; uma linha para o canal da TDA Acua Mayor, voltado à população idosa; uma para uma campanha educativa do Ministério da Educação (Acompaña tus hijos a la escuela); e uma linha jornalística para produzir um noticiário federalizado (programa Ahi va) (PAT, 2015). Visando a sustentabilidade econômica dos projetos, a proposta era financiar as linhas por um conjunto de tempo - 12 episódios -, para criação de audiência e incentivo para que buscassem formas de financiamento posteriores nos lugares - concepção alinhada com a proposta de promover indústrias culturais regionais (BERNARDO; GIBEAUD; ELEM, 2016).

Na linha de Novos Formatos, foram apresentados 90 projetos, por 33 Nós de diferentes Polos. Desses, 75 projetos receberam oficinas específicas de capacitação, ministradas por 31 profissionais de distintas áreas. Ao final, 55 projetos foram aprovados por uma Comissão ad hoc e designados aos Nós (PAT, 2015). No caso da linha de programas para o canal Acua Mayor, foram, ao todo, 29 Nós os que produziram. Nove Nós participaram da produção da linha do Ministério da Educação. No caso do piloto do projeto de revista audiovisual jornalística (Ahi va), os 39 Polos então consolidados participaram da rede de produção (19). 
Figura 19: Participação dos Nós Audiovisuais em produções da Fábrica de TV
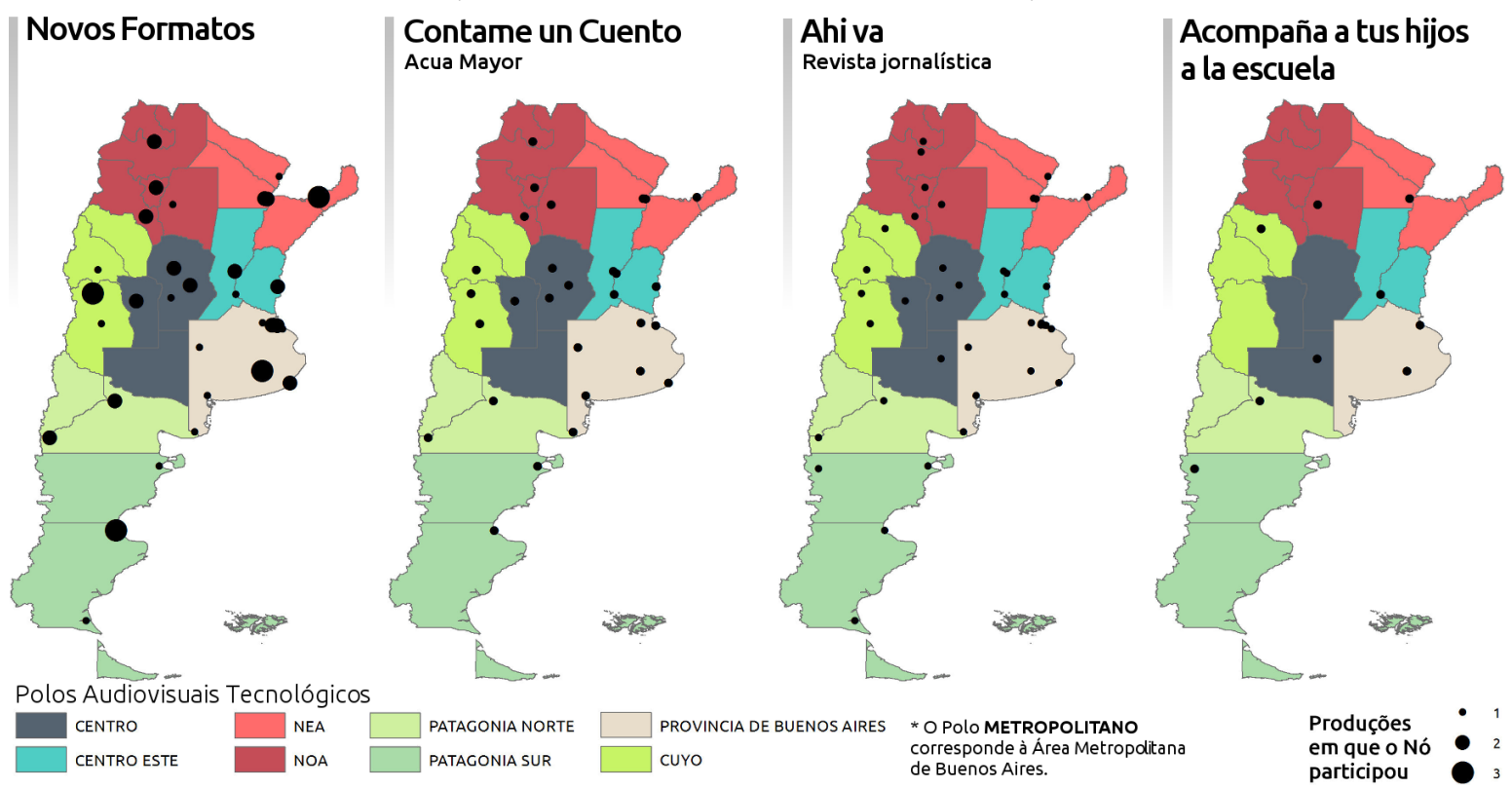

Elaboração: André Pasti. Fonte: Polos (2015).

Observa-se que há alguns Nós Audiovisuais com maior produção quantitativa, como Tandil (Província de Buenos Aires), Chaco (NEA) e Rios y Bardas (Patagonia Norte). Além desses, participaram de todas as linhas de produção os Nós de Santiago del Estero (NOA) e Rosário (Centro Este), e outros como CatamarcAmarca (NOA), Mendonza Centro (Polo Cuyo), Misiones (NEA) e Tewsen (Patagonia Sur) tiveram atuação expressiva. Outros, como Salta (NOA) e General Sarmiento (Metropolitano), participaram apenas da linha Ahi Va.

Durante 2014 e 2015, o Programa Polos sustentou a produção de alguns ciclos surgidos na linha Novos Formatos da Fábrica de TV em 2012 (PAT, 2015, p. 5). Os pilotos desenvolvidos, desenhados para serem veiculados na televisão local e regional obrigaram os Nós Audiovisuais a pensar e aprender sobre audiência, necessidades das grades de programação e patrocinadores (ARGENTINA, 2013b; SEL, 2013). Considerando os altos custos da produção audiovisual dos conglomerados, a pretensão do programa era criar formatos de produção mais baratos e acessíveis para os lugares, conforme entrevistas realizadas (BERNARDO; GIBEAUD; ELEM, 2016; PIWOWARSKI, 2016; VICENTE, 2016), além 
de trocar as experiências na rede estabelecida pelos Nós Audiovisuais.

Para ilustrar os tipos de programas produzidos (20), cabe citar: revistas regionais, como Ideas en Trama, que aborda a cultura de Santiago del Estero, Invenciones, sobre inventores de Mendoza, e a revista culinária Waykuna Wasi, de Jujuy, sobre gastronomia andina; ficções, como Casi un mismo techo, de Misiones, passada na região da fronteira, Habitación 13, de Santa Fe, e Dos Estrellas, comédia em hotel de Mar del Plata; e temáticos como En tus zapatos, sobre o cotidiano de pessoas com deficiência, Miniperiodistas, onde crianças investigam ecologia na Patagônia e La inutilidad del conocimiento, ambientado na Patagônia, explorando como o conhecimento constrói nossa realidade.

Figura 20: Algumas das séries televisivas produzidas a partir do Programa Polos

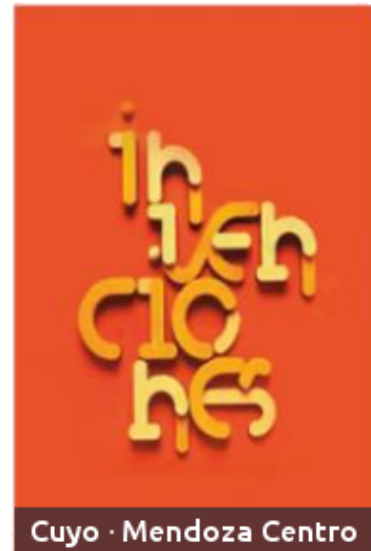

Invenciones

13 capítulos, $26 \mathrm{~min}$

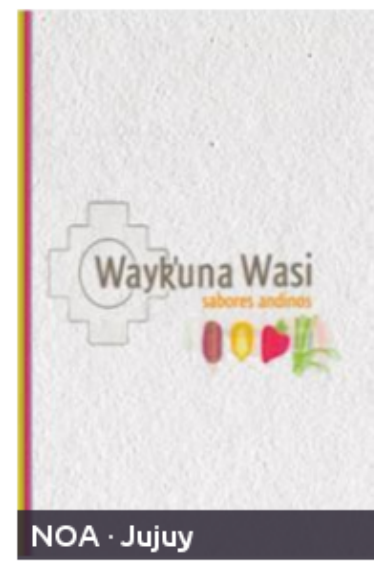

Waykuna wasi - Sabores andinos 12 capítulos, 26 min

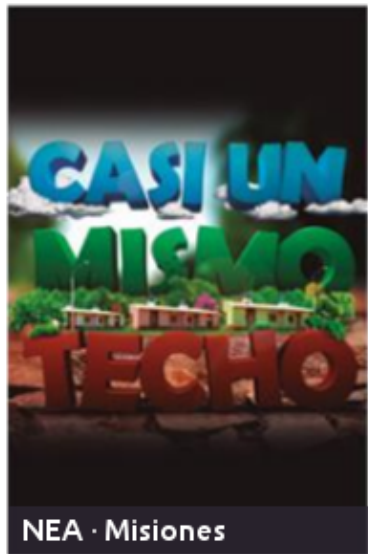

Casi un mismo techo

12 capitulos, $26 \mathrm{~min}$

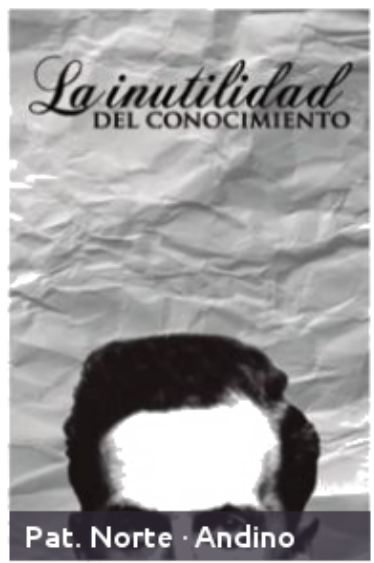

La inutilidad del conocimiento 8 capítulos, 26 min

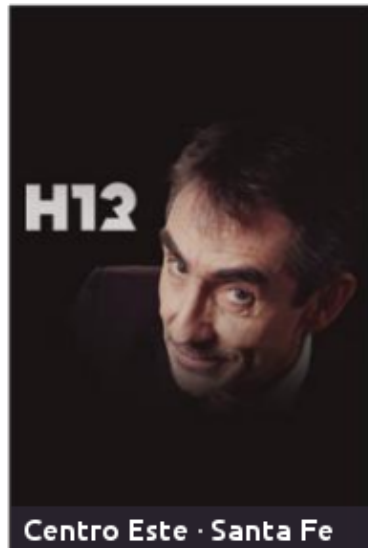

\section{Habitación 13}

13 capitulos, $26 \mathrm{~min}$

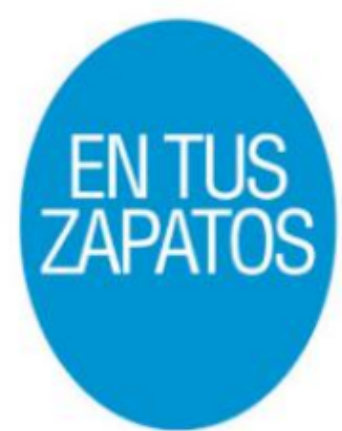

NEA - Corrientes

En tus zapatos

12 capítulos, 26 min

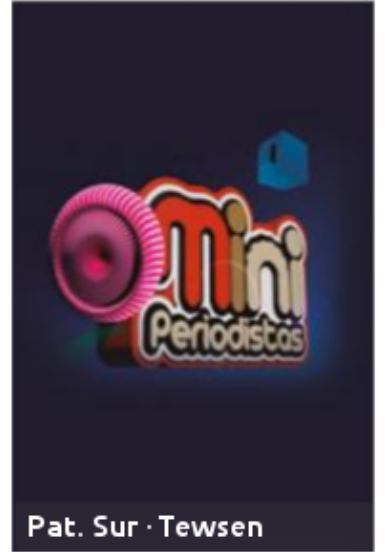

Miniperiodistas

12 capítulos, 26 min

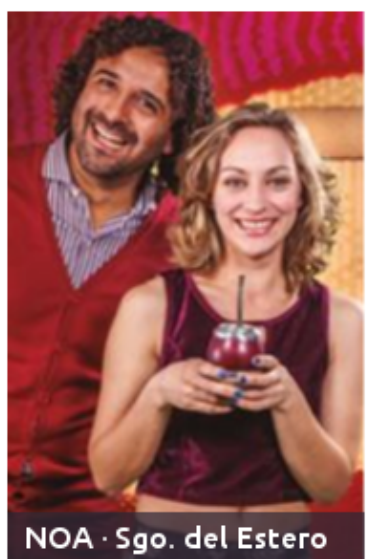

Ideas en trama

12 capítulos, $26 \mathrm{~min}$

Elaboração: André Pasti. Fonte: BACUA (TDA, 2015a). 
Albornoz e Cañedo (2016, p. 197-198) afirmam que o conjunto de produções resultantes do programa apontam para um compromisso em refletir a identidade cultural das regiões e localidades onde foram realizadas e que as dezoito séries que chegaram a ser exibidas na televisão (Quadro 10) dão conta de uma diversidade geográfica de fontes em termos de variedade e equilíbrio.

\section{Quadro 10: Programas dos Nós Audiovisuais veiculados em canais locais}

\begin{tabular}{|c|c|c|c|c|}
\hline Polo & Nó & Programa & Conteúdo / Formato & Gêneros / Classificação \\
\hline \multirow[t]{2}{*}{ Centro } & San Luis & Jóvenes Vocaciones & $\begin{array}{l}\text { Programa sobre jovens } \\
\text { descobrindo suas carreiras }\end{array}$ & $\begin{array}{l}\text { Revista, Educativo, } \\
\text { Entrevistas }\end{array}$ \\
\hline & Villa María & $\begin{array}{l}\text { Vale la pena } \\
\text { conocernos }\end{array}$ & $\begin{array}{l}\text { Revista com entrevistas com } \\
\text { pessoas da província }\end{array}$ & Sociedade, Entrevitas, Revista \\
\hline $\begin{array}{l}\text { Centro } \\
\text { Este }\end{array}$ & Santa Fe & Habitación 13 & $\begin{array}{l}13 \text { histórias de diferentes } \\
\text { épocas no mesmo lugar. }\end{array}$ & $\begin{array}{l}\text { Ficção, Drama, Humor, } \\
\text { Comédia, Suspense }\end{array}$ \\
\hline \multirow[t]{2}{*}{ Cuyo } & $\begin{array}{l}\text { Mendoza } \\
\text { Centro }\end{array}$ & Invenciones & $\begin{array}{l}\text { Apresenta invenções e } \\
\text { inventores mendozinos }\end{array}$ & $\begin{array}{l}\text { Revista, Entretenimento, } \\
\text { Jornalismo }\end{array}$ \\
\hline & & Los buscadores & $\begin{array}{l}\text { Entrevistas e histórias de } \\
\text { pessoas e temas de Mendoza }\end{array}$ & $\begin{array}{l}\text { Arte e cultura, Entrevistas, } \\
\text { Revista, Sociedade, Música }\end{array}$ \\
\hline \multirow[t]{2}{*}{$\begin{array}{l}\text { Metropo- } \\
\text { litano }\end{array}$} & La Matanza & Verde otra manera & $\begin{array}{l}\text { Revista sobre ecologia e meio } \\
\text { ambiente }\end{array}$ & $\begin{array}{l}\text { Ecologia, Meio ambiente, } \\
\text { Entrevistas, Revista }\end{array}$ \\
\hline & La Plata & El mejor plan & $\begin{array}{l}\text { Ciclo sobre cena artística e } \\
\text { cultural de La Plata e região }\end{array}$ & $\begin{array}{l}\text { Arte e cultura, Sociedade, } \\
\text { Cinema, Entrevistas }\end{array}$ \\
\hline \multirow[t]{4}{*}{ NEA } & Corrientes & En tus zapatos & $\begin{array}{l}\text { Série sobre se colocar no lugar } \\
\text { de pessoas com deficiência }\end{array}$ & $\begin{array}{l}\text { Documentário, Sociedade, } \\
\text { Saúde, Inclusão }\end{array}$ \\
\hline & & En el patio & $\begin{array}{l}\text { Ciclo sobre a diversidade da } \\
\text { identidade de Corrientes }\end{array}$ & $\begin{array}{l}\text { Arte e Cultura, Revista, } \\
\text { Entrevistas, Música, Religião }\end{array}$ \\
\hline & Misiones & Casi el mismo techo & $\begin{array}{l}\text { Cotidiano de habitantes de um } \\
\text { bairro entre fronteiras }\end{array}$ & Ficção, Comédia, Humor \\
\hline & & Revolución en estéreo & $\begin{array}{l}\text { Ciclo sobre músicos de } \\
\text { Misiones }\end{array}$ & $\begin{array}{l}\text { Música, Arte e cultura, } \\
\text { Entrevistas }\end{array}$ \\
\hline \multirow[t]{2}{*}{$\mathrm{NOA}$} & Jujuy & $\begin{array}{l}\text { Waikuna wasi - } \\
\text { sabores andinos }\end{array}$ & $\begin{array}{l}\text { Revista culinária da cultura } \\
\text { típica do noroeste argentino }\end{array}$ & $\begin{array}{l}\text { Gastronomia, Revista, } \\
\text { Entrevistas }\end{array}$ \\
\hline & $\begin{array}{l}\text { Santiago del } \\
\text { Estero }\end{array}$ & Ideas en trama & $\begin{array}{l}\text { Revista - diversidade cultural } \\
\text { de Santiago del Estero }\end{array}$ & $\begin{array}{l}\text { Arte e cultura, Revista, } \\
\text { Entrevistas }\end{array}$ \\
\hline $\begin{array}{l}\text { Patagonia } \\
\text { Norte }\end{array}$ & Andino & $\begin{array}{l}\text { La inutilidad del } \\
\text { conocimiento }\end{array}$ & $\begin{array}{l}\text { Ciclo que levanta questões } \\
\text { sobre diversos temas sociais }\end{array}$ & $\begin{array}{l}\text { Documentário, Sociedade, } \\
\text { Ciências sociais, Revista }\end{array}$ \\
\hline \multirow[t]{2}{*}{$\begin{array}{l}\text { Patagonia } \\
\quad \text { Sur }\end{array}$} & Aonikenk & Sonido Sur & $\begin{array}{l}\text { Revista sobre músicos e } \\
\text { instrumentos da Patagônia }\end{array}$ & $\begin{array}{l}\text { Música, Arte e cultura, } \\
\text { Revista, Educativo }\end{array}$ \\
\hline & Tewsen & Miniperiodistas & $\begin{array}{l}\text { Jovens alunos realizam blog } \\
\text { sobre ecologia na Patagônia }\end{array}$ & $\begin{array}{l}\text { Revista, Ecologia, Educativo, } \\
\text { Sociedade }\end{array}$ \\
\hline \multirow{2}{*}{$\begin{array}{l}\text { Província } \\
\text { de Buenos } \\
\text { Aires }\end{array}$} & Mar del Plata & Dos estrellas & $\begin{array}{l}\text { Ficção que se passa em hotel } \\
\text { de Mar del Plata }\end{array}$ & Ficção, Comédia \\
\hline & Tandil & Telepípedo & Série humorística & Fiç̧ão, Humor, Comédia \\
\hline
\end{tabular}


Observa-se em vários programas a vinculação das propostas com distintas situações dos lugares, como em revistas de diversidade cultural, artística e culinária das regiões - programas como Ideas en Trama, Waikuna wasi e En el patio, El mejor plan e Vale la pena conocernos - e representações de cotidianos atravessados por situações de fronteira - ficção Casi el mismo techo ou pelo papel das cidades na rede urbana - caso da ficção sobre trabalhadores do turismo em Mar del Plata, por exemplo.

Segundo Piwowarski (2016), a proposta desse conteúdo regional era trazer elementos reais dos cotidianos desses lugares, superando a lógica da região como paisagem natural, que marcaria os estereótipos regionais argentinos. Várias das produções articulam questões como dar voz a agentes do lugar, representar diferentes sotaques, evidenciar a diversidade cultural local e exibir outras paisagens urbanas e rurais.

Enquanto o programa buscou enraizar-se em nível local, por outro lado, Albornoz e Cañedo (2016, p. 193) destacam que ele foi mais pensado em relação à capacitação e à produção de conteúdos do que na difusão e promoção dos mesmos. Conforme Piwowarski (2016), houve ações de busca ativa de parceiros e canais locais, além das ações para disponibilização das produções na plataforma BACUA. No entanto, a falta de janelas de exibição foi apontada como um dos limites à circulação das produções. Como afirmam os autores já citados, o PAT não foi capaz de acabar com a falta de visibilidade da produção televisiva regional e local (ALBORNOZ; CAÑEDO, 2016, p. 198). Cabe considerar, ainda, que o programa se articulava com outras ações voltadas à ampliação do número de canais que, no pouco tempo de vigência e com os obstáculos já tratados, não efetivaram a criação de uma grande quantidade de canais no interior do país.

Poucas pesquisas trataram sobre o desenvolvimento do programa em situações geográficas da Argentina - foi o caso dos Nós Audiovisuais de Jujuy, no Polo NOA (GARCÍA VARGAS, 2015; GARCÍA VARGAS; BURGOS, 2011), de Aonikenk, no Polo Patagonia Sur (RAMOS; FRANCISCOVIC, 2013), do Polo 
Província de Buenos Aires (GONZALEZ; GARCÍA GERMANIER, 2014) e do Nó Córdoba, do Polo Centro (MOTTA; MORERO; MOHADED, 2015). Será analisado brevemente, a seguir, o caso do Nó Misiones, no Polo NEA ${ }^{73}$.

\title{
4.1.2. Comunicação ascendente na situação geográfica do Nó Audiovisual Misiones
}

As históricas desigualdades socioespaciais entre as regiões do território argentino se articulam com distintas condições nas situações geográficas correspondentes aos Nós Audiovisuais. Assim, é de se esperar que uma política de regionalização da produção audiovisual encontre condições das mais diversas para sua efetivação nos lugares.

No entendimento de Silveira (1999b, p. 22), a situação geográfica é vinculada à noção de evento geográfico. Baseada no entendimento de evento geográfico de Santos (2006), a autora entende que

\begin{abstract}
uma situação geográfica supõe uma localização material e relacional (sítio e situação), mas vai além porque nos conduz à pergunta pela coisa que inclui o momento da sua construção e seu movimento histórico. [...] Constrói-se, a cada momento histórico, uma extensão dos fenômenos no lugar, que é uma manifestação da coerência do real. A situação decorreria de um conjunto de forças, isto é, de um conjunto de eventos geograficizados, porque tornados materialidade e norma. Muda, paralelamente, o valor dos lugares porque muda a situação, criando uma nova geografia. Assim, ao longo do tempo, os eventos constroem situações geográficas que podem ser demarcadas em períodos e analisadas na sua coerência.
\end{abstract}

Encontrando a organização espacial herdada historicamente, os eventos, ao se geografizarem, recriam novos conjuntos de possibilidades no lugar para o futuro - para Ribeiro (2015, p. 163), “a situação geográfica é uma análise das existências cuja compreensão está ancorada no futuro". Entendendo a LSCA como um evento geográfico e o programa Polos Audiovisuais Tecnológicos como parte desse evento, servindo como estrutura organizacional e territorial para sua

73 Além do Nó Misiones, foram realizados trabalhos de campo no Nó Conurbano Sudeste (Polo Metropolitano) e
conversas com integrantes de atividades do programa em outros Polos. 182 | Promoção da comunicação ascendente no território argentino 
efetivação nos lugares, toma-se, aqui, a situação geográfica do Nó Audiovisual Misiones do Polo NEA como caso de análise.

Muito antes desse evento, é fundamental resgatar as especificidades da formação da região do nordeste argentino no que tange à produção e circulação de informações e a sucessão de eventos ligados à comunicação audiovisual que caracterizam a situação particular do Nó Misiones. Trata-se de um espaço fronteiriço que engloba Argentina, Paraguai e Brasil. Partindo do entendimento de Milton Santos, Benedetti (2014, p. 43, tradução nossa) afirma que

\begin{abstract}
A fronteira pode ser entendida como um conjunto indissociável, solidário e contraditório, de objetos e ações [...] Nesta linha, o espaço fronteiriço constitui uma noção genérica, que inclui às fronteiras adjacentes, de cada um dos territorios justapostos, que se articulam de alguma maneira e que engendram uma nova entidade, bipartite ou tripartite. A fronteira de cada território surge como ação de um ou reação frente ao outro; é espelho e reflexo da vizinha. Os componentes básicos de um espaço fronteiriço são o limite internacional e as duas fronteiras adjacentes. Territórios interiores de governo, territórios produtivos transfronteiriços, lugares de fronteira e caminhos são outros dos tantos elementos que participam na configuração do espaço fronteiriço como sistema.
\end{abstract}

Em entrevista, Axel Monsu ${ }^{74}$ reforçou que o processo de criação de uma cena audiovisual ${ }^{75}$ em Misiones precede o Programa Polos. Uma das experiências precursoras no audiovisual misioneiro teria se desenvolvido a partir do Sistema Provincial de Teleducación y Desarrollo (SIPTED) - instituição responsável por ações de educação formal e não-formal pela televisão, onde se formaram e atuaram vários profissionais do setor, conforme entrevista com a

${ }_{74}$ Entrevista de Axel Monsu ao autor, em novembro de 2016, em Posadas (Província de Misiones). Monsu é produtor audiovisual, sócio-fundador da Productora de la Tierra, organizador do festival "Oberá en Cortos" pela Identidade e Diversidade Cultural - Festival Internacional de Curtas-metragens e Encontro de Produtores Audiovisuais e coordenador do Instituto de Artes Audiovisuales de Misiones (IAAVIM).

75 Analisando o caso da música, Alves (2015) propõe o entendimento da cena referindo-se à espessura que uma manifestação artística adquire num dado lugar. As características do audiovisual em Misiones nas décadas de 2000 e 2010 permitem identificar ali uma cena audiovisual. 
cineasta Ana Zanotti ${ }^{76}$. Na mesma direção, Zamboni (2015, p. 20, tradução nossa) afirmou que

\begin{abstract}
em um contexto promissor para a atividade audiovisual na província, a partir da implementação da Lei de Serviços de Comunicação Audiovisual e do desenvolvimento desde 2010 do programa Polos [Audiovisuais] Tecnológicos [...], torna-se fundamental que a produção do SiPTeD seja devidamente revalorizada, readequada e utilizada, já que contém conteúdos vitais da memória da província e da região em suporte audiovisual.
\end{abstract}

O SIPTED foi criado em 1984, vinculado ao Ministério de Educação e Cultura de Misiones, criando peças audiovisuais que foram difundidas de diversas formas - fitas de videocassetes para uso nas residências e outras localidades, exibição em centros comunitários chamados de teleclubes e nos canais televisivos (ZAMBONI, 2015, p. 1-3). Foi uma política pública que contribuiu para a criação de diversos produtos audiovisuais sobre a província, com documentários, ficções e dramatizações com marcado caráter local e regional dos temas e com uma busca por desvendar aspectos da identidade misioneira (ZAMBONI et al., 2014, p. 62). Segundo Zanotti (2016), no início da década de 1980, ainda não havia cursos de comunicação social, cinema ou audiovisual na província, e os produtores formavam-se em outros centros, como Córdoba ou Buenos Aires.

Durante os anos 1990 e o início dos anos 2000, as produções audiovisuais da província eram predominantemente marcadas por ações independentes e por conta dos realizadores. Alguns cursos ligados ao audiovisual foram surgindo na província, como na faculdade privada católica chamada Instituto Montoya (ZANOTTI, 2016). Nos anos 2000, a participação de vários agentes em redes de produção audiovisual se somou a políticas públicas nacionais e no âmbito do Mercosul, articulada sobretudo na região fronteiriça. Conforme Monsu (2016), desde 2003, a cidade de Oberá reúne produtores

76 Entrevista de Ana Zanotti ao autor, realizada em novembro de 2016 em Posadas (Província de Misiones). Zanotti é antropóloga e cineasta documentarista e faz parte da associação de produtores audiovisuais chamada Red de Realizadores de la Provincia de Misiones, que conta com mais de 60 profissionais. 
audiovisuais no festival de curtas-metragens Oberá en Cortos. O encontro foi criando vínculos na região da fronteira, especialmente com Paraguai e Brasil. A partir desses vínculos, desde 2006 o festival abrigava o Espaço Entre Fronteiras que tinha como objetivo "fortalecer o desenvolvimento de um polo regional de produção [audiovisual], propiciando um espaço de encontro e comunicação para produtores, realizadores, exibidores e distribuidores da região, buscando alternativas para viabilizar projetos audiovisuais" (OBERÁ EN CORTOS, 2007). Em 2007, o espaço virou Fórum Entre Fronteiras (REBELATTO; FONSECA, 2015). O Fórum

\begin{abstract}
nasceu em um contexto de consolidação dos festivais de cinema na região Sul do Brasil, noroeste da Argentina e com realizadores do Paraguay. A partir de encontros entre organizadores do Festival Santa Maria Vídeo e Cinema (Santa Maria, RS, Brasil), Festival Oberá en Cortos (Oberá, Misones, na Argentina) e Lapacho (Resistência, Chaco, na Argentina) forma-se um grupo de idealizadores deste projeto. [...] Refletindo toda a cadeia produtiva e formativa do audiovisual, o fórum entre fronteiras se propôs ainda a sistematizar formas de criar e garantir sistemas de exibição, distribuição, difusão e comercialização das produções independentes regionais (REBELATTO; FONSECA, 2015, p. 6-9).
\end{abstract}

Paralelamente, organizavam-se iniciativas do Mercosul para o audiovisual. Em 2003, surgiu o Fórum de Autoridades Cinematográficas do Mercosul e, em novembro do mesmo ano, era apresentado o projeto de criação da Reunião Especializada de Autoridades Cinematográficas e Audiovisuais do Mercosul - RECAM, um órgão consultivo formado por representantes dos órgãos nacionais de cinema dos países membros e associados do Mercosul (CANEDO; LOIOLA; PAUWELS, 2015, p. 9). A proposta foi aprovada em dezembro de 2003. Cabe ressaltar que Eva Piwowarski, que futuramente tornou-se coordenadora do Programa Polos Audiovisuais Tecnológicos, participou dos esforços para a criação da RECAM e posteriormente dirigiu o programa Mercosul Audiovisual. A articulação entre o Fórum Entre Fronteiras e a RECAM potencializou as relações entre os agentes ligados ao audiovisual na região da tríplice fronteira - em 2007, 
uma das mesas do espaço Entre Fronteiras do festival Oberá en Cortos tratou sobre "Polos de produção a partir dos recursos regionais" e foi coordenada por Piwowarski (OBERÁ EN CORTOS, 2009).

Zanotti (2016) apontou como um momento marcante ao audiovisual regional, ligado à experiência do Fórum Entre Fronteiras, o projeto de coprodução audiovisual transnacional chamado Parceria Entre Fronteiras. Conforme Rebelatto e Fonseca (2015, p. 14), essa experiência teria carregado "em suas marcas estéticas e modos de produção as discussões políticas e fundantes do fórum: a identidade cultural comum, as proximidades geográficas e as particularidades desses paços de fronteira, que na margem são portas de entrada de um lado e de outro de seus países". Foram produzidas obras audiovisuais como Causos e Contos de fronteira, Jesareko, Fronteira e Riberas.

O festival Oberá en Cortos foi destacado nas entrevistas realizadas em Misiones como um espaço de grande importância ao audiovisual regional. Conforme Monsu (2016), o festival promoveu uma cena audiovisual e fez avançar os vínculos entre diversas organizações da região. A partir dessa cena, foram amplificadas as demandas por ações de capacitação, exibição e fomento. As experiências do festival de Oberá e do Fórum Entre Fronteiras teriam fortalecido dinâmicas de produção e trabalho no audiovisual. Para além de um encontro de produtores, o evento buscava, também, pensar a política audiovisual e ações para integração dos agentes. Segundo entrevista de Marcelo Alejandro Rodríguez ${ }^{77}$, houve uma iniciativa de projeto de lei provincial de fomento ao audiovisual em 2005, a partir de demanda da rede de produtores audiovisuais, com orientação mais voltada ao cinema. Em 2007, houve um debate sobre a análise do projeto de Lei Provincial do Audiovisual no festival Oberá en Cortos, no espaço Entre Fronteiras (OBERÁ EN CORTOS, 2009). Este projeto não avançou no legislativo provincial.

77 Entrevista de Marcelo Alejandro Rodríguez ao autor, em novembro de 2016, em Posadas (Misiones). Rodríguez foi secretário geral do sindicato argentino de televisão, telecomunicações, serviços audiovisuais, interativos e de dados, deputado provincial (2011-2015) e, desde 2016, preside a empresa pública Marandú Comunicaciones. 
Os agentes participantes da cena audiovisual misioneira também fizeram parte das discussões sobre a Lei de Serviços de Comunicação Audiovisual nacional, em 2009, segundo as entrevistas realizadas. Na edição de 2009 do festival Oberá en Cortos, houve debates sobre o projeto de lei e sobre a digitalização da televisão (OBERÁ EN CORTOS, 2009). Posteriormente, com a informação de que haveria um programa de federalização do audiovisual, foi conformada uma comissão pró-polo audiovisual na região. Os agentes e redes presentes incidiram, ainda, na regionalização do programa - houve críticas às primeiras propostas de divisão regional, que englobavam a província de Entre Ríos no NEA, ao invés de integrá-la com Santa Fe (ZANOTTI, 2016).

A chegada do Programa Polos encontrou, portanto, uma trama de agentes e redes conformadas e uma situação geográfica propícia à participação conjunta de diferentes atores interessados em impulsionar a produção audiovisual no local. Após conformado o Polo NEA, foi designada a Universidade Nacional de Misiones (UNAM) como coordenadora do Polo e conformada a equipe, com apoio metodológico para o processo participativo. A escolha da UNAM como coordenadora deu-se devido ao desenvolvimento do audiovisual local e à proximidade de agentes de Misiones com a coordenação do Programa ${ }^{78}$. A reunião inaugural do Nó Misiones (1) reuniu 50 pessoas.

78 Entrevista de Hernán Cazzaniga ao autor, em novembro de 2016 em Posadas (Misiones). Cazzaniga, antropólogo e docente da UNAM, foi coordenador do Polo NEA e representante da UNAM na Rede Nacional Audiovisual Universitária (RENAU) e na Associação de Radiodifusoras de Universidades Nacionais Argentinas (ARUNA). 
Tabela 1: Participantes da primeira reunião do Nó Audiovisual Misiones

\begin{tabular}{|c|c|}
\hline Organização ou Instituição & Participantes \\
\hline Coordenação do Polo e equipe metodológica & 6 \\
\hline FecoopTv - Federación Cooperativa de Productores de Contenidos Audiovisuales & 2 \\
\hline Cooperativa de Trabajo La Rastrojera & 1 \\
\hline Cooperativa Luz y Fuerza de Ldor. Gral. San Martín (Canal 3) Pto. Rico & 1 \\
\hline Cooperativa de Trabajo de Graduados de la Facultad de Humanidades - UNAM & 2 \\
\hline Cooperativa Productora de la Tierra & 2 \\
\hline Red de Realizadores Audiovisuales de Misiones & 2 \\
\hline Foro Entre Fronteiras & 1 \\
\hline Coordenação do Festival Oberá en Cortos & 1 \\
\hline Misiones Software Libre (MISOL) & 2 \\
\hline $\begin{array}{l}\text { Sindicato Argentino de Televisão, Telecomunicações, Serviços audiovisuais, interativos e } \\
\text { de dados (SATSAID) }\end{array}$ & 1 \\
\hline Canal 12 Misiones - Multiedios SAPEN & 4 \\
\hline CCTV Canal 4 - Cooperativa Eléctrica de Eldorado Ltda. (CEEL) & 3 \\
\hline SGS Vallevisión SRL & 2 \\
\hline Escuela de Música de Posadas & 2 \\
\hline Estúdio De la Mente Records & 1 \\
\hline Toon'tas Animaciones Tarea Artística Solidaria & 1 \\
\hline UNAM - Reitoria & 1 \\
\hline UNAM - Faculdade de Humanidades e Ciências Sociais & 2 \\
\hline UNAM - Faculdade de Engenharia & 1 \\
\hline UNAM - Faculdade de Artes e Desenho & 2 \\
\hline Sistema Provincial de Teleducación y Desarrollo - SiPTeD & 3 \\
\hline Governo de Posadas & 1 \\
\hline Governo de Oberá & 2 \\
\hline Governo da Província de Misiones (Subsecretarias: Ciencia y Tecnología, Cultura) & 3 \\
\hline TVE-RS (Brasil) & 1 \\
\hline Total de participantes & 50 \\
\hline
\end{tabular}

Elaboração: André Pasti. Fonte: Nodo Audiovisual Misiones (2011a).

Observam-se 26 diferentes organizações na reunião inaugural, que envolviam cooperativas, redes de produtores, canais, estúdios, ONGs e distintas partes da universidade. Para a organização desse início do Nó, foi divulgada uma convocatória pública e foram mapeados os potenciais participantes para envio 
de convites, conforme entrevista ${ }^{79}$. Agentes ligados à comunicação comunitária ${ }^{80}$, pouco ou nada institucionalizados, relataram desconfiança com a convocatória, questionando a quem estava voltado o programa. As contradições fazem parte desse movimento dialético da configuração e institucionalização das redes, onde a potência dos espaços e redes já constituídos acompanha, por outro lado, uma situação onde agentes de fora dessas articulações podem ter menos expressão em um momento como a conformação de um espaço institucional participativo.

Além desse conjunto de participantes, se somaram na segunda reunião integrantes das seguintes organizações, cooperativas e comunidades: Comunidades Mbya Guaraní de Marangatú, 25 de Mayo e Puerto Libertad; Cooperativa Puerto Esperanza Canal 9; Revista Superficie; Associação de Designers; Wanda Cable Visión; Chefia de Assessores do Governador; Cable Puerto Iguazú; e Cooperativa Sinergia, e na terceira, a instituição privada de ensino Instituto Superior Antonio Ruiz de Montoya (NODO AUDIOVISUAL MISIONES, 2011b, c).

Para Lombardini (2016), a organização precedente criou um cenário propício ao desenvolvimento de um processo participativo de impulsionamento do audiovisual, enquanto o Programa Polos foi o responsável por potencializar, no lugar, essas condições. Outros entrevistados (MONSU, 2016; RODRÍGUEZ, 2016) apontaram esse fortalecimento da discussão sobre o audiovisual, das ações de capacitação e do fomento também como elementos centrais legados pelos PAT. Se antes o audiovisual ligado ao cinema já estava mais densamente organizado, o programa Polos reuniu estes com outros agentes, como cooperativas, universidades, sindicatos e canais ligados à produção e circulação de informações para televisão.

79 Entrevista de Mariana Lombardini ao autor, em novembro de 2016 em Posadas (Misiones). Lombardini é comunicadora, foi assessora metodológica e de gestão do Polo NEA e em 2016 passou a dirigir a área de Pesquisa e Capacitação do IAAVIM, além de ser docente na UNAM.

80 Entrevista de Nico Amadio e Alex Streuli ao autor, em novembro de 2016 em Posadas (Misiones). Ambos são comunicadores da cooperativa de comunicação comunitária La Rastrojera, integrante da Red Nacional de Medios Alternativos. 
A metodologia de participação popular do programa, de gestão associada (POGGIESE, 2011), possibilitava, segundo Lombardini (2016), que os encontros fossem produtivos e houvesse o avanço das questões propostas pelos agentes do Nó Audiovisual. Esse processo participativo é repleto de potências e contradições. De um lado, ele amplifica as vozes dos distintos grupos e agentes locais - ampliando a densidade comunicacional do lugar. Lombardini destacou, ainda, o fato de que o Estado tenha executado uma política pública nesses termos e, conforme seu relato, "de repente, poder estar em um espaço onde se discutia e que nos propunha a possibilidade de pensar e dizer como nós imaginávamos que devia ser a implementação da televisão" (LOMBARDINI, 2016, tradução própria). Esse processo possibilitava o encontro da diversa trama existente no lugar e potencializava as relações e vínculos regionais (MONSU, 2016). Por outro, encontrava um conjunto de contradições e barreiras em relação à cultura de participação em um contexto global de competitividade e individualismo da razão neoliberal, que acompanha demandas das mais diversas - nas entrevistas, além da falta de cultura de participação em alguns lugares houve relatos de quem questionava os ganhos do processo, e de desinteresse daqueles que "só queriam produzir".

Segundo o coordenador do Polo NEA, parte das deliberações de organização do programa, referentes a temas como direitos, fomento e pagamentos foram sendo tomadas ao passo que as ações se desenvolviam - o que revelaria, para ele, um caráter performativo do Programa, de descobrir as práticas no processo (CAZZANIGA, 2016). Isso teria causado algumas tensões com as distintas situações das Universidades, que teriam uma cultura administrativa menos flexível.

Ao longo das reuniões, o Nó Misiones foi construindo sua agenda de debates ligada às demandas do lugar e respondendo, a partir do lugar, às linhas de fomento e ação do programa nacionalmente. Inicialmente, o Nó participou do Plano Piloto, que buscava o "teste das capacidades" produtivas dos lugares. Em 
diversas entrevistas, apareceu um desconforto com esse "teste" devido às relações construídas e reproduzidas da desigualdade regional (expresso, por exemplo, na fala “Novamente, Buenos Aires é que vai testar nossa capacidade?"). Agentes bastantes diversos participaram desse plano piloto, de múltiplas ações de capacitação e das linhas de produção iniciais.

O Nó Audiovisual Misiones também recebeu um Centro Público de Produção Audiovisual (CEPA). O CEPA reúne equipamentos que viabilizam a produção televisiva com significativa qualidade técnica. De acordo com relatos das entrevistas realizadas, distintos agentes do Nó disputaram a localização do CEPA, entre Posadas e Oberá. Por fim, ele foi localizado em Oberá, abrigado na Faculdade de Artes e Desenho da UNAM. Além do CEPA, houve o financiamento de equipamentos para gravação na qualidade necessária para a televisão digital, beneficiando grupos de comunicação comunitária.

As produções audiovisuais da Fábrica de TV, que posteriormente foram veiculadas em canais da província, foram duas: Casi el mismo techo e Revolución en Estéreo. A ficção Casi el mismo techo é uma comédia a cargo da Productora de la Tierra, contando uma história envolvendo habitantes de um pequeno bairro próximo da tríplice fronteira Argentina-Paraguai-Brasil, apresentando situações características da região. A 21 ilustra algumas das cenas do programa. O elenco era de Misiones e a equipe técnica da região. 
Figura 21: Cenas da produção Casi un mismo techo - Nó Audiovisual Misiones

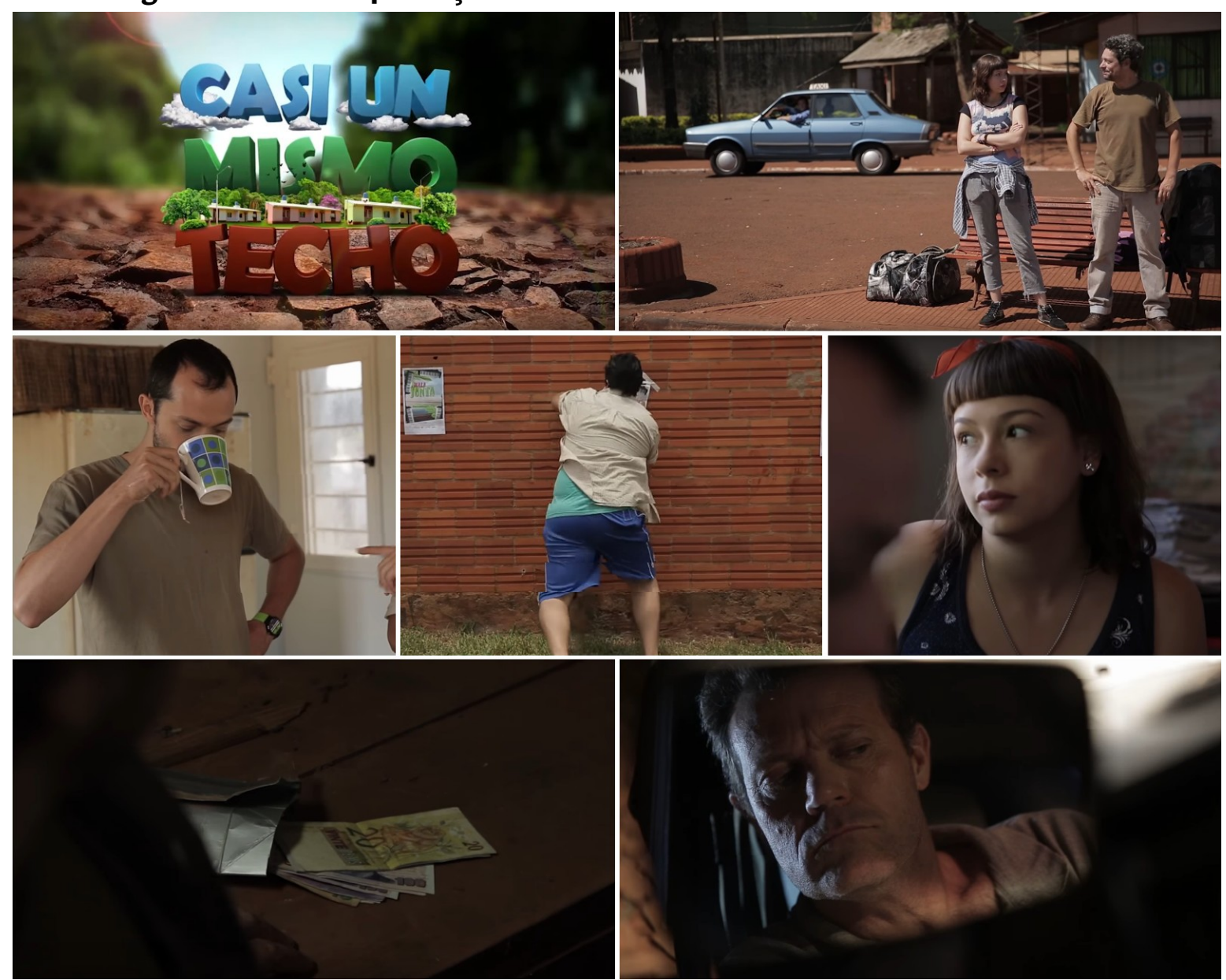

Montagem elaborada por André Pasti. Fonte: Acervo do Programa.

O outro programa, o musical Revolución en Estéreo, é da cooperativa de comunicação comunitária La Rastrojera TV, feito em parceria com outros agentes da comunicação comunitária local e com o estúdio local De la Mente Records. Este ciclo televisivo buscou trazer músicos e bandas de diferentes lugares da província de Misiones, como ilustrado nas cenas selecionadas (22).

Ambos os programas mobilizaram pessoas da região para os trabalhos envolvidos nas diversas etapas da produção audiovisual, além de buscar expor temas ligados ao cotidiano do lugar. 
Figura 22: Cenas do programa Revolución en Estereo - Nó Audiovisual Misiones

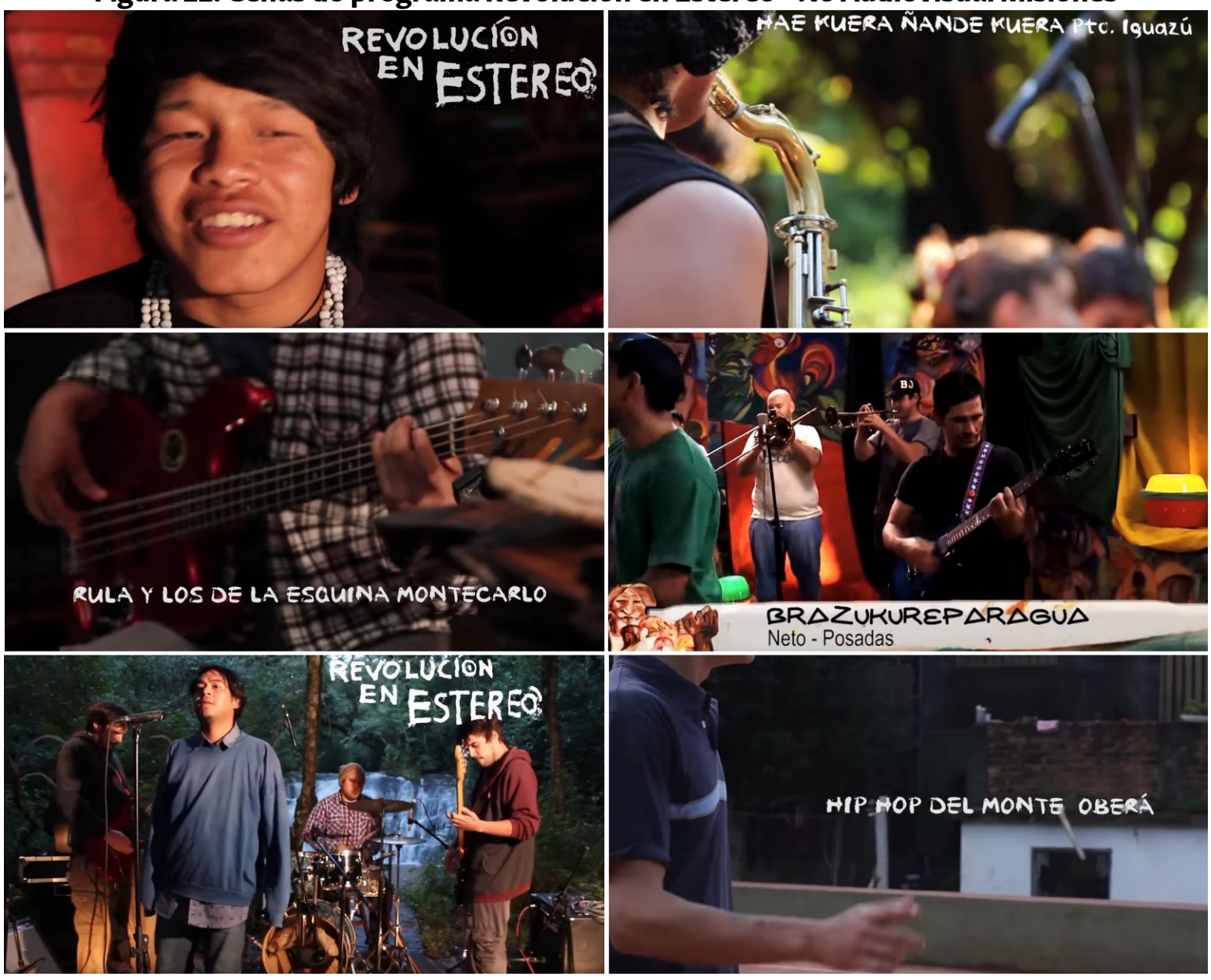

Montagem elaborada por André Pasti. Fonte: Acervo do Programa.

Cabe considerar que se trata de um lugar de fronteira, como aponta Benedetti (2014, p. 57), marcado pela convivência com o vizinho do outro país e por elementos da dinâmica transfronteiriça, como a circulação de mercadorias e a presença das autoridades aduaneiras em seu cotidiano. Para o autor, nessas localidades, “o sentido de lugar está de alguma forma atravessado por sua posição de fronteira e pela imediatez do outro nacional, que influencia na organização dos tempos e espaços cotidianos" (BENEDETTI, 2014, p. 57, tradução nossa). Na comunicação, essa questão é evidente pela presença da radiodifusão dos países da fronteira, onde há consumo audiovisual de ambos os lados (BRANDALISE, 2011), e pela importância do portunhol ${ }^{81}$ no cotidiano do lugar.

81 Analisando com ênfase a fronteira Brasil-Uruguai, Sturza (2004) define o portunhol como "o resultado da
mistura das línguas portuguesa e espanhola utilizada de modo geral pelos habitantes, principalmente da zona 
Além das produções em si, as reuniões do Nó foram marcadas pelo debate sobre políticas públicas audiovisuais. Na ata da quarta reunião, aparece como um dos consensos do grupo a definição dos grupos de trabalho entre as seguintes temáticas: capacitação; fórum de políticas públicas audiovisuais da província de Misiones; e produção de conteúdos.

O debate sobre a necessidade de políticas de fomento a um polo audiovisual regional mais permanentes esteve presente nas plenárias do Nó Misiones. Essas plenárias possibilitaram, para Lombardini (2016), fortalecer as relações entre os agentes e pensar planos estratégicos a nível regional. Anteriormente, já havia uma demanda de lei de fomento para o cinema, que não havia avançado. $O$ encontro de agentes ligados ao cinema com aqueles ligados ao audiovisual para televisão, cooperativas, instituições de comunicação comunitária e até integrantes do parlamento local nos Nós potencializou o debate de uma política de Estado provincial para a comunicação.

Como frutos do trabalho do Nó Misiones, foram realizados quatro Fóruns de Políticas Públicas Audiovisuais de Misiones. Na divulgação da primeira edição do evento (23), realizada em maio de 2012, a questão do desenvolvimento da indústria audiovisual regional tinha destaque.

fronteiriça”. Sobre a região de Misiones, a autora afirma que "muitos dos habitantes das zonas mais limítrofes, na região de Misiones, têm apresentado dificuldades de aprender o espanhol standard, pela forte presença na sua fala de um dialeto" chamado de Híbrido Fronterizo ou portunhol (STURZA, 2004, p. 157). 
Figura 23: Divulgação do I Fórum de Políticas Públicas Audiovisuais de Misiones

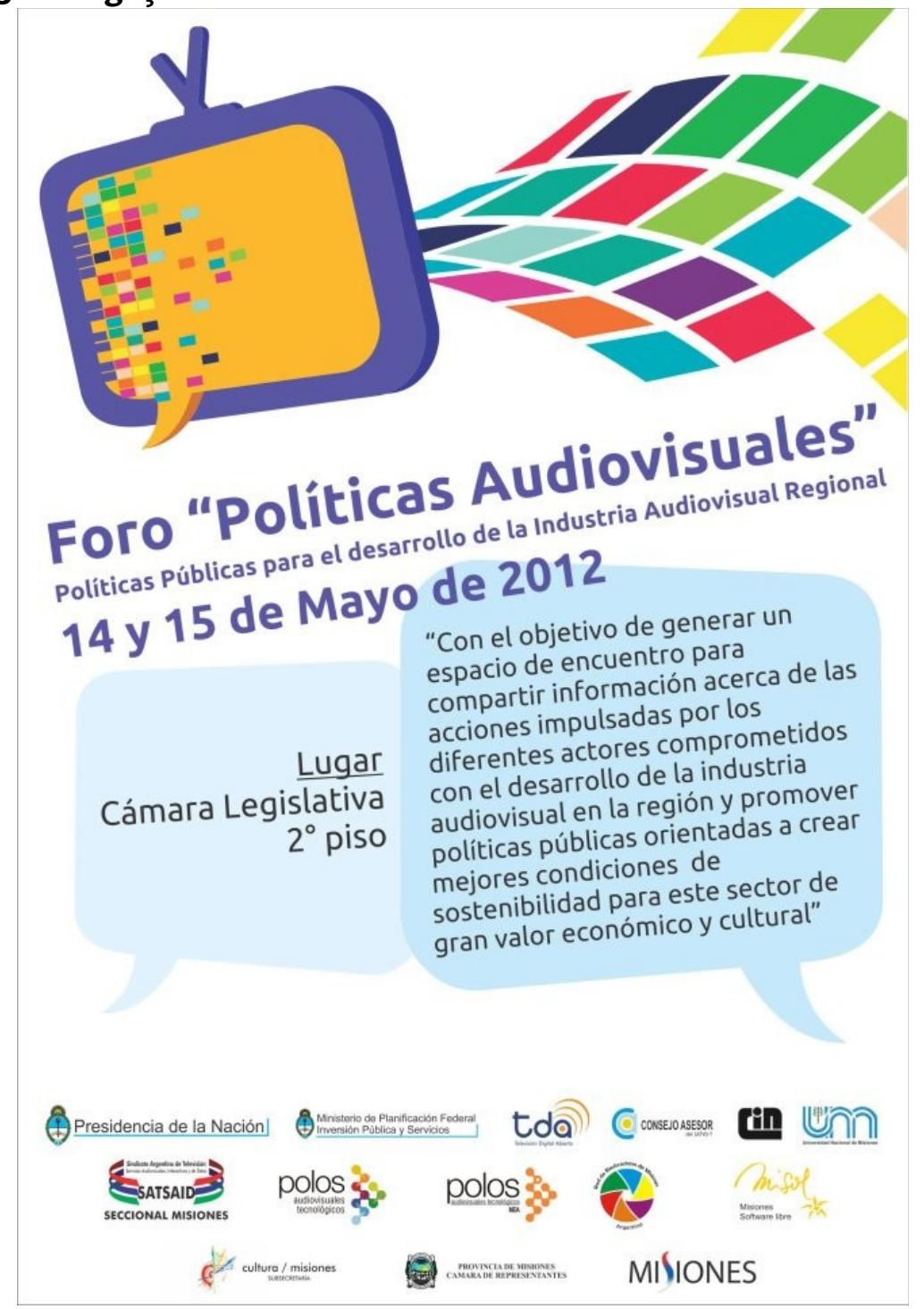

Fonte: Acervo do Programa.

Conforme Cazzaniga (2016), na primeira edição do Fórum, houve diversos convidados de outras partes do país, pois se buscava validar a agenda regional. Nessa primeira edição, foram formulados os principais consensos sobre uma legislação que viesse a potencializar o audiovisual da província. Na segunda edição do Fórum, em agosto de 2013, o destaque já foi o debate dos artigos de um projeto de Lei de Promoção Audiovisual de Misiones, incorporando as demandas apresentadas pelo Nó Audiovisual. Houve, ao longo dos anos, diversos encontros pré-Fórum para construir, coletivamente, a agenda de discussão. 
Conforme entrevistas (CAZZANIGA, 2016; MONSU, 2016), a aproximação dos agentes no Nó Misiones encontrou uma conjuntura particularmente potente: um dos integrantes do Nó, Marcelo Rodríguez, que representava o sindicato ligado à televisão, foi eleito deputado provincial. Com bom trânsito no legislativo, Rodríguez conseguiu encaminhar o projeto conforme apresentado pelos agentes da comunicação organizados no Nó Misiones (ZANOTTI, 2016). Segundo Rodríguez, em entrevista, a lei foi resultado do programa Polos, que permitiu que os diversos agentes se reunissem, trocassem experiências, impulsionou o trabalho conjunto e possibilitou que se construísse um consenso ativo sobre a política pública para a comunicação audiovisual provincial. A aprovação da lei VI n. 171 de Promoción Audiovisual de Misiones precedeu o terceiro Fórum de Políticas Públicas Audiovisuais, em maio de 2014. Seu primeiro artigo afirma que:

\begin{abstract}
A presente Lei apoia, promove e fomenta a criação e produção de obras audiovisuais, sua difusão e conservação como patrimônio sociocultural, priorizando a valorização das identidades regionais, a diversidade cultural e a liberdade de expressão artística, assim como a pesquisa, experimentação, formação e aperfeiçoamento de recursos humanos associados a eles. Entendendo que toda obra audiovisual tem um valor simbólico fundamental para a sociedade, a presente Lei constitui-se como uma ferramenta para estabelecer estratégias e políticas com o objetivo de desenvolver e fortalecer os diferentes setores governamentais, não-governamentais e privados, com ou sem fins lucrativos, implicados na produção audiovisual, a fim de alcançar uma rede de produção, exibição e circulação audiovisual economicamente sustentável, socialmente justa e tecnicamente viável (MISIONES, 2014, tradução nossa).
\end{abstract}

A lei previa a criação de uma autarquia, o Instituto de Artes Audiovisuais de Misiones (IAAVIM), para a aplicação da lei. O IAAVIM deveria ser coordenado por alguém indicado pelo Poder Executivo, mas com a exigência legal de que fosse ligado ao audiovisual da província, com ao menos cinco anos de atividade audiovisual na província e com residência de ao menos cinco anos 
em Misiones. O Conselho Diretor do Instituto teria, ainda, um representante da Universidade de Misiones, um representante das entidades sindicais dos trabalhadores do audiovisual e um representante audiovisual para cada uma de quatro regiões da província (MISIONES, 2014). A regionalização da província para o audiovisual foi uma ação inspirada pelo Programa Polos (RODRÍGUEZ, 2016), assim como o impulsionamento de um processo participativo para sua gestão e a aplicação da metodologia participativa em várias das ações do Instituto (LOMBARDINI, 2016).

Houve dificuldade na definição das regiões na proposta da lei pela sociedade civil organizada, conforme relato de Zanotti (2016), que considera que deveria haver mais pesquisas sobre o tema. Buscava-se uma regionalização capaz de refletir a cultura e facilitar a participação. Por fim, decidiu-se pela proposta de seguir a regionalização eleitoral da província. O IAAVIM hoje atua com a regionalização em quatro distritos: (1) Distrito Norte: departamentos de Iguazú, General Manuel Belgrano, Eldorado e San Pedro; (2) Distrito Paraná: Libertador Gral. San Martín, Montecarlo e San Ignacio e os municípios Cerro Corá, Loreto, Mártires, Profundidad e Santa Ana do Departamento Candelaria; (3) Distrito Uruguay: Oberá, Leandro N. Alem, Guaraní e Cainguás; e (4) Distrito Sur: Capital, Apóstoles, Concepción de la Sierra e o município de Candelaria.

A aprovação da lei não encerrou os debates de políticas públicas audiovisuais iniciados pelo Nó. Houve uma quarta edição do Fórum, em maio de 2015. A regulamentação da lei se deu no mesmo mês e a implantação da criação do IAAVIM ocorreu em dezembro de 2015, com seu funcionamento iniciado em 2016. Axel Monsu, integrante do Nó Misiones, produtor audiovisual e organizador do festival Oberá en Cortos foi indicado para coordenar a instituição.

Em seu repertório de ações, o IAAVIM conta com nove programas: (1) Siembra Audiovisual Misiones, para trabalho interinstitucional conjunto com múltiplos agentes da sociedade para o desenvolvimento de políticas audiovisuais; (2) Gestión Audiovisual Territorial, com processo participativo para 
aproximar agentes das ações audiovisuais; (3) Incubadora Audiovisual de Misiones, para dar assistência técnica e artística para desenvolver projetos audiovisuais; (4) Alfabetização audiovisual, voltado a escolas e à comunidade em geral; (5) Circuito de Pantallas, programa para a circulação de audiovisual na província em múltiplas janelas de exibição - salas de cinema, cineclubes, cinema móvel, TV a bordo e outras; (6) Conservação e valorização do patrimônio audiovisual; (7) Assistência financeira e captação de investimentos; (8) Promoción Destino Misiones y Logística Territorial, voltado a criar condições adequadas para produções que querem usar a província como set de filmagem; e (9) Capacitação técnica profissional, pesquisa e vínculo com estúdios (IAAVIM, 2017). É possível observar a influência das práticas do Programa Polos em vários dos programas do Instituto. Conforme Lombardini (2016), muitas das ações do IAAVIM vieram das demandas surgidas do Nó Misiones.

Após a institucionalização do IAAVIM, os Fóruns seguiram ocorrendo. Nos debates realizados, foram colocados os desafios para expandir o processo de avanço do audiovisual de forma participativa de Misiones para o restante da região do nordeste argentino.

\subsubsection{Avanços, limites e aprendizados da experiência do Programa Polos}

A experiência do Programa Polos Audiovisuais durou menos de cinco anos. Ainda que breve, essa política permite algumas considerações sobre os avanços, limites e aprendizados legados - entendendo as resistências de diversas ordens a uma transformação radical da organização da comunicação no território em um curto período. Como afirma Iturralde (2015, p. 174, tradução nossa),

Nos últimos anos, tem sido geradas diferentes rupturas com o sistema tradicional de meios de comunicação na Argentina. Essas transformações se traduzem em novos marcos normativos e na implementação de políticas públicas concebidas para promover a descentralização tanto na tomada de decisões como no acesso e na participação. Todavia, estas mudanças não geram transformações de um dia para o outro, mas marcam o início de 
processos que precisam ser sustentados ao longo de tempo e que envolvem importantes mudanças culturais.

Cabe identificar alguns dos pressupostos principais do programa Polos enquanto experiência de formulação de política de comunicação voltada à criação de condições para a descentralização da produção de informações no território argentino. O primeiro deles é o papel ativo do Estado para essa descentralização, por meio do financiamento, da capacitação, da montagem de estúdios equipados, em busca da criação de condições técnicas, de organização e financeiras para desenvolver - no médio e longo prazo - a produção audiovisual nos lugares menos centrais.

Na questão financeira, o Programa Polos também tinha em sua concepção a necessidade de buscar financiamentos que garantissem, ao longo do tempo, alternativas para que as produções se sustentassem economicamente que não implicavam na retirada do Estado do Programa. Em sua linha de pesquisa, o PAT desenvolveu amplos estudos sobre o financiamento dos meios na Argentina e questões do mercado audiovisual, para subsidiar essas políticas (ARGENTINA, 2013b, a).

Outro pressuposto foi a necessidade de pensar novos formatos para o audiovisual. Este estava baseado no entendimento de que as alternativas à mídia concentrada não passam por uma imitação de suas práticas, como afirma Suárez (1996, p. 51, tradução nossa):

A desigualdade criada pelos recursos materiais consolidados é imensa. Mas o maior erro seria imitar os grandes meios de comunicação com a pretensão, vã, de ser como eles ou de substituí-los. [...] É necessário criar redes de meios alternativos que combinem esforços e que permitam obter vantagens recíprocas dos resultados de cada um.

Nesse sentido, um elemento marcante da proposta de organização do programa - e a base para todo o seu funcionamento - foi a composição da rede federal de Nós Audiovisuais, organizados a partir da articulação dos agentes 
ligados ao audiovisual ou interessados nele, em processos participativos. Por fim, destaca-se a perspectiva de promover o desenvolvimento regional dos polos audiovisuais com a articulação dessa rede, baseada, sobretudo, em cidades médias do interior do país.

Entre as dificuldades apontadas por parte da equipe técnica e de pesquisa do programa para uma maior expressividade dos resultados do Programa estão o pouco tempo de desenvolvimento do programa, as dificuldades para a ampliação do acesso à Televisão Digital - onde a falta de canais foi apontada como um elemento importante - e avanços necessários no debate das programações. A principal delas foi a dificuldade de financiamento a partir da ampliação dos efeitos da crise financeira na Argentina (BERNARDO; GIBEAUD; ELEM, 2016). Nessa questão do financiamento, as entrevistas apontaram diversos elementos complicadores: a crise financeira do Estado argentino, outras prioridades do Estado na agenda da comunicação, as prioridades do CIN diante de seus convênios com o Estado - dos quais o Programa Polos era apenas um -, dificuldades operacionais e atrasos para pagamentos acordados, entre outros. Fato é que, em meio ao programa, os recursos diminuíram - coordenadores dos Polos, como no caso do NEA, reduziram o ritmo das atividades para aguardar encaminhamentos (CAZZANIGA, 2016).

O eixo de pesquisas do Programa gerou análises de contribuições para o desenvolvimento da TV digital que abarcaram a questão da sustentabilidade econômica desses mercados audiovisuais - pensando os polos e produções regionalizadas em suas possibilidades de inserção e promoção de um mercado audiovisual viável nos lugares. Para tanto, foram identificadas dez áreas ${ }^{82}$ que

82 A pesquisa propôs a identificação de Áreas Geográficas Audiovisuais (AGAs). Estas seriam “mercados locais/regionais de produção e consumo audiovisual", que "podem englobar mais de uma localidade e podem incluir mais de um Nó Audiovisual. A ideia de AGA tenta responder ao que são, ou podem ser, os mercados audiovisuais reais" (ARGENTINA, 2013b, p. 14, tradução nossa). Foram identificadas 10 AGAs, com base em critérios como tamanho da população, existência de Nós Audiovisuais, viabilidade da pesquisa e uma mostra diversa: Conurbano Sudeste e Conurbano Noroeste (Polo Metropolitano); Gran Córdoba e Villa María (Centro); Comodoro-Caleta Olivia (Patagônia Sul); Mar del Plata (Província de Buenos Aires); Gran Santa Fe-Paraná 
compõem os Polos para a análise. Entre as conclusões do estudo (ARGENTINA, 2013b), considerando as características dos mercados locais e da televisão nessas áreas e o Programa Polos, destacam-se: (1) a predominância de formatos de programas de estúdio, de baixo custo nos canais locais; (2) a fraca experiência em formatos alternativos, com pouca capacidade de estimar os custos das produções - o que alimenta a venda ou aluguel de horários, com responsabilização dos pequenos produtores pela viabilidade econômica; (3) o desafio de realizar coproduções entre os agentes locais e os canais locais - o que também foi apontado por José Borello ${ }^{83}$ em entrevista; (4) a dependência dos recursos publicitários e a concentração publicitária, ainda que canais locais busquem outras formas de financiamento; (5) além da desigualdade capitalinterior, há grande desigualdade entre as diversas regiões, com situação privilegiada nos centros mais importantes (os nós da rede urbana em posição hierárquica superior); (6) não parecia haver muitas relações interior-interior no mercado audiovisual - os principais vínculos comerciais dos canais locais eram com meios de Buenos Aires; e (7) entrevistados apontaram a necessidade de seguir com as articulações entre os agentes para além dos espaços propiciados pelas políticas nacionais (em especial o Programa Polos).

Um grande desafio apontado nas entrevistas foi a questão das janelas de exibição - especialmente os canais televisivos. A dificuldade de efetivar a ampliação das janelas de exibição na curta vigência da LSCA significou, para as produções financiadas pelo Estado na TDA e em especial no Programa Polos, uma limitação a sua circulação. Essa questão se articula com outra, também tratada nas entrevistas: a questão dos direitos sobre as produções audiovisuais, já mencionada no capítulo anterior. Albornoz e Cañedo (2016, p. 193) explicam que

por um lado, os direitos de propriedade intelectual e industrial das produções

(Centro-Este); Gran Mendoza (Cuyo); Posadas (NEA); e Gran San Salvador de Jujuy (NOA).

83 Entrevista de José Borello ao autor, em novembro de 2016, em Buenos Aires. Borello é professor da Universidad Nacional de General Sarmiento (UNGS), em Los Polvorines. Suas pesquisas tratam sobre a geografia econômica da produção e consumo de cinema e audiovisual, e ele atuou como pesquisador do PAT. 
pertencem ao Estado e estes deveriam ser integrados no catálogo BACUA com a intenção de atrair potenciais canais/sinais. Por outro lado, os direitos dos formatos das produções pertencem aos seus criadores, os quais têm o direito de comercializá-los no interior e exterior do país.

A circulação das obras foi um empecilho para a visibilidade do PAT para além das organizações participantes, da comunidade audiovisual, dos lugares onde as produções foram veiculadas e dos consumos por meio das plataformas como BACUA e CDA. Albornoz e Cañedo propõem que políticas com esses fins devem "definir cuidadosamente os responsáveis em comercializar os programas realizados e seu modus operandi, e estabelecer uma estratégia que inclua a difusão de conteúdos através de plataformas online" (ALBORNOZ; CAÑEDO, 2016, p. 198, tradução nossa).

O processo de implantação dessa e de outras políticas encontra uma diversidade de conflitos, contradições e tensões internas aos agentes que conduzem o programa. No caso do PAT, destacaram-se as tensões geradas no âmbito da gestão compartilhada, onde o CIN - representando as Universidades gerenciava os recursos, mas a coordenação geral do Programa era realizada por equipe do Conselho Assessor da TDA. Foram diversas as tensões, em torno de temas como a escolha das Universidades que seriam as coordenadoras dos Polos, a gestão de recursos, a instalação e o regramento dos CEPAs, entre outras questões. Havia diferenças de concepção, pois as Universidades coordenavam os Polos e os recursos financeiros e vislumbravam, com o Programa Polos, a possibilidade de produzir conteúdos à rede universitária e equipar e fortalecer o audiovisual universitário já existente - na rede RENAU ${ }^{84}$. Já a coordenação do Programa pela TDA apostava em processos que não ficassem centralizados pelas Universidades (PIWOWARSKI, 2016), capitaneados pela comunidade audiovisual externa às instituições universitárias. Um contra-argumento apresentado nessa tensão era de que, em muitos lugares, a Universidade estava bastante integrada à

84 Entrevista de Claudia Ducatenzeiler ao autor, em dezembro de 2016, em Buenos Aires. Ducatenzeiler era coordenadora geral da unidade de gestão de projetos de comunicação audiovisual do CIN, coordenando a RENAU (Rede Nacional Audiovisual Universitária). 
comunidade cultural local - como afirmado em entrevistas do Nó Conurbano Sudeste ${ }^{85}$.

Vários relatos trataram sobre essas tensões que, em muitos momentos, teriam amortecido o avanço do PAT. Os CEPAs são um exemplo de como essa tensão acabou não permitindo o estabelecimento de um regulamento de funcionamento dos centros públicos, que acabaram, ao fim do programa, incorporados pelas Universidades onde foram instalados. Os conflitos dos CEPAs, segundo as entrevistas, envolviam desde os usos permitidos e a localização até a disputa de quem seria responsável por manter funcionários para que o centro estivesse aberto.

Um dos resultados do Programa após seu encerramento está ligado, justamente, ao fortalecimento da comunicação audiovisual universitária, que passa pela capacitação de pessoal, consolidação de CEPAs e incorporação de quadros técnicos a universidades. A coordenadora da rede audiovisual universitária apontou o programa como um dos instrumentos para garantir a aplicação dos princípios da LSCA (DUCATENZEILER, 2016), que também tinha outros instrumentos para fortalecer o audiovisual a partir do sistema universitário federal argentino. A RENAU contava, em 2018, com 20 canais ligados a diferentes universidades (CIN, 2018).

$\mathrm{O}$ aspecto mais destacado do programa em diversas entrevistas foi a possibilidade de promover uma trama ativa de agentes ligados à comunicação, potencializando processos coletivos de produção, trocas e experiências de trabalho conjunto, avançando nos processos e ligações já existentes e ampliando as condições de organização para a promoção do audiovisual nos lugares. No

85 Entrevistas com Gabriel Wainstein, Daniel Symcha, Luis Rivero e Axel Ribeiro, em dezembro de 2016, em Florencio Varela (Província de Buenos Aires). Todos integram a equipe de comunicação da Universidad Nacional Arturo Jauretche (UNAJ). Wainstein integra a Associação de Radiodifusoras de Universidades Nacionais Argentinas (ARUNA) e foi co-coordenador do Programa Polos na região sul da Grande Buenos Aires (Nó Conurbano Sudeste). Symcha é jornalista e artista audiovisual, cofundador e secretário da Asociación de Artistas Visuales Independientes de Florencio Varela, e trabalha na Rádio UNAJ. Rivero, diretor da Rádio UNAJ, acompanhou a trajetória do Nó Conurbano Sudeste. Ribeiro é camarógrafo, participou do Programa Polos e hoje trabalha na equipe de comunicação da UNAJ. 
caso do Nó Misiones, isso ficou evidente - ali, além dessa potência, foi possível levar para a produção audiovisual para televisão avanços organizativos que estavam sendo realizados para o cinema.

A avaliação do funcionamento desejado de um Nó Audiovisual, não se resume ao envolvimento nas produções audiovisuais propostas pelo Programa, mas na efetividade do processo participativo e do impulsionamento do audiovisual no lugar a partir da articulação dos agentes locais (Mapa 8).

\section{Mapa 8: Desenvolvimento dos Nós Audiovisuais - Programa Polos Audiovisuais Tecnológicos (2014)}

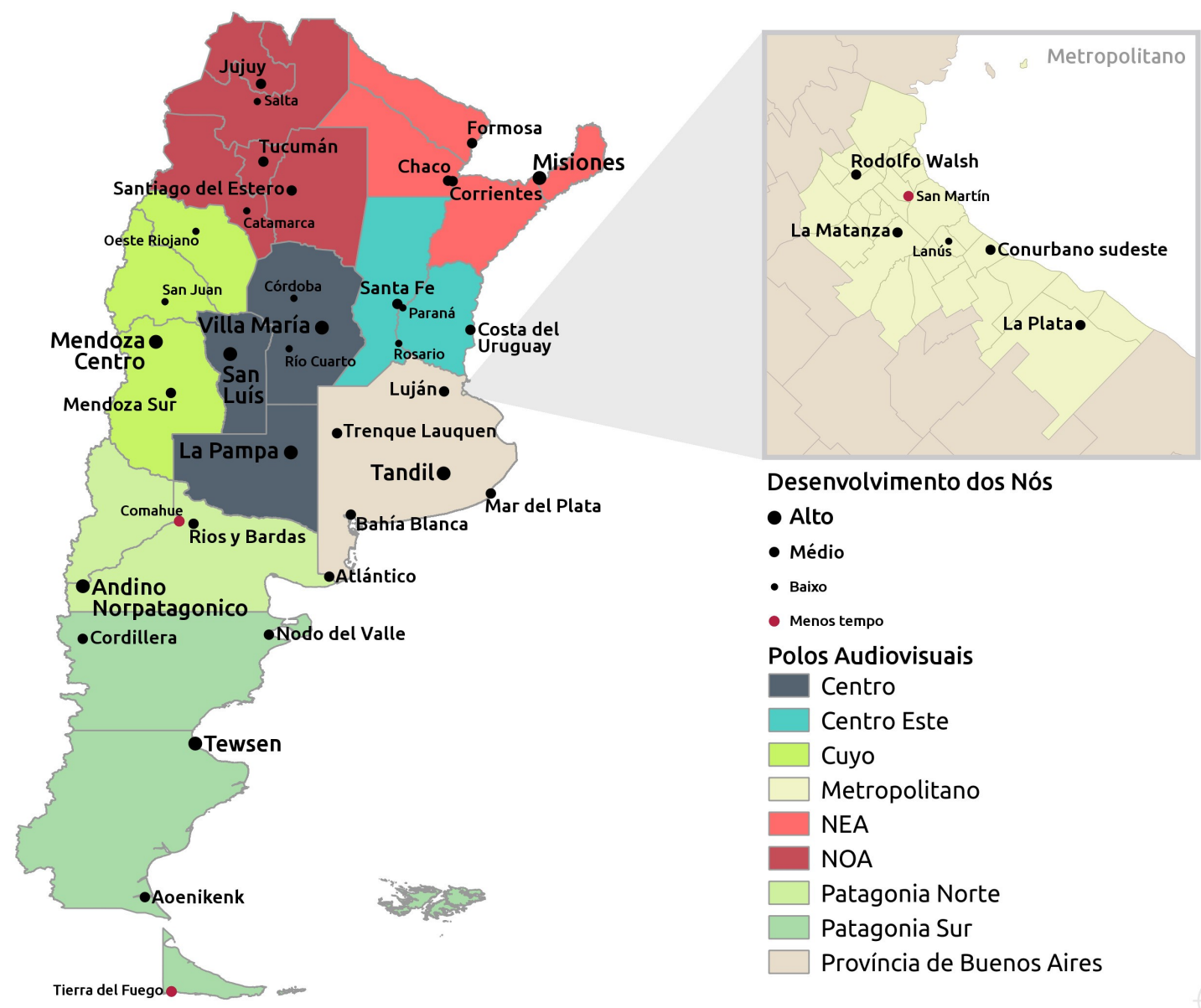

Elaboração: André Pasti. Desenvolvido com os softwares livres QGIS e GIMP. Fonte: entrevistas com equipe e acervo do programa.

O Mapa 8 mostra alguns dos Nós destacados nesse processo, a partir 
de avaliações da equipe coordenadora do Programa. Como é possível observar, a efetividade dos Nós conheceu um desenvolvimento desigual - os Nós de Misiones, Villa María, Tandil, San Luís, La Pampa, Andino Norpatagonico, Tewsen e Mendonza Centro se destacam. Sel (2013, p. 143) nota que, ainda que os projetos tenham contado com apoio técnico e oficinas de capacitação por parte de profissionais especializados em diversas áreas, o nível da produção é desigual, dadas as particularidades das instituições e empresas de cada Nó. Entre as razões apontadas em entrevistas para essas desigualdades estão a grande diversidade das condições técnicas, financeiras, normativas e de organização preexistentes. No entanto, também houve a avaliação de que em algumas cidades maiores, com Universidades mais centrais coordenando o programa, as atividades ficaram mais endógenas à comunidade universitária, sem potencializar os processos com agentes externos - o que significava que a proposta de Nós Audiovisuais não tinha encontrado o progresso desejado. As condições de organização envolviam as situações existentes nas Universidades houve relatos de tensões institucionais e pessoais em algumas províncias, onde reitorias controladas por pessoas politicamente críticas ao governo nacional e à LSCA não levaram o programa a frente, além de outras em que pessoas sem conhecimento ou interesse no audiovisual foram nomeadas à tarefa.

Um ponto destacado positivamente foi a metodologia participativa utilizada, de gestão associada entre sociedade Estado, buscando construir consensos ativos a partir da reunião de agentes diversos da comunidade. A metodologia que organizou o funcionamento dos Nós permitiu o avanço processual, o encaminhamento prático de questões levantadas e o registro da experiência. Na proposta metodológica, a institucionalidade do planejamento deve ser construída por acordo entre os participantes (POGGIESE, 2011), o que foi realizado no PAT. Cabe registrar que a proposta é fruto, também, de um acúmulo de experiências de outros processos participativos - conforme Poggiese (2009, p. 141), que envolvem práticas de educação popular e ambiental das décadas de 1970 
e 1980 e posteriores experiências de planejamento democrático. Segundo Lombardini (2016), a metodologia permitiu que os processos participativos fossem significativos - evitando plenárias longas e inócuas que, por vezes, marcam tentativas de participação pouco ou mal planejadas. Entre as barreiras a esse processo participativo, foi apontada a ausência de uma "cultura de participação" em certos lugares. Essa ausência é dominante na razão neoliberal (DARDOT; LAVAL, 2016), mas se expressa com maior intensidade em algumas situações. Há, ainda, relatos de que houve, inicialmente, algumas resistências à metodologia no momento em que foi proposta, não em função da proposta de trabalho, mas da origem - a faculdade FLACSO-Argentina, criando relutância em algumas das universidades públicas participantes do Programa.

A potência desse processo é notável na situação geográfica aqui analisada, do Nó Misiones: os Nós potencializaram os processos do lugar e levaram, além da reunião dos agentes, das produções e dos fóruns de discussão sobre comunicação, à aprovação de uma lei provincial de incentivo à comunicação audiovisual e à institucionalização de um projeto baseado no programa Polos, o IAAVIM. Resultado do programa, o IAAVIM tem, na maioria de suas linhas de ação, referências às práticas ou pautas levantadas no PAT.

É possível compreender, assim, o processo de efetivação dos Nós Audiovisuais como a potencialização da densidade comunicacional dos lugares, por criar condições técnicas, normativas, financeiras e de organização para o avanço da comunicação baseada nos cotidianos locais. Ainda que em um programa promovido a partir do Estado nacional, o processo participativo envolvido possibilitou ampliar as trocas efetivas entre os sentidos, projetos e anseios dos agentes dos lugares.

Com todos os desafios abertos, o Programa Polos é uma experiência importante que, em conjunto com as outras medidas então em curso para a democratização da comunicação no território argentino, buscou ampliar a produção de informações a partir dos espaços opacos - ou "silenciosos" - da 
globalização. Sua efetividade não pode ser medida apenas nos termos do alcance dessas informações, mas em relação ao processo e os pressupostos que o fundamentam, que podem contribuir para o avanço da regionalização da produção audiovisual, seja em uma reedição do Programa ou em futuros projetos com essa pretensão. 


\subsection{Condições para o audiovisual sem fins lucrativos nos espaços opacos da globalização}

Dar sentido à técnica, subordinando-a à ação conduzida por valores, tornou-se atualmente um extraordinário desafio. As forças que conseguirem fazer este movimento, isto é, produzir a mutação do automatismo em sentido, disputarão o poder que emana (e sustenta) o novo sistema social, cujos contornos atualmente apenas se vislumbram.

Ana Clara Torres Ribeiro. A natureza do poder: técnica e ação social (2000).

A apropriação das possibilidades de ampliação da densidade comunicacional dos lugares passa pelos meios de comunicação com vínculo ativo às dinâmicas locais. Essa agenda, além do objetivo de vocalizar agentes sociais, trata, também, da possibilidade de narrar o lugar e produzir sentidos vinculados ao cotidiano ali compartilhado. Como afirma Serpa (SERPA, 2011, p. 24),

apropriar-se - taticamente - dos meios de comunicação em uma escala local significa, para os grupos e iniciativas envolvidos nesses processos, enunciar um lugar a partir da ação e do discurso, "fabricando" lugares nas mais diversas escalas espaciais, para a reprodução de novas ideias de cultura a partir da criatividade e da subversão [...]

Essas outras possibilidades de narrar o lugar passam pelo entendimento da comunicação não como mercadoria, mas como direito. Assim, além das políticas de regionalização a partir do PAT, cabe investigar o conjunto de ações que articula a comunicação dos agentes sem fins lucrativos com outras lógicas de comunicação que não as ligadas ao mercado audiovisual.

Nesse sentido, são investigadas, aqui, as ações que acompanham o evento geográfico LSCA voltadas à comunicação alternativa, comunitária e popular, bem como as tensões, contradições e conflitos para a efetivação dessas ações. Outra dimensão desse entendimento da comunicação como um direito trata dos meios públicos. Brevemente, abordamos a experiência de um canal público surgido nesse período - o canal Pakapaka - como uma expressão das 
políticas para a comunicação pública e de suas possibilidades de articular a questão da representação e voz do lugares.

\title{
4.2.1. A comunicação alternativa, comunitária e popular e o financiamento dos meios sem fins lucrativos
}
Esta boludez de "hagamos la radio de los wichis", ¿quién carajo va a escuchar la radio de los wichis? Y lo que es peor, ¿quién va a poner avisos en la radio de los wichis? ¿Y cómo le van a pagar el sueldo a los operadores?

Jorge Lanata, entrevista a La Nación (2012a).

\begin{abstract}
Quem nunca esteve em um piquete, seguramente não entenderá o que significa e encerra. O corte de rota não é simplesmente um bloqueio de caminhos; é, também, liberar uma porção de território onde se desenvolve um mundo inteiro e novo, nascido da necessidade, mas caminhando lentamente para a dignidade. [...] A analogia do piquete na rua com a TV piqueteira é quase perfeita, porque ela não pode ser tomada como nada além de uma incursão na frequência radioelétrica; não se trata somente de apropriar-se do espaço geralmente dominado pelos monopólios da comunicação, mas de colocar em prática novas relações entre o homem e a mídia.
\end{abstract}

Indymedia Argentina. El rol de los medios alternativos (2004, trad. nossa).

Após o fim da ditadura em 1983, o processo de redemocratização na Argentina acompanhou o avanço da pauta da democratização da comunicação, como visto anteriormente. O marco normativo vigente, da ditadura, proibia expressamente o acesso de organizações sem fins lucrativos ao espectro radioelétrico. Após debates do tema no início do governo Alfonsín, essa norma acabou não sendo transformada até a década de 2000. Assim, a forte organização popular existente acompanhou, nos anos 1980, uma intensa proliferação de rádios chamadas de clandestinas, ilegais ou truchas pelos meios comerciais e pelo Estado - enquanto no início da década havia uma dúzia dessas rádios, em 1987, já eram cerca de 2 mil e, em 1989, 3 mil (VINELLI, 2014, p. 80). Entre elas, havia uma grande diversidade de organizações e sentidos - rádios comunitárias, emissoras vinculadas a associações de bairros, rádios livres e populares, até rádios vinculadas a políticos e pequenos empreendimentos. Cerca de 500 dessas 
rádios, mais tarde, se reivindicaram como alternativas (LAMAS; LEWIN, 1995).

No auge da expansão das rádios alternativas, surgiram iniciativas e esforços para a transmissão televisiva, já em $1987^{86}$. Conforme Natalia Vinelli, em entrevista ${ }^{87}$, o contexto de nascimento das organizações que pleiteavam uma televisão alternativa, comunitária e popular está relacionado à hegemonia da televisão na comunicação, além da força das organizações populares no país. Segundo ela, houve muitas ações de grupos de comunicação em bairros, em que eram montadas as estruturas para transmissão e se gravava e transmitia às pessoas, mostrando outras possibilidades da televisão. Após a primeira transmissão de um canal alternativo em 1987, já em 1989 foi montada uma associação das teledifusoras comunitárias, a Ateco (VINELLI, 2014, p. 86), para promover novas iniciativas de televisão comunitária - que perdurou, nesses moldes, até meados dos anos 1990. Havia influência e articulação com o cinema militante e, posteriormente, com o chamado cinema piqueteiro (ZAROWSKY, 2004, p. 81).

Fato é que a trajetória desses meios, na Argentina e na América Latina como um todo, se construiu por fora das vias legais, e seu direito a exercer a liberdade de expressão através da propriedade de meios de comunicação foi ignorado sistematicamente pelo Estado (ESPADA, 2017, p. 80). Segundo Segura (2016, p. 115), apesar da inserção social e territorial e do enorme trabalho cotidiano, os meios do setor social-comunitário não eram reconhecidos legalmente como prestadores de serviços de radiodifusão em nenhum país da região até 2004.

Qualificando as definições formais e normativas que abrangem as práticas de comunicação usualmente chamadas de comunitárias, é importante avançar em sua significação a partir dos agentes que a produzem no território

\footnotetext{
86 Mais detalhes sobre essa trajetória estão em Vinelli (2011a, 2014).

${ }^{87}$ Entrevista de Natalia Vinelli ao autor, realizada em setembro de 2017 na sede da Barricada TV, no Centro Cultural IMPA em Almagro, cidade de Buenos Aires. Vinelli é fundadora da Barricada TV, militante da comunicação alternativa, popular e comunitária na Argentina, pesquisadora do tema e docente da Universidad de Buenos Aires (UBA).
} 
argentino. Vinelli (2013, p. 3-4, tradução nossa) define a comunicação alternativa,

popular e comunitária como um tipo de práticas comunicacionais que:

(1) estão comprometidas com os interesses das classes e grupos populares, cuja finalidade não se esgota em si mesma, mas que é parte de um projeto de transformação e construção de contrahegemonia que the dá sentido e orientação, e que compõe outro modelo de sociedade; (2) que surgem e se desenvolvem a partir da necessidade de recuperar a palavra, o ato afirmativo da fala e, portanto, para dar visibilidade às vozes silenciadas ou distorcidas pela mídia hegemônica; (3) que estão intimamente relacionadas ou inseridas em movimentos sociais e organizações políticas populares e de trabalhadores, dos quais são expressão, e que cumprem uma função de articulação na medida em que estes se apropriam da experiência; (4) que propõem outro paradigma de comunicação que não está regido pelo lucro nem pela lógica do dinheiro, mas pela comunicação como bem social e direito humano; (5) que buscam romper com o esquema unidirecional da comunicação, trabalhando no envolvimento ativo do público, fomentando a participação e construindo a estética em conjunto com a comunidade de pertencimento, colocando em questão os critérios de "profissionalismo"; (6) que são de propriedade coletiva, social, comunitária ou popular, e autogestinada; e, portanto, não estabelecem de nenhuma maneira relações de patrão / empregado; (7) que constroem sua programação e sua agenda a partir de outros critérios de noticiabilidade e de relacionamento com os protagonistas, dando lugar a um discurso jornalístico de contra-informação.

Frente à televisão global, nacional e até regional, a televisão comunitária faz da vizinhança e da proximidade a base de sustentação de seu projeto - às vezes expresso em formas de militância territorial e política transformadora; outras vezes, como um espelho da identidade local, onde as pessoas do lugar podem se reconhecer (VINELLI, 2014, p. 117). É possível pensar seu papel na enunciação dos lugares considerando que "o discurso fabrica o lugar: o lugar da vida cotidiana, da repetição, do trabalho (ou da ausência ele), mas também da criatividade e da subversão" (SERPA, 2011, p. 16). Esses meios estão ligados, portanto, à produção de informações ascendentes, arraigadas ao lugar, ao dilema da sobrevivência, da resistência e da reprodução, tratando do 
cotidiano compartilhado (SILVA, 2010). Eles podem ser considerados, ainda, como "entrelugares do acontecer político e cultural que se transformam paulatinamente em objetos urbanos apropriados de modo criativo e político pelas classes populares" (SERPA, 2011, p. 31).

Na década de 1990, houve um recuo no fenômeno de expansão da televisão comunitária no território argentino. Entre os principais motivos para esse recuo, estão: a intensa perseguição por parte do Estado, devido à norma que proibia acesso desses meios ao espectro; o desgaste produzido pela aproximação de muitos meios com os modelos e práticas hegemônicas; e a expansão da televisão paga (VINELLI, 2014, p. 157). Ao mesmo tempo, outras condições eram produzidas para que esse movimento ressurgisse na virada de século. Entre elas, destacam-se: a crise do neoliberalismo na Argentina e a busca por formas de participação (CALICCHIO, 2011, p. 80); a expansão da formação profissional para o audiovisual, mas com um mercado de trabalho limitado pelos monopólios (VINELLI, 2014, p. 159); e as características das tecnologias do período, que são mais facilmente apropriadas para usos não-hegemônicos, como narra Santos (2000, p. 165):

as famílias de técnicas emergentes com o fim do século XX - combinando informática e eletrônica - oferecem a possibilidade de superação do imperativo da tecnologia hegemônica e paralelamente admitem a profileração de novos arranjos, com a retomada da criatividade.

Assim, no período próximo à crise de 2001, houve uma grande expansão dos meios alternativos, com novos agentes surgindo e um fortalecimento dos que já estavam em atuação (ESPERÓN; VINELLI, 2004, p. 25). Nessa nova expansão, diversas experiências de televisão alternativa, popular e comunitária, em canais analógicos, fizeram forte trabalho de propaganda em seus lugares, buscando firmar o compromisso da comunidade, sua participação e, também, informar sobre questões técnicas - sobretudo a necessidade de uma antena de televisão, em um cenário fortemente marcado pelo predomínio da 
televisão paga a cabo (VINELLI, 2014, p. 164).

Na década de 2000, muitas emissoras comunitárias de rádio e televisão participaram da disputa por uma regulação democrática da comunicação, várias delas na Coalizão por uma Radiodifusão Democrática - como as nucleadas no FARCO, o Fórum Argentino de Rádios Comunitárias (CALICCHIO, 2011, p. 74). Conforme Espada (2017, p. 80, tradução nossa), "a inclusão do setor sem fins lucrativos como um ator fundamental dentro da diversidade de vozes buscada pela LSCA foi uma das bandeiras que impulsionaram seus proponentes e militantes". Essa inserção na pauta não foi realizada de forma homogênea nem sem tensões, já que há uma grande diversidade de concepção política e de relação com o Estado e com a institucionalidade entre esses agentes - vários consideram que essa aproximação com o Estado significaria cooptação (HENKEL; MORCILLO, 2014, p. 81). Como relatou em entrevista Natalia Vinelli (2017a), diversos grupos de comunicação comunitária tiveram posturas distintas nessa relação com a institucionalidade e o Estado na construção da LSCA e nas reivindicações posteriores - o que acompanhou uma diversidade de redes e associações com diferentes propostas de inserção. Essa tensão é antiga conforme Vinelli (2014, p. 38, tradução nossa), "o desconforto da alternatividade tem a ver com sua história, que sempre foi rebelde à formalização conceitual e que está muito associada à prática (comunicacional, social e política)". A contrainformação pressupõe enfrentamento, não só contra o discurso oficial, mas contra a ordem estabelecida (ESPERÓN; VINELLI, 2004, p. 17).

Uma das reivindicações anteriores à aprovação da LSCA estava articulada com a questão normativa de reconhecimento e permissão legal de operação. Conforme Lazzaro (2010, p. 197), o primeiro avanço se conquistaria em agosto de 2005, quando um projeto para acabar com a exclusão inconstitucional das cooperativas e meios comunitários reformou o artigo 45 da lei 22.285/1980, o marco normativo da ditadura, permitindo que as associações sem fins lucrativos fossem titulares de outorgas de radiodifusão. Em 2006, o Comitê Federal de 
Radiodifusão (que antecedeu a AFSCA) reconheceu as organizações não comerciais e, no ano seguinte, entregou a primeira licença para uma entidade desse tipo - a Rádio Encuentro, em Viedma, Río Negro (ESPADA, 2017, p. 83).

A LSCA trouxe mudanças em relação aos meios sem fins lucrativos, manifestadas em três fatos: o reconhecimento da comunicação sem fins lucrativos como um âmbito sujeito a exercer seu direito à comunicação; a reserva de 33\% do espectro radioelétrico para que essas organizações obtenham licenças; e a criação de um fundo de fomento - o Fundo de Fomento Concursável para Meios de Comunicação Audiovisual (FOMECA), gerenciado pela AFSCA - para garantir sustentabilidade econômica a esses meios (ESPADA, 2017, p. 79). Todas essas medidas articulam o sentido de promover melhor condições normativas, técnicas e financeiras para a atuação e crescimento desses meios.

Esse processo se deu a partir das lutas e demandas constantes das organizações e movimentos de comunicação que, após a aprovação da lei, seguiram pressionando para a efetivação das previsões legais e pautando a AFSCA em relação ao setor (COALICIÓN POR UNA RADIODIFUSIÓN DEMOCRÁTICA, 2013; RED NACIONAL DE MEDIOS ALTERNATIVOS, 2013). Além de um grande número de protestos e manifestações públicas, os espaços participativos ou com abertura ao diálogo com o setor, por meio do qual os reclamos dos meios comunitários se faziam presentes na AFSCA institucionalmente, eram o Conselho Federal de Serviços de Comunicação Audiovisual (Cofeca) e a Defensoría del Público ${ }^{88}$ - enquanto outros desses meios decidiram não dialogar com o Estado.

Ainda em 2009, a autoridade de aplicação da lei realizou um censo declaratório de meios, identificando 1053 organizações sem fins lucrativos todavia, 80\% delas nunca haviam transmitido ou estavam inativas (ESPADA, 2017, p. 84). Em 2008, outro levantamento indicava que havia 175 rádios sem fins

88 A Defensoría del Público foi um órgão criado pela LSCA, autônomo, voltado à proteção dos direitos do público, atuando desde a promoção, difusão e defesa do direito à comunicação até a proteção de outros direitos articulados com a liberdade de expressão, como questões de discriminação. 
lucrativos reconhecidas, pertencentes a grupos religiosos, indígenas ou universidades, representando cerca de 9\% das 1940 frequências registradas (BECERRA; MARINO; MASTRINI, 2012, p. 22), sem contar as fora do controle do Estado. Há poucos dados sobre televisão, mas estima-se que em 2012 havia cerca de vinte (ESPADA, 2017, p. 82). Conforme Espada (2017), esse setor é diverso e federal, estando presente em todas as regiões do país, com uma concentração de organizações nas cidades maiores. A maioria são rádios $F M$, ainda que nos últimos anos tenham crescido os operadores de televisão a cabo (ESPADA, 2017, p. 80).

Além do reconhecimento legal da existência e importância desses meios, ressaltam-se as outras duas dimensões principais das políticas no marco da LSCA: a normatização e o acesso ao espectro, por meio das licenças, e a promoção de condições de financiamento para a vocalização desses agentes. Antes da análise, no entanto, é importante lembrar, conforme Vinelli (2014, p. 24, tradução nossa), que te trata de um objeto indisciplinado, cuja ênfase está no processo e nas possibilidades de intervenção política dos coletivos que o impulsam. Segundo a autora,

o desenvolvimento dos meios alternativos, comunitários e populares está diretamente relacionado com a situação do campo popular, o estado da luta de classes e as estratégias de transformação social, o que impede de "medílos" ou reinvindicar "resultados" mediante esquemas quantitativos, rentáveis e de curto prazo.

No tema das licenças para a ocupação do espectro radioelétrico, houve diversas disputas - a começar pela conceituação prevista na lei. Embora a LSCA traga uma definição do que é um meio comunitário, ela não é resgatada posteriormente, exceto no FOMECA. Assim, até a reserva do espectro, dos 33\%, é feita para meios sem fins lucrativos em geral ${ }^{89}$. Ao igualar os demais meios sem fins lucrativos na norma, foram criadas condições desiguais de concorrência às

\footnotetext{
89 Não estão incluídos nessa categoria as escolas e Universidades, reconhecidas como atores de direito público estatais, e a Igreja Católica e os povos originários, reconhecidos como atores de direito público não-estatais.
} 
licenças entre meios comunitários, alternativos e populares e outros como fundações de grandes empresas, organizações não-governamentais ligadas a igrejas, grandes sindicatos e associações. Isso teria imposto grande dificuldade aos meios alternativos, populares e comunitários nos primeiros anos para acesso às licenças.

Conforme Vinelli (2017), os primeiros concursos lançados em 2011 - e posteriormente suspensos, após muitas críticas do setor comunitário - não criavam condições mínimas para a participação de meios comunitários populares - desde as taxas cobradas até questões burocráticas que não condizem com as práticas alternativas desses meios, como a exigência do quadro de funcionários. Mesmo que fosse viável a inscrição, a concorrência na apresentação da documentação era feita com propostas de agentes com desigual poder econômico, escala e formas de trabalho. As novas chamadas de concorrência, em 2015, foram realizadas após diálogos com o setor e, ainda que permanecessem algumas dificuldades, era possível para esses meios disputarem o acesso a licenças e algumas foram obtidas.

No total, foram 1537 licenças ou autorizações outorgadas pela AFSCA entre 2009 e 2015 (24), sendo 1255 delas para rádios.

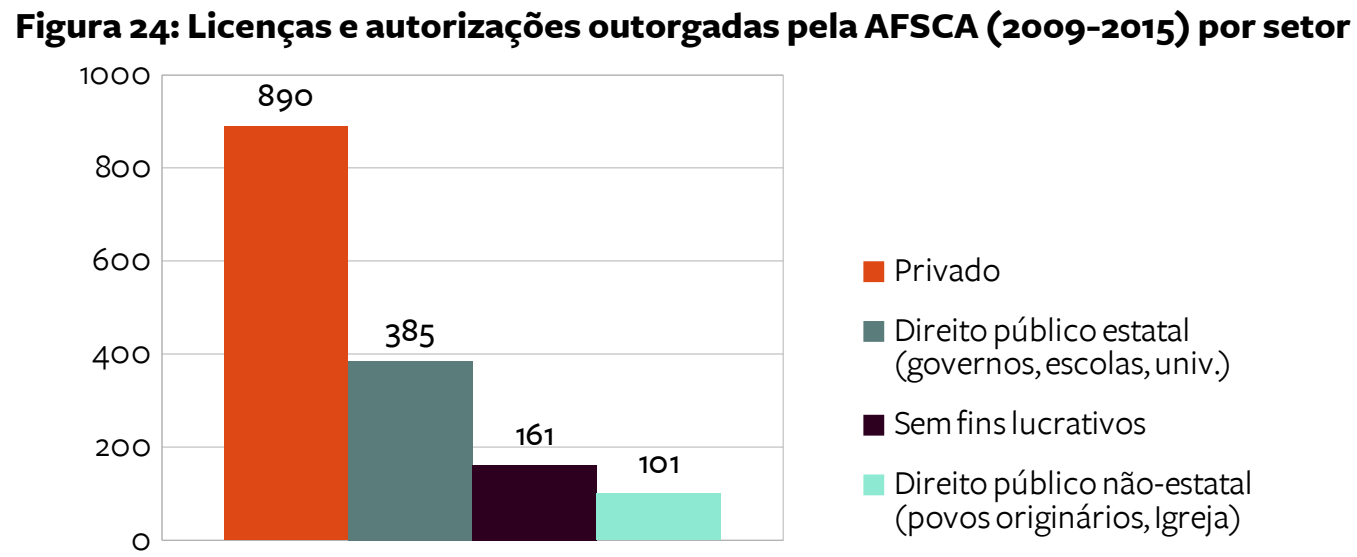

Elaboração própria. Fonte: Espada (2017), com base em dados da AFSCA.

É possível observar que 161 dessas licenças ou autorizações (pouco mais de 10\%) foram destinadas a meios sem fins lucrativos, mas considerando as 
licenças não-privadas (sem fins lucrativos e de direito público estatal e nãoestatal), são cerca de $42 \%$ do total outorgado.

Ainda segundo levantamento de dados da AFSCA presente em Espada (2017), considerando essas 161 licenças ou autorizações, a maioria delas (77\%) foi distribuída sem concurso, por designação direta. Também percebe-se que os canais a cabo são maioria entre os tipos de mídia, seguidos pelo rádio (25).

\section{Figura 25: Licenças e autorizações outorgadas pela AFSCA (2009-2015) ao setor sem fins lucrativos, por meio e tipo de distribuição}

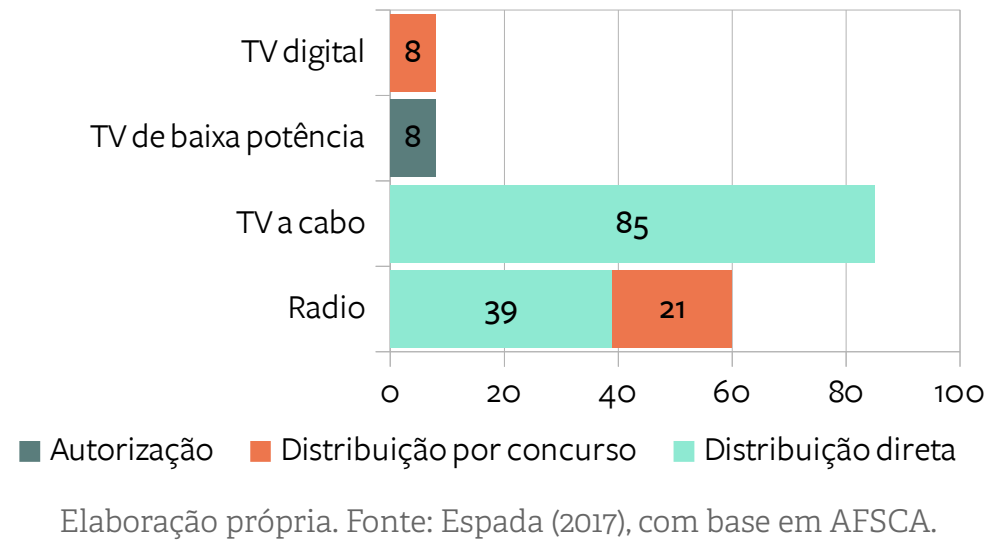

A presença da distribuição direta, especialmente no caso das rádios, deu-se por um instrumento da LSCA voltado a espaços opacos - no seu artigo 49, prevê um regime especial para emissoras de baixa potência, onde haja comprovada disponibilidade de espectro, em regiões de alta vulnerabilidade social e/ou de escassa densidade demográfica, sempre que sua programação esteja compromissada com a satisfação de demandas comunicacionais de caráter social (ARGENTINA, 2009c, p. 28). Esse foi o mecanismo legal usado para as 39 rádios assignadas. As oito autorizações provisórias foram dadas a canais televisivos - três deles conseguiram, em 2015, aprovação em concurso para a televisão digital.

O Mapa 9 demonstra a distribuição por província do total de licenças e autorizações outorgadas para a rádio e para a televisão, agrupando os dados de televisão a cabo, digital e analógica de baixa potência. 


\section{Mapa 9: Licenças e autorizações de rádio e televisão emitidas pela AFSCA (2009-2015) para meios sem fins lucrativos por província}

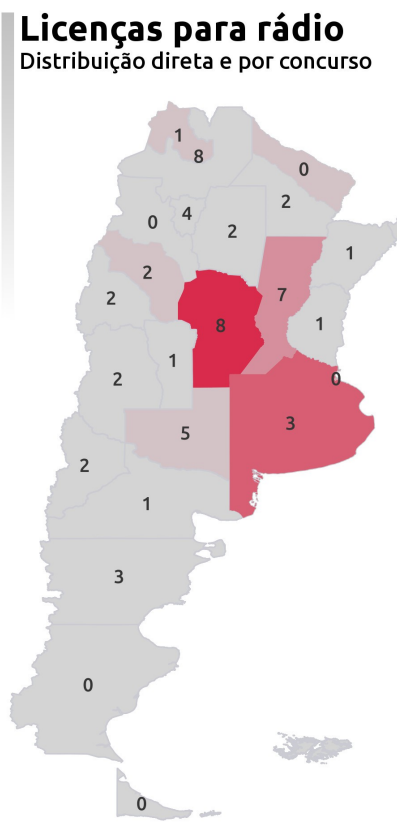

Número de licenças outorgadas

Número de licenças outorgadas
0
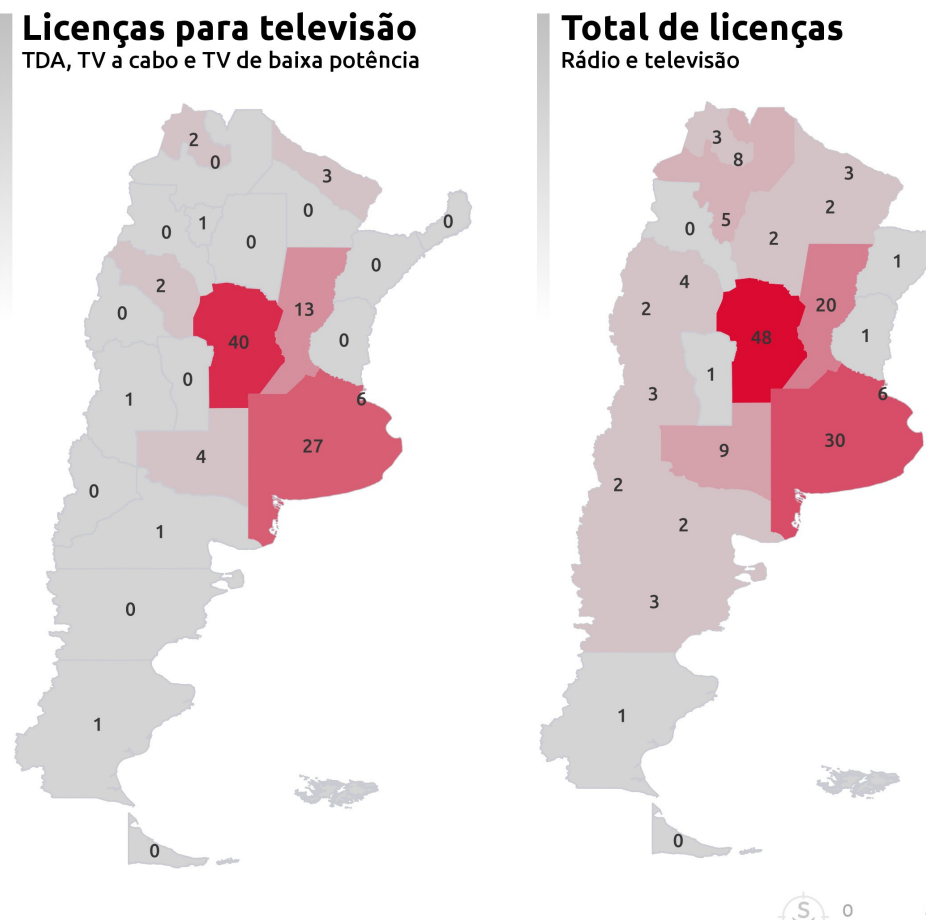

Elaboração: André Pasti. Desenvolvido com os softwares livres QGIS e GIMP. Fonte: Espada (2017), com base em AFSCA.

É possível notar, em destaque, as províncias de Córdoba, Buenos Aires e Santa Fe. Entre outros fatores históricos da organização espacial dessas províncias, para Espada (2017, p. 89), isso seria explicado também em função de serem províncias com forte presença do movimento cooperativo no setor de serviços públicos. Ainda que se tenha avançado nessa distribuição de licenças, há várias regiões onde a demanda foi pouco ou nada atendida. Espada (2017) considera que essa distribuição foi insuficiente para equilibrar o sistema de meios. Em entrevista de um dos ex-diretores da AFSCA, Santiago Aragón, mencionada em sua obra, há a explicação de que grande parte dos esforços da autoridade de aplicação da lei estavam voltados às ações para limitar a concentração de propriedade dos grandes conglomerados, deixando algumas dificuldades de agilidade para efetivar processos como o de ocupação dos 33\% do espectro reservados para a comunicação sem fins lucrativos. 
Desdobrando os dados para as licenças e autorizações de televisão, é possível identificar, por província as diferenças entre televisão de baixa potência, televisão digital e a cabo (Mapa 10).

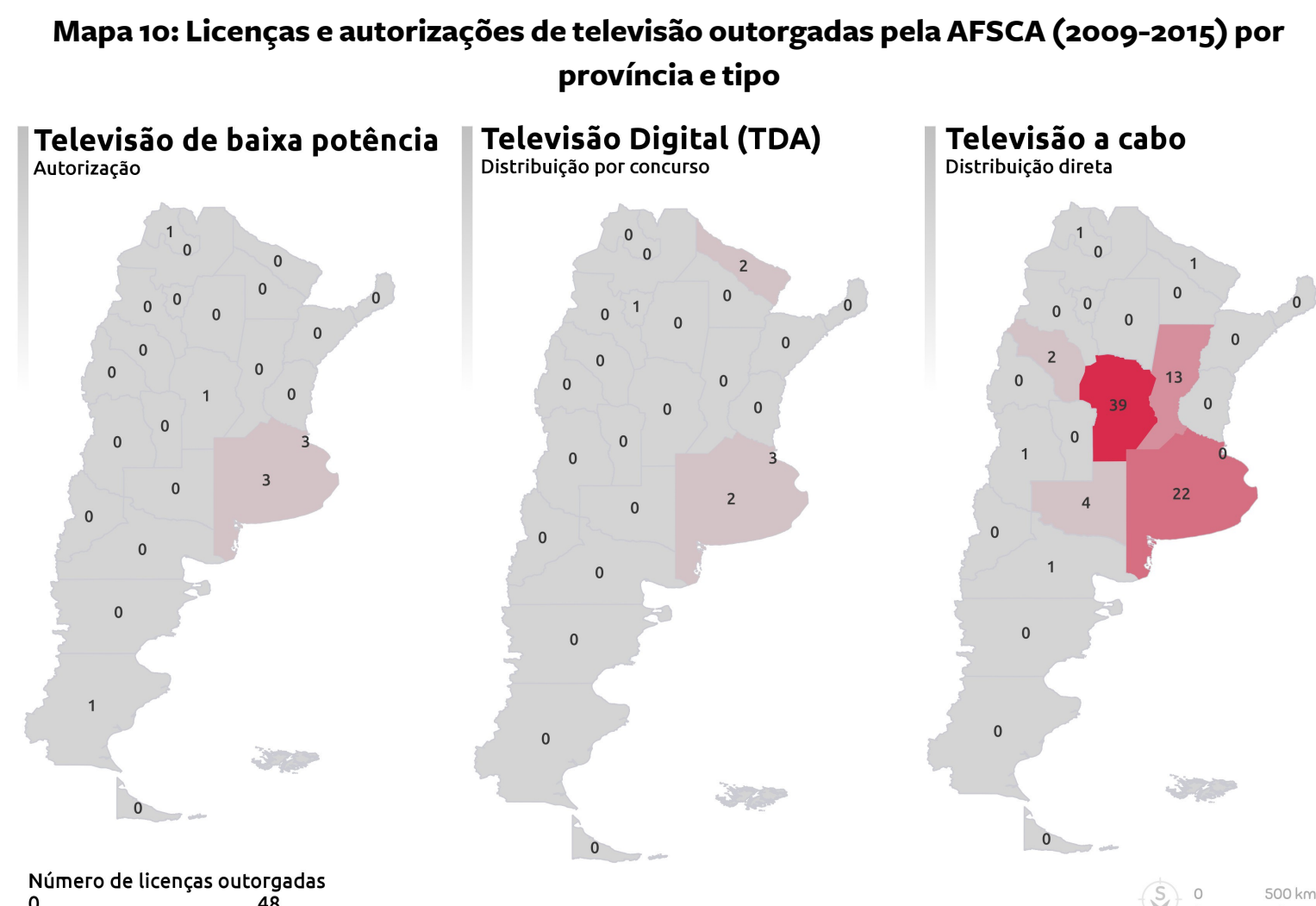
Número de licenças outorgadas
$0 \quad 48$

Elaboração: André Pasti. Desenvolvido com os softwares livres QGIS e GIMP. Fonte: Espada (2017), com base em AFSCA.

Observa-se que as licenças distribuídas para a televisão a cabo são a maioria - já que não há limite imposto pelo espectro - e que concentram-se, também, em Córdoba, Buenos Aires e Santa Fe.

As licenças e autorizações não estavam em cidades chamadas de "zonas de conflito" do espectro, as maiores cidades, onde há mais demanda que espaço disponível para a radiodifusão. Por esse motivo, a partir de demanda das redes de meios comunitários, no final de 2014 foi realizado um registro voluntário de rádios de organizações sem fins lucrativos, identificando 182 organizações (Mapa 11). Dessas, 140 foram reconhecidas oficialmente pelo AFSCA no fim de novembro de 2015, permitindo maior acesso aos fundos de 
financiamento e concursos por licenças. Ainda 39 delas tiveram uma faixa do espectro radioelétrico reservada, para conseguir, posteriormente, suas licenças.

\section{Mapa 11: Organizações registradas pela AFSCA (2015) em zonas de conflito do espectro radioelétrico}

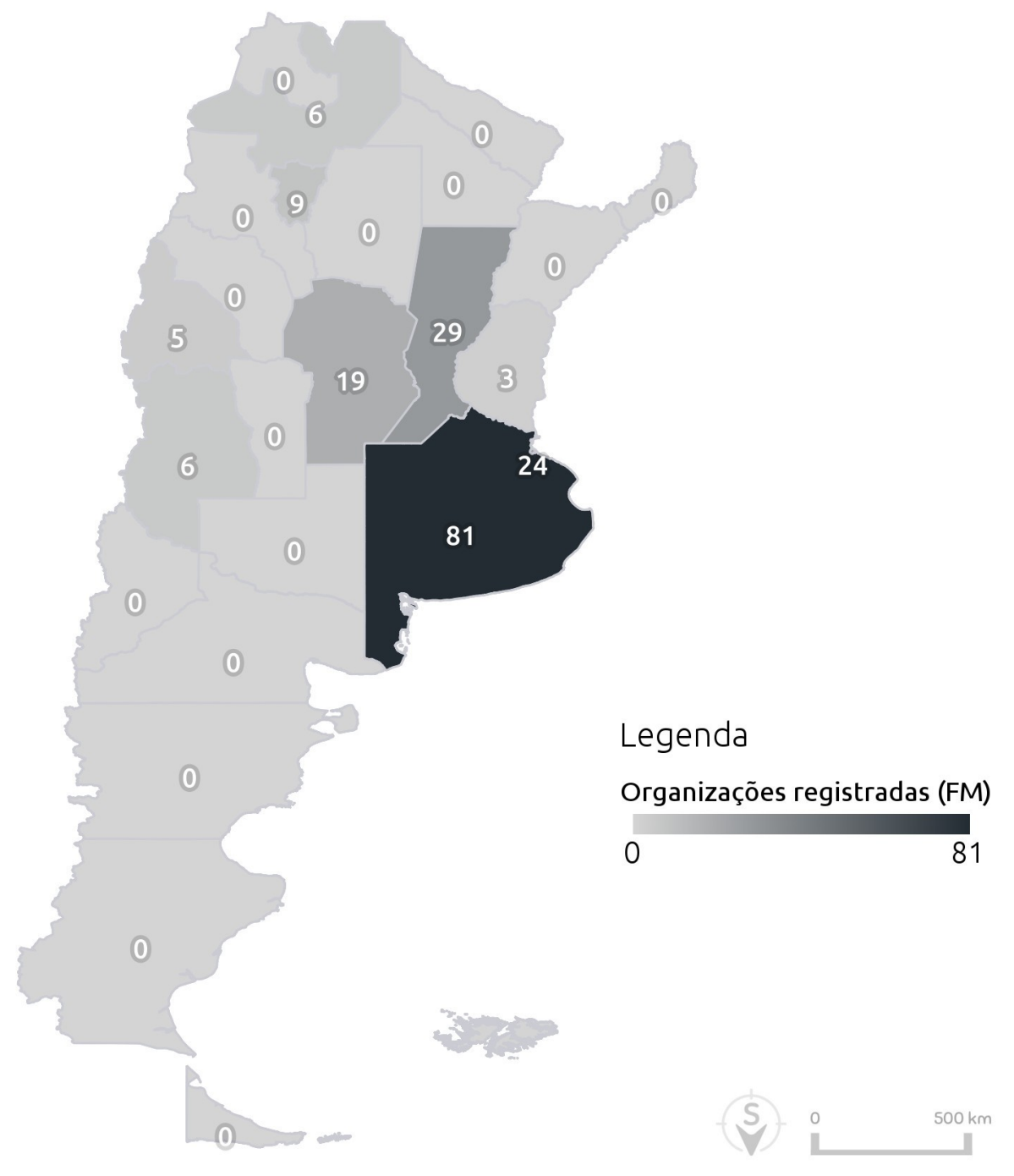

Elaboração: André Pasti. Desenvolvido com os softwares livres QGIS e GIMP. Fonte: Espada (2017), com base em AFSCA.

A distribuição das organizações registradas por província dá destaque à capital, Buenos Aires (em função do conurbano da capital), Santa Fe e Córdoba.

No caso da televisão digital, meios comunitários conseguiram licenças efetivas para canais alternativos, populares e comunitários como Barricada TV ${ }^{90}$,

9o Para ilustrar o processo dessas televisões comunitárias, alternativas e populares, a Barricada TV - noticiero 
Comarca Si e Urbana TeVé (CABA), Pares TV (Lujan, Buenos Aires), Comarca Si e EnTV (Viedma, Río Negro), além da licença ao canal Wall Kintun TV, para povos originários.

As condições técnicas e financeiras para a produção e circulação de informações são muito desiguais no território - o que exige políticas públicas que atuem na criação de condições nos lugares, especialmente aqueles espaços silenciosos (ROJAS, 2014). Nesse sentido, uma demanda histórica - e repleta de tensões - trata sobre as condições financeiras e normativas para a viabilidade dos projetos de comunicação alternativa e sem fins lucrativos. Conforme Vinelli (VINELLI, 2011b, p. 24), a capacidade desses meios serem massivos está associada à questão, mais conflituosa, do financiamento capaz de sustentar a estrutura de um canal de televisão alternativo.

A principal ação91 nessa área em relação aos meios comunitários foi a criação do Fundo de Fomento para Meios de Comunicação Audiovisual, o FOMECA. Previsto no inciso F do artigo $97^{92}$ da lei (ARGENTINA, 2009c), ele foi criado em 2013 e designou, até dezembro de 2015, 153.948.061 pesos a meios e

popular é uma televisão que transmitiu suas primeiras coberturas 2008,2009 , com programas informativos sobre agendas de protestos e conflitos. Segundo Vinelli (2017), em 2009 se instalaram em uma fábrica ocupada, recuperada pelos trabalhadores, hoje cooperativa e centro cultural IMPA, em Almagro, Buenos Aires. Ali, construíram o estúdio e desde março de 2010 transmitem regularmente - na ocasião, na televisão analógica. Ganharam concurso de licença em outubro de 2015 e no mesmo ano foram contemplados com edital de infraestrutura para televisão digital, com recursos para equipar seu centro de transmissão - foram, no total, 6 prêmios FOMECA (MARINO; GUIMERÀ ORTS, 2016). A licença da TDA que foi atribuída no concurso era a 33.1, mas o Canal 13, do Grupo Clarín, a estava usando em teste e continuou interferindo ilegalmente por um ano, até que, no fim de 2016, o órgão que substituiu a AFSCA ofereceu outra frequência para a BarricadaTV, a 32.1, para não "interferir" com o Canal 13 - nesse caso, subiram o alcance do sinal de cerca de $11 \mathrm{~km}$ para $17,7 \mathrm{~km}$. Para a licença, a BarricadaTV concorreu com uma grande igreja da região. A televisão tem sua programação de responsabilidade de 25 a 30 militantes que, toda semana, debatem a conjuntura política e a partir daí definem a agenda dos programas. Conseguiram recursos para liberar quatro dos militantes para dedicarem-se exclusivamente a tarefas operacionais do canal (na área técnica, administrativa, de relações politicas e institucionais e de programação). Entre seus programas, estão: La política por otros medios, Miserias de la Economía, IMPA es un Barrio, Ferro TV (sobre o Club Ferro Carril Oeste), entre muitos outros.

91 Vale destacar que houve ações de financiamento por meio do Programa Polos, além de concursos de produtos audiovisuais da TDA, outros concursos do INCAA, do Fondo Nacional de las Artes e ações difusas de financiamento, não voltadas diretamente a esses meios ou à produção para a televisão. A publicidade oficial estatal, também fonte de financiamento, teve apenas 0,4\% de seu total distribuído a meios comunitários entre 2009 e 2015, atingindo 35 organizações (ESPADA, 2017, p. 109).

92 O artigo 97 trata da destinação dos fundos arrecadados pela AFSCA. Seu inciso f estabelece que 10\% seriam destinados para projetos especiais e apoio ao audiovisual comunitário, de fronteira e a povos originários. 
produtoras audiovisuais comunitárias (ESPADA, 2017, p. 101), em diversas linhas que abrangem equipamentos para rádios, financiamento de programas de diversos formatos, gestão de meios comunitários, infraestrutura para televisão digital e outras, voltadas a emissoras e produtoras comunitárias.

Os fundos foram organizados em linhas com fins específicos e com a forma de acesso via concurso, com critérios voltados a atender organizações de comunicação comunitária de diferentes graus de consolidação e de acordo com o objetivo em questão. O Quadro 11 demonstra os prêmios de cada linha e ano.

Quadro 11: Linhas e prêmios financiados pelo FOMECA (2013 a 2015)

\begin{tabular}{|c|c|c|c|}
\hline Ano & Linha & Título & Prêmios \\
\hline \multirow{2}{*}{2013} & 1 & Equipamento & 23 \\
\hline & 2 & Produções de formato audiovisual e radiofônico & 60 \\
\hline \multirow{7}{*}{2014} & 1 & Equipamento para rádios & 19 \\
\hline & 2 & Comunicação com identidade (equipamento e produção radiofônica) & 20 \\
\hline & 3 & Produções audiovisuais (spot e microprograma) & 57 \\
\hline & 4 & Produções radiofônicas (programa semanal, diário ou informativo) & 131 \\
\hline & 5 & Gestão de meios comunitários & 43 \\
\hline & 6 & Produções audiovisuais (microprograma, semanal, spot e informativo diário) & 59 \\
\hline & 7 & Produções radiofônicas (comunitária e semanal) & 98 \\
\hline \multirow{15}{*}{2015} & 3 & Comunicação com identidade (equipamento e produção radiofônica) & 12 \\
\hline & 6 & Produção radiofônica emissoras (programa diário, semanal ou informativo) & 36 \\
\hline & 7 & Produção radiofônica produtoras (campanha comunitária e programa semanal) & 67 \\
\hline & 8 & Produções audiovisuais (microprograma, semanal e spot) & 76 \\
\hline & 13 & Comunicação com identidade (equipamento e produção radiofônica) & 9 \\
\hline & 12 & Equipamento para rádios & 41 \\
\hline & 15 & Produção de conteúdos radiofônicos para produtoras (semanal) & 48 \\
\hline & 5 & Gestão de meios comunitários & 37 \\
\hline & 16 & Produção audiovisual - produtoras (spot, microprogramas e semanal) & 66 \\
\hline & 2 & Equipamento e infraestrutura para emissoras de TV com licença ou autorização & 9 \\
\hline & 9 & Produção de conteúdos audiovisuais para emissoras de televisão & 9 \\
\hline & 10 & Formato redes nacionais & 5 \\
\hline & 14 & Produção de conteúdos radiofônicos para emissoras & 30 \\
\hline & 1 & Equipamentos para rádios & 42 \\
\hline & 4 & Gestão de meios (primeira concorrência) & 16 \\
\hline \multicolumn{3}{|c|}{ Total - 2013 a 2015} & 1013 \\
\hline
\end{tabular}

Adaptado de Espada (2017, p. 102). 
Percebe-se um crescimento nos anos de 2013 a 2015, e o reconhecimento de uma diversidade maior de linhas de fomento - que abrangem equipamentos, produção radiofônica e audiovisual e gestão dos meios. Ao analisar a distribuição geográfica desses prêmios (Mapa 12), é possível notar uma relativa desconcentração em relação à cidade de Buenos Aires.

\section{Mapa 12: Distribuição dos prêmios FOMECA por província (2013 a 2015)}

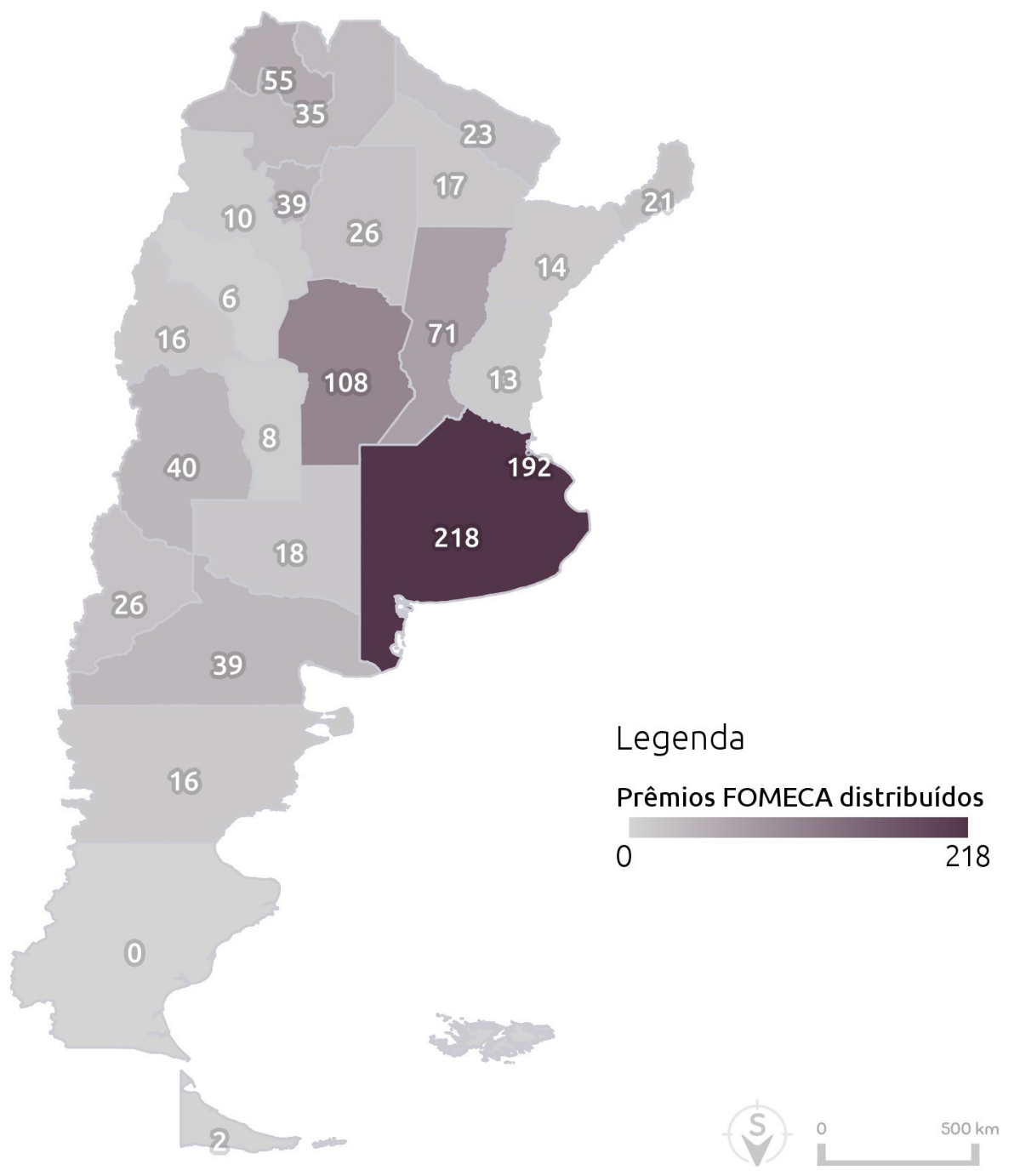

Elaboração: André Pasti. Desenvolvido com os softwares livres QGIS e GIMP. Fonte: Espada (2017), com base em AFSCA.

A capital concentrou $18,9 \%$ dos prêmios - ainda que, contando com o conurbano, a Província apareça com destaque (com 21,5\% do total). No entanto, com uma exceção (Santa Cruz), todas as demais províncias foram contempladas 
no FOMECA. Se considerarmos a regionalização dos Polos Audiovisuais, a distribuição fora da Província e cidade de Buenos Aires seria: NOA, 165 prêmios; NEA, 72; Centro-Este, 84; Centro, 104; Cuyo, 62; Patagônia Norte, 65; e Patagônia Sul, 20. Apesar da desigualdade em relação ao sul da Patagônia, as demais regiões demonstram uma distribuição considerável de recursos fora do centro de gestão do território argentino, apontando para uma descentralização e para a promoção de condições para o audiovisual em lugares silenciosos do território. Vinelli (2017) avalia que o FOMECA permitiu, para os meios que o acessaram, condições de crescer e ter acesso a objetos técnicos profissionais. Para Espada (2017, p. 110), o FOMECA foi um dos melhores aspectos da implementação da LSCA em relação ao setor comunitário. Esse conjunto de transformações normativas, financeiras e técnicas potencializou as condições de atuação de meios estreitamente ligados à produção de informação ascendente.

\subsubsection{Canais da televisão pública, território e sentidos regionais}

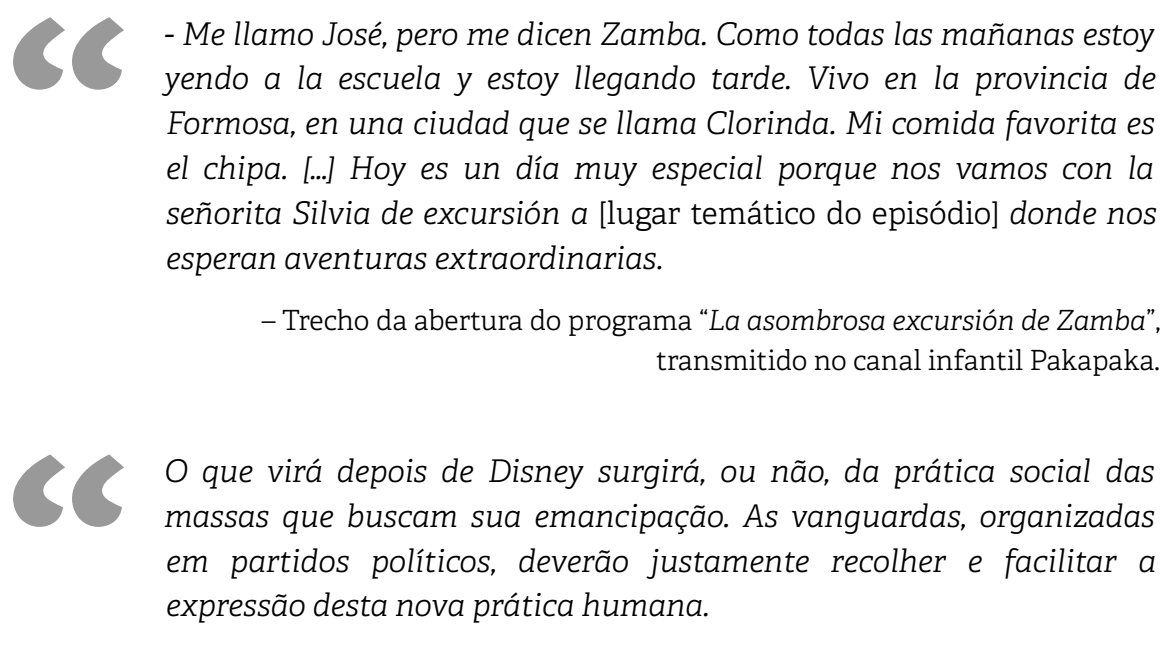

Ariel Dorfman e Armand Mattelart, Para ler o Pato Donald (2010)

Ainda buscando analisar ações no bojo da LSCA que, de algum modo, articularam condições para a ampliação da densidade comunicacional dos lugares, pretende-se fazer o registro e uma breve análise de alguns dos novos sentidos de canais de televisão pública em relação à regionalização e os espaços silenciados pela mídia comercial concentrada. A busca de uma televisão pública 
de qualidade ${ }^{93}$, para Maria Luiza Viana, seria

reflexo da cultura nacional, de ter um espaço onde essas vozes e o pluralismo social estejam refletidos também na televisão, ter um lugar onde seus criadores possam desenvolver novos programas e formatos e não ficar somente repetindo fórmulas que são produzidas em outros lugares (EBC, 2014).

Entre as transformações que acompanham a realização do evento geográfico LSCA no território, merece destaque a criação de diversos canais gestionados pelo Estado, que se somaram ao Canal 7 e à Radio Nacional: Encuentro, cultural; Pakapaka, infantil; IncaaTV, cinema; TecnópolisTV, ciência e tecnología; e DeporTV, de esportes (BECERRA, 2013), vinculados a estratégia de produção de conteúdos para a TDA (LABATE; CARBONI, 2014). Alguns deles tem princípios alinhados com os objetivos da televisão pública (BECERRA; WAISBORD, 2015, p. 14-15) com uma concepção de televisão vinculada ao território. Nesse sentido, cabe destacar que os canais Encuentro - que precede a aprovação da LSCA - e Pakapaka, ambos de responsabilidade do Ministério da Educação. Daremos ênfase, nessa breve análise, às dinâmicas ligadas ao canal Pakapaka.

O Encuentro foi criado em 2005 e transmitiu desde 2007, apresentando conteúdo educativo e de cidadania, com uma perspectiva regional transmitindo produções de todo o território argentino e de outros países da América Latina. Segundo González e Novomisky (2012, p. 79), o canal Encuentro serviria de experiência para novas apostas do Estado nacional em produtos audiovisuais, pois ele daria visibilidade a temas que os meios hegemônicos não

93 Conforme Becerra e Waisbord (2015), a história dos meios de comunicação de propriedade pública na América Latina mostra um desenvolvimento sinuoso, com uma quantidade significativa de iniciativas com aspirações e resultados mistos. Na maioria dos casos, funcionaram como prolongamentos do aparato comunicacional do poder executivo. Os processos envolvendo os canais que pretendem fazer comunicação pública no continente são repletos de processos contraditórios em sua relação com o Estado, de avanços cíclicos e raramente seguem todos os princípios propostos como boas práticas, da gestão à programação (BECERRA; WAISBORD, 2015). Monje, Rivero e Zanotti (2017, p. 85) afirmam que pensar em critérios prescritivos do que são "boas práticas" implicaria no risco de separar a análise dos conflitos, das tradições próprias e dos limites de onde opera cada meio - demandando interpretações do contexto baseadas em leituras complexas sobre o poder, o sistema midiático e as relações de força. 
tratam. Segundo os autores,

até a chegada do Encuentro não havia produtos culturais que abordavam temas como a educação, os direitos humanos, a igualdade de gênero, cine artístico, tribos originárias e um sem-fim de eixos que param nas portas dos canais tradicionais e suas grades de programação.

A particularidade do Encuentro, para Pauloni et al. (2017), foi ter sido pensado como um canal educativo, mas que toma como base elementos de canais culturais. O destinatário principal, quando de sua criação, era o sistema educacional, mas seus conteúdos também deveriam ser atrativos para o público televisivo em geral. O canal Pakapaka, criado em 2010, surgiu como uma faixa de conteúdo infantil do canal Encuentro, para posteriormente se tornar um canal próprio (GONŹALEZ; PAULONI; CODONI, 2016).

Conforme González e Novomisky (2012, p. 79), o Pakapaka teria surgido em um momento de vazio de conteúdos infantis gerados a partir da televisão argentina - para os autores, o vazio seria maior ainda se considerarmos conteúdos educativos, regionais e igualitários. Para Murolo (2013, p. 90), o Pakapaka tem um sentido público, tendo sido concebido no contexto comunicacional da LSCA para cumprir o objetivo de criação de novos espaços com conteúdos diferenciados e um caráter federal.

Segundo Borges (2008), uma televisão pública de qualidade pode ser discutida a partir de parâmetros valorativos definidos de acordo com as funções que se espera que o serviço público de televisão desempenhe num contexto político, econômico e social específico. Daí buscarmos entender os princípios que organizam o papel anunciado do canal Pakapaka.

O próprio Pakapaka (2015b) define como objetivo central do canal garantir a todas as crianças o acesso a conteúdos culturais e educativos de qualidade que contribuam a seu desenvolvimento integral, a partir de uma perspectiva de direitos. Outros objetivos eram: gerar uma programação de alta qualidade dirigida ao público infantil que estimule a criatividade e a imaginação, 
que promova a diversidade e a inclusão e que desperte o interesse pelo conhecimento; colocar material educativo audiovisual e digital à disposição de professores e alunos voltados a acompanhar o processo de ensino/aprendizagem em diversas áreas curriculares e a favorecer o uso das tecnologias da informação e da comunicação nos processos pedagógicos; desenvolver propostas interativas e multiplataforma atrativas e de qualidade que convoquem à participação e produção criativa das crianças; e promover ações territoriais ao redor de todo o país com o objetivo de que crianças se relacionem com os conteúdos e personagens do canal, através de propostas artísticas como festivais, mostras, obras de teatro e atividades em diferentes eventos. O canal possuía programação para crianças de 2 a 12 anos, em três faixas: 2 a 4 anos, 5 a 9 anos e 10 a 12 anos.

Eram dois os pontos de partida principais do Pakapaka, conforme Salviolo (2012): o primeiro dizia respeito ao papel dos meios públicos e da televisão pública, e o segundo sobre a infância.

Em relação ao primeiro, na concepção que baseava a organização do canal, os meios públicos eram entendidos como espaços onde todos se sintam representados. Esses meios deveriam apostar na integração entre cultura, comunicação e educação e ser um espaço em que todos os atores encontrem as mesmas oportunidades para se empoderarem, serem visibilizados e escutados. Considerando o direito à comunicação de todos, partiriam de uma visão distinta dos meios comerciais. Segundo Agrelo (2016), a perspectiva do canal era de ser uma televisão popular, disputando efetivamente a audiência.

Já em relação à infância, o canal entendia as crianças como sujeitos de direito, cidadãs, produtoras de cultura e construtoras da sociedade que integram. Assim, a qualidade da programação diria respeito à diversidade e à representação de todas as formas de ser criança no país, dando protagonismo a elas - com suas formas de ver o mundo, as perguntas que fazem, suas inquietações e seus interesses (SALVIOLO, 2012), levando em conta a diversidade regional existente no território argentino. 
Conforme uma das entrevistas realizadas com o então coordenador geral do canal, Facundo Agrelo ${ }^{94}$, havia um trabalho integrado do Ministério da Educação com a equipe técnica, que contemplava uma compreensão política do que é a infância nessa perspectiva de um marco de reconhecimento de direitos. Eram elaboradas, assim, concepções de criação de conteúdos para expressar para as crianças os distintos direitos, como direitos humanos, diversidade, direito à comunicação e à identidade.

Ainda segundo a entrevista (AGRELO, 2015), a produção audiovisual do Pakapaka era concebida pela equipe do canal e executada com uma diversidade de processos criativos. Em alguns casos - a minoria -, todas as etapas eram desenvolvidas com a equipe interna; em outros - a grande maioria - ocorria em parceria com produtoras de audiovisual do país, selecionadas por editais, seguindo os conceitos desenvolvidos pela equipe do canal. Nessas coproduções, havia um acompanhamento sistemático da equipe do Pakapaka para garantir os conceitos trabalhados nos programas. Em cada etapa, havia um acompanhamento por um conteudista, em geral pessoa especializada sobre os conteúdos em questão, que também trabalhava com a infância; e um produtor delegado do próprio canal, que era responsável pelo nexo entre o canal e a produtora. Cada produtor delegado tinha de 6 a 8 projetos simultâneos (AGRELO, 2015) e era responsável por gerenciar, atribuir tarefas e garantir, episódio a episódio, que o programa siga as diretrizes do Pakapaka. Desse modo, os canais buscavam contribuir para o fomento ao surgimento de novos agentes produtores, além de fornecer conteúdo audiovisual gratuito para novos canais regionais. Houve um crescimento da coprodução nacional já entre 2009 e 2011 na televisão argentina (2) - o que, segundo Lara (2013), poderia indicar a entrada de mais atores na produção de conteúdos televisivos.

94 Entrevista de Facundo Agrelo ao autor, realizada em 5 de março de 2015. Foi Coordenador Geral do Pakapaka até 2016, leciona na UBA e já atuou como consultor em televisão e infância para a Organização de Estados Iberoamericanos, para a televisão pública e ministérios de educação de vários países da América Latina. 
Tabela 2: Origem da programação - Televisão pública e canais privados - Buenos Aires

\begin{tabular}{|c|c|c|c|c|}
\hline \multirow[t]{2}{*}{ Origem da programação } & \multicolumn{2}{|c|}{$\begin{array}{l}\text { Canal } 7 \text { de Buenos Aires } \\
\text { (Televisión Pública) }\end{array}$} & \multicolumn{2}{|c|}{$\begin{array}{c}\text { Canais privados } \\
\text { da grande Buenos Aires }\end{array}$} \\
\hline & 2009 & 2011 & 2009 & 2011 \\
\hline Produção própria & $53 \%$ & $43 \%$ & $26 \%$ & $29 \%$ \\
\hline Produção de terceiros & $19 \%$ & $13 \%$ & $27 \%$ & $23 \%$ \\
\hline Retransmissão & $6 \%$ & $3 \%$ & - & $2 \%$ \\
\hline Produção dos EUA & - & $1 \%$ & $21 \%$ & $12 \%$ \\
\hline Produção da América Latina & & & $10 \%$ & $8 \%$ \\
\hline Produção da Europa & $3 \%$ & $14 \%$ & - & - \\
\hline Repetição & $2 \%$ & $4 \%$ & $8 \%$ & $8 \%$ \\
\hline Coprodução nacional & $16 \%$ & $22 \%$ & $5 \%$ & $10 \%$ \\
\hline
\end{tabular}

Segundo outra entrevista com Agrelo95, a questão da regionalização nessas coproduções partia do pressuposto de que a garantia da representação e diversidade regional de fato não poderia ser feita a partir de Buenos Aires, mas com as próprias regiões. Ele afirmou que a efetivação dessa concepção exigia um processo longo de práticas sistemáticas alinhadas com esse princípio. As táticas do canal estavam ligadas a entender o avanço processual nesses lugares com pouca produção audiovisual: no início, enviavam pessoas da sede do canal, de Buenos Aires, para a região, para gravar o que se desejava da infância do lugar; em seguida, contatavam produtoras da região, buscando construir convênios, enviando os equipamentos e realizando o projeto com pessoas do lugar; depois, a própria produtora gravava o demandado com as pessoas do lugar e enviava o produto; até chegar, finalmente, na situação em que essas produtoras apresentavam propostas próprias do que queriam representar e mostrar.

As chamadas "ações territoriais" do canal também estavam ligadas a essa concepção de televisão articulada com o território. Consistiam em festivais, eventos e outras ações envolvendo personagens e conteúdos do canal nas diferentes regiões do país. Uma das ações de maior visibilidade era o evento Tecnópolis, em Buenos Aires, onde havia ações dos canais educativos. A ausência

95 Entrevista de Facundo Agrelo ao autor, realizada em 15 de dezembro de 2016. 
de dados públicos sobre essas ações impedem a análise de suas lógicas e resultados.

Questões como os diferentes sotaques, hábitos culturais e alimentares e etnias estavam presentes na programação do canal Pakapaka. Os diversos temas articulados à infância de direitos partiam de perspectivas regionais, além de promover um olhar argentino e latino-americano - episódios do programa mencionado na epígrafe, como "La asombrosa excursión de Zamba a la Patria Grande", traziam essa perspectiva, em releitura das narrativas dos colonizadores. Entre os temas das viagens do personagem nesse programa em especial - já abordado por diversos trabalhos acadêmicos (ÁLVAREZ GANDOLFI, 2013; DUEK et al., 2011; LINARE; CUESTA, 2015; MUROLO, 2013) - estão: as excursões à Biblioteca Popular de Clorinda (Formosa), ao Museu das Malvinas, à Casa Rosada, à Amazônia, à Copa do Mundo; viagens à história da Revolução Industrial, à história da comunicação, assim como de eventos e temas históricos latino-americanos como à (batalha de) Vuelta de Obligado, à Conquista da América, à Revolução mexicana, ao bicentenário da Declaração de Independência, à Conquista da América, à Patria Grande e às Culturas PréColombianas; percursos acompanhados por personagens históricos como Juana Azurduy, Simón Bolívar, Martín Fierro, Martín Miguel de Güemes e José Artigas; e apresentando temas e personagens da cultura latino-americana, em excursões com os povos originários, com os músicos, escritores, artistas e trabalhadores latino-americanos, à luta das mulheres latino-americanas e até à Geografia latino-americana (PAKAPAKA, 2015a). Essa abordagem, que nunca havia estado presente na programação televisiva infantil, foi alvo de críticas e questionamentos de setores mais conservadores da sociedade argentina - como visto em diversas matérias publicadas pelos meios hegemônicos (CLARÍN, 2015; LA NACIÓN, 2012b, 2016).

Longe de ter elementos para uma análise conclusiva da experiência do canal, o registro dessa experiência permite trazer à atenção as possibilidades de 
uma política pública, no âmbito do Estado, com concepções de regionalização e promoção de direitos - no caso, para as infâncias -, em promover articulações com agentes nos lugares para ampliar as vozes e representações a partir desses lugares. Ainda que seja uma experiência abreviada nesses princípios e prioridades apresentados nesses cinco anos iniciais do canal, a iniciativa permite vislumbrar o papel central que a comunicação pública pode ter na promoção da diversidade e pluralidade de vozes no território. 


\section{capítulo 5}

Reorientação das políticas de comunicação e realinhamento com os conglomerados midiáticos 


\section{Reorientação das políticas de comunicação e realinhamento com os conglomerados midiáticos}

Os impulsos globais não são homogêneos, são altamente seletivos, $e$ cada vez mais seletivos. Por isso mesmo, esses impulsos, que são os interesses, as corporações transnacionais, os investidores estrangeiros, escolhem muito bem os pontos de modernização.

Ana Clara Torres Ribeiro, Territórios da sociedade, impulsos globais e pensamento analítico (2012b).

'La ley de medios no se toca, por ahora', dijo el ministro de Comunicaciones, Oscar Aguad. Pero se tocará, y será pronto. [...] Los equipos técnicos de Macri se vienen reuniendo con aquellos directivos de empresas desde hace meses.

José Crettaz, no jornal La Nación, 23 de dezembro (2015).

Em 10 de dezembro de 2015, assumiu um novo governo nacional na Argentina, do presidente Mauricio Macri (Cambiemos). A mudança de governo acompanhou um realinhamento das políticas de comunicação e um conjunto de ações voltadas ao desmantelamento de parte do arcabouço institucional, de programas e de aspectos normativos que acompanharam a LSCA, interpretada aqui como evento geográfico. Tal mudança está em diálogo com processos de outras formações socioespaciais latino-americanas, sobre o que trata Segrera (2016) - desde a derrubada de governos eleitos, com forte papel dos poderes midiático e judicial, até o fortalecimento de alternativas eleitorais de políticos alinhados com o discurso neoliberal.

Para além das dinâmicas eleitorais e da política institucional da formação socioespacial argentina, cabe entender aqui como esse novo momento, articulado com uma retomada ou aprofundamento neoliberal (MEDEIROS, 2018), representa um agravamento do poderio das corporações midiáticas hegemônicas, com o reforço do que Agnew e Corbridge chamam de hegemonia do liberalismo transnacional (AGNEW; CORBRIDGE, 1995, p. 164).

Na comunicação, conforme Loreti, Charras e Lozano (2017), as mudanças representam um deslocamento de um paradigma de direitos 
humanos para um modelo de negócios. Como lembra McChesney (2010, p. 218), “a peça principal das políticas neoliberais é, invariavelmente, a reivindicação de desregulamentar a mídia comercial e os mercados de comunicação. Na prática, isso significa que são 're-regulamentados' para servir aos interesses empresariais". Uma das epígrafes deste capítulo, artigo de José Crettaz em defesa da retomada da agenda empresarial na comunicação com Macri, é demonstrativa desse processo.

Serão analisados, aqui, dois eixos dessas transformações, considerando as ações realizadas até o fim de 2017: em primeiro lugar, o conjunto de ações que abrangem desde a sustentação discursiva da necessidade de mudar o paradigma que acompanhou a LSCA até o desmonte normativo e institucional em várias das iniciativas analisadas nos capítulos anteriores; em seguida, consequências ligadas ao crescimento da concentração na mídia, à redução da pluralidade e da diversidade e ao aprofundamento da violência da informação. Nessa análise, partindo do território usado, busca-se identificar as prioridades desse conjunto de ações - o que foi realizado logo no início do governo - e as maiores resistências a esse processo. 


\title{
5.1. Das disputas na psicosfera ao desmonte normativo e institucional
}

\author{
O Estado abandonou sua principal obrigação de manter o mercado \\ competitivo. \\ Argentina (Presidência), informe El Estado del Estado (2016). \\ Acreditamos que o desafio vai ser defender nas ruas tudo o que \\ conquistamos nas ruas. E este é o momento para que todos estejamos \\ nas ruas defendendo essas conquistas. \\ depoimento na manifestação La ley de medios no se toca, de 12/12/2015, \\ disponível em Intervozes (2017a).
}

Por decreto, em dezembro de 2015, o governo Macri estabeleceu mudanças no arcabouço institucional e normativo criado pela LSCA cujo caráter geral implica, segundo Becerra (2017, p. 135), em regressões relativas a direitos que haviam sido reconhecidos pelas regulações anteriores - ainda que muitos desses não houvessem, ainda, se materializado, sobretudo em função da disputa com o Grupo Clarín. Esse novo sentido das políticas de comunicação se baseou na visão da comunicação como modelo de negócios, articulada com a hegemonia do modelo econômico neoliberal. Como será discutido adiante, as primeiras medidas são reveladoras dos interesses atendidos com esse novo sentido das políticas.

Acompanhando esse conjunto de ações, teve destaque a difusão de uma narrativa, com apoio dos grupos midiáticos hegemônicos, sobre a necessidade de transformação do marco normativo das comunicações. Se os meios de comunicação já estavam nessa campanha desde antes da aprovação da LSCA e mantiveram o discurso durante sua judicialização, inaugurou-se uma nova etapa com a eleição do novo governo, realinhado com os interesses dos grandes grupos de mídia. Conforme Moraes (2017, p. 40), na cruzada das corporações midiáticas contra as medidas antimonopolistas, elas têm recorrido a mecanismos de indução ideológica, neutralização do dissenso e desqualificação das posições contrárias. Assim, entre os elementos fundamentais da narrativa 
construída para o desmantelamento do arcabouço normativo na Argentina, estava: (1) a defesa de uma suposta "desideologização" das normas, que estariam marcadas por interesses do governo anterior; (2) a ênfase no modelo de negócios da comunicação, usando a convergência tecnológica como justificativa para as mudanças normativas; e (3) esforços pela ressignificação da "pluralidade" de vozes e do que a promoveria, a partir de uma perspectiva neoliberal.

O primeiro ponto é coerente com a recomposição da hegemonia neoliberal. Como afirmaram Pierre Dardot e Christian Laval (2016, p. 243), “a grande vitória ideológica do neoliberalismo consistiu em 'desideologizar' as políticas seguidas, a ponto de não serem sequer objeto de debate". Assim emerge um consenso neoliberal, com a uniformidade produzida e imposta por diversos meios (MÉSZÁROS, 2004, p. 14). Em geral, "as autoridades políticas que adotam as práticas neoliberais recusam-se a admitir qualquer ideologia. $O$ neoliberalismo, quando inspira políticas concretas, nega-se como ideologia, porque ele é a própria razão" (DARDOT; LAVAL, 2016, p. 242). Essa é a estratégia que marca a profusão de sentidos sobre as políticas de comunicação no território argentino nessa nova etapa. Importante notar que, depois do que Dardot e Laval chamam de etapa militante do neoliberalismo ${ }^{96}$, com a agenda de Thatcher e Reagan nos anos 1980, as propostas neoliberais, já consolidadas no imaginário global, passam a ser consideradas apenas ações de "boa governança", "boas práticas" ou referentes a uma necessária "adaptação à globalização" (DARDOT; LAVAL, 2016, p. 242-243). O governo argentino utiliza a narrativa de uma agenda supostamente desideologizada não só na comunicação ${ }^{97}$. Essa questão se articula com a

96 É importante considerar essas transformações ou etapas do neoliberalismo no bojo de um evento geográfico global de mundialização financeira (CHESNAIS, 1998) que se realiza em diferentes tempos e com distintas resistências nos diferentes territórios. Como lembra Arroyo (1999, p. 15), "a vocação por mundializar as relações econômicas, culturais e políticas é intrínseca ao capitalismo e acompanha-o desde suas origens". Chesnais (1998, p. 24, 1999, p. 25) identifica três momentos principais da difusão desse evento: (1) de 1960 ao final da década seguinte, caracterizado por uma internacionalização financeira limitada, com a adoção do sistema de taxas de câmbio flutuantes; (2) de 1980 a 1985, caracterizado pela expansão da liberalização dos mercados, sobretudo nos países capitalistas centrais; e (3) entre 1986 e 1995, constituindo uma acentuação da interligação dos mercados e incorporação dos chamados "mercados emergentes", caso dos territórios latino-americanos.

97 Natanson (2018, p. 53-76) analisa como essa "ideologia da não-ideologia" fundamenta discursos e ações do governo Macri e de seu partido (PRO). 
tentativa de difusão, no território, de uma psicosfera marcada pelo paradigma administrativo: "a sistematização de valores e de práticas que atualmente traduz os ideais da eficácia, do bom desempenho e do sucesso e, portanto, a conduta racional correspondente à atual fase do capitalismo" (RIBEIRO, 2011b, p. 103). Segundo Ribeiro (2011b, p. 104), o paradigma administrativo representaria um estado de normatividade, apoiado por um consenso passivo, que se distingue radicalmente do consenso político, conforme tradicionalmente concebido, calcado no debate aberto de posições divergentes.

O segundo elemento basilar a essa fundamentação é a convergência tecnológica. O argumento da busca de uma regulação convergente foi usado como argumento para desmontar algumas das disposições normativas mais importantes (LORETI; CHARRAS; LOZANO, 2017, p. 45). Conforme Monje, Rivero e Zanotti (2017, p. 70, tradução nossa) "com a convergência como novo predicado do futuro das comunicações, em pouco menos de um mês, a arquitetura institucional criada pelas normativas anteriores sofreu intervenções em suas áreas centrais e foi dissolvida". Essas mudanças propunham, conforme Bizberge (2018, p. 110, tradução nossa),

um esquema desregulatório que deixava de lado a preocupação com a concentração com base no argumento do avanço tecnológico e da promoção da concorrência. [...] Sob o lema de fomento à concorrência, a discussão sobre a convergência projeta um cenário de flexibilização de regras para os atores de TV paga, ao mesmo tempo em que se intensifica a concentração do sistema de comunicação.

Becerra (2017) chama de "paradoxo da abertura anticoncorrencial" a contradição entre um discurso de promoção de maior concorrência do mercado de comunicação convergente com as ações supostamente para esse fim, que são de flexibilização das exigências aos grandes grupos e derrocada de medidas antimonopolistas.

O imperativo da convergência e a promessa de um marco regulatório convergente marcaram a sustentação discursiva do conjunto de ações para 
reorganização da comunicação no território argentino. Califano (2017, p. 52) afirma que as mudanças eram justificadas pelo governo com uma suposta necessidade de alcançar uma convergência plena entre os setores do audiovisual e de telecomunicações e atingir uma homogeneidade normativa para favorecer a concorrência e promover investimentos. As manifestações públicas e o conteúdo dos primeiros decretos que estabeleceram a nova política de comunicação representam uma interpretação do sistema midiático que, conforme Becerra (2017, p. 137), estaria condicionado pela percepção dos poucos atores dominantes desse mercado, agregando ao discurso de justificativa das transformações doses de 'convergência' - que, por sua vez, seria concebida de modo rudimentar, como mero cruzamento entre as indústrias audiovisual e de telecomunicações.

Por fim, a narrativa construída baseava-se em uma tentativa de ressignificação da pluralidade midiática. Para isso, combinava-se a defesa neoliberal de uma desregulamentação que promoveria a concorrência pelo mercado com acusações de uso político, partidário e ideológico dos meios públicos, das políticas de fomento e de outras iniciativas no marco da LSCA.

Uma ilustração da narrativa difundida para dar suporte às mudanças nas políticas de comunicação é o conteúdo do informe "El Estado del Estado: Diagnóstico de la Administración Pública a diciembre de 2015" (ARGENTINA, 2016), publicado pela Presidência argentina em junho de 2016 - meses depois de várias das medidas de desmonte normativo e institucional. Na seção chamada Comunicação e Mídia (ARGENTINA, 2016, p. 177-198), o texto inicia com uma análise do mercado de telecomunicações, que recebe grande ênfase - a aproximação da agenda das telecomunicações com o audiovisual é, de modo contraditório com o conteúdo de ações instituídas nos decretos, uma estratégia para sustentar o discurso da convergência. Entre os argumentos, o documento defende que a base normativa seria velha, que as instituições dificultavam a convergência tecnológica e critica frequentemente aspectos da burocracia e até da manutenção dos edifícios em que as instituições de controle funcionavam. A 
subseção do documento intitulada Liberdade de expressão e meios públicos foi iniciada com a acusação de que os programas e planos dos diferentes ministérios que tratavam sobre o tema da comunicação configurariam um "maquinário midiático e cultural a serviço da propaganda política" e que "[...] foram reduzidas as capacidades estatais para prover um serviço público de qualidade em termos comunicacionais, culturais e informativos" (ARGENTINA, 2016, p. 187-188, tradução nossa).

A perspectiva do documento é baseada em uma visão de mercado como pode ser visto na epígrafe deste capítulo - sem que houvesse menções à perspectiva do direito à comunicação. Cabe ressaltar, ainda, que o informe não tem um caráter de diagnóstico baseado em dados, sendo mais discursivo e opinativo. Como notam Monje, Rivero e Zanotti (2017, p. 77), ele não remete a fontes verificáveis - denúncias e acusações que são apresentadas não apresentam fontes de informação que sustentem essas acusações de maneira irrefutável.

Como afirma Becerra (2017, p. 139), apesar do discurso de modernização, as mudanças na política de comunicação a partir de dezembro de 2015 têm um caráter conservacionista e restaurador. Cabe, assim, resgatar as principais ações que marcam a reorientação das políticas de comunicação audiovisual na direção da retomada neoliberal, com ênfase no desmonte normativo e institucional de aspectos da LSCA ligados à comunicação ascendente. Merecem uma atenção especial as primeiras medidas tomadas, ainda entre dezembro de 2015 e janeiro de 2016. Essas ações têm como instrumento principal o uso de decretos de "necessidade e urgência" (DNUs) - o que revela a centralidade do tema para a agenda do novo governo, já que várias das ações poderiam ser tomadas por resoluções dos órgãos de aplicação existentes ou ser encaminhadas como mudanças legais a serem amplamente discutidas e consensuadas.

Uma das primeiras medidas dizia respeito à autoridade de aplicação da LSCA, a AFSCA. O governo decretou uma intervenção na instituição, para 
substituir seu diretório diretivo. Também interviu na AFTIC, autoridade de aplicação da lei Argentina Digital, de telecomunicações. Como visto anteriormente, a AFSCA possuía um órgão colegiado de gestão onde o poder executivo não tinha maioria automática - indicava dois dos sete membros, que incluíam, ainda, diferentes grupos do Congresso Nacional e participação da sociedade civil organizada. Os mandatos dos diretores perdurariam até o fim de 2017. Após determinar a intervenção nos dois órgãos no dia 22 de dezembro de 2015 (ARGENTINA, 2015a), uma semana depois, um novo decreto (ARGENTINA, 2015b) acabou com as autoridades regulatórias do audiovisual e das telecomunicações e as substituiu por um novo órgão dependente do Poder Executivo, o Ente Nacional de Comunicações (Enacom) (BECERRA, 2017, p. 135). No Enacom, quatro dos sete membros eram indicados pelo governo e qualquer dos integrantes podia ser destituído pelo presidente sem justificativa. Outras institucionalidades de participação popular estabelecidas pela LSCA foram extintas e o que foi mantido, ficou com funcionamento precário (MONJE; RIVERO; ZANOTTI, 2017, p. 70). O Conselho Federal de Comunicação Audiovisual (Cofeca) foi dissolvido por decreto e o conselho anunciado para seu lugar não foi estabelecido ou nomeado.

Outra ação do novo governo foi a modificação dos aspectos normativos mais estratégicos aos conglomerados midiáticos: as barreiras à concentração monopólica (Quadro 12). Os limites de propriedade de licenças da TV aberta e rádio foram flexibilizados, a transferência de licenças entre operadores foi permitida e as licenças anda tiveram suas durações estendidas e foram renovadas. A maioria das medidas do decreto n. 267/2015, do fim de dezembro de 2015, se referem à extensão das licenças atuais e à eliminação de obstáculos para a concentração, ainda maior, do mercado audiovisual (BECERRA, 2017, p. 137). Uma das dimensões dessa flexibilização foi a mudança de enquadramento normativo da televisão a cabo por assinatura de serviços audiovisuais para serviços de telecomunicações - sobre os quais não incidem 
mais as regras audiovisuais, como de diversidade, regionalização e outras. Essa perspectiva é contrária ao direito comparado e a recomendações internacionais de proteção à diversidade, produção local, pluralismo e equilíbrio (LORETI; CHARRAS; LOZANO, 2017, p. 54).

Quadro 12: Principais mudanças normativas na LSCA por meio dos decretos de dez/2015

\begin{tabular}{|c|c|c|}
\hline & LSCA antes dos decretos & LSCA após decretos \\
\hline Serviços regulados & $\begin{array}{l}\text { Radiodifusão, TV via satélite, TV a cabo } \\
\text { por assinatura }\end{array}$ & Radiodifusão, TV via satélite \\
\hline \multirow[t]{2}{*}{$\begin{array}{l}\text { Limites à } \\
\text { concentração }\end{array}$} & $\begin{array}{l}\text { Nacional: } 1 \text { licença via satélite, } 10 \text { licenças } \\
\text { de radiodifusão (TV aberta ou rádio), } 24 \\
\text { de televisão por assinatura a cabo - com } \\
\text { máx. de 35\% dos habitantes/assinantes; } \\
\text { proibição de propriedade cruzada. }\end{array}$ & $\begin{array}{l}\text { Nacional: } 1 \text { licença via satélite, } \mathbf{1 5} \\
\text { licenças de radiodifusão (TV aberta ou } \\
\text { rádio), sem limitações de propriedade } \\
\text { cruzada. Televisão paga a cabo: sem } \\
\text { limites de concentração. }\end{array}$ \\
\hline & $\begin{array}{l}\text { Local: } 1 \text { licença AM; } 1 \text { FM ou até } 2 \text { licenças } \\
\text { quando houver mais de } 8 \text { na área; } \\
1 \text { de televisão por assinatura ou } 1 \text { de } \\
\text { radiodifusão televisiva aberta. } \\
\text { Total máximo: } 3 \text { licenças. }\end{array}$ & $\begin{array}{l}\text { Local: } 1 \text { licença AM; } 1 \text { FM ou até } 2 \text { licenças } \\
\text { quando houver mais de } 8 \text { na área; } 1 \text { de } \\
\text { radiodifusão televisiva aberta. Sem } \\
\text { limites à televisão paga a cabo. } \\
\text { Total máximo: } 4 \text { licenças. }\end{array}$ \\
\hline $\begin{array}{l}\text { Transferência de } \\
\text { licenças }\end{array}$ & $\begin{array}{l}\text { Proibidas. Há regras para troca de sócios } \\
\text { dos meios comerciais. }\end{array}$ & $\begin{array}{l}\text { Liberadas (exceto para sem fins } \\
\text { lucrativos), sem exigência de autorização }\end{array}$ \\
\hline Prazo e renovação & $\begin{array}{l}10 \text { anos desde a expedição, renováveis } \\
\text { por uma vez (processo } 18 \text { meses antes, } \\
\text { contando com audiências públicas) }\end{array}$ & $\begin{array}{l}\text { Todas as licenças foram renovadas por } \\
\text { decreto até } 2026 \text {, com prorrogação de } \\
\text { mais } 5 \text { anos. }\end{array}$ \\
\hline $\begin{array}{l}\text { Instituição de } \\
\text { aplicação da lei }\end{array}$ & $\begin{array}{l}\text { AFSCA (para LSCA; AFTIC para } \\
\text { Argentina Digital) }\end{array}$ & Enacom \\
\hline $\begin{array}{l}\text { Controle social sobre } \\
\text { as instituições de } \\
\text { aplicação }\end{array}$ & $\begin{array}{l}\text { Colegiados eleitos, com mandato que } \\
\text { perpassava a gestão presidencial. } \\
\text { Participação da sociedade civil e das } \\
\text { minorias do congresso. Na AFSCA, } \\
\text { governo indicava } 2 \text { de } 7 \text { membros. }\end{array}$ & $\begin{array}{l}\text { Governo com maioria a priori (indica } 4 \\
\text { de } 7 \text { membros). Participação das } \\
\text { minorias do congresso. Membros podem } \\
\text { ser retirados pelo Presidente sem } \\
\text { justificativa. }\end{array}$ \\
\hline
\end{tabular}

Elaboração própria. Fontes: Argentina (2009c, 2015a, b).

Essas transformações normativas apontadas no Quadro 12 foram intervenções precisas para atender demandas dos conglomerados - atingiram, por exemplo, os pontos nevrálgicos da disputa anterior com o Grupo Clarín, que passou a não estar mais violando os limites de concentração. Segundo Becerra (2017, p. 136, tradução nossa), "os diretamente beneficiados são os grupos audiovisuais maiores (Clarín é o mais visível, mas não é o único)". Percebe-se que os novos limites adéquam a lei aos grandes meios, ao invés de adequar os grupos 
concentrados à lei, como normatizava a LSCA anteriormente (BECERRA, 2017, p. 149). A retirada da televisão a cabo do enquadramento normativo do audiovisual é especialmente grave em função das características de consumo televisivo na formação socioespacial argentina, com grande predomínio desse serviço.

Outros pontos de destaque são as mudanças de flexibilização das renovações e transferências de licenças, mudando da lógica de um acompanhamento da sociedade em função do interesse público das concessões para uma lógica de garantia de estabilidade de investimentos aos meios privados e de perpetuação de licenças ou apropriação privada do espectro radioelétrico. A partir dessas mudanças, o Enacom arquivou, em sua primeira reunião (LORETI; CHARRAS; LOZANO, 2017, p. 51), todos os pedidos de adequação. Seu presidente, Miguel de Godoy, afirmou então: "damos por encerrada uma etapa de pressão com adequações coercitivas, com o objetivo de olhar para frente com outro horizonte. É virar a página de uma etapa muito complicada de coerções às empresas jornalísticas" (CRETTAZ, 2016, tradução nossa). Percebe-se um discurso do Estado alinhado com a defesa do interesse dos grupos de mídia dominantes.

Para orientar as políticas nesse sentido, uma institucionalidade nova foi criada. Ainda em dezembro de 2015, o governo estabeleceu um Ministério das Comunicações (Decreto n. 13/2015), que foi dissolvido em julho de 2017. Durante esse período, o Ministério abrigou o Ente Nacional de Comunicações, a ARSAT e a empresa de correios. Também foi criado o Sistema Federal de Meios e Conteúdos Públicos, subordinado à Chefia de Gabinete de Ministros. Nesse sistema, foram alocadas, entre outras: a empresa pública de rádio e televisão, RTA, responsável pela Televisão Pública Argentina (Canal 7 de Buenos Aires) e pela Rádio Nacional; a agência de notícias Télam; o repositório BACUA; o parque Tecnópolis; a participação do Estado argentino na Telesur; e os canais públicos Pakapaka, Encuentro e DeporTV, até então do Ministério da Educação (MONJE; RIVERO; ZANOTTI, 2017, p. 76).

Outra dimensão transformada das políticas de comunicação aqui 
estudadas foi a lógica da transmissão futebolística. Ainda em 2015, o governo celebrou acordos de exclusividade das partidas mais importantes com canais privados - Canal 13, do Grupo Clarín, América e Telefé (que não estão nacionalmente presentes na TDA) - deixando de chegar essa programação gratuitamente à maioria do território nacional (MARINO, 2017a). Em 2017, o programa Fútbol para Todos foi encerrado e foi retomada a lógica de acesso pago às transmissões do esporte. Conforme Marino (MARINO, 2017a), os direitos sobre as transmissões foram, desta vez, adquiridos por dois conglomerados transnacionais midiáticos: FOX e Turner. A distribuição dos conteúdos e as condições de acesso mudaram (Quadro 13).

Quadro 13: Transmissões do futebol na televisão argentina - direitos, distribuição e condições para acesso (1991-2021)

\begin{tabular}{|c|c|c|c|}
\hline Período & Direitos & Distribuição & Condições para acesso \\
\hline $\begin{array}{l}1991- \\
2009\end{array}$ & $\begin{array}{l}\text { TYC (hoje } \\
\text { Torneo) e } \\
\text { Clarín }\end{array}$ & $\begin{array}{l}\text { Maioria dos jogos exibidos na } \\
\text { assinatura básica. Sistema codificado } \\
\text { para partidas mais importantes. Jogos } \\
\text { de menor relevância na TV aberta. }\end{array}$ & $\begin{array}{l}\text { Pagar o serviço de televisão a cabo e pagar } \\
\text { adicional para jogos mais importantes ("el } \\
\text { partido de la fecha”). }\end{array}$ \\
\hline $\begin{array}{c}2009-- \\
2017\end{array}$ & $\begin{array}{c}\text { Estado } \\
\text { nacional }\end{array}$ & $\begin{array}{l}\text { Todas as partidas eram exibidas por } \\
\text { canais da TV aberta, exceção quando } \\
\text { havia duplicação de partidas no } \\
\text { mesmo horário. Desde 2010, na TDA. }\end{array}$ & $\begin{array}{l}\text { Sem custos para lugares com acesso à TDA. } \\
\text { (Onde não havia cobertura de TV aberta, } \\
\text { seria necessário serviço televisivo pago). }\end{array}$ \\
\hline $\begin{array}{l}2017- \\
\text { atual }\end{array}$ & $\begin{array}{l}\text { Fox Sports } \\
\text { LA e Turner }\end{array}$ & $\begin{array}{l}\text { Todas as partidas em um pacote } \\
\text { específico, pago; desde } 2018 \text { também } \\
\text { em serviço de streaming pago. }\end{array}$ & $\begin{array}{l}\text { Pagar o serviço de televisão a cabo e pagar } \\
\text { pacote específico. Para ver em alta } \\
\text { definição, pagar outro pacote; desde } 2018 \text {, } \\
\text { opção de pagar adicional para streaming. }\end{array}$ \\
\hline
\end{tabular}

É possível observar que, assim como acontecia antes do Fútbol para Todos, agora a mercantilização da comunicação predomina, com a volta da necessidade de pagamento de serviços e pacotes específicos. As novas tecnologias no contexto do audiovisual ampliado foram apropriadas, ainda, para novas oportunidades de ganhos aos grupos midiáticos, com serviços a parte para os que desejam acompanhar as partidas pela internet. A ação faz parte de um redirecionamento das prioridades do Estado na comunicação, com o enfraquecimento da TDA como alternativa ao mercado televisivo pago e com a 
reversão da concepção de que o Estado deveria garantir acesso a diversos conteúdos culturais.

A psicosfera de sustentação à retomada neoliberal na regulação da comunicação acompanha um novo papel do Estado na organização da tecnosfera ligada à circulação de informações no território argentino. No caso da TDA, segundo N. González (2016, p. 3), as ações englobariam o desfinanciamento da infraestrutura e demissões de profissionais do sistema - além da diminuição da oferta de canais e conteúdos e da falta de garantias para meios sem fins lucrativos, que serão analisados adiante. Houve denúncias de trabalhadores de que teriam sido interrompidas obras para instalação de novas antenas transmissoras (de 32 pendentes, teriam sido terminadas apenas 8 ), de que seguiam demitindo trabalhadores e de que teriam suspendido a distribuição de receptores (ENCUENTRO, 2016). Já há evidências de uma mudança da lógica estatal da ARSAT, conforme analisa Del Negro (2016, p. 12-13) - a busca de uma visão mercadológica para os investimentos da ARSAT; o adiamento da construção do satélite ARSAT-3 - com uma posterior parceria com a empresa privada estadunidense Hughes (ALIAGA, 2017) para a construção desse satélite; habilitação de outras empresas estrangeiras para atuarem no território argentino; e a desconsideração do plano de desenvolvimento satelital aprovado como lei (ARGENTINA, 2015c).

Também é a partir dessa perspectiva da comunicação mercantilizada que se decidiu o destino do dividendo digital, as bandas do espectro radioelétrico que deixariam de ser usadas em 2019, com o fim das transmissões analógicas de televisão. Por meio da Resolução n. 10.090 (ENACOM, 2016), o governo permitiu que as empresas radiodifusoras que emitiam televisão analógica na capital do país permanecessem com a banda do espectro para exploração por outras tecnologias (KRAKOWIAK, 2017; OBSERVACOM, 2017).

A promessa de um novo marco regulatório para o cenário de convergência passou a pautar a ação regulatória do governo, ainda que, até o fim 
de 2017, nenhum projeto de lei nesse sentido tivesse sido apresentado pelo poder público. Essa nova regulação convergente seria realizada sob demanda dos agentes dominantes dos mercados, mas é bastante dificultada pelos interesses contraditórios e, em alguns casos, mutuamente excludentes dos grupos dominantes do audiovisual e de telecomunicações (BECERRA, 2017, p. 149).

A mudança de sentido nas políticas de comunicação, conforme Monje, Rivero e Zanotti (2017, p. 78), toma a convergência como forma de retorno do predicado do mercado à definição das políticas públicas de comunicação. Uma das evidências dessa mudança estaria expressa na parceria do governo com a empresa de consultoria global McKinsey \& Company ${ }^{98}$, que assessorou o Ministério das Comunicações no desenho de uma nova política de comunicação (KRAKOWIAK, 2016). Essa e outras empresas globais de consultoria passaram a ter um papel central na definição das políticas e do planejamento territorial na América Latina com a ascensão do neoliberalismo, na década de 1990. Conforme Silva (2005, p. 14095), as consultoras transnacionais se fortaleceram nas últimas décadas e "conformam hegemônicos sistemas de ações do atual período. Desde a década de 1970 as ações globalizadas das firmas de consultoria impulsionam, entre outros, a difusão mundial de novos paradigmas produtivos com base nas tecnologias da informação". Essas empresas foram fundamentais para as privatizações de empresas públicas em diversos países, auxiliando estrategicamente os governos e promovendo usos corporativos do território (SANTOS, 2009b).

Se, por um lado, as mudanças realizadas logo no início do governo são um indicador do que era estratégico e incomodava interesses agora

98 Segundo Teixeira (2013, p. 89-90), “a McKinsey \& Company nasceu em 1926 nos Estados Unidos e desde então se consolidou como uma das maiores empresas corporativas do mundo. Com mais de 90 escritórios em mais de 50 países essa empresa é contratada pelas maiores corporações de negócios do planeta. Segundo a Revista Fortune, a consultora presta serviço a dois terços das maiores corporações mundiais, sem falar de assessoria à governos, como o brasileiro, que contrata seus serviços para assessorar privatizações e concessões além de oferecer lugar de destaque a empresa na condução de projetos governamentais. Segundo o site Glassdoor, especializado em pesquisas e análises de grandes corporações, o poder dessa empresa pode ser evidenciado pelo salário de seus consultores que variam entre \$120.000 à \$ 160.000". 
representados no novo governo, também é necessário notar que as mudanças normativas e institucionais acompanham resistências de diversas expressões no território argentino (Quadro 14).

\section{Quadro 14: Cronologia das principais transformações normativas à comunicação audiovisual e alguns marcos da resistência - seis primeiros meses do governo Mauricio Macri}

\begin{tabular}{|c|c|c|}
\hline Data & Publicação das principais normas & Alguns marcos da resistência \\
\hline \multirow{4}{*}{$\begin{array}{l}\text { Dezembro } \\
\text { de } 2015\end{array}$} & $\begin{array}{l}\text { 11/12: Decretos 12/2015 - cria o Sistema } \\
\text { Federal de Meios e Conteúdos Públicos } \\
\text { (SFMCP), e 13/2015 - Min. de Comunicações. }\end{array}$ & $\begin{array}{l}\text { 11/12: Início das manifestações públicas, marchas } \\
\text { e protestos em diferentes cidades de todo o país - } \\
\text { La ley de medios no se toca. }\end{array}$ \\
\hline & \multirow{2}{*}{$\begin{array}{l}\text { 21/12: Res. n. } 1 \text { Min. Comunicações: } \\
\text { transfere } 98 \% \text { da ARSAT ao ministério. } \\
\text { 22/12: Decreto 237/2015: Transferência de } \\
\text { meios ao SFMCP. }\end{array}$} & $\begin{array}{l}\text { 23/12: Atos em frente à AFSCA e em outros lugares } \\
\text { em defesa da instituição de aplicação da lei, } \\
\text { contrários à intervenção. }\end{array}$ \\
\hline & & \multirow{2}{*}{$\begin{array}{l}\text { 30/12: Apresentação da primeira liminar (de } \\
\text { várias) para barrar os decretos - sem sucesso. }\end{array}$} \\
\hline & 23/12: Decreto 236/2015: intervenção AFSCA. & \\
\hline $\begin{array}{l}\text { Janeiro } \\
\text { de } 2016\end{array}$ & $\begin{array}{l}\text { 04/01: Decreto 267/2015: Criação do Enacom } \\
\text { e mudanças na LSCA. }\end{array}$ & $\begin{array}{l}\text { 25/ol: Campanha em defesa da LSCA - Coalizão } \\
\text { por uma Comunicação Democrática (CCD). }\end{array}$ \\
\hline \multirow{2}{*}{$\begin{array}{l}\text { Fevereiro } \\
\text { de } 2016\end{array}$} & & $\begin{array}{l}\text { 18/02: Resolução da Defensoría del Público com } \\
\text { resoluções contrárias às mudanças na LSCA. }\end{array}$ \\
\hline & & 20/02: Encontro ComunicAcción, ligado à CCD. \\
\hline $\begin{array}{l}\text { Março } \\
\text { de } 2016\end{array}$ & $\begin{array}{l}\text { 11/03: Conformação da Comissão Redatora } \\
\text { da Lei de Comunicação Convergente. }\end{array}$ & $\begin{array}{l}\text { 03/03: Apresentação pública dos novos } 21 \text { pontos } \\
\text { para a comunicação democrática, da CCD. }\end{array}$ \\
\hline \multirow{3}{*}{$\begin{array}{c}\text { Abril } \\
\text { de } 2016\end{array}$} & $\begin{array}{l}\text { 06/04: Câmera de Deputados ratifica os } \\
\text { decretos 13/2015 e 267/2015. }\end{array}$ & \multirow{2}{*}{$\begin{array}{l}\text { 08/04: Audiência perante a Comissão } \\
\text { Interamericana de Direitos Humanos (CIDH) } \\
\text { sobre os decretos e a liberdade de expressão. }\end{array}$} \\
\hline & \multirow{2}{*}{$\begin{array}{l}\text { 08/04: Câmara de Deputados valida } \\
\text { atribuições do Enacom. }\end{array}$} & \\
\hline & & $\begin{array}{l}\text { 18/04: Jornada cultural das redes de comunicação } \\
\text { popular pela habilitação dos canais digitais } \\
\text { outorgados e em defesa dos } 33 \% \text { do espectro. }\end{array}$ \\
\hline $\begin{array}{l}\text { Junho } \\
\text { de } 2016\end{array}$ & $\begin{array}{l}\text { 07/06: Anúncio: retirada da Telesur da TDA } \\
\text { o9/06: Anúncio: retirada da RT da TDA. }\end{array}$ & $\begin{array}{l}\text { 08/06: Marcha dos trabalhadores da imprensa por } \\
\text { suas fontes de trabalho. }\end{array}$ \\
\hline
\end{tabular}

Elaboração própria. Fonte: Monje, Rivero e Zanotti (2017), CCD

Como é possível observar, as intervenções acompanharam protestos, articulação de redes e organizações para lutar em defesa do direito à comunicação. Isso indica, além do grau de organização popular na formação socioespacial argentina, a presença do tema do direito humano à comunicação e da luta contra a monopolização midiática no imaginário que fundamenta as lutas sociais no país. Simbólico desse processo é o fato de que a primeira marcha de setores populares contra o governo de Mauricio Macri (TELESUR, 2018) tenha 


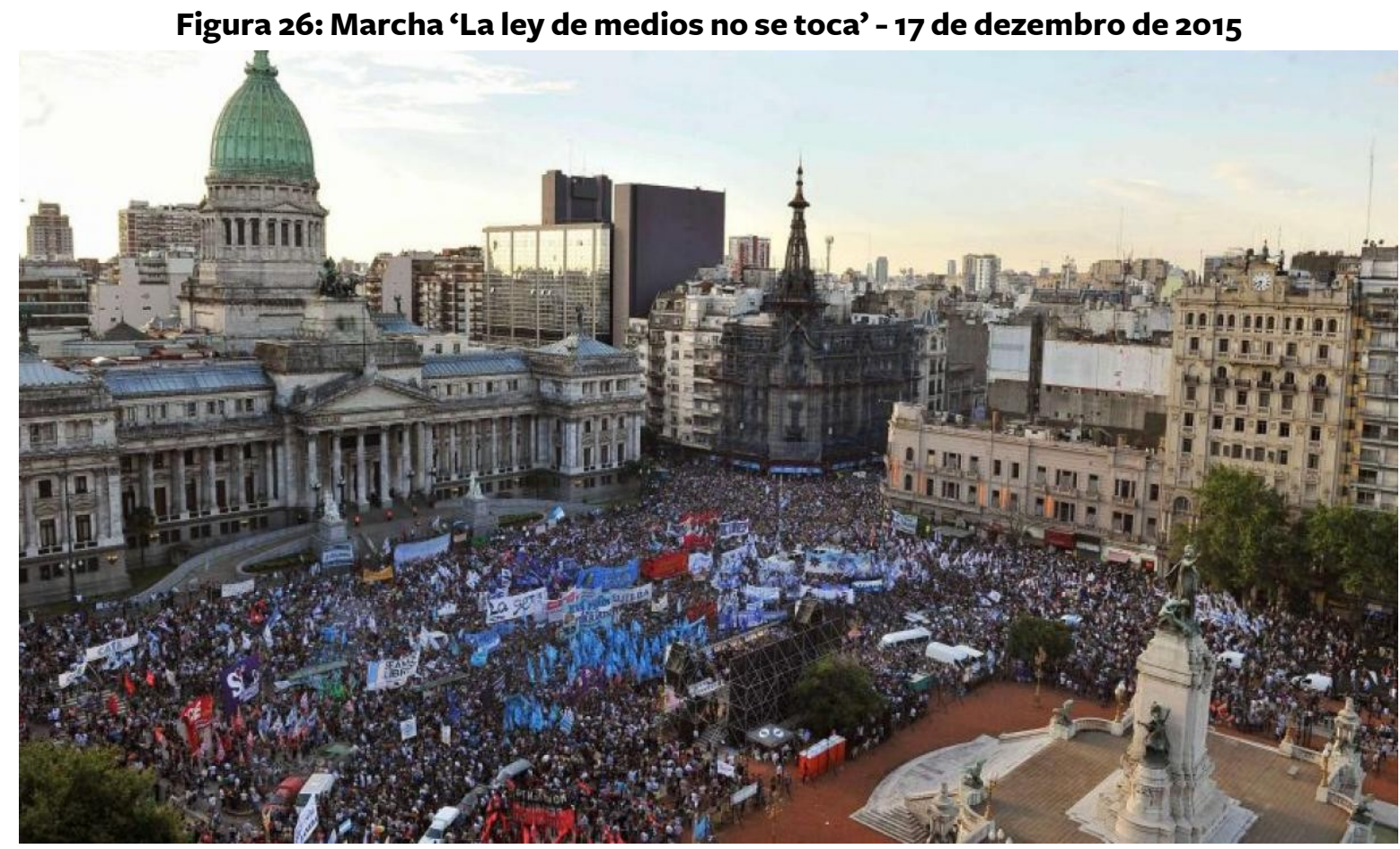

Foto da Agência EFE, em Telesur (2018).

Vários dos marcos da resistência ao desmonte da LSCA citados seguiram a defesa de condições para a pluralidade e diversidade de vozes no território argentino. A Resolução n. 21/2016 da Defensoria do Público de Serviços de Comunicação Audiovisual (OTTAVIANO, 2016) é representativa desses reclamos, reunindo denúncias de todo o território - indígenas, campesinos, trabalhadores e trabalhadoras, redes e coalizões em defesa da comunicação democrática, coletivos que atuam na defesa da igualdade de gênero, comunicadores populares e tantos outros agentes - contra os decretos que desfiguravam a LSCA. Um conjunto de agentes e organizações da sociedade civil99 demandou, no início de 2016, uma audiência perante a Comissão

99 São elas: Centro de Estudios Legales y Sociales (CELS), Asociación Mundial de Radios Comunitarias (Amarc), Universidad Nacional de Lanús (UNLa), Universidad Nacional de las Artes (UNA), Carrera de Ciencias de la Comunicación, Universidad de Buenos Aires (UBA), Red de Carreras de Comunicación Social y Periodismo de Argentina (REDCOM), Foro Argentino de Radios Comunitarias (FARCO), Asociación Latinoamericana de Educación Radiofónica (ALER), Red de Radios Universitarias de América Latina y el Caribe (RRULAC), Asociación de Radiodifusoras Universitarias Nacionales Argentinas (ARUNA), Sistema Integrado de Radios de la Universidad Nacional de Entre Ríos (UNER), Trayecto de locución (Convenio AFSCA UNER), Sindicato Argentino de Televisión (SATSAID), Coalición por una Comunicación Democrática (CCD), Músicos autoconvocados, Instituto Movilizador de Fondos Cooperativos, Red Par e ARBIA (Asociación de 
Interamericana de Direitos Humanos (CIDH) para apontar os danos à liberdade de expressão e ao direito à comunicação das medidas tomadas por decreto, tendo conseguido agendar uma audiência para a sede da Comissão em Washington (EUA) em 8 de abril, onde apresentaram as críticas às medidas unilaterais dos decretos (LORETI; CHARRAS; LOZANO, 2017, p. 57-59). O governo conseguiu que o Congresso Nacional validasse os decretos antes dessa data e apresentou essa justificativa, junto da promessa de um novo marco regulatório das comunicações convergentes. A CIDH, em seu comunicado após o período de sessões (OEA, 2016a, p. 6), valorizou a participação da sociedade civil e o anúncio do governo de que abriria um debate para uma nova lei da convergência, e reforçou o princípio de não regressividade dos direitos humanos, pelo qual afirmou que seguiria acompanhando o caso. 


\subsection{O aprofundamento da violência da informação e a negação da pluralidade}

As forças que impulsionam a convergência provavelmente levarão ao surgimento de "supercompetidores". Esse punhado de atores globais converge para modelos de negócios similares que unirão conteúdo, comércio, publicidade, comunicação e recursos financeiros... buscando garantir o controle exclusivo de cada aspecto de seu relacionamento com o consumidor.

Empresa de consultoria PWC. Perspectives from the Global Entertainment \& Media Outlook 2018-2022 (2018).

O objetivo visado por cada um dos titãs da comunicação é tornar-se o interlocutor único do cidadão. Querem poder proporcionar-lhe afinal notícias, dados, lazer, cultura, serviços profissionais, informações financeiras econômicas; e desta forma colocá-lo em conexão com todos os meios de comunicação disponíveis.

Ignacio Ramonet, A tirania da comunicação (2010).

Ainda que o processo de mudança das políticas de comunicação seja bastante recente, já é possível observar algumas novas tendências a partir de dois campos da agenda da democratização da comunicação, conforme problematizado no capítulo 2: o combate à violência da informação e a promoção de novos agentes comunicacionais. $\mathrm{O}$ exame das ações até aqui indicam um ciclo regressivo, já que apontam para o aprofundamento da violência da informação e para a degradação das condições impulsionadas para a promoção de pluralidade e diversidade de vozes nos lugares. Como afirmam Becerra e Mastrini (2018, p. 6, tradução nossa), "se abandonou o discurso da democratização da mídia, que foi substituído pelo desenvolvimento do mercado e necessidade de atração de investimentos". Serão analisadas, aqui, algumas das dimensões principais desse realinhamento do conjunto de ações no marco das políticas de comunicação.

A reversão dos limites à concentração de propriedade, a flexibilização das regras para as licenças audiovisuais e a retirada dos serviços predominantes de televisão (pagos) da regulação audiovisual são alguns dos elementos cruciais à criação de condições para um aprofundamento da violência da informação. Em primeiro lugar, partindo da economia política da comunicação, Becerra (2017, p. 
137) lembra que, no território argentino, esse mercado é assimétrico e a convergência, resultado do domínio dos quatro grandes operadores do setor, também promoverá assimetria se não for mediada por políticas públicas corretivas. No entanto, como visto, as medidas impostas por decreto vão em outra direção, eliminando obstáculos à concentração. Assim, a concepção que fundamenta as mudanças por decreto acompanha uma lógica de mercado anticoncorrencial e promotora de concentração pois, conforme o autor (BECERRA, 2017, p. 141): (1) ao prorrogar licenças, impede a abertura de concursos que possibilitariam a entrada de novos agentes por vias legais; (2) ao eliminar quase todos os obstáculos à concentração de mercado pela lei audiovisual, conduz a uma maior concentração; (3) ao ignorar efeitos da concentração em inibir a concorrência, contradiz regulação internacional; (4) acompanha uma tendência de superconcentração danosa aos usuários dos serviços na relação entre preços e qualidade; e (5) sinaliza ao setor a existência de uma política orientada a proteger os agentes dominantes de concorrência de novos atores.

Conforme Martínez (2001, p. 39), os monopólios da comunicação representam um atentado contra a democracia. Para além de uma ótica concorrencial do mercado, os danos da concentração da propriedade da mídia para a efetivação do direito à comunicação são bastante graves e alguns deles já foram discutidos neste trabalho. Entre esses danos podem ser citados: redução das fontes informativas; relativa homogeneização de gêneros e formatos; unificação da linha editorial em temas sensíveis; resistência dos grupos mais concentrados a desempenhar funções de serviço público; conflitos de interesse de grupos que possuem outros investimentos nos demais mercados; desenvolvimento de um sistema de apropriação de direitos exclusivos no espetáculo ou esportes; centralização geográfica da programação e da produção de conteúdos; e ambiente de autocensura dos trabalhadores (BECERRA, 2017, p. 147). Todos apontam para a redução da pluralidade e diversidade cultural e regional na comunicação e para a predominância dos círculos de informações 
descendentes (SILVA, 2010).

A acentuação da concentração midiática se concretizou rapidamente na Argentina. Nessa nova etapa, a Fintech - empresa financeira do empresário mexicano David Martínez, sócio da Cablevisión, com o Clarín - tomou o controle da Telecom Argentina, uma das líderes do mercado de telecomunicações (3). Com autorização do Enacom, o Grupo Clarín, após adquirir a Nextel Argentina - que vinha comprando empresas com licenças para operação do espectro radioelétrico - atingiu o auge de concentração nas comunicações no país com sua fusão com a Telecom.

Tabela 3: Assinantes estimados de serviços de comunicação na Argentina - 2017

\begin{tabular}{|c|c|c|c|c|c|c|c|}
\hline \multicolumn{3}{|c|}{ Grupo de comunicação } & \multirow{2}{*}{ TV Paga } & \multicolumn{2}{|c|}{ Internet banda larga } & \multicolumn{2}{|c|}{ Telefonia } \\
\hline Empresa & Grupo & País & & Fixa & Móvel & Fixa & Móvel \\
\hline Cablevisión & Clarín & Argentina & 3.386 .000 & 2.180 .200 & & 19.600 & \\
\hline Telecom & Fintech & México/EUA & & 1.844 .000 & 5.500 .000 & 3.909 .470 & 14.014 .000 \\
\hline Nextel & Clarín & Argentina & & & & & 766.650 \\
\hline Telefónica & Telefónica & Espanha & & 1.880 .000 & 4.400 .000 & 4.137.200 & 16.365 .470 \\
\hline Claro & America Móvil & México & & 48.800 & 4.000 .000 & 286.930 & 17.715 .000 \\
\hline DirecTV & AT\&T & EUA & 2.651 .700 & & & & \\
\hline Telecentro & Telecentro & Argentina & 569.600 & 390.000 & & 200.000 & \\
\hline Outros & & & 2.184 .150 & 685.060 & & 1.058 .250 & 27.000 \\
\hline Total & & & 8.791 .450 & 7.028 .060 & 13.900 .000 & 9.611 .450 & 48.888 .120 \\
\hline
\end{tabular}

Com a fusão de Cablevisión, Nextel e Telecom sob o comando do Grupo Clarín, o mercado teria um operador com possibilidade de atuar em todos os serviços - televisão paga, internet fixa e móvel e telefonia fixa e móvel - em posição de comando (3). Esse é um produto da flexibilidade criada sob o argumento da convergência, permitindo que um grupo concentre o comando de diversos mercados no contexto convergente. Conforme Becerra e Mastrini (2018), as novas possibilidades da convergência são tão seletivas que somente os grupos que dominam $70 \%$ do lucrativo mercado de televisão paga poderiam aproveitar 
integralmente. Para esses autores,

a fusão entre Clarín e Telecom, onde o grupo [Clarín] passa a deter o controle operacional, é a cereja do bolo. [...] o Enacom já autorizou a operação que indica que o Grupo Clarín passa a dominar, a nível nacional, 42\% da telefonia fixa, 34\% da telefonia móvel, $56 \%$ das conexões à Internet banda larga, 35\% da conectividade móvel e $40 \%$ da televisão paga. Ninguém dispõe de um poder de mercado similar (BECERRA; MASTRINI, 2018, p. 10).

Conforme Monje, Rivero e Zanotti (2017, p. 92), o Enacom também autorizou a Cablevisión (do Grupo Clarín) a prestar serviço de telefonia fixa. Segundo os autores, essas operações, agora autorizadas, haviam sido negadas por resoluções das autoridades federais recentemente suprimidas. $O$ principal beneficiário do processo é o Grupo Clarín - desapareceram os limites à sua expansão, foi facilitado o acesso a novos mercados e se regulou de forma assimétrica outros grupos grandes ${ }^{100}$, de forma a pavimentar sua entrada nas telecomunicações (BECERRA; MASTRINI, 2018).

Além da concentração, essa reconfiguração das políticas de comunicação na Argentina acompanhou a permanência e intensificação da internacionalização no setor. Se um dos competidores estrangeiros do Clarín, a espanhola Telefónica, reduziu seu papel no mercado, foi através da entrada de outro estrangeiro: o conglomerado estadunidense Viacom comprou da Telefónica a Telefe, em 2016, por 345 milhões de dólares (TELEFE, 2016). O grupo Albavisión, baseado no México, também ampliou sua participação no mercado de comunicação, assim como Fox e Turner, que ingressaram no mercado de transmissões de futebol (BECERRA; MASTRINI, 2018).

Se, por um lado, o poder e a expressão dos agentes hegemônicos se ampliaram e se consolidaram, por outro a pluralidade também foi reduzida pelo reordenamento e desmantelamento das políticas de comunicação voltadas à

100 Conforme Becerra e Mastrini (2018), até o fim de 2017, as empresas de telefonia não estavam autorizadas a oferecer serviços de televisão satelital nem a utilizar a infraestrutura de operadores pequenos, o que representava assimetrias regulatórias vantajosas ao Grupo Clarín. 
regionalização da produção audiovisual, à promoção de condições técnicas e normativas nos espaços silenciados e ao acesso a condições de financiamento.

Além do desinvestimento na TDA como possibilidade de acesso à televisão gratuita e como infraestrutura de acesso ao audiovisual alternativa à controlada pelos conglomerados midiáticos, o governo encerrou as políticas de fomento à produção de conteúdos para a TDA e de circulação desses produtos os concursos, o Programa Polos Audiovisuais Tecnológicos, o CDA e o BACUA. A plataforma de vídeo sob demanda CDA foi retirada do ar, e o site do BACUA foi substituído por um arquivo com uma lista dos programas produzidos. Como as produções estavam registradas e licenciadas pelo Estado, o repositório ficou inoperante e abandonou a circulação de seus conteúdos. A plataforma de vídeo sob demanda Odeón, que reunia os conteúdos cinematográficos do INCAA com o conteúdo do BACUA e CDA também foi encerrada e substituída pela plataforma Cine.ar, que não conta com os conteúdos produzidos para a televisão digital.

A circulação do audiovisual produzido regionalmente foi, assim, reduzida. Recuos na pluralidade e diversidade de conteúdos também marcaram as ações na grade de programação da TDA (GONZÁLEZ, 2017). Foram retirados os canais Telesur, multiestatal baseado na Venezuela, do qual o Estado argentino era sócio, e o russo RT (RussiaToday) - que voltou ao ar após negociação com o governo do país (RT, 2016). A reprivatização das transmissões de futebol também representou a retirada de conteúdos que eram apreciados e estratégicos para a audiência da televisão pública e para a TDA, como visto anteriormente.

Na comunicação comunitária, Longo et al. (2017, p. 39, tradução nossa) avaliam que "entre 2009 e 2015, as políticas voltadas para o setor de meios sem fins lucrativos foram orientadas - com seus atrasos e problemas - para sua legalização e fomento. As políticas do atual governo [Macri] restauram as perseguições às rádios em situação de ilegalidade forçada, mesmo sem alterar o marco legal". Conforme Natalia Vinelli (2017a) em entrevista, as relações com o 
Enacom para o cumprimento dos direitos dos meios comunitários, alternativos e populares foram tensas. Desde dezembro de 2015, foram suspensos os pagamentos dos concursos do FOMECA, sob a justificativa de uma auditoria. Foram muitos os protestos (27) dos meios comunitários, desde o início do novo governo, em defesa das garantias conquistadas na LSCA, como a outorga de licenças de concursos realizados, o pagamento dos concursos FOMECA já finalizados e a abertura de novos concursos de outorgas e de fomento.

\section{Figura 27: Protesto em frente ao ENACOM pelo pagamento do fundo de fomento à comunicação comunitária - julho de 2016}

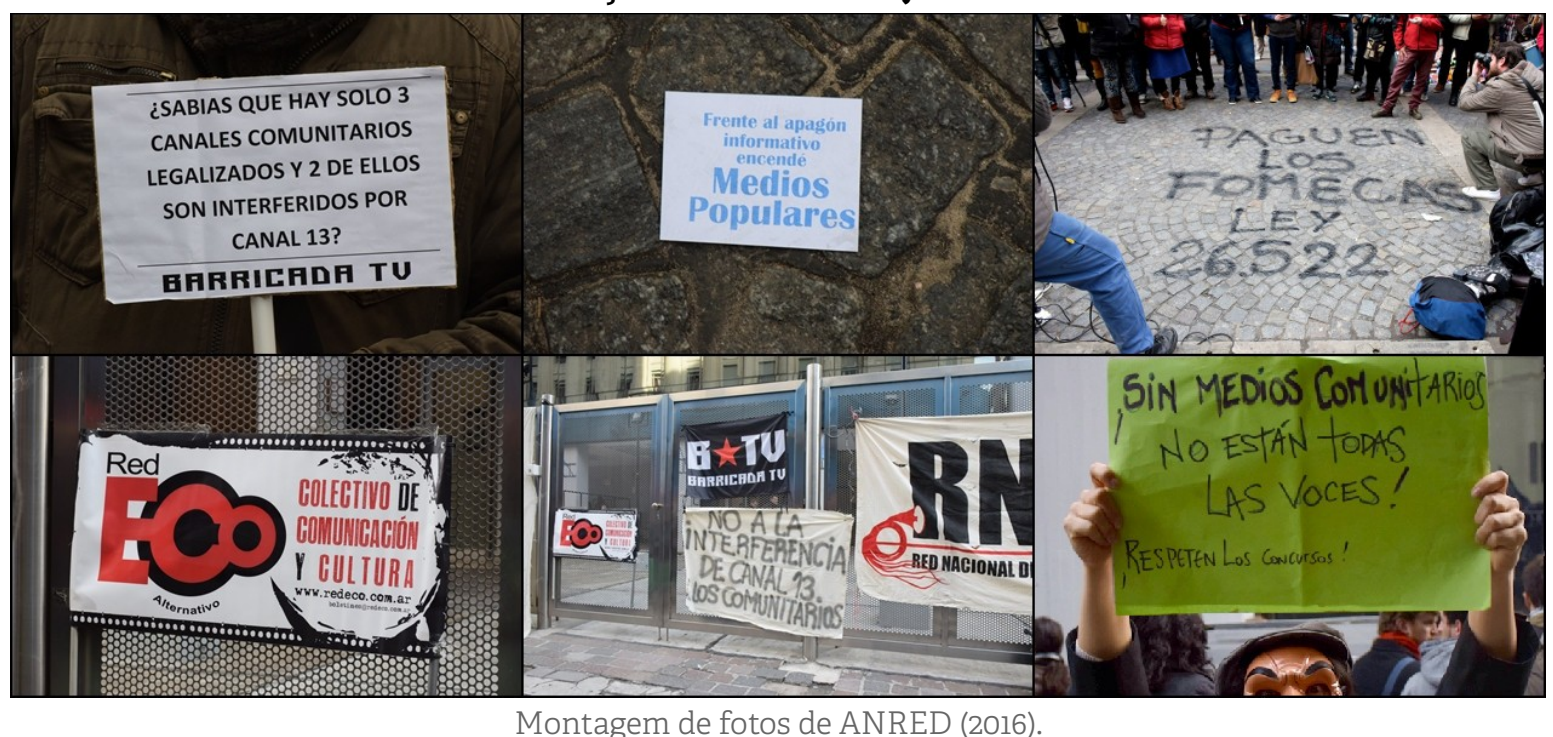

Após diversas mobilizações, o Enacom iniciou o pagamento de recursos atrasados do FOMECA e abriu uma linha de financiamento em 2016, mantendo o fundo em 2017. Conforme Vinelli (2017b, p. 16, tradução nossa),

esta chamada foi conquistada após numerosas mobilizações na sede do organismo [Enacom], e de uma campanha nacional por parte de InterRedes que denunciou o congelamento dos pagamentos e a falta de interesse das novas autoridades em avançar no plano de fomento, o cancelamento da dívida e, consequentemente, seu desentendimento do setor como ator de direito dentro do mapa da comunicação.

Vale lembrar que o Estado, historicamente, além de financiar a comunicação pública e estatal, privilegia o setor privado comercial (LINARES et 
al., 2017) com financiamento direto e indireto, subsídios, isenções de impostos, ampliação de prazos de licenças, facilidades de transferência e renovação, autorização para fusões, renegociação de dívidas, entre outras medidas - criando grande desequilíbrio com o setor comunitário que foi perseguido ou, no melhor dos casos, ignorado (LONGO et al., 2017, p. 49). Vinelli (2017a) ressalta que esse padrão de tratamento desigual é exercido no acompanhamento das contas e o financiamento dos meios sem fins lucrativos pelo Enacom. Segundo a autora, a paralisação do financiamento e os atrasos para o pagamento, com a inflação elevada no período, geram abandono de projetos, atingindo ainda mais as rádios do setor sem fins lucrativos. Para Longo et al. (2017, p. 49, tradução nossa), a partir de dezembro de 2015 são evidentes os retrocessos em relação aos ganhos do período entre 2009 e 2015, com uma diferença: "agora as emissoras do setor social são reconhecidas legalmente e o Estado tem a obrigação de arbitrar os mecanismos necessários para que acessem suas licenças, ao invés de persegui-las como 'clandestinas'". As autoras identificaram três etapas das políticas para a comunicação comunitária (Quadro 15): etapa de ilegalidade (1980-2009), de legalização (2009-2015) e de regressão (2015-2017).

Quadro 15: Dinâmicas principais das políticas de comunicação para meios sem fins lucrativos e comunicação alternativa, popular e comunitária na Argentina (1980-2017)

\begin{tabular}{|c|c|c|c|}
\hline \multirow{2}{*}{ Dimensão } & \multicolumn{3}{|c|}{ Etapa } \\
\hline & Ilegalidade (1980-2009) & Legalização (2009-2015) & Regressão (2015-2017) \\
\hline Marco normativo & $\begin{array}{l}\text { Decreto-lei n. 22.285/1980 } \\
\text { (da ditadura militar) }\end{array}$ & $\begin{array}{c}\text { LSCA } \\
\text { (Lei n. 26.522/2009) }\end{array}$ & $\begin{array}{c}\text { LSCA e DNUs } \\
\text { manutenção da LSCA para } \\
\text { sem fins lucrativos }\end{array}$ \\
\hline $\begin{array}{l}\text { Orientação narrativa das } \\
\text { políticas de comunicação }\end{array}$ & $\begin{array}{l}\text { Defesa de modelo } \\
\text { privado-comercial }\end{array}$ & $\begin{array}{l}\text { Comunicação como } \\
\text { direito humano }\end{array}$ & $\begin{array}{l}\text { Modelo de negócios } \\
\text { baseado na convergência }\end{array}$ \\
\hline $\begin{array}{l}\text { Acesso à licenças pelo } \\
\text { setor sem fins lucrativos }\end{array}$ & Ilegal / Proibido & $\begin{array}{l}\text { Permitido, com reserva } \\
\text { de espectro reconhecida }\end{array}$ & $\begin{array}{l}\text { Permitido, com reserva } \\
\text { de espectro reconhecida }\end{array}$ \\
\hline Licenças outorgadas & Nenhuma & 161 & $\begin{array}{l}24 \text { (9 são de concursos } \\
\text { da etapa anterior) }\end{array}$ \\
\hline Financiamento & Nenhum & $\begin{array}{c}\text { Desde 2013, fundos } \\
\text { FOMECA (previsto na } \\
\text { LSCA) }\end{array}$ & $\begin{array}{c}\text { Paralisado até novembro } \\
\text { de 2016, depois retomado } \\
\text { (com atrasos) }\end{array}$ \\
\hline
\end{tabular}


Como se percebe no quadro, há legados nas condições normativas e financeiras do processo marcado pela LSCA. Essas condições acompanham a organização de um conjunto de agentes populares na comunicação alternativa no território, que cresceram nesse período (SEGURA et al., 2018) e seguem, agora, produzindo comunicação ascendente e resistindo à nova lógica das políticas de comunicação.

Na mesma perspectiva desse reposicionamento do papel do Estado na retomada neoliberal, também houve mudanças na comunicação pública - as políticas de redução de investimentos e de austeridade parecem guiar a reorganização dos meios do Estado - agora agrupados no Sistema Federal de Meios e Conteúdos Públicos, sob a justificativa da eficiência e da racionalidade (MONJE; RIVERO; ZANOTTI, 2017, p. 84). Essas transformações acompanharam a perda do caráter educativo dos canais que anteriormente estavam no Ministério de Educação - principalmente Encuentro e Pakapaka (BECERRA, 2016). As mudanças de gestão dos canais acompanham, também, recuos em relação aos princípios do canal anteriormente apresentados - como a regionalização da produção, a infância na perspectiva de direitos, a disputa da audiência com canais infantis privados e as ações territoriais (AGRELO, 2016).

Na Televisão Pública Argentina (Canal 7) também houve mudanças, conforme Monje, Zanotti e Rivero (2017, p. 163-167): a remoção dos titulares da direção do canal, por decreto, desrespeitando seus mandatos que perpassavam as gestões presidenciais; uma reorientação da programação e do financiamento, com a ampliação da busca por anunciantes privados; mudanças na grade, com redução das ficções estreadas e dos programas jornalísticos, ampliação da cobertura de eventos populares e o fim da transmissão das principais partidas de futebol. Nesse período, o canal avançou nas estratégias de uso de plataformas digitais e internet (LABATE, 2018). Por outro lado, em 2016, a audiência do canal tinha caído 40\% em comparação ao período de 2011 a 2015 (MONJE; ZANOTTI; RIVERO, 2017, p. 168). 
Outra dimensão da redução da pluralidade desse período esteve relacionada a uma mudança que não trata especificamente de aspectos da LSCA, mas da publicidade estatal. Vários grupos de mídia privados mais próximos ao governo anterior recebiam aportes de publicidade estatal e dependiam desses recursos para financiar suas atividades. Se o uso arbitrário desses recursos era bastante criticado anteriormente, a lógica segue vigente e o novo governo suspendeu ou reduziu drasticamente a publicidade a esses meios. Como afirmam Becerra e Mastrini (2018), os meios com boa sintonia com o governo anterior - como Grupo Veintitrés - se tornaram as principais vítimas da nova política relacionada à publicidade estatal. Houve, segundo Busso (2017), uma espécie de boicote da publicidade para meios comunitários e para meios comerciais opositores ao governo. Ao analisar os dados da publicidade de 2016, Espada e Marino (2017) concluem que se intensificou a concentração da publicidade em poucos grupos. O Grupo Clarín foi o mais prestigiado no período (BECERRA; MASTRINI, 2017d). Com o debate pendente sobre uma regulação para a distribuição desses recursos - que, se desconcentrados e descentralizados geograficamente podem contribuir para promover condições de maior pluralidade e diversidade na mídia (BECERRA; MASTRINI, 2017C) - é fato que os meios afins à oposição tiveram seus problemas de financiamento intensificados.

A redução da publicidade oficial não é o único elemento dessa crise dos meios, pois há dinâmicas da economia do país, do mercado de mídia e das estratégias empresariais que a acompanham. Ela se expressa, além do fechamento de veículos de mídia, pela degradação dos postos de trabalho e das condições trabalhistas no setor. O refluxo dos investimentos do Estado na área e o papel ainda mais dominante dos grupos concentrados em seus mercados participam dessa equação - esses grupos estão entre os que fecharam postos de trabalho desde 2015. Como conta Marino (2017c, tradução nossa),

Foi anunciada a falência da histórica Rádio Rivadavia. Os jornais donos da agência de notícias DyN confirmaram seu fechamento. A um par de dias de 
protesto nos meios do Grupo Indalo (Rádio 10, Pop, Mega, $C_{5} \mathrm{~N}$, todos competitivos em audiência) se seguiu uma greve da União Argentina de Televisão em 16 de novembro. Esses fatos estão inseridos em um conjunto muito mais amplo que começou com o esvaziamento da mídia do Grupo Szpolski [Veintitrés], os problemas nas estações da Electroingeniería, os fechamentos da gráfica AGR (Grupo Clarín) e das revistas da Editora Atlántida; os protestos dos trabalhadores de Perfil e Página/12 (que agora denuncia a discriminação na publicidade oficial) [...] e até mesmo pelos processos de demissões voluntárias no Clarín e no La Nación. A análise de grupos como o FOPEA [Foro de Periodismo Argentino] ou sindicatos como o SIPREBA [Sindicato de Prensa de Buenos Aires] avalia entre 2.000 e 3.000 empregos perdidos nos últimos dois anos.

Ainda que não seja objetivo deste trabalho investigar com profundidade todas as razões dessa crise do mercado de trabalho de comunicação iniciada ao fim de 2015, cabe lembrar que ela aprofunda as graves consequências da concentração de propriedade para a pluralidade e diversidade de ideias em circulação no território argentino.

As transformações na LSCA e na lógica das políticas de comunicação na retomada neoliberal prejudicaram os meios alternativos, comunitários e populares, dos espaços silenciosos - obscurecendo seu lugar no mapa da comunicação (VINELLI, 2017b, p. 16) - e aprofundaram a violência da informação, abrindo, conforme Loreti, Charras e Lozano (2017, p. 63, tradução nossa),

um novo ciclo para a regulação da comunicação na Argentina. O panorama em relação a potenciais violações de direitos não é alentador. Se as medidas adotadas se sustentarem ou se aprofundarem, o espelho retrovisor nos conduzirá aos momentos de maior concentração e estrangeirização dos meios audiovisuais no país e isso seria, sem dúvida, claramente regressivo.

É possível identificar nessas transformações estabelecidas nas políticas de comunicação no marco da retomada neoliberal o que Santos (1998, 2000) identifica como mudança da política dos Estados para a política das empresas. Para ele, “a política agora é feita no mercado. Só que esse mercado global não existe como ator, mas como uma ideologia, um símbolo. Os atores são 
as empresas globais, que não têm preocupações éticas, nem finalísticas" (SANTOS, 2000, p. 67). Há, assim, esforços de racionalização da organização da comunicação no território a partir da lógica das empresas, promovendo usos corporativos do território na comunicação.

Essa retomada da agenda neoliberal a partir do paradigma administrativo e do imperativo da convergência tecnológica dialoga com o que Ribeiro e Silva (2004, p. 351) denominam impulsos da globalização: vetores que condensam informação e inovação, em seus elos com a nova gestão, a "emergência de uma forma de agir de natureza sistêmica e corporativa, que se apropria de condições herdadas e de níveis de controle da mudança permitidos pelo meio técnico-científico-informacional". Segundo as autoras, para as forças dominantes, nem todas as condições herdadas da modernidade recente na formação socioespacial são passíveis de apropriação. Por isso,

para o agir hegemônico - mais preciso, exato e minucioso - a exploração de oportunidades implica na sua simultânea construção, através da quebra de complementaridades materiais e sociais indesejáveis, do alívio estudado de sobrecargas históricas, da redução de exigências, inclusive jurídicas (RIBEIRO; SILVA, 2004, p. 360).

O novo governo, aliado com as corporações midiáticas, pode ser interpretado como impulsor de transformações a serviço desses agentes, buscando a redução das exigências para reordenar o sistema de mídia no território argentino. Esses impulsos representariam um descolamento da ação hegemônica das condições herdadas. Mas, partindo da hegemonia em seu sentido "provisório e parcial, já que orientador da ação de apenas alguns, destilado por características do discurso dominante da globalização", cabe considerar que a "parcialidade deste agir, que se alimenta da velocidade permitida pelas redes técnicas e pelo capital financeiro, não esgota o real" (RIBEIRO; SILVA, 2004, p. 347; 357).

O território usado e praticado contém os sucessivos depósitos de 
tempo, de práticas e de normas. Díaz (2016, p. 15) questiona:

se a democratização da comunicação não se concretizou, se a LSCA não foi aplicada no alcance de todo seu texto, se não se desmonopolizou o mercado de mídia, qual era a necessidade prática de anular os artigos anticoncentração e eliminar os controles do Estado? Nenhuma - e, se houvesse, não era urgente. Mas essas medidas tendiam a criar novos atores no setor, a limitar o crescimento de outros que tendem a concentrar, a privilegiar o caráter social do direito à liberdade de expressão, em suma: a instalar outro paradigma de comunicação.

Paralelamente à racionalidade hegemônica, contrarracionalidades (SANTOS, 2006, p. 309) são instaladas, a partir das minorias, dos pobres, dos agentes não-beneficiados e fundadas nos espaços opacos ou silenciados. Essas contrarracionalidades, potencializadas pelas condições que acompanharam o evento geográfico da LSCA, se instalam a partir desse outro paradigma de comunicação. 
conclusões 


\section{Conclusões}

A construção coletiva de um destino supõe uma responsabilidade à altura da história.

Frantz Fanon, Os Condenados da Terra (1961).

Aunque no podemos adivinar el tiempo que será, sí que tenemos, al menos, el derecho de imaginar el que queremos que sea. En 1948 y en 1976, las Naciones Unidas proclamaron extensas listas de derechos humanos; pero la inmensa mayoría de la humanidad no tiene más que el derecho de ver, oír y callar. ¿Qué tal si empezamos a ejercer el jamás proclamado derecho de soñar?

Eduardo Galeano, El derecho al delirio.

O paradigma do direito à comunicação fundamentou as disputas, de baixo para cima, por um novo marco regulatório democrático da comunicação na Argentina, a partir das demandas dos movimentos sociais organizados (HERNÁNDEZ PRIETO; PÉREZ ALAEJOS, 2017). A pauta ganhou força com a conjuntura que possibilitou o apoio do então governo nacional, da presidenta Cristina Fernández de Kirchner, à aprovação e sanção da Lei de Serviços de Comunicação Audiovisual (LSCA) de 2009, baseada nos 21 pontos da Coalizão por uma Radiodifusão Democrática. No território, foram associadas estratégias da disputa pela difusão de uma outra psicosfera - buscando consolidar no imaginário o apoio à reorganização do sistema de comunicação pretendida, antes e depois da aprovação do novo marco normativo - a ações para reorganizar a tecnosfera de suporte ao funcionamento da comunicação audiovisual, com as disputas pela democratização do espectro radioelétrico, a capilarização da infraestrutura de televisão aberta e ações no contexto de convergência, voltadas ao chamado audiovisual ampliado (MARINO, 2016a).

O evento geográfico marcado pela LSCA acompanhou um novo conjunto de possibilidades e condições normativas no território argentino, a partir de um paradigma que apontava para a ampliação da pluralidade e da diversidade de vozes e maior promoção da comunicação ascendente. Apoiadas nessas novas condições criadas, foram disputadas e realizadas diversas ações, 
incluindo a implementação de políticas, no âmbito do Estado, para a diminuição das desigualdades nas condições de comunicar dos espaços silenciados. Com base na investigação realizada, é possível destacar especialmente as ações, participativas, voltadas à regionalização da produção audiovisual (Polos Audiovisuais) e as conquistas da comunicação comunitária, alternativa e popular - como o reconhecimento e legalização de TVs e rádios, o acesso ao espectro e as políticas de financiamento e fomento.

Foi notório, ainda, que as políticas de comunicação no marco da LSCA evidenciaram um forte protagonismo do Estado, envolvendo: o financiamento tanto da produção de conteúdos para a televisão digital e a partir dos Polos Audiovisuais quanto da comunicação comunitária, alternativa e popular; a distribuição de objetos técnicos adequados à produção e à circulação do audiovisual; investimentos significativos na expansão das redes infraestruturais para a televisão aberta, política satelital e investimentos na base técnica da internet; a criação e priorização de diversos meios de comunicação públicos e estatais; e a estatização das transmissões futebolísticas.

Em dezembro de 2015, a mudança de governo com a eleição de Mauricio Macri trouxe um realinhamento das políticas públicas de comunicação com o interesse dos grandes conglomerados midiáticos e a redução do diálogo com os movimentos sociais da luta da comunicação democrática, acompanhando um novo evento geográfico na América Latina marcado pelo fortalecimento do neoliberalismo. Esse novo sentido das políticas resultou na desconfiguração de aspectos centrais da LSCA, sobretudo aqueles que pretendiam limitar a concentração midiática. Também implicou mudanças profundas da atuação do Estado, com redução e desfinanciamento de políticas públicas que pretendiam reduzir desigualdades historicamente constituídas na formação socioespacial argentina nas condições de comunicar dos diferentes lugares. Conforme Santos (1998), a transferência da política para a esfera do mercado, comandada por grandes empresas globais, representa a 
impossibilidade de uma visão de conjunto, que considere a totalidade do território e seus agentes.

Santos e Silveira (2001, p. 302) lembram que a prática do neoliberalismo acompanha mudanças nos usos do território, tornando-os mais seletivos espacialmente. Segundo os autores, a distribuição geográfica dos provedores de serviços e bens tendem a concentrar-se, já que as empresas vão buscar os lugares que já acumulam os atributos mais vantajosos no território - as maiores densidades técnicas e informacionais. A reorientação da política de comunicação na Argentina, baseada na narrativa da convergência tecnológica, aponta para uma maior concentração midiática e para a possibilidade dos grandes grupos estarem presentes e atuantes em mais setores (BECERRA; MASTRINI, 2018). Esse projeto aponta, assim, para uma ampliação da densidade informacional, com a redução das condições para a densidade comunicacional dos lugares, sobretudo nos espaços opacos da globalização.

A reorientação das políticas de comunicação e o desmonte do marco normativo e institucional da LSCA trouxeram à tona avaliações sobre seus limites. Para Moraes (2017, p. 42), é preciso reconhecer que os avanços, tanto no âmbito do Estado quanto da sociedade civil, ainda não foram suficientes para reduzir o enorme peso histórico dos grupos privados na área das comunicações. Como afirmam Longo et al. (2017, p. 49), a LSCA representou uma tentativa de impor limites à concentração de propriedade privada da mídia, a multiplicação de meios públicos e estatais, além da legalização e fomento aos meios sem fins lucrativos. Por outro lado, as autoras também consideram que, nesse processo, não se chegou a reverter as condições de profunda desigualdade do sistema midiático do país.

Tentar mensurar resultados de um processo de curta duração como esse é difícil, ainda que haja algumas iniciativas nesse sentido. No caso aqui estudado, poderíamos mencionar, de um lado, um relatório sobre diversidade cultural da UNESCO (2015, p. 53), que aponta um crescimento de $28 \%$ de 
conteúdo local em canais de mídia regionais entre 2009 e 2015 na Argentina, resultado atribuído à LSCA; de outro lado, o índice de Relação de Concentração dos quatro principais operadores do mercado - $\mathrm{CR}_{4}{ }^{101}$ aponta ${ }^{102}$ para uma manutenção da concentração midiática no país nesse curto intervalo (BECERRA; MASTRINI, 2017a, p. 93). Cabe lembrar que houve uma judicialização da LSCA para evitar o processo de adequação de grupos grandes aos limites à concentração.

Essas perspectivas, no entanto, não esgotam a complexidade das dinâmicas de organização da comunicação no território usado. Santos (2006, p 337) lembra "que o mundo é apenas um conjunto de possibilidades, cuja efetivação depende das oportunidades oferecidas pelos lugares" e que o exercício da ação passa a depender "da existência, neste ou naquele lugar, das condições locais que garantam eficácia aos respectivos processos", mediadas pela formação socioespacial. Desse modo, o debate sobre a efetividade das políticas públicas de comunicação deve considerar as heranças legadas no território praticado - suas diferentes densidades e rarefações, as condições de organização dos agentes e as materialidades que condicionam os usos do território.

Muitos dos trabalhos citados ao longo desta tese partem da perspectiva da análise das ações dos governos e dão ênfase às coerências, contradições e falhas na implementação de aspectos da lei como principais entraves à plena aplicação da LSCA. Essa aplicação ou implementação da política não é aespacial. Assim, acreditamos que deve ser dada maior ênfase às desigualdades herdadas no território - que impõem inércias dinâmicas às transformações - e à correlação de forças desigual entre os agentes. Como aborda Massey (2007), se trata de considerar as geometrias do poder, levando em

101 Conforme Domingues da Silva (2016, p. 3), a Relação de Concentração (CR) mede a parcela de participação de um número determinado de firmas no contexto geral da indústria examinada. No caso da mídia, costuma ser usado o indicador $\mathrm{CR} 4$, que abarca a somatória do percentual de mercado dos quatro principais operadores.

102 Comparando dados de 2008 com 2014, na rádio o CR4 caiu de 64\% para 58\%, na televisão aberta de $97 \%$ para $92 \%$, mas na televisão paga cresceu de $67 \%$ para $84 \%$, explicado pelo crescimento da operadora DirecTV (BECERRA; MASTRINI, 2017a, p. 95). 
conta os vínculos repletos de relações de poder desiguais no espaço.

\section{Um olhar territorial para as políticas de comunicação}

Compreender a complexidade das desigualdades territoriais que constituem, historicamente, cada formação socioespacial e sua diversidade regional é fundamental para pensar um planejamento territorial democrático e, em particular, para pensar políticas voltadas à democratização da comunicação a partir de uma perspectiva geográfica. Ampliar a capacidade de "fala" e de "escuta" dos lugares passa por transformar as condições materiais e imateriais, técnicas e normativas dos lugares.

A efetivação do direito à comunicação deve considerar essa dimensão territorial - "é impossível imaginar uma cidadania concreta que prescinda do componente territorial" (SANTOS, 2007, p. 144-150). Trata-se, assim, de partir das realidades dos lugares para planejar ações, promover direitos e reduzir as desigualdades - buscar uma justiça espacial ou socioespacial baseada não só na distribuição, mas na coprodução de bens e serviços (LÉVY, 2013, 2014).

Para tanto, há um conjunto de diferenciações no território sobrepostas que precisam ser consideradas, entre as quais se destaca: áreas da fluidez e da viscosidade; zonas de densidade e rarefação; e espaços luminosos e opacos da globalização (SANTOS; SILVEIRA, 2001, p. 258-277). A análise da fluidez territorial e da viscosidade compreende as condições para a circulação material e imaterial, que envolvem fatores que vão da disposição das materialidades à condição financeira, passando pelas normas, usos e costumes. Usualmente, as condições para a fluidez material e imaterial no território não têm relação direta "com o tamanho e a densidade da população, nem com a antiguidade do povoamento, nem com as urgências das sociedades locais, mas com os nexos econômicos" (SANTOS; SILVEIRA, 2001, p. 261-262). Conforme Santos e Silveira, pode-se, também, distinguir a fluidez virtual (ou potencial) de uma fluidez efetiva do território. A fluidez virtual seria medida pela presença das 
materialidades e objetos técnicos necessários à circulação. No entanto, a fluidez efetiva depende do uso real do território. A agenda da democratização da comunicação deve considerar a necessidade de transformar as condições materiais para ampliar a fluidez potencial dos espaços isolados da circulação (sobretudo das informações). Nessa direção, várias ações foram pautadas no território argentino em decorrência da LCSA, como visto.

No entanto, é crucial lembrar que não bastam essas transformações de ordem material para a mudança dos usos efetivos do território. Nesse sentido, devem ser consideradas as distintas densidades e rarefações no espaço geográfico - técnicas, informacionais e comunicacionais (SANTOS, 2006, p. 257258). A agenda da democratização da comunicação deve estar voltada à promoção de condições para a densidade comunicacional dos espaços silenciados, abrangendo o fomento e as capacidades de organização dos agentes. Por fim, é possível resgatar às noções de espaços luminosos e opacos da globalização e o entendimento, já proposto aqui, de que os espaços opacos são espaços "silenciosos" ou espaços "do silêncio" (ROJAS, 2014). É possível reconhecer processos históricos de silenciamento dos lugares, que devem ser rompidos a partir da criação de condições para a ampliação de sua densidade comunicacional.

Assim, nos parece que a noção de comunicação ascendente é fundamental para a organização de políticas de comunicação e das demandas dos agentes que lutam pela democratização da mídia, na medida em que inspira ou promove uma busca para potencializar a comunicação horizontal a partir dos cotidianos vividos nos lugares. Várias experiências aqui analisadas, no marco da LSCA, apontavam nessa direção, sobretudo ao promover políticas de regionalização das condições de produção e circulação do audiovisual e ao apoiar os agentes contra-hegemônicos de meios comunitários, populares e alternativos.

Conforme Serpa (2011, p. 174), a análise das táticas de apropriação 
socioespacial dos meios de comunicação ajuda a revelar que os lugares são enunciados a partir de representações espaciais que são coerentes com as trajetórias e cotidianos dos agentes. Para o autor, as possibilidades de enunciação dos lugares são condicionadas pelo acesso aos meios de comunicação, colocados como condição para a produção de conteúdos sobre o lugar. Além disso, quanto maior a disponibilidade e o acesso aos meios de comunicação nos lugares, maior a possibilidade de surgimento e consolidação das representações espaciais de iniciativas e grupos não-hegemônicos (SERPA, 2011, p. 175).

É fundamental, conforme Ribeiro (2013b, p. 69-70), considerar esses valores e anseios que povoam e movimentam o imaginário de um lugar em um período - apreendendo a imaginação como fenômeno coletivo, pleno de razão e emoção, marcado pela cotidianidade vivida. Fato é que a própria possibilidade de imaginação dos lugares passa pela condição de criar e fazer circular essas representações - para Massey (2017, p. 37), "podemos examinar como tais imaginações são produzidas, seja através dos nexos de poderosos conglomerados de mídia internacionais ou do imaginário persistente e implantado em conversas locais". Nesse último caso, é fundamental pensar como as condições para a produção de informações ascendentes podem potencializar esses nexos fundados no cotidiano dos lugares, tendo a possibilidade de ampliar suas escalas. Em sentido oposto, a partir do predomínio das informações descendentes, podem ser criadas mistificações dos lugares, como aborda Lencioni (2009, p. 19).

As políticas de comunicação com vistas a democratizar a comunicação passam, portanto, pela promoção da comunicação ascendente. Em especial, devem ser políticas construídas a partir da participação efetiva de todos os agentes, sobretudo os "de baixo", historicamente silenciados. O evento geográfico marcado pela LSCA tem como legado um horizonte de possibilidades de ações nesse sentido. Na mesma direção, é importante lembrar que seu desmonte 
normativo e institucional não implica o fim das contrarracionalidades, das experiências de comunicação ascendente e contra-hegemônica que povoam o território argentino. Muitas dessas potencializaram e foram potencializadas pelas condições desse evento, e tantas resistem atualmente apesar das dificuldades criadas.

\section{Busca de consensos ativos e outros futuros possíveis}

É fundamental reconhecer o evento em torno da LSCA como uma construção a partir de uma agenda das ruas (SANTANDER, 2014), de baixo pra cima - para Bulla (2011), desde a concepção até as instâncias de participação que propõe, teria sido uma das políticas públicas com maior intervenção popular desde a redemocratização do país. Reconhecer a força do tecido social no território é fundamental para escapar da tendência a substituir ou reduzir, na análise, as lutas dos movimentos sociais pelas políticas públicas resultantes (RIBEIRO, 2013b, p. 194-195).

Apresentaram-se, nesse processo, possibilidades de participação popular desde a formulação à condução das políticas de comunicação. O caso do programa Polos Audiovisuais Tecnológicos é paradigmático nessa perspectiva: a proposta de gestão associada (POGGIESE, 2011) entre a trama de agentes locais e o Estado, com metodologias participativas, estimulava oportunidades de trocas, pactos e interlocuções a partir dos cotidianos e demandas dos lugares. A partir da experiência do PAT, Poggiese e Piwowarski (2016, n.p, tradução própria) propõem "territorializar a batalha cultural", com esse modelo de gestão associada como possibilidade para outras iniciativas de comunicação baseada nos lugares:

Por que não se associar de alguma forma especial, para uma faixa de comunicação, sem perder sua identidade ou autonomia, mas produzindo uma mensagem de comunicação conjunta, uma agência de notícias local, um programa de rádio e/ ou TV com projeto e recursos mistos, que possa ser lido e entendido como um produto de um coletivo [...]? Nos 21 pontos recentes da Coalizão para uma Comunicação Democrática (CCD), estão previstas formas mistas de associação pública e privada. [...] A gestão associada e conjunta é 
uma possibilidade legal [...] E, de fato, a prática de tal associação foi experimentada por vários anos, nos esforços de construir uma indústria de TV local.

Para os autores, "modelos territorializados de comunicação democrática" devem estar na agenda da democratização midiática. A ideia é que a inovação também esteja nos meios, não só nas mensagens : significa "apostar que a equação democratizadora da comunicação se joga na natureza do ator que a produz". No caso dessa associação, seria "gerada uma modificação não só na mensagem, como também no tecido social que a sustenta e a produz" (POGGIESE; PIWOWARSKI, 2016, n.p, tradução própria).

Esse processo nos remete ao que García Linera (2009, p. 500-501) chama de relação-Estado, uma estrutura de relações políticas territorializadas, um fluxo de interrelações e materializações passadas dessas interrelações que se referem à dominação e legitimação política no âmbito do Estado. Para o autor, uma das formas de pensar essa relação é em termos do Estado como correlação política de forças sociais. Nesse sentido, os processos participativos, construídos de baixo para cima, potencializam a capacidade dos movimentos sociais e da diversidade de agentes dos lugares de influírem nas políticas e decisões dos recursos do Estado. É esse o sentido que as políticas de comunicação devem tomar, buscando caminhos para a construção de consensos ativos (ARROYO, 2015). Também importante é reconhecer a importância de governos populares e progressistas a essas conjunturas, por promoverem maior abertura a essas demandas, disputas e possibilidades de avanço das pautas dos movimentos.

O desmonte normativo e institucional da LSCA não deve ser visto como a aniquilação do processo ou de suas conquistas. Ao interpretá-lo a partir da sobreposição de eventos geográficos, é possível, conforme Santos (1999, p. 16), compreender o tempo da existência de possibilidades concretas, "tanto da história feita, quanto da história por fazer". Segundo o autor, esse entendimento do mundo como possibilidade de um futuro realizável é a negação da ideia dos 
impossíveis. O autor também lembra que o mundo "definido pela literatura do pensamento único é, somente, o conjunto de formas particulares de realização de apenas um certo número de possibilidades" (SANTOS, 2000, p. 160). Por isso, situações como a reversão dos avanços na democratização da comunicação na Argentina podem parecer definitivos, mas não são eternos. Assim, para M. Santos, "é lícito dizer que o futuro são muitos, e resultarão de arranjos diferentes, segundo nosso grau de consciência, entre o reino das possibilidades e o reino da vontade" (SANTOS, 2000, p. 161). Além das responsabilidades à altura da história, como clama Frantz Fanon na epígrafe, é fundamental reconhecer as possibilidades concretas do período histórico e da formação socioespacial para as ações transformadoras,. Essas possibilidades são produzidas ao longo do tempo e favorecem novos processos, conforme sua realização nos lugares, que acumulam densidades técnicas, informacionais e comunicacionais, condições de organização, materialidades e normas. A situação geográfica de Misiones, aqui estudada, parece reveladora dessa potência.

Promover a comunicação ascendente, a pluralidade e diversidade de vozes é fundamental para ampliar as possibilidades de gestar projetos alternativos aos dominantes. Para Santos (2000, p. 174), pouco se fala da possibilidade de assegurar uma mutação filosófica da humanidade, "capaz de atribuir um novo sentido à existência de cada pessoa e, também, do planeta". Para isso, urge democratizar a comunicação a partir de um olhar territorial, levando novas condições aos espaços silenciosos que permitam a ampliação das vozes, agentes e lugares representados. Disso depende a possibilidade de produzir outros sentidos à nossa existência e romper com o pensamento único. Concordamos com Milton Santos que esse mundo novo anunciado não será uma construção de cima para baixo, mas uma edificação cuja trajetória vai ser dar de baixo para cima (SANTOS, 2000, p. 170).

Eduardo Galeano, mencionado no início dessa reflexão, reclama nosso direito de sonhar. Esse direito passa pelo reconhecimento das possibilidades, 
pelas experiências vivenciadas. Conforme Ana Clara Torres Ribeiro (2010, p. 15), "o pensamento do futuro não é exclusivamente uma projeção a partir do presente, mas é algo que volta ao futuro através dos passados negados". Os recuos a partir do desmonte da LSCA podem apontar para expectativas interditadas, mas os avanços da curta experiência de efetivação de ações para a democratização da comunicação no território argentino permanecem como possibilidade de futuro e compõem nosso repertório de ações para produzir outra globalização. 


\section{Referências bibliográficas}

AAG. Media and Communication Geography Specialty Group. Disponível em: $<$ http://community.aag.org/communities/community-home?CommunityKey=a4e40171-8c58-4343-8fc4432b13d7b262>. Acesso em: 7 jul. 2018.

ADAMS, Paul. A taxonomy for communication geography. Progress in Human Geography v. 35, n. 1, p. 3757 , fev. 2011.

ADAMS, Paul. Geographies of media and communication I: Metaphysics of encounter. Progress in Human Geography p. 0309132516628254,24 jan. 2016.

ADAMS, Paul. Geographies of media and communication II: Arcs of communication. Progress in Human Geography p. 0309132517702992,12 abr. 2017.

ADAMS, Paul. Theatrical territoriality: a geographical enquiry into protest occupations and mass communications. PhD dissertation - University of Wisconsin-Madison, 1993.

AGNEW, John A.; CORBRIDGE, Stuart. Mastering Space: Hegemony, Territory and International Political Economy. [S.1.]: Routledge, 1995. 275 p. .978-0-415-09434-4.

AGRELO, Facundo. Entrevista de Facundo Agrelo ao autor, em Buenos Aires, sobre o Pakapaka e a Ley de Servicios de Comunicación Audiovisual . [S.l: s.n.]. , 3 maio 2015

AGRELO, Facundo. Entrevista de Facundo Agrelo ao autor, em Buenos Aires, sobre o Pakapaka e as mudanças nas políticas de comunicação no governo Macri . [S.l: s.n.]. , 15 dez. 2016

AGUIAR LOPES, Sonia. Geografias da comunicação contemporânea: um mapa teórico e empírico do campo. Contemporânea (Título não-corrente) v. 11, n. 1 , 2013. Disponível em: <http://www.epublicacoes.uerj.br/index.php/contemporanea/article/view/6960>. Acesso em: 22 nov. 2016.

AGUIAR LOPES, Sonia. Territórios do Jornalismo: geografias da mídia local e regional no Brasil. Petrópolis (RJ): Vozes, 2016. .

AGUIAR, Pedro. Agências de Notícias do Sul Global: jornalismo, Estado e circulação da informação nas periferias do sistema-mundo. Tese (Doutorado em Comunicação) - UERJ, Rio de Janeiro, 2018. 667 p.

AGUIAR, Pedro. Sistemas internacionais de informação Sul-Sul: do pool não-alinhado à comunicação em redes. Dissertação (Mestrado) - UERJ, Rio de Janeiro, 2010.

AHARONIAN, Aram. La Corte Suprema argentina declaró constitucional la Ley de Medios. Disponível em: <https://www.alainet.org/es/active/68559>. Acesso em: 16 jan. 2018.

AHARONIAN, Aram. La Internacional del Terror Mediático. Buenos Aires: Punto de Encuentro, 2015.

ALABARCES, Pablo; DUEK, Carolina. Fútbol (argentino) por TV: entre el espectáculo de masas, el monopolio y el estado. Logos 33 Comunicação e Esporte v. 17, n. 2, 2010. Disponível em: <http://www.logos.uer..br/PDFS/33/02_logos33_alabarces_duek_futebolargentino.pdf >. Acesso em: 21 jun. 2016.

ALA-FOSSI, Marko et al. El imperio del aire: Espectro raidoeléctrico y radiodifusión. Barcelona: Editorial UOC, 2017. .

ALBORNOZ, Luis A. Comunicação plural, diversidade cultural. In: DANTAS, Marcos; KISCHINHEVSKY, Marcelo (Orgs.). . Políticas públicas e pluralidade na comunicação e na cultura. Rio de Janeiro: EPapers, 2014. 
ALBORNOZ, Luis A.; CAÑEDO, Azahara. Diversidad y televisión en Argentina: el caso del Programa Polos Audiovisuales Tecnológicos. CIC. Cuadernosde Información y Comunicación n. 21, p. 179-200 , 2016.

ALBORNOZ, Luis A.; HERNÁNDEZ, Pablo. La radiodifusión en Argentina entre 1995 y 1999: concentración, desnacionalización y ausencia de control público. In: MASTRINI, Guillermo (Org.). . Mucho ruido, pocas leyes: economia y políticas de comunicación en la Argentina (1920-2007). Buenos Aires: La Cruija, 2009.

ALIAGA, Jorge. Charla sobre la historia de Arsat, por Jorge Aliaga . [S.l: s.n.]. Disponível em: <https://www.youtube.com/watch?v=Q9VHEDiMpNY>. Acesso em: 13 jul. 2018. , 2017

ÁLVAREZ GANDOLFI, Federico. ¿La asombrosa excursión de Zamba en las escuelas? Cuadernos de H Ideas v. 07, nº 07, dez. 2013. Disponível em: <http://hdl.handle.net/10915/32784>. Acesso em: 20 ago. 2018.

ALVES, Cristiano Nunes. Metrópole e informação: a radiodifusão na região do Recife. Geosul v. 33, n. 66, p. 48-69, 2 mar. 2018.

ALVES, Cristiano Nunes. Quando as ruas abrigam a arte: a cena hip hop no Recife (1980-2014). Confins n. 25 , 2015. Disponível em: <https://journals.openedition.org/confins/10426>. Acesso em: 30 jul. 2018.

AMORIM, Ana Paola. A opinião pública democrática e a defesa pública da liberdade de expressão. In: LIMA, Venício De; GUIMARÂES, Juarez (Orgs.). . Liberdade de expressão: as várias faces de um desafio. São Paulo: Paulus, 2009.

ANDRADE, Manuel Correia. O Brasil e a América Latina. São Paulo: Contexto, 1996. .

ANESINI, Diego. Barómetro Cisco de Banda Ancha Argentina 2005-2010 . [S.1.]: IDC Latin America. Disponível em: <http://www.cicomra.org.ar/cicomra2/img/informes_especiales/fotos/IV\%20Barometro\%2020052010.pdf>. , 2009

ANRED. Foto-informe: medios comunitarios movilizaron al ENACOM por Fomecas impagos .ANRed. [S.l: s.n.]. Disponível em: <http://www.anred.org/?p=58068>. Acesso em: 3 set. 2018. , 27 jul. 2016

ANTAS JR, Ricardo Mendes. Território e regulação: espaço geográfico, fonte material e não-formal do direito. São Paulo: Humanitas, 2005. .85-98292-55-9.

ARANHA, Taís. Comunicação Popular, Comunitária, Horizontal ou Dialógica? Articulações e Diferenças entre os Conceitos Teóricos. In: I CONFERÊNCIA SUL-AMERICANA DE MÍDIA CIDADÃ, 2010, Pato Branco (PR). Anais... Pato Branco (PR): FADEP, 2010.

ARGENTINA. Aportes para el desarrollo de la TDA - Informes de I+D del Programa Polos Audiovisuales Tecnológicos - Consumos y audiencias . [S.l.]: Ministerio de Planificación Federal, Inversión Pública y Servicios. , $2013 a$

ARGENTINA. Aportes para el desarrollo de la TDA - Informes de I+D del Programa Polos Audiovisuales Tecnológicos - Sustentabilidad y nuevos mercados . [S.l.]: Ministerio de Planificación Federal, Inversión Pública y Servicios. , 2013b

ARGENTINA. Atlas cultural de la Argentina 2014. Disponível em: <https://issuu.com/secretariadecultura/docs/atlas-cultural-de-la-argentina>. Acesso em: 21 jul. 2018 a.

ARGENTINA. Decisión Administrativa 221/2009. Disponível em: <http://servicios.infoleg.gob.ar/infolegInternet/anexos/155000-159999/157297/norma.htm>. Acesso em: 21 jun. 2016a.

ARGENTINA. Decreto 236/2015. , 22 dez. 2015 a . Disponível em: <http://servicios.infoleg.gob.ar/infolegInternet/anexos/255000-259999/257248/norma.htm>. Acesso em: 1 set. 2016. 
ARGENTINA. Decreto 267/2015. , 29 dez. 2015 b . Disponível em: <http://servicios.infoleg.gob.ar/infolegInternet/anexos/255000-259999/257461/norma.htm>. Acesso em: 2 maio 2016.

ARGENTINA. Decreto 554/1997 . [S.l: s.n.]. Disponível em: <http://servicios.infoleg.gob.ar/infolegInternet/anexos/40000-44999/44083/norma.htm>. Acesso em: 14 mar. 2018. , 18 jun. 1997

ARGENTINA. Decreto 1148/2009 . [S.l: s.n.]. Disponível em: <http://servicios.infoleg.gob.ar/infolegInternet/anexos/155000-159999/157212/norma.htm>. Acesso em: 14 jan. 2018b. , 31 ago. 2009

ARGENTINA. Decreto 1552/2010 . [S.l: s.n.]. Disponível em: <http://servicios.infoleg.gob.ar/infolegInternet/anexos/170000-174999/174110/norma.htm>. Acesso em: 14 jan. 2018a. , 21 out. 2010

ARGENTINA. El Estado del Estado: Diagnóstico de la Administración Pública en diciembre de 2015. Disponível em: <http://www.sigen.gob.ar/pdfs/el_estado_del_estado.pdf>. Acesso em: 24 ago. 2018.

ARGENTINA. Ley 26.092 - Empresa Argentina de Soluciones Satelitales Sociedad Anónima AR-SAT. , 26 abr. 2006 . Disponível em: <http://servicios.infoleg.gob.ar/infolegInternet/anexos/115000-119999/115886/norma.htm>. Acesso em: 13 jul. 2018.

ARGENTINA. Ley 26.522 - Ley de Servicios de Comunicación Audiovisual. , 10 out. 2009 c . Disponível em: <http://bit.ly/leidemeios>. Acesso em: 12 jun. 2016.

ARGENTINA. Ley 27.078 - Argentina Digital. , 18 dez. 2014 b . Disponível em: <http://servicios.infoleg.gob.ar/infolegInternet/anexos/235000-239999/239771/norma.htm>. Acesso em: 6 jan. 2018.

ARGENTINA. Ley 27.208 - Plan Satelital Geoestacionario Argentino. , 9 nov. 2015 c . Disponível em: $<$ http://servicios.infoleg.gob.ar/infolegInternet/anexos/250000-254999/254823/norma.htm>. Acesso em: 13 jul. 2018.

ARGENTINA. Plan Nacional de Telecomunicaciones Argentina Conectada. Disponível em: <http://scripts.minplan.gob.ar/octopus/archivos.php?file=2802>. Acesso em: 21 jul. 2016b.

ARGENTINA. Polos Audiovisuales Tecnologicos: Plan Piloto de Testeo y Demostración de Capacidades Instaladas . [S.l.]: Ministerio de Planificación Federal, Inversión Pública y Servicios. , 2012

ARGENTINA. Programa Polos Audiovisuales Tecnológicos - Informe .[S.l.]: TDA. , 2015d

ARGENTINA. Regionalización - Nota Metodológica . [S.1.]: Ministerio de Economía y Finanzas Públicas. , 2011

ARROYO, Mónica. A América Latina numa encruzilhada: ocaso do projeto de integração? GeoTextos v. 13, n. 1, 30 jul. 2017. Disponível em: <https://rigs.ufba.br/index.php/geotextos/article/view/23363>. Acesso em: 22 jan. 2018.

ARROYO, Mónica. A vulnerabilidade dos territórios nacionais latino-americanos: o papel das finanças. In: LEMOS, Amalia Inés Geraiges De; SILVEIRA, María Laura; ARROYO, Mónica (Orgs.). . Questões territoriais na América Latina. Buenos Aires: CLACSO, 2006.

ARROYO, Mónica. América Latina na aurora do século XXI: por uma busca de consensos ativos. Ciência Geográfica v. XIX, p. 16-23, 2015.

ARROYO, Mónica. Globalização e espaço geográfico. Experimental n. 6, p. 15-31, 1999.

ARROYO, Mónica. Território, mercado e Estado: uma convergência histórica. GEOgraphia v. 6, n. 12 , 2004.

ARSAT. Portal de Datos Abiertos. Disponível em: <http://datos.arsat.com.ar/home>. Acesso em: 12 jun. 2018.

278 | Referências bibliográficas 
BAGDIKIAN, Ben. The New Media Monopoly. Boston (EUA): Beacon Press, 2004. Disponível em: <https://www.goodreads.com/work/best_book/146358-the-new-media-monopoly>. Acesso em: $30 \mathrm{dez}$. 2017. .

BAKIS, Henry. Communications et territoires. 1. ed. Paris: La Documentation Française, 1990. 1 v. .978-2-11002401-5.

BALADRON, Mariela. El Plan Nacional de Telecomunicaciones Argentina Conectada (2010-2015) en el marco de las políticas públicas de universalización del acceso a internet. Tesis de maestría (Industrias Culturales) - Universidad Nacional de Quilmes, Bernal, 2018. 182 p.

BALADRON, Mariela. La radiodifusión argentina después de la crisis de 2001: la política de comunicación del gobierno de transición de Eduardo Duhalde. In: MASTRINI, Guillermo (Org.). . Mucho ruido, pocas leyes: economia y políticas de comunicación en la Argentina (1920-2007). Buenos Aires: La Cruija, 2009.

BALADRON, Mariela; RIVERO, Ezequiel; ROCA, Alejandra. Políticas digitales de democratización en la Argentina 2010-2015. Actas de Periodismo y Comunicación v. 2, n. 1 , 29 maio 2017. Disponível em: <https://www.perio.unlp.edu.ar/ojs/index.php/actas/article/view/3707>. Acesso em: 9 jul. 2018.

BALDESSAR, Maria José; MOREIRA, Sonia Virginia; PASTI, André. Geografia e comunicação: diálogos mais que possíveis. In: MORAIS, Osvando J. De (Org.). . Ciências da comunicação em processo: paradigmas e mudanças nas pesquisas em comunicação no século XXI: conhecimento, leituras e práticas contemporâneas. São Paulo: Intercom, 2014. p. 739.

BARANCHUK, Mariana. Canales 11 y 13: la primera privatización de la década menemista. In: MASTRINI, Guillermo (Org.). . Mucho ruido, pocas leyes: economia y políticas de comunicación en la Argentina (1920-2007). Buenos Aires: La Cruija, 2009.

BARBOSA, Bia; EKMAN, Pedro. Nas comunicações, tudo como antes na história deste país. In: MARINGONI, Gilberto; MEDEIROS, Juliano (Orgs.). . Cinco mil dias: o Brasil na era do lulismo. São Paulo: Boitempo, 2017.

BARENDT, Eric. Freedom of Speech. Oxford: Oxford University Press, 2005.

BECERRA, Martín. De la concentración a la convergencia: políticas de medios en Argentina y América Latina. Buenos Aires: Paidós, 2015. .

BECERRA, Martín. La sociedad de la información. p. 10 , 2003.

BECERRA, Martín. Las noticias van al mercado: etapas de intermediación de lo público en la historia de los medios de la Argentina. In: LUGONES, Gustavo; FLORES, Jorge (Orgs.). . Intérpretes e interpretaciones de la Argentina en el bicentenario. Bernal: Universidad Nacional de Quilmes, 2010.

BECERRA, Martín. Las políticas de infocomunicación ante la Cumbre Mundial de la Sociedad de la Información (CMSI). Quaderns del CAC n. 21, p. 125-139 , 2005.

BECERRA, Martín. Los medios públicos más allá de la consigna. ámbito, 31 maio 2013. Disponível em: <http://www.ambito.com/690893-los-medios-publicos-mas-alla-de-la-consigna >. Acesso em: 20 ago. 2018.

BECERRA, Martín. Los parches que zurcen la gran fusión. Letra P , 24 abr. 2018. Disponível em: <http://www.letrap.com.ar/nota/2018-4-24-16-55-0-los-parches-que-zurcen-la-gran-fusion>. Acesso em: 3 set. 2018.

BECERRA, Martín. Macri decreta cambios en Encuentro y Paka-Paka .QUIPU. [S.l: s.n.]. Disponível em: <https://martinbecerra.wordpress.com/2016/12/05/macri-decreta-cambios-en-encuentro-y-paka-paka/>. Acesso em: 3 set. 2018. , 5 dez. 2016 
BECERRA, Martín. Macri y lo que sigue. In: MASTRINI, Guillermo; BECERRA, Martín (Orgs.). . Medios en guerra: Balance, crítica y desguace de las políticas de comunicación 2003-2016. Buenos Aires: Biblos, 2017.

BECERRA, Martín. Medios de comunicación: América Latina a contramano. Nueva Sociedad n. 249 , fev. 2014.

BECERRA, Martín; MARINO, Santiago; MASTRINI, Guillermo. Mapping Digital Media: Argentina . [S.l.]: Open Society Foundations. Disponível em: <https://www.opensocietyfoundations.org/sites/default/files/mapping-digital-media-argentina-20121107.pdf>. , 29 fev. 2012

BECERRA, Martín; MASTRINI, Guillermo. La concentración infocomunicacional en América Latina 20002015: nuevos medios y tecnologías, menos actores. Bernal: Universidad Nacional de Quilmes; Observacom, 2017a. Disponível em: <http://www.unq.edu.ar/advf/documentos/5a200eoe93ac2.pdf>. Acesso em: 4 jan. 2018.

BECERRA, Martín; MASTRINI, Guillermo. La ley de servicios de comunicación audiovisual: proceso de construcción y contenidos básicos. In: MASTRINI, Guillermo; BECERRA, Martín (Orgs.). . Medios en guerra: Balance, crítica y desguace de las políticas de comunicación 2003-2016. Buenos Aires: Biblos, 2017b.

BECERRA, Martín; MASTRINI, Guillermo. Las políticas de comunicación del kirchnerismo y la agenda pendiente. In: MASTRINI, Guillermo; BECERRA, Martín (Orgs.). . Medios en guerra: Balance, crítica y desguace de las políticas de comunicación 2003-2016. Buenos Aires: Biblos, 2017C.

BECERRA, Martín; MASTRINI, Guillermo. Los dueños de la palavra: acceso, estructura y concentración de los medios en la América Latina del Siglo XXI. Buenos Aires: Prometeo Libros, 2009. .

BECERRA, Martín; MASTRINI, Guillermo. Macri achicó el gasto en publicidad pero aseguró su alianza con Clarín: le dio el 21\%. Letra P 17 jan. 2017d Disponível em: <http://www.letrap.com.ar/nota/2017-1-17--macriachico-el-gasto-en-publicidad-pero-lo-concentro-le-dio-el-21-a-clarin>. Acesso em: 2 set. 2018.

BECERRA, Martín; MASTRINI, Guillermo. Más dueños que nunca. Revista Anfibia (Universidad Nacional de San Martín) , jun. 2018. Disponível em: < https://www.revistaanfibia.com/ensayo/mas-duenosnunca/>. Acesso em: 3 set. 2018.

BECERRA, Martín; WAISBORD, Silvio. Principios y "buenas prácticas" para los medios públicos en América Latina . [S.l.]: Unesco. , 2015

BELISÁRIO, Adriano; LARA, Paulo José O. M. Comunicação, vigilância e infraestrutura: tecnopolíticas do espectro eletromagnético | Communication, surveillance and infrastructure: techno-politics of the electromagnetic spectrum. Liinc em Revista v. 12, n. 2 , 30 nov. 2016. Disponível em: <http://revista.ibict.br/liinc/article/view/3722>. Acesso em: 17 jun. 2018.

BENEDETTI, Alejandro. Los espacios fronterizos binacionales del sur sudamericano en perspectiva comparada. Revista GeoPantanal v. 8, n. 15, p. 37-62, 17 nov. 2014.

BENEDETTI, Alejandro; SALIZZI, Esteban. 150 años de Geografía Regional en Argentina: cambios y continuidades en las propuestas de regionalización del territorio nacional (1839 a 1988). Folia Histórica del Nordeste n. 25, p. 11-34, 2016.

BENKLER, Yochai. Overcoming Agoraphobia: Building the Commons of the Digitally Networked Environment. p. $113,1998$.

BERGERO, Fabian. Televisión Digital: El cambio de paradigma y los desafíos para el Estado argentino . [S.l: s.n.]. Disponível em: <https://www.academia.edu/4225026/Televisi\%C3\%B3n_Digital_El_cambio_de_paradigma_Y_los_desaf\%C3\%ADos_para_el_Estado_argentino?auto=download $>$. Acesso em: 18 jul. 2016. , 2012 
BERNARDO, Muriel; GIBEAUD, Eliana; ELEM, Vivian. Entrevista sobre o Programa Polos Audiovisuales Tecnologicos. . [S.l: s.n.]. , 27 jan. 2016

BERTOLLO, Mait. O Smartphone a Capilarização pelo Território das Redes para Informação e Comunicação. In: XXXV I I I CONGRESSO BRASILEIRO DE CIÊNCIAS DA COMUNICAÇÃO, 2015, Rio de Janeiro. Anais... Rio de Janeiro: Intercom, 2015.

BEZERRA, André Augusto Salvador. Políticas públicas de comunicação social e liberdade de expressão: os casos da Argentina, Bolívia, Equador e Venezuela. Cadernos PROLAM/USP v. 1, n. 11 , 2012.

BIZBERGE, Ana. Hacia un escenario de ¿convergencia? Los cambios en la política regulatoria de Argentina y Brasil. In: BALDESSAR, Maria José; MONJE, Daniela Inés (Orgs.). . Diálogos latino-americanos: comunicação e democracia em tempos de convergência. São Paulo: Intercom, 2018.

BIZBERGE, Ana et al. Políticas de TDT: del predomínio del mercado al desafío por un sistema democrático de televisión. In: MASTRINI, Guillermo; BIZBERGE, Ana; CHARRAS, Diego De (Orgs.). . Las políticas de comunicación en el siglo XXI: nuevos y viejos desafíos. Buenos Aires: La Crujía, 2012.

BLAUSTEIN, David; DAICICH, Osvaldo. La Cocina: en el medio hay una ley . [S.l: s.n.]. Disponível em: <https://www.youtube.com/watch?v=D_XqqHY_zFk>. Acesso em: 5 maio 2015. , 2011

BOLAÑO, César. Qual a lógica das políticas de comunicação no Brasil? São Paulo: Paulus, 2007. .

BOLÍVIA, Estado Plurinacional De. Ley nº 0164 General de Telecomunicaciones, Tecnologías de Información y Comunicación . [S.l: s.n.]. Disponível em: <http://bit.ly/leyol64>. Acesso em: 3 abr. 2014. , 2011

BORELLO, José. Industrias culturales, innovación y formas de organización en un país semi-industrializado: El caso de la producción audiovisual en la Argentina. In: CONFERÊNCIA INTERNACIONAL LALICS 2013, 2013, Rio de Janeiro. Anais... Rio de Janeiro: LALICS, 2013. p.87-112. Disponível em: <http://www.redesist.ie.ufrj.br/lalics/papers/84_Industrias_culturales_innovacion_y_formas_de_organizacion_en_un_pais_semi_industrializado_El_caso_de_la_produccion_audiovisual_en_la_Argentina.pdf>.

BORGES, Gabriela. Parâmetros de qualidade para a análise de programas televisivos de âmbito cultural: uma proposta teórico-metodológica. Revista do NP em Comunicação Audiovisual da Intercom v. 1, n. l, p. 173-192, 2008.

BORRELLI, Marcelo. Clarín frente a los años de Videla y Martínez de Hoz (1976-1981). Entre el apoyo político y la objeción económica. Cuadernos de H Ideas v. 6, n. 6, 2012.

BRANDALISE, Roberta. A televisão brasileira nas fronteiras do Brasil com o Paraguai, a Argentina e o Uruguai. Um estudo sobre como as representações televisivas participam da articulação das identidades culturais no cotidiano fronteiriço. text - Universidade de São Paulo, 2011. Disponível em: <http://www.teses.usp.br/teses/disponiveis/27/27154/tde-26092011-114307/>. Acesso em: 13 ago. 2018.

BRANDÃO, Carlos. Território e desenvolvimento: as múltiplas escalas entre o local e o global. Campinas: Editora da Unicamp, 2007. .

BRANDT, João. Políticas nacionais de radiodifusão (1985-2001) e espaço público: estudos para uma aproximação crítica. Monografia - ECA/USP, São Paulo, 2002.

BULLA, Gustavo. Participación: concepto clave en la Ley de Servicios de Comunicación Audiovisual. In: BARANCHUK, Mariana; RODRÍGUE, Javier (Orgs.). . Ley 26.522: hacia un nuevo paradigma en comunicación. Argentina: UNLZ, 2011.

BUSSO, Nestor. La Cocina de la Ley: el proceso de incidencia en la elaboración de la Ley de Servicios de Comunicación Audiovisual em Argentina . [S.l.]: FARCO. Disponível em: <http://www.villamanuelita.org/lacocina/La\%20Cocina\%20de\%20la\%20Ley\%20.pdf>. Acesso em: 4 jan. 2015. , 2011 
BUSSO, Nestor. Políticas de Comunicación en el gobierno de Macri . Universidad Nacional de Comahue: [s.n.]. Disponível em: <https://www.youtube.com/watch?v=eknFbYILHyw>. , 8 maio 2017

CABALLERO, Francisco Sierra. Comunicación y intervencionismo en América Latina. Marco histórico estructural. In: CABALLERO, Francisco Sierra (Org.). . Golpes mediáticos: teoría y análisis de casos en América Latina. Quito: CIESPAL, 2016.

CABRAL FILHO, Adilson; COSTA, Paula Silveira Rosa Mota. A construção recente das Políticas de Comunicação pelos movimentos sociais no Brasil. Commons. Revista de Comunicación y Ciudadanía Digital v. 3, n. 1, 2014. Disponível em: <http://revistas.uca.es/index.php/cayp/article/view/3074>. Acesso em: 26 fev. 2018.

CALCAGNO, Natalia. Medios y fines. Disponível em: <http://www.paginal2.com.ar/diario/laventana/26104556-2008-05-21.html>. Acesso em: 18 jun. 2016.

CALICCHIO, Pascual. Ley de Servicios de Comunicación Audiovisual: problemas y desafíos de las televisoras populares. In: VINELLI, Natalia (Org.). . Comunicación y televisión popular: escenarios actuales, problemas y potencialidades. Buenos Aires: Cooperativa Gráfica El Río Suena, 2011.

CALIFANO, Bernadette. Comunicación se escribe con K: la radiodifusión bajo el gobierno de Néstor Kirchner. In: MASTRINI, Guillermo (Org.). Mucho ruido, pocas leyes: economia y políticas de comunicación en la Argentina (1920-2007). Buenos Aires: La Cruija, 2009.

CALIFANO, Bernadette. Políticas de medios y tecnologías de la información: de Argentina Digital a las modificaciones de Cambiemos. In: LABATE, Cecilia; ARRUETA, César (Orgs.). . La comunicación digital: redes sociales, nuevas audiencias y convergencia: desafíos y oportunidades para la industria, el Estado y los usuarios. San Salvador de Jujuy: Editorial de la Universidad Nacional de Jujuy, 2017.

CAMPOS, Rogério. Todas son noticias viejas: la parcialidad de los medios de comunicación en Brasil. In: CABALLERO, Francisco Sierra (Org.). . Golpes mediáticos: teoría y análisis de casos en América Latina. Quito: CIESPAL, 2016.

CANEDO, Daniela; LOIOLA, Elisabeth; PAUWELS, Caroline. Recam e a política cinematográfica do Mercosul: promoção da integração regional e da diversidade cultural? Políticas Culturais em Revista v. 1, n. 8 , 2015.

CARBONI, Ornela; LABATE, Cecilia. Políticas de comunicación para la producción de contenidos en la Televisión Digital Abierta en Argentina. In: IV ENCONTRO NACIONAL DA ULEPICC - BRASIL, 2012, Rio de Janeiro. Anais... Rio de Janeiro: Ulepicc, 2012. Disponível em: <http://www.rscomunica.com.br/ulepicc/pdf/gtı/CARBONI,_LABATE_politicas_de_comunicacion_para _la_produccion_de_contenidos_en_la_television_digital_abierta_en_argentina.pdf $>$. Acesso em: 17 jul. 2016.

CASA ROSADA. 7D. Aviso sobre la plena vigencia de la Ley de Medios (LSCA) a partir del 7 de diciembre. Disponível em: <http://bit.ly/video7d>.

CASANOVA, F. Director ejecutivo de la SIP: “La mejor ley de prensa es la que no existe”. Jornal. Disponível em: <http://diario.latercera.com/2014/10/20/o1/contenido/mundo/8-175752-9-director-ejecutivo-de-la-sip-lamejor-ley-de-prensa-es-la-que-no-existe.shtml>. Acesso em: 2 jul. 2016.

CASTELLS, Manuel. O poder da comunicação. São Paulo, Rio de Janeiro: Paz e Terra, 2015. .

CASTILLO, Ricardo. Mobilidade geográfica e acessibilidade: uma proposição teórica. GEOUSP: Espaço e Tempo (Online) v. 21, n. 3, p. 644-649, 2017a.

CASTILLO, Ricardo. Prefácio. In: LEANDRO SILVEIRA, Rogério; SOUZA, Mariana Barbosa (Orgs.). . Norma e território: contribuições multidisciplinares. Santa Cruz do Sul (SC): Edunisc, 2017b. 
CASTILLO, Ricardo. Reflexões sobre os sistemas técnicos orbitais. Experimental n. 1, p. 39-57, 1996.

CASTILLO, Ricardo. Sistemas orbitais e uso do território: integração eletrônica e conhecimento digital do território brasileiro. Tese (Doutorado em Geografia Humana) - Universidade de São Paulo, São Paulo, 1999. 343 p.

CASTRO, Alex. Elogio à liberdade de expressão. Disponível em: <http://cotuca.me/elogioliberdade> .

CAZZANIGA, Hernán. Entrevista de Hernán Cazzaniga ao autor, em novembro de 2016 em Posadas (Misiones, Argentina). . [S.l: s.n.]. , nov. 2016

CHARRAS, Diego De; BALADRÓN, Mariela. Una mirada sobre la sentencia que confirmó la constitucionalidad de la Ley de Servicios de Comunicación Audiovisual (LSCA) en Argentina. Chasqui. Revista Latinoamericana de Comunicación v. 0, n. 127, p. 37-47, 1 dez. 2014.

CHARRAS, Diego De; LOZANO, Luis; ROSSI, Diego. Ciudadanía(s) y derecho(s) a la comunicación. In: MASTRINI, Guillermo; BIZBERGE, Ana; CHARRAS, Diego De (Orgs.). . Las políticas de comunicación en el siglo XXI: nuevos y viejos desafíos. Buenos Aires: La Crujía, 2012.

CHESNAIS, François (Org.). A mundialização financeira. São Paulo: Xamã, 1998. .

CHESNAIS, François. Tobin or not Tobin? São Paulo: Ed. Unesp: ATTAC, 1999. .

CICCOLELLA, Pablo. Globalización y dualización en la región metropolitana de Buenos Aires. Grandes inversiones y reestructuración socioterritorial en los años noventa. EURE - Revista de Estudios Urbano Regionales v. 25, n. 76, p. 5-27, 1999.

CICCOLELLA, Pablo; VECSLIR, Lorena. Dinámicas, morfologías y singularidades en la reestructuración metropolitana de Buenos Aires. Revista Iberoamericana de Urbanismo n. 8, p. 23-41, 1 set. 2012.

CIN. RENAU - Red Nacional Audiovisual Universitaria. Disponível em: <http://www.renau.edu.ar>. Acesso em: 6 jan. 2018.

CLARÍN. Clarín en el mercado argentino. Disponível em: <http://bit.ly/videoclarinmercado>.

CLARÍN. Las relecturas audiovisuales. Disponível em: <http://www.clarin.com/cultura/San_Martin-audiovisuales-zamba-pakapaka_o_1412859129.html>. Acesso em: 21 jul. 2016.

CLARÍN. Ley de Medios: del slogan a la realidad. Disponível em: <http://bit.ly/videoclarinslogan>.

CLARÍN. Ley de medios: los artículos denunciados por inconstitucionales. Disponível em: <http://bit.ly/videoclarinarticulos>.

COALICIÓN POR UNA RADIODIFUSIÓN DEMOCRÁTICA. 21 puntos básicos por el derecho a la comunicación . [S.l.]: Coalición por una Radiodifusión Democrática. Disponível em: <http://www.telam.com.ar/advf/imagenes/especiales/documentos/2012/11/509435587ec92.pdf>. Acesso em: 27 jun. 2018. , 2004

COALICIÓN POR UNA RADIODIFUSIÓN DEMOCRÁTICA. Argentina: a dos años de la aprobación de la Ley de Servicios de Comunicación Audiovisual. In: LEÓN, Osvaldo (Org.). . Democratizar la palabra: movimientos convergentes en comunicación. Quito: ALAI, 2013.

COM, Sergio. Alfonsinismo, contexto sociopolítico y medios de comunicación. In: MASTRINI, Guillermo (Org.). . Mucho ruido, pocas leyes: economia y políticas de comunicación en la Argentina (1920-2007). Buenos Aires: La Cruija, 2009. 
CONSEJO ASESOR TDA. Reglamento operativo para la implementación y administración de los Centros Públicos de Producción Audiovisual (CEPA) del subprograma para el desarrollo de polos de investigación y perfeccionamiento de tecnologías audiovisuales digitales del plan operativo de fomento y promoción de contenidos audiovisuales digitales del SATVD-T. . [S.l.]: Consejo Asesor del SATVD-T. , 2013

CONTEL, Fábio. A internalização da categoria informação na geografia econômica: da teoria da localização à escola de geografia sueca. In: VIDEIRA, S. L.; COSTA, P. A.; FAJARDO, S. (Orgs.). . Geografia econômica: (re)leituras contemporâneas. Rio de Janeiro: Letra Capital, 2011.

CÓRDOBA, Liliana. La Coalición por una radiodifusión democrática: regeneración del espacio público y ejercicio de ciudadanía. Argumentos. Revista de Critica Social v. 0, n. 13 , 10 nov. 2011. Disponível em: <http://publicaciones.sociales.uba.ar/index.php/argumentos/article/view/890>. Acesso em: 15 jan. 2018.

COSPITO, Giuseppe. Hegemonia. In: LIGUORI, Guido; VOZA, Pascuale (Orgs.). . Dicionário gramsciano (1926-1937). São Paulo: Boitempo Editorial, 2017.

CRETTAZ, José. El Enacom archivó todos los planes de adecuación a la ley de medios. La Nación Buenos Aires, 2 fev. 2016 Disponível em: <https://www.lanacion.com.ar/1867583-el-enacom-archivo-casi-todos-losplanes-de-adecuacion-a-la-ley-de-medios>. Acesso em: 1 jul. 2018.

CRETTAZ, José. Próximo paso: la convergencia digital. La Nación Buenos Aires, 23 dez. 2015 Disponível em: <https://www.lanacion.com.ar/1856720-proximo-paso-la-convergencia-digital>. Acesso em: 10 jul. 2018.

CSJN. Grupo Clarín SA y otros c/ Poder Ejecutivo Nacional s/ acción meramente declarativa . [S.l: s.n.]. Disponível em: <https://www.cij.gov.ar/nota-12394-La-Corte-Suprema-declar--la-constitucionalidad-de-la-Leyde-Medios.html>. Acesso em: 2 set. 2018. , 2013

DA SILVEIRA, Sérgio Amadeu. Espectro aberto e mobilidade para a inclusão digital no Brasil. Comunicação e mobilidade n. 37 , 2009. Disponível em: < https://repositorio.ufba.br/ri/bitstream/ufba/166/4/Comunicacao\%20e\%20mobilidade.pdf\#page=39>. Acesso em: 17 jun. 2018.

DANTAS, Marcos. Informação e trabalho no capitalismo contemporâneo. Lua Nova n. 60, p. 5-44 , 2003.

DARDOT, Pierre; LAVAL, Christian. A nova razão do mundo: ensaios sobre a sociedade neoliberal. São Paulo: Boitempo, 2016. (Coleção Estado de Sítio). .

DEBANDE, O; CHERIT, G. The European Audiovisual Industry: an Overview. Eib Sector Papers , 2001.

DEL NEGRO, Rodolfo Leonel. Industria espacial y geopolítica. El caso de ARSAT. In: IX JORNADAS DE SOCIOLOGÍA DE LA UNLP, 2016, Ensenada. Anais... Ensenada: UNLP, 2016. p.17.

DIAS, Leila Christina. Redes de Informação, grandes organizações e ritmos de modernização. v. 1, p. 4, 2007.

DÍAZ, Cecilia Beatriz. La restauración concentradora de cambiemos. La disputa simbólica en contra de la democratización de la comunicación. In: IX JORNADAS DE SOCIOLOGÍA DE LA UNLP, 2016, La Plata. Anais... La Plata: UNLP, 2016. Disponível em:

<http://www.memoria.fahce.unlp.edu.ar/trab_eventos/ev.9300/ev.9300.pdf>.

DOLLFUS, Olivier. Geopolítica do Sistema-Mundo. In: SANTOS, Milton; ET AL (Orgs.). . Fim de século e Globalização. São Paulo: Hucitec: Anpur, 2002.

DOLLFUS, Olivier. O Espaço Geográfico. Rio de Janeiro: Bertrand Brasil, 1991. .

DOMINGUES DA SILVA, Juliano M. Atores, interesses e processo decisório: o caso da TV digital brasileira. In: IV ENCONTRO DA COMPOLÍTICA, 2011, Rio de Janeiro. Anais... Rio de Janeiro: UERJ, 2011. p.22. 
DOMINGUES DA SILVA, Juliano M. Técnicas para Medir Concentração de Mercado de Mídia: modo de usar. In: XVIII CONGRESSO DE CIÊNCIAS DA COMUNICAÇÃO NA REGIÃO NORDESTE, 2016, Caruaru (PE). Anais... Caruaru (PE): Intercom, 2016. Disponível em: <http://www.portalintercom.org.br/anais/nordeste2016/resumos/R52-1663-1.pdf>. Acesso em: 9 set. 2018.

DORFMAN, Ariel; MATTELART, Armand. Para ler o Pato Donald: Comunicação de massa e Colonialismo. São Paulo: Paz e Terra, 2010. .

DUCATENZEILER, Claudia. Entrevista de Claudia Ducatenzeiler ao autor, em dezembro de 2016 em Buenos Aires. . [S.l: s.n.]. , nov. 2016

DUEK, Carolina et al. Representaciones de la ludicidad en el bicentenario: acerca de "La asombrosa excursión de José Zamba". In: IX JORNADAS DE SOCIOLOGÍA UBA, 2011, Buenos Aires. Anais... Buenos Aires: UBA, 2011. p.13.

EBC. Televisão de qualidade. Disponível em: <http://tvbrasil.ebc.com.br/vertv/episodio/televisao-de-qualidade>. Acesso em: 18 jul. 2016.

ECUADOR, Gobierno Del. Ley Orgánica de Comunicación . [S.l: s.n.]. Disponível em: <http://bit.ly/ecleycom>. Acesso em: 3 abr. 2014. , 2013

ENACOM. Informe - Acceso a internet fija - 3er Trimestre 2017 . [S.1.]: Enacom. Disponível em: <https://www.enacom.gob.ar/multimedia/noticias/archivos/201712/archivo_20171211074252_4575.pdf>., 2017

ENACOM. Resolución 10090 - E/2016. , 29 dez. 2016 . Disponível em: <https://www.boletinoficial.gob.ar/DetalleNorma/157349>. Acesso em: 2 set. 2018.

ENCUENTRO. Desguace en la Televisión Digital Abierta, TDA. Alerta de los trabajadores. Disponível em: $<$ http://radioencuentro.org.ar/19257/>. Acesso em: 2 set. 2018.

ESPADA, Augustín. Una oportunidad perdida: la ley y los medios sin fin de lucro. In: MASTRINI, Guillermo; BECERRA, Martín (Orgs.). . Medios en guerra: Balance, crítica y desguace de las políticas de comunicación 2003-2016. Buenos Aires: Biblos, 2017.

ESPADA, Augustín; MARINO, Santiago. ¿Cómo usó la publicidad oficial Macri en su primer año? Disponível em: <https://chequeado.com/el-explicador/como-uso-la-publicidad-oficial-macri-en-su-primer-ano/>. Acesso em: 2 set. 2018.

ESPERÓN, Carlos Rodríguez; VINELLI, Natalia. Desarmando espejismos. In: VINELLI, Natalia; ESPERÓN, Carlos Rodríguez (Orgs.). . Contrainformación: medios alternatvios para la acción política. Buenos Aires: Continente, 2004.

EVASO, Alexander Sergio. O espaço vertiginoso. text - Universidade de São Paulo, 2007. Disponível em: <http://www.teses.usp.br/teses/disponiveis/8/8136/tde-01062007-123512/>. Acesso em: 14 jul. 2018.

FALKHEIMER, Jasper; JANSSON, André. Geographies of communication: the spatial turn in media studies. Nordicom: Goteborg, 2006. Goteborg: Nordicom, 2006.

FANON, Frantz. Os Condenados da Terra. Lisboa: Ulisseia, 1961. .

FEIDER, Frank. El Plan Argentina Conectada, observadas en tanto política nacional de comunicación. In: CONIE 2015 - INNOVACIÓN EN EL ESTADO: INSTRUMENTO DEL DESAROLLO, 2015, Resistencia. Anais... Resistencia: [s.n.], 2015. Disponível em: <http://conie.chaco.gov.ar/publicaciones_electronicas/trabajos/3.36.pdf>. Acesso em: 21 jul. 2016. 
FEIDER, Frank; GALANTERNIK, Violeta; INGARAMO, Catalina Meza. Argentina Conectada. Un acercamiento a las formas emergentes de intervención estatal en el campo de las telecomunicaciones. Hipertextos v. 1, n. 0 , 2013. Disponível em: <http://revistahipertextos.org/wp-content/uploads/2015/12/Hipertextos-no.-4-1.pdf\#page=167>. Acesso em: 21 jul. 2016.

FEINMANN, José Pablo. Filosofía política del poder mediático. Buenos Aires: Planeta, 2013. .

FREIRE, Paulo. Extensão ou comunicação? Rio de Janeiro: Paz e Terra, 2011. .

GALEANO, Eduardo. De pernas pro ar: a escola do mundo ao avesso. Porto Alegre: L\&PM Editores, 2011. .

GALPERIN, Hernán. El dividendo digital y el futuro de la radiodifusión en América Latina . [S.l.]: UDESA Documentos de Trabajo. Disponível em: <https://www.udesa.edu.ar/sites/default/files/importedeb63130551585a96c22f7b53408f55a91964a882-03dividendo_digital_hg.pdf>. Acesso em: 1 abr. 2017. , 2007

GARCÍA LINERA, Álvaro. La potencia plebeya: acción colectiva e identidades indígenas, obreras y populares en Bolivia. Bogotá: Siglo del Hombre Editores y CLACSO, 2009. .

GARCÍA, Marcos et al. Venezuela: Ley de Responsabilidad Social de Radio y Televisión. In: MASTRINI, Guillermo; CARBONI, Ornela (Orgs.). . Siete debates nacionales en políticas de comunicación: actores, convergencia y tecnologia. Bernal: Universidad Nacional de Quilmes Editorial, 2012.

GARCÍA VARGAS, Alejandra. Dinámica territorial del subprograma de Polos y Nodos para el SATVD-t. Selección de informes y registros del Polo NOA / cabecera UNJu (2011-2014) . [S.l.]: SIMEL NOA - Facultad de Ciencias Económicas y Facultad de Humanidades y Ciencias Sociales - UNJu. , 2015

GARCÍA VARGAS, Alejandra; BURGOS, Ramón. El puente y las piedras. Rearticulación del espacio audiovisual en el Programa de Polos y Nodos Audiovisuales del Sistema Argentino de Televisión Digital Terrestre: el caso del Nodo Jujuy. In: XII CONGRESO IBERCOM, 2011, Santa Cruz de la Sierra. Anais... Santa Cruz de la Sierra: Ibercom, 2011. Disponível em:

<http://www.imultimedia.pt/ibercom/comunicacoes/ibercom2011/comunica_ibercom_en_pdf/Ponencias\%20GT5\%20Com\%20Audiovisual/Ponencia\%20GT5\%20Garc\%25eda\%20y\%20Burgos.pdf>. Acesso em: 27 jul. 2018.

GENNARI, Marcos; LAPUENTE, Sofía. El Arsat-1 y su vinculación con la Televisión Digital Abierta como política pública promovedora de inclusión social. Actas de Periodismo y Comunicación v. 1, n. 2 , 3 maio 2016. Disponível em: <http://www.perio.unlp.edu.ar/ojs/index.php/actas/article/view/3263>. Acesso em: 13 jul. 2018.

GÓMEZ, Ava; RAMOS-MARTÍN, Juan. Legislación y medios comunitarios. Análisis comparativo de Bolivia y Venezuela. Palabra Clave v. 17, n. 2 , 2014.

GÓMEZ GERMANO, Gustavo et al. En pocas manos: mapa de la concentración de los medios de comunicación en Uruguay. Montevidéu: FES, 2017. .

GÓMEZ GERMANO, Gustavo. Gobiernos progresistas y políticas públicas de comunicación: una aproximación regional para provocar la reflexión. In: KOSCHÜTZKE, Alberto; GERBER, Elisabet (Orgs.). . Progresismo y políticas de comunicación: manos la a obra. Buenos Aires: Fundación Friedrich Ebert, 2011.

GÓMEZ GERMANO, Gustavo. La regulación democrática de los medios de comunicación. Necesidad, alcances y límites de la intervención estatal. La democratización de la comunicación y la información en América Latina. Quito: CIESPAL, Carter Center, 2013.

GOMEZ, Rodolfo. Políticas públicas de comunicación y Estados capitalistas en América Latina: una interpretación desde tres teorías (del Estado, de la comunicación y del conflicto social). In: DANTAS, MARCOS (Org.). . Avances en los procesos de democratización de la comunicación en América Latina. Buenos Aires: CLACSO, 2013. 
GONÇALVES, Mírian (Org.). Enciclopédia do golpe, vol 2. - O papel da mídia. Bauru (SP): Canal 6, 2018. .

GONZALEZ, Leonardo; GARCÍA GERMANIER, Fernanda. El proceso de creación de contenidos en los Polos Audiovisuales Tecnológicos. Tram [p] as de la Comunicación y la Cultura , 2014. Disponível em: <http://sedici.unlp.edu.ar/handle/10915/42180>. Acesso em: 13 jul. 2016.

GONZALEZ, Leonardo; NOVOMISKY, Sebastian. La televisión digital en Argentina. Cambios políticos, tecnológicos y económicos. Miradas desde una perspectiva federal. El caso del canal para niños PAKAPAKA. In: SOUZA, María Dolores; CABELLO, Patricio; VALLE, Carlos Del (Orgs.). . Medios, Edades y Cultura. Temuco (Chile): UFRO, 2012.

GONŹALEZ, Leonardo; PAULONI, Silvina; CODONI, María Florencia. De dónde viene y hacia dónde va la televisión educativa, cultural y pública en la Argentina. p. 13,2016.

GONZÁLEZ, Néstor Daniel. Ataques a la televisión digital. Derechos en riesgo. Actas de Periodismo y Comunicación v. 2, n. 1, 2016.

GONZÁLEZ, Néstor Daniel. La Televisión Digital Argentina a dos años del apagón. Retrocesos e incertidumbres. In: 6A JORNADAS DE APLICACIONES Y USABILIDADE DE LA TELEVISIÓN DIGITAL INTERACTIVA, 2017, Aveiro, Portugal. Anais... Aveiro, Portugal: Universidade de Aveiro, 2017.

GONZÁLEZ, Néstor Daniel; CARABALLO, Cristian. La Televisión Digital en Argentina a cinco años de su puesta en marcha. In: ALAIC 2014, 2014, Peru. Anais... Peru: PUCP, 2014. p.23.

GORZ, André. O imaterial: conhecimento, valor e capital. São Paulo: Annablume, 2005. .85-7419-489-1.

GOTTMANN, Jean. Megalopolis and antipolis: the telephone and the structure of the city. In de Sola Pool. Cambridge, MA: MIT Press, 1977. .

GRZINCICH, Claudia Guadalupe; ALANIZ, María. Televisión Digital. Una aproximación al caso argentino y su alcance en países de la región (2009-2015). In: X CONGRESO INTERNACIONAL DE LA UNIÓN LATINA DE ECONOMÍA POLÍTICA DE LA INFORMACIÓN, LA COMUNICACIÓN Y LA CULTURA (ULEPICC-2017), 2017a, Quito. Anais... Quito: CIESPAL, 2017. Disponível em: <https://rdu.unc.edu.ar/handle/11086/5739>. Acesso em: 8 jul. 2018.

GRZINCICH, Claudia Guadalupe; ALANIZ, María. TV Digital Argentina: Políticas públicas y regulación en el contexto suramericano (2009-2015). In: V JORNADAS INTERNACIONALES DE PROBLEMAS LATINOAMERICANOS: “LOS MOVIMIENTOS SOCIALES FRENTE A LA RESTAURACIÓN NEOLIBERAL: RESISTENCIAS, OPOSICIÓN Y RE-CONSTRUCCIÓN DE PERSPECTIVAS TEÓRICO-POLÍTICAS EMANCIPATORIAS", 2017b, Córdoba. Anais... Córdoba: Universidad Nacional de Córdoba, 2017. Disponível em: <https://rdu.unc.edu.ar/handle/11086/5740>. Acesso em: 10 jun. 2018.

GUIDO, Luciana; VERSINO, Mariana. Las políticas públicas en la constitución de las redes de información y comunicación en la Argentina reciente (1995-2015). Questión v. nº 51 , set. 2016. Disponível em: <http://hdl.handle.net/10915/56065>. Acesso em: 13 jul. 2018.

GUTIÉRREZ, Nayla Berenice. Almacenamiento y distribución de producciones audiovisuales argentinas en Internet: los casos de Contenidos Digitales Abiertos y Cinema Argentino. Question v. 1, n. 49, p. 478-487, 28 mar. 2016.

HÄGERSTRAND, Torsten. A propagação de ondas de inovação. Boletim Campineiro de Geografia v. 3, n. 2 , 2013.

HARVEY, David. A arte de lucrar: globalização, monopólio e exploração da cultura. In: MORAES, Dênis De (Org.). . Por uma outra comunicação: mídia, mundialização cultural e poder. Rio de Janeiro: Record, 2010. 
HENKEL, Cristian; MORCILLO, Julián. La palabra liberada: una crítica marxista a la ley de medios. Buenos Aires: Eudeba, 2014. .

HEPWORTH, M. Geography of the information economy. London: Guilford, 1989. .

HERNÁNDEZ PRIETO, Marina; PÉREZ ALAEJOS, María de la Peña. Análisis del proceso de elaboración, sanción e implementación de la Ley de Servicios de Comunicación Audiovisual 26.522. El desinfle de un ideal. Communication \& Society v. 30, n. 2, p. 131-147 , 2017.

HILLIS, Ken. On the margins: the invisibility of communications in geography. Progress in Human Geography v. 22, n. 4, p. 543-566, 1 ago. 1998.

HURTADO, Diego; BIANCHI, Matías Diego; LAWLER, Diego. Tecnología, políticas de Estado y modelo de país: el caso ARSAT, los satélites geoestacionarios versus "los cielos abiertos". Epistemología e Historia de la Ciencia v. 2, n. 1, p. 48-71, 30 nov. 2017.

IAAVIM. IAAVIM - Programas. Disponível em: <https://iaavim.misiones.gob.ar/?page_id=3068>. Acesso em: 1 fev. 2018

IANNI, Octavio. Imperialismo e Cultura. Petrópolis (RJ): Vozes, 1979. .

IANNI, Octavio. O príncipe eletrônico. Perspectivas n. 22, p. 11-29 , 1999.

INCAA. Institucional - Autoridades . [S.l: s.n.]. Disponível em: <http://www.incaa.gov.ar/incaal>. Acesso em: 20 jul. 2018. , 2018

INDEC. Unidades Geoestadísticas - Cartografía y códigos geográficos del Sistema Estadístico Nacional. Disponível em: <https://www.indec.gov.ar/codgeo.asp>. Acesso em: 10 jul. 2018.

INDYMEDIA ARGENTINA. El rol de los medios alternativos. In: VINELLI, Natalia; ESPERÓN, Carlos Rodríguez (Orgs.). . Contrainformación: medios alternatvios para la acción política. Buenos Aires: Continente, 2004.

INTERNET ARCHIVE. Internet Archive: Digital Library of Free \& Borrowable Books, Movies, Music $\varepsilon$ Wayback Machine. Disponível em: <https://archive.org/>. Acesso em: 13 jul. 2018.

INTERVOZES. Informativo Intervozes TV Digital n. 2 . [S.l.]: Intervozes. Disponível em: <http://intervozes.org.br/arquivos/intermanoozitvddae.pdf>. Acesso em: 16 jun. 2018a. , maio 2006

INTERVOZES. Julio quer saber . [S.l: s.n.]. Disponível em: <https://www.youtube.com/watch?v=PaDIogzTECs>. Acesso em: 28 ago. 2018a. , 2017

INTERVOZES. Monitoramento da Propriedade da Mídia no Brasil (Media Ownership Monitor Brasil) 2017. [S.l.]: Repórteres Sem Fronteiras; Intervozes. Disponível em: <http://quemcontrolaamidia.org.br>. Acesso em: 3 nov. 2017b. , 2017

INTERVOZES. TV Digital: Princípios e Propostas para uma Transição Baseada no Interesse Público . [S.l.]: Intervozes. Disponível em: <http://intervozes.org.br/publicacoes/tv-digital-principios-e-propostas-parauma-transicao-baseada-no-interesse-publico/>. Acesso em: 16 jun. 2018b. , 2006

INWOOD, Michael. Dicionário Hegel. Rio de Janeiro: Jorge Zahar Ed., 1997. .

ISNARD, Hildebert. O espaço do geógrafo. Boletim Geográfico v. 36, n. 258-259, p. 5-16 , 1978.

ISNARD, Hildebert. O Espaço Geográfico. Coimbra: Almedina, 1982. . 
ITURRALDE, María Eugenia. La descentralización como elemento fundamental en el proceso de democratización de los medios de comunicación en Argentina. Questión: Revista Especializada en Periodismo y Comunicación v. 1, n. 47, p. 162-175, 2015.

KAHIL, Samira. Psicosfera: uso corporativo da esfera técnica do território e o novo espírito do capitalismo. Sociedade \& Natureza v. 22, n. $3,2010$.

KRAKOWIAK, Fernando. Asoma el plan McKinsey para las comunicaciones. Página/12 Buenos Aires, 13 jun. 2016 Disponível em: <https://www.paginal2.com.ar/diario/economia/2-301612-2016-06-13.html>. Acesso em: 30 abr. 2018Economia.

KRAKOWIAK, Fernando. Un regalo para los radiodifusores: Enacom les asignó el dividendo digital de la banda VHF. Página 12 Buenos Aires, 6 out. 2017 Disponível em: <https://www.paginal2.com.ar/12714-unregalo-para-los-radiodifusores>. Acesso em: 28 jun. 2018Economía.

KRAKOWIAK, Fernando; MASTRINI, Guillermo; BECERRA, Martín. Argentina: razões geopolíticas e perspectivas econômicas Google-Books-ID: 36RhCgAAQBAJ. In: ALBORNOZ, Luis A.; LEIVA, Maria Trindad García (Orgs.). . A Televisão Digital Terrestre: Experiências nacionais e diversidade na Europa, América e Ásia. Lisboa: Media XXI, 2014. 978-989-729-068-8.

LA NACIÓN. Lanata: “AA dónde voy a ir si no es al Grupo Clarín?” La Nación 5 jan. 2012a Disponível em: <https://www.lanacion.com.ar/1437760-lanata-a-donde-voy-a-ir-si-no-es-al-grupo-clarin>. Acesso em: 19 ago. 2018.

LA NACIÓN. Mirá un adelanto del especial del Bicentenario de Zamba. La Nación 7 ago. 2016 Disponível em: <http://www.lanacion.com.ar/1916155-vuelve-zamba-el-mismo-personaje-animado-pero-sin-maniqueismos>. Acesso em: 21 jul. 2016.

LA NACIÓN. Un dibujito de Paka Paka cuenta la "historia oficial" en versión infantil. La Nación 8 mar. $2012 b$ Disponível em: <http://www.lanacion.com.ar/1495635-zamba-de-paka-paka-relata-la-historia-oficial-enversion-infantil>. Acesso em: 21 jul. 2016.

LABATE, Cecilia. La TV pública argentina hacia la convergencia digital: implementación de políticas durante el gobierno de Mauricio Macri. In: BALDESSAR, Maria José; MONJE, Daniela Inés (Orgs.). . Diálogos latino-americanos: comunicação e democracia em tempos de convergência. São Paulo: Intercom, 2018.

LABATE, Cecilia. Los medios estatales en la era digital: entre la convergencia de pantallas y la divergencia de las políticas de comunicación. In: MARINO, Santiago (Org.). . El audiovisual ampliado: políticas públicas, innovaciones del mercado y tensiones regulatorias en la industria de la televisión argentina frente a la convergencia. Buenos Aires: Ediciones Universidad del Salvador, 2016.

LABATE, Cecilia; CARBONI, Ornela. Hacia la producción de contenidos audiovisuales para la TDT en Argentina. Revista Latinoamericana de Ciencias de la Comunicación v. 9, n. 16 , 11 mar. 2014. Disponível em: <http://www.alaic.org/revistaalaic/index.php/alaic/article/view/478>. Acesso em: 17 jul. 2016.

LAMAC. As metricas da TV por Assinatura. Disponível em: <http://www.lamac.org/pt/as-metricas-da-tv-porassinatura>. Acesso em: 11 abr. 2018.

LAMAS, Ernesto; LEWIN, Hugo. Aproximación a las radios de nuevo tipo: Tradición y escenarios actuales. Causas y azares v. 2, n. 2, p. 70-86, 1995.

LAN, Diana; MIGUELTORENA, Diana. Aportes para el estudio de ciudades intermedias de Argentina. In: MATURANA, Francisco et al. (Orgs.). . Sistemas urbanos y ciudades medias en Iberoamérica. Santiago de Chile: LOM, 2017.

LARA, Glauciene Diniz. Desconcentração na comunicação audiovisual argentina: três anos de tensões pela implementação da Lei de Meios. Dissertação (Mestrado em Comunicação) - UNB, Brasília, 2013. 344 p. Disponível em: <http://repositorio.unb.br/bitstream/10482/13894/1/2013_GlaucieneDinizLara.pdf>. 
LATINOBARÓMETRO. Latinobarómetro 2009 - Análisis de Resultados en línea. Disponível em: $<$ http://www.latinobarometro.org/latino/LATAnalize.jsp>. Acesso em: 6 jun. 2011.

LAZZARO, Luis. La batalla de la comunicación: de los tanques mediáticos a la ciudadanía de la información. Buenos Aires: Colihue, 2010.

LEANDRO RIBEIRO, Luis Henrique. Território e macrossistema de saúde : os programas de fitoterapia no Sistema Único de Saúde (SUS). , 2015. Disponível em: <http://repositorio.unicamp.br/jspui/handle/REPOSIP/287778 >. Acesso em: 20 ago. 2018.

LED, Fundación. Análisis comparativo sobre Leyes de Servicios de Comunicación Audiovisual de Argentina, Venezuela, Ecuador, Bolivia, Perú y Anteproyecto de Ley de Uruguay . [S.l.]: LED. Disponível em: <http://bit.ly/fled2013>. Acesso em: 3 abr. 2014. , 2013

LEIVA. María Trinidad García. El dividendo digital: desafíos, oportunidades y posiciones nacionales. [S.1.]: Revista Latina de Comunicación Social, 2009a. Disponível em: <http://www.revistalatinacs.org/o9/art/35_834_37_ULEPICC_19/Trinidad_Garcia_Leiva.html>. Acesso em: 5 jul. 2018.

LEIVA, María Trinidad García. El futuro del espectro radioeléctrico: entre las políticas de comunicación y el mercado. In: MASTRINI, Guillermo; BIZBERGE, Ana; CHARRAS, Diego De (Orgs.). . Las políticas de comunicación en el siglo XXI: nuevos y viejos desafíos. Buenos Aires: La Crujía, 2012.

LEIVA, María Trinidad García. Fin de milenio: concentración, continuidad y control. Una mirada sobre las políticas de radiodifusión del gobierno de Fernando de la Rua. In: MASTRINI, Guillermo (Org.). . Mucho ruido, pocas leyes: economia y políticas de comunicación en la Argentina (1920-2007). Buenos Aires: La Cruija, 2009b.

LEMOS, Amalia Inés Geraiges De. América Latina: à procura de uma geografia mestiça. In: LEMOS, Amalia Inés Geraiges De; SILVEIRA, María Laura; ARROYO, Mónica (Orgs.). . Questões territoriais na América Latina. Buenos Aires: CLACSO, 2006.

LENCIONI, Sandra. Região e Geografia. São Paulo: Edusp, 2009. .

LEROY, Felipe. A indústria do audiovisual no Brasil: uma análise a partir de dados cross-section e longitudinais. Tese (Doutorado em Economia) - UFMG, Belo Horizonte, 2013.

LÉVY, Jacques. Entrevista. Boletim Campineiro de Geografia v. 4, n. 2 , 2014.

LÉVY, Jacques. Réinventer la France: trente cartes pour une nouvelle géographie. Paris: Fayard, 2013. .

LIMA, Venício De. A grande mídia e a segunda Confecom. Portal de notícias. Disponível em: <https://www.cartamaior.com.br/?/Editoria/Politica/A-grande-midia-e-a-segunda-Confecom/4/15413>. Acesso em: 7 jan. 2015.

LIMA, Venício De. Comunicação e cultura: as ideias de Paulo Freire. Brasília: UNB/Fundação Perseu Abramo, 2011a. .

LIMA, Venício De. Liberdade de expressão vs. liberdade de imprensa: direito à comunicação e democracia. São Paulo: Editora Publisher Brasil, 2010a. .

LIMA, Venício De. Onde o calo dói. Disponível em: <http://observatoriodaimprensa.com.br/interessepublico/onde-o-calo-doi/>. Acesso em: 26 fev. 2018b.

LIMA, Venício De. Política de Comunicações: o balanço dos governos Lula. Disponível em: <https://www.cartamaior.com.br/?/Coluna/Politica-de-Comunicacoes-o-balanco-dos-governos-Lula/22220>. Acesso em: 26 fev. 2018c. 
LIMA, Venício De. Regulação das comunicações. São Paulo: Paulus, 2011b. .

LIMA, Venício De; ARAÚJO, Bráulio Santos Rabelo De. Monopólio ou oligopólio? Contribuição ao debate. Disponível em: <https://www.cartamaior.com.br/?/Editoria/Midia/Monopolio-ou-oligopolio-Contribuicao-ao-debate/12/32621>. Acesso em: 15 jan. 2018.

LINARE, Cecilia; CUESTA, Virginia. Incursionando en el asombroso mundo de Zamba. p. 10 , 2015.

LINARES, Alejandro et al. Brechas: la desigualdad en las políticas de fomento de medios comunitarios, otros medios e industrias culturales. Revista Latinoamericana de Ciencias de la Comunicación v. 13, n. 25,12 abr. 2017. Disponível em: <https://www.alaic.org/revista/index.php/alaic/article/view/847>. Acesso em: 3 set. 2018.

LINARES, Alejandro. Público de Radiodifusión en la Ley de Servicios de Comunicación Audiovisual de Argentina - LSCA - (2009-2014). Revista Estado y Políticas Públicas n. 3, p. 156-170 , 2014.

LOJKINE, Jean. A revolução informacional. São Paulo: Cortez, 2002. .

LOMBARDINI, Mariana. Entrevista de Mariana Lombardini ao autor, em novembro de 2016 em Posadas (Misiones, Argentina). . [S.l: s.n.]. , nov. 2016

LONGO, Verónica et al. Regresión. Las nuevas políticas para medios comunitarios en Argentina. Logos v. 24, n. 1, 26 ago. 2017. Disponível em: <http://www.e-publicacoes.uerj.br/index.php/logos/article/view/28266>. Acesso em: 22 ago. 2018.

LORETI, Damián; CHARRAS, Diego De; LOZANO, Luis. Regresividad. Cómo pasar de un paradigma de derechos humanos a un modelo de negocios. In: CABALLERO, Francisco Sierra; CASTRO, Rosa Elena Vallejo (Orgs.). . Derecho a la Comunicación: Procesos regulatorios y democracia en América Latina. Quito: Ciespal, 2017.

LORETI, Damián; LOZANO, Luis. El derecho a comunicar: los conflitos en torno a la libertad de expresión en las sociedades contemporáneas. Buenos Aires: Siglo Veintiuno, 2014. .

LUKINBEAL, Chris; ZIMMERMANN, Stefan (Orgs.). The Geography of Cinema - A Cinematic World (Media Geography at Mainz). Stuttgart: Franz Steiner Verlag, 2008. .

MANSELL, Robin. ICTs, discourse and knowledge societies: implications for policy and practice. In: FRAUMEIGS, Divina et al. (Orgs.). . From NWICO to WSIS - 30 years of communication geopolitcs: actors and flows, structures and divides. Bristol (UK): Intellect, 2012.

MANZANAL, Mabel; ARZENO, Mariana. Conflictos territoriales en ámbitos rurales de la Argentina actual. GEOUSP: Espaço e Tempo (Online) n. 28, p. 197 , 30 ago. 2010.

MARIE, Jonathan. El OTT estatal gratuito CDA de Argentina sobrepasó los 6 millones de videos vistos. Disponível em: <http://nextvnews.com/el-ott-estatal-gratuito-cda-de-argentina-sobrepaso-los-6-millones-devideos-vistos/>. Acesso em: 13 jan. 2018.

MARÍN. Javier; CREUS. Ruben G.; GARCÍA ZABALLOS. Antonio. Informe de la situación de conectividad de internet y banda ancha en Argentina. [S.l.]: Inter-American Development Bank, 12 abr. 2013. Disponível em: <http://publications.iadb.org/handle/11319/5719>. Acesso em: 21 jul. 2016.

MARINGONI, Gilberto; GLASS, Verena. A regulação da mídia na América Latina. Desafios do Desenvolvimento n. $71,2012$.

MARINO, Santiago (Org.). El audiovisual ampliado: políticas públicas, innovaciones del mercado y tensiones regulatorias en la industria de la televisión argentina frente a la convergencia. Buenos Aires: Ediciones Universidad del Salvador, 2016a. . 
MARINO, Santiago. Fútbol y TV: volver al futuro. Revista Fibra n. 15,19 maio 2017a. Disponível em: <http://papel.revistafibra.info/futbol-tv-volver-al-futuro/>. Acesso em: 1 set. 2018.

MARINO, Santiago. La ley y las políticas: debate, acción y aplicación. In: MARINO, Santiago (Org.). . El audiovisual ampliado: políticas públicas, innovaciones del mercado y tensiones regulatorias en la industria de la televisión argentina frente a la convergencia. Buenos Aires: Ediciones Universidad del Salvador, 2016b.

MARINO, Santiago. Los claroscuros de las políticas de comunicación en torno a la ley audiovisual. In: MASTRINI, Guillermo; BECERRA, Martín (Orgs.). . Medios en guerra: Balance, crítica y desguace de las políticas de comunicación 2003-2016. Buenos Aires: Biblos, 2017b.

MARINO, Santiago. Medios: ¿y si crisis no es siempre oportunidad? Letra P , 17 nov. 2017c. Disponível em: <http://www.letrap.com.ar/nota/2017-11-17-20-11-2-medios-y-si-crisis-no-es-siempre-oportunidad>. Acesso em: 3 jan. 2018.

MARINO, Santiago. Políticas de comunicación del sector audiovisual: modelos divergentes, resultados equivalentes. Bernal: Universidad Nacional de Quilmes, 2017d. Disponível em: <http://unidaddepublicaciones.web.unq.edu.ar/wp-content/uploads/sites/46/2018/04/e-book-PoliticasdeComunicaciondelSectorAudiovisual-Marino.pdf>. Acesso em: 1 fev. 2018. .

MARINO, Santiago; GUIMERÀ ORTS, Josep Àngel. Televisión sin fines de lucro en la Argentina de la Ley Audiovisual: el caso de Barricada TV. Austral Comunicación v. 5, n. 2, p. 205-227, 15 dez. 2016.

MARINO, Santiago; MASTRINI, Guillermo; BECERRA, Martín. Argentina: el proceso de regulación democrática de la comunicación. In: KOSCHÜTZKE, Alberto; GERBER, Elisabet (Orgs.). . Progresismo y políticas de comunicación: manos la a obra. Buenos Aires: Fundación Friedrich Ebert, 2011.

MARINO, Santiago; MASTRINI, Guillermo; BECERRA, Martín. El proceso de regulación democrática de la comunicación em Argentina. Revista Oficios Terrestres n. 25, 2010.

MARIOTTO, Gabriel. Entrevista sobre LSCA e sua aplicação, o desmonte macrista e Fútbol para Todos. . [S.I: s.n.]. , 19 fev. 2016

MARTÍN-BARBERO, Jesús. Globalização comunicacional e transformação cultural. In: MORAES, Dênis De (Org.). . Por uma outra comunicação: mídia, mundialização cultural e poder. Rio de Janeiro: Record, 2010.

MARTÍN-BARBERO, Jesús. La comunicación plural. Paradojas y desafíos. Nueva sociedad n. 140 , 1995. Disponível em: <http://www.insumisos.com/lecturasinsumisas/Comunicacion\%20plural.pdf>. Acesso em: 20 jul. 2016.

MARTÍN-BARBERO, Jesús. Las transformaciones del mapa: identidades, industrias y culturas. In: GARRETÓN, Manuel Antonio (Org.). . América Latina: un espacio cultural en el mundo globalizado. Bogotá: Convenio Andrés Bello, 1999.

MARTÍNEZ, Sanjuana. Emperadores, imperios, decretos imperiales y alianzas en los medios informativos del mundo. Persistencia de algunos reductos republicanos. In: UNIÓN DE TRABAJADORES DE PRENSA DE BUENOS AIRES (Org.). . No hay democracia informativa sin democracia economica. Voces múltiples del Primer Congreso Mundial de la Comunicación - UTPBA. Buenos Aires: Ediciones UTPBA, 2001.

MARTINS, Helena. Comunicação: TV e rádio enfrentam novos e velhos desafios. Disponível em: <http://agenciabrasil.ebc.com.br/geral/noticia/2014-09/comunicacao-tv-e-radio-enfrentam-novos-e-velhos-desafios>. Acesso em: 4 jul. 2016.

MASSEY, Doreen. A mente geográfica. GEOgraphia v. 19, n. 40, p. 36 , 5 out. 2017. 
MASSEY, Doreen. Geometrías del poder y la conceptualización del espacio . Universidad Central de Venezuela, Caracas: [s.n.]. Disponível em: <http://iner.udea.edu.co/grupos/GET/Seminario_Geografia_Perla_Zusman/7-Massey.pdf>. Acesso em: 1 abr. 2018. , 17 set. 2007

MASTRINI, Guillermo et al. El Estado como protagonista del desarrollo de la TDT en Argentina. Cuadernos de informacion v. 31, p. 69-78, 5 dez. 2012.

MASTRINI, Guillermo et al. Televisión Digital: políticas públicas, expansión y consumos. In: MARINO, Santiago (Org.). . El audiovisual ampliado: políticas públicas, innovaciones del mercado y tensiones regulatorias en la industria de la televisión argentina frente a la convergencia. Buenos Aires: Ediciones Universidad del Salvador, 2016.

MASTRINI, Guillermo et al. Uso y consumo de la Televisión Digital Terreste en argentina. Un estudio en los municipios de San Fernando y Quilmes . [S.l.]: Universidad Nacional de Quilmes. Disponível em: <https://martinbecerra.files.wordpress.com/2014/og/estudio-tdt-argentina-icep-maestria-iicc-unq2014.pdf>. Acesso em: 21 jan. 2016. , 2014

MASTRINI, Guillermo; BECERRA, Martín (Orgs.). Medios en guerra: Balance, crítica y desguace de las políticas de comunicación 2003-2016. Buenos Aires: Biblos, 2017.

MASTRINI, Guillermo; BECERRA, Martín. Periodistas y Magnates. Estructura y concentración de las industrias culturales en América Latina. Buenos Aires: Prometeo Libros, 2006.

MASTRINI, Guillermo; LORETI, Damián. Políticas de comunicación: un déficit de la democracia. In: SEL, Susana (Org.). . La comunicación mediatizada: hegemonías, alternatividades, soberanías. Buenos Aires: CLACSO, 2009.

MATEOS, Concha. Venezuela bolivariana: otro paradigma teórico, otro ecosistema mediático. In: CABALLERO, Francisco Sierra; CASTRO, Rosa Elena Vallejo (Orgs.). . Derecho a la Comunicación: Procesos regulatorios y democracia en América Latina. Quito: Ciespal, 2017.

MATTA, João Paulo. Análise Competitiva da Indústria Cinematográfica Brasileira no Mercado Interno de Salas de Exibição, de 1994 a 2003. Dissertação (Mestrado) - UFBA, Salvador, 2004.

MATTELART, Armand. A globalização da comunicação. Bauru (SP): Edusc, 2002. .

MATTELART, Armand. A invenção da comunicação. Lisboa: Instituto Piaget, 1996. .

MATTELART, Armand. Comunicação-Mundo: História das idéias e das estratégias. Petrópolis (RJ): Vozes, 2001. .

MATTELART, Armand. Diversidade cultural e mundialização. São Paulo: Parábola, 2005. .

MATTELART, Armand. História da sociedade da informação. São Paulo: Loyola, 2006. .

MCCHESNEY, Robert W. Mídia global, neoliberalismo e imperialismo. In: MORAES, Dênis De (Org.). . Por uma outra comunicação: mídia, mundialização cultural e poder. Rio de Janeiro: Record, 2010.

MCKEENA, Alan. The Right to Communicate - a continuing victim of historic links to NWICO and UNESCO? In: FRAU-MEIGS, Divina et al. (Orgs.). . From NWICO to WSIS - 30 years of communication geopolitcs: actors and flows, structures and divides. Bristol (UK): Intellect, 2012.

MEDEIROS, Josué. Regressão Democrática na América Latina: do ciclo político progressista e ao ciclo político neoliberal e autoritário. Revista de Ciências Sociais v. 49, n. 1, p. 98-133, 28 fev. 2018.

MELO, José Marques De. Espaço, tempo e movimento: contribuições de Manuel Correia de Andrade para a Geografia da Comunicação. Alceu v. 10, n. 20, p. 82-99 , 2010. 
MELO, José Marques De. MacBride, a NOMIC e a participação latino-americana na concepção de teses sobre a democratização da comunicação. Logos: comunicação e universidade v. 15, n. 1 , 2008.

MENDES, Gláucia. A América Latina na perspectiva da Telesur: uma realidade a serviço do leitor/telespectador ou de interesses políticos? In: XII COLÓQUIO INTERNACIONAL SOBRE A ESCOLA LATINO-AMERICANA DE COMUNICAÇÃO, 2008, São Paulo. Anais... São Paulo: [s.n.], 2008. Disponível em: $<$ http://bit.ly/celacom>.

MENEZES, José Eugenio. Incomunicação e mídia. In: BAITELLO JR., Norval; CONTRERA, Malena Segura (Orgs.). . Os meios da incomunicação. São Paulo: Annablume, CISC, 2005.

MESA, Carlos. La libertad de expresión en el laberinto democrático de América Latina. In: SORJ, Bernardo (Org.). . Democracia y medios de comunicación: más allá del estado y el mercado. Buenos Aires: Catálogos, 2012

MÉSZÁROS, István. O poder da ideologia. São Paulo: Boitempo, 2004. 566 p. .

MISIONES. 171. . Ley VI n. 171 de Promoción Audiovisual de Misiones. , 15 maio 2014, p. 9 . Disponível em: <http://diputadosmisiones.gov.ar/web_camara/archivos/digesto/leyes/1137.pdf>.

MONJE, Daniela Inés; RIVERO, Ezequiel Alexander; ZANOTTI, Juan Martín. El Derecho a la Comunicación en Argentina amenazado: el giro a la derecha a partir de diciembre de 2015. In: CABALLERO, Francisco Sierra; CASTRO, Rosa Elena Vallejo (Orgs.). . Derecho a la Comunicación: Procesos regulatorios y democracia en América Latina. Quito: Ciespal, 2017.

MONJE, Daniela Inés; ZANOTTI, Juan Martín; RIVERO, Ezequiel Alexander. Contra-reforma na TV Pública Argentina: mudanças regressivas e reinvenção cíclica. Revista EPTIC v. 19, n. 3, p. 16 , 2017.

MONSU, Axel. Entrevista de Axel Monsu ao autor, realizada em novembro de 2016 em Posadas (Misiones, Argentina). . [S.l: s.n.]., nov. 2016

MORAES, Dênis De. Batallas por la diversidad en América Latina: avances, resistencias y dilemas. In: CABALLERO, Francisco Sierra; CASTRO, Rosa Elena Vallejo (Orgs.). . Derecho a la Comunicación: Procesos regulatorios y democracia en América Latina. Quito: Ciespal, 2017.

MORAES, Dênis De. Comunicação, hegemonia e contra-hegemonia: a contribuição teórica de Gramsci. Revista Debates v. 4, n. 1, p. 54-77, 2010 .

MORAES, Dênis De. O capital da mídia na lógica da globalização. In: MORAES, Dênis De (Org.). . Por uma outra comunicação: mídia, mundialização cultural e poder. Rio de Janeiro: Record, 2010b.

MORAES, Dênis De. Por qué la Ley de Medios de Argentina es referencia fundamental para América Latina. Disponível em: <http://www.alainet.org/es/active/61175>. Acesso em: 4 jul. 2016.

MORAES, Dênis De. Vozes abertas da América Latina: Estado, políticas públicas e democratização da comunicação. Rio de Janeiro: Mauad X, Faperj, 2011. .

MORAES, Dênis De; RAMONET, Ignacio; SERRANO, Pascual. Mídia, poder e contrapoder. São Paulo: Boitempo, 2013. .978-85-7559-318-9.

MORAGAS, Miquel De et al. El Informe MacBride, 25 años después. Contexto y contenido de un debate inacabado. Quaderns del CAC n. 21, p. 4-14, 2005.

MOREIRA, Gislene. É legal? A regulação da Comunicação Comunitária na esquerda latino-americana. RBCC V. 36, n. 1, p. 209-227, jun. 2013.

MOREIRA, Gislene. Las hormigas de macondo: Contrahegemonía y políticas de comunicación comunitaria en Argentina, Brasil y Venezuela. Tese (Doutorado em Ciências Políticas) - Flacso, México, 2011. 
MORETZSOHN, Sylvia. Jornalismo em “tempo real”: o fetiche da velocidade. Rio de Janeiro: Ed. Revan, 2002. .

MOTTA, Jorge José; MORERO, Hernán Alejandro; MOHADED, Nicolás Mariano. La interacción entre las instituciones y la producción cinematográfica y de contenidos para TV en Córdoba. Imagofagia v. 0, n. 8,25 set. 2015. Disponível em: <http://www.asaeca.org/imagofagia/index.php/imagofagia/article/view/435>. Acesso em: 14 ago. 2018.

MUNHÓZ, Eliane Regina. A rede Globo de televisão no território brasileiro através do sistema de emissoras afiliadas. Dissertação (Mestrado em Geografia Humana) - Universidade de São Paulo, São Paulo, 2008. Disponível em: <http://www.teses.usp.br/teses/disponiveis/8/8136/tde-04112009-151837/pt-br.php>.

MUROLO, Norberto Leonardo. La asombrosa excursión de Zamba. Un viaje animado por la historia en la televisión pública argentina. Chasqui. Revista Latinoamericana de Comunicación v. 0, n. 122, p. 89-95, 14 jun. 2013.

NABARRO, Wagner; SILVA, Adriana Maria Bernardes Da. Informação e território: a Agence France-Presse no Brasil. Boletim Campineiro de Geografia v. 2, n. 1, p. 37-59, 3 abr. 2012.

NATANSON, José. La nueva izquierda latinoamericana frente a los medios de comunicación: una relación compleja. , out. 2010. Disponível em: <http://rephip.unr.edu.ar/xmlui/handle/2133/2050>. Acesso em: 21 jun. 2016.

NATANSON, José. ¿Por qué? La rápida agonía de la Argentina kirchnerista y la brutal eficacia de la nueva derecha. Buenos Aires: Siglo XXI, 2018. .

NEMIROVSCI, Osvaldo. El desafío digital en la televisión argentina: comunicación, conflictos y dilemas. Sáenz Peña: Eduntref, 2011. .

NEMIROVSCI, Osvaldo. Entrevista de Osvaldo Nemirovcsi para o autor, realizada em 20/09/2016. . [S.l: s.n.]. , 20 set. 2016

NODO AUDIOVISUAL MISIONES. Acta/Informe documento de avance n. I del Nodo Audiovisual Tecnológico Misiones . [S.l.]: Polos Audiovisuales Tecnológicos. , 13 jul. 2011 a

NODO AUDIOVISUAL MISIONES. Acta/Informe documento de avance n. 2 del Nodo Audiovisual Tecnológico Misiones . [S.1.]: Polos Audiovisuales Tecnológicos. , 10 ago. 2011b

NODO AUDIOVISUAL MISIONES. Acta/Informe documento de avance n. 3 del Nodo Audiovisual Tecnológico Misiones . [S.l.]: Polos Audiovisuales Tecnológicos. , 14 set. 2011c

NORA, Pierre. O retorno do fato. In: LE GOFF, Jacques; NORA, Pierre. História: novos problemas. Rio de Janeiro: Francisco Alves, 1976.

OBERÁ EN CORTOS. Balance de las actividades realizadas - Oberá en Cortos 2007 - Festival Internacional de Cortometrajes del Noreste Argentino, por la identidad y diversidad cltural . [S.l: s.n.]. , 2007

OBERÁ EN CORTOS. Resumen - História de Entre Fronteras: espacio de encuentro y comunicación . [S.l: s.n.]. , 2009

OBSERVACOM. Argentina asigna dividendo digital de VHF a televisoras en la Ciudad de Buenos Aires .Observacom. [S.l: s.n.]. Disponível em: <http://www.observacom.org/argentina-asigna-dividendo-digital-devhf-a-televisoras-en-la-ciudad-de-buenos-aires/>. Acesso em: 28 jun. 2018. , 23 jan. 2017

OBSERVACOM. Base de datos legislativa .Observacom. [S.l: s.n.]. Disponível em: <http://www.observacom.org/bdlegislativa/>. Acesso em: 26 fev. 2018. , 31 jan. 2014 
OBSERVACOM. Regulación OTT: claves de una regulación democrática de los servicios de internet ("overthe-top") para garantizar una Internet libre y abierta y en pleno ejercicio de los derechos digitales y la libertad de expresión. . [S.l.]: Observacom. Disponível em: <http://www.observacom.org/sitio/wpcontent/uploads/2017/og/Claves-para-la-regulaci\%C3\%B3n-de-los-servicios-OTT-OBSERVACOM.pdf>. Acesso em: 12 jul. 2018. , 2018

OBSERVATÓRIO DO DIREITO À COMUNICAÇÃO. “Na terra como na mídia estamos lidando com os mesmos problemas: a questão da propriedade". Disponível em: <http://www.intervozes.org.br/direitoacomunicacao/?p=27202>. Acesso em: 27 jun. 2018.

OEA. Informe del 157 Período de Sesiones - Sede, del 2 al 16 de abril de 2016. Disponível em: <https://www.oas.org/es/cidh/prensa/docs/Informe-157.pdf >. Acesso em: 3 set. 2018a.

OEA. Sesión: 157 Periodo de Sesiones; Fecha: Friday, April 8, 2016 - Derecho a la libertad de expresión y cambios a la Ley de Servicios de Comunicación Audiovisual en Argentina. Disponível em: <https://www.oas.org/es/cidh/audiencias/TopicsList.aspx?Lang=es\&Topic=21>. Acesso em: 3 fev. 2018b.

OTTAVIANO, Cynthia. Resolución $N^{\circ}$ 21/2016 . [S.l.]: Defensoría del Público de Servicios de Comunicación Audiovisual. Disponível em: <http://archivo.defensadelpublico.gob.ar/es/resolucion-ndeg-212016>. Acesso em: 2 set. 2018. , 18 fev. 2016

PAKAPAKA. Canal do Pakapaka no Youtube. Disponível em: <https://www.youtube.com/channel/UCVVNYxncuD4EfHpKDIPIYcQ>. Acesso em: 10 dez. $2015 \mathrm{a}$.

PAKAPAKA. Institucional. Disponível em: <http://www.pakapaka.gob.ar/agenda/125995>. Acesso em: 21 jul. 2015b.

PALMA, Dante. Quinto poder: el ocaso del periodismo. Buenos Aires: Planeta, 2014. .

PALMER, Michael. NWICO: Reuters' Gerald Long versus UNESCO's Seán MacBride. In: FRAU-MEIGS, Divina et al. (Orgs.). . From NWICO to WSIS - 30 years of communication geopolitcs: actors and flows, structures and divides. Bristol (UK): Intellect, 2012.

PARSERISAS, Derlis Daniela. Los bancos como actores del circuito superior. Concentración del capital y expansión territorial de las redes bancarias en Buenos Aires. In: SILVEIRA, María Laura (Org.). . Circuitos de la economía urbana: Ensayos sobre Buenos Aires y São Paulo. Buenos Aires: Café de las Ciudades, 2016.

PASTI, André. A internalização da categoria informação no pensamento geográfico: algumas considerações. In: XXXVIII CONGRESSO BRASILEIRO DE CIÊNCIAS DA COMUNICAÇÃO, 2015, Rio de Janeiro.

Anais... Rio de Janeiro: Intercom, 2015.

PASTI, André. Notícias, informação e território : as agências transnacionais de notícias e a circulação de informações no território brasileiro. Dissertação de mestrado - 2013a. Disponível em: <http://www.bibliotecadigital.unicamp.br/document/?code=000914214\&opt=4>. Acesso em: 23 fev. 2016.

PASTI, André. Transformações e permanências na circulação de notícias na América Latina: contribuições ao debate. In: XXVI CONGRESSO BRASILEIRO DE CIÊNCIAS DA COMUNICAÇÃO, 2013b, Manaus (AM). Anais... Manaus (AM): Intercom, 2013. p.15.

PAT. Informe - Composición de la red federal de nodos - sep./2012 - Programa Polos Audiovisuales TecnológiCos . [S.l: s.n.]. , 2012

PAT. Programa Polos Audiovisuales Tecnologicos - Experiencia de Produccion Audiovisual - Informe interno. [S.l.]: TDA. , 2015

PATERSON, Chris. News Agency Dominance in International News on the Internet. Papers in International and Global Communication n. 1/6 , maio 2006. 
PAULONI, Silvina et al. Entender los contenidos educativos en la televisión pública. Configuración del nuevo escenario mediático. Actas de Periodismo y Comunicación v. 3, n. 1, p. $12,2017$.

PÁZ REBOLLO, María Antonia. Las agencias de noticias y la comunicación de masas. In: GÓMEZ MOMPART, Josep L.; MARÍN OTTO, Enric. Historia del Periodismo Universal. Madrid: Editorial Síntesis, 1999.

PEIRANO, Fernando. Un análisis de los cambios en la política para favorecer la incorporación de TIC en Argentina desde la perspectiva de los procesos empresariales. In: ROVIRA, Sebastián; STUMPO, Giovanni (Orgs.). . Entre mitos y realidades. TIC, políticas públicas y desarrollo productivo en América Latina. Santiago de Chile: CIESPAL, 2013.

PEREIRA, Evelyn. A empresa e o lugar na globalização: a "Responsabilidade social empresarial" no território brasileiro. Dissertação (Mestrado em Geografia Humana) - FFLCH/USP, São Paulo, 2007.

PEREIRA, Evelyn. Território, informação e cultura: algumas considerações. In: XII ENCUENTRO DE GEÓGRAFOS DE AMÉRICA LATINA, 2009, Montevidéu. Anais... Montevidéu: [s.n.], 2009. p.9.

PERUZZO, Cicilia Maria Krohling. Conceitos de comunicação popular, alternativa e comunitária revisitados e as reelaborações no setor. In: SAINTOUT, Florencia; VARELA, Andre (Orgs.). . Voces abiertas. Comunicación, política y ciudadanía en América Latina. Buenos Aires: CLACSO, 2015. . Acesso em: 4 set. 2018.

PERUZZO, Cicilia Maria Krohling. Revisitando os Conceitos de Comunicação Popular, Alternativa e Comunitária. In: XXIX CONGRESSO BRASILEIRO DE CIÊNCIAS DA COMUNICAÇÃO, 2006, Brasília. Anais... Brasília: UnB, 2006.

PICCONE, Néstor. La inconclusa Ley de Medios: la historia menos contada. Buenos Aires: Continente, 2015.

PIERNES, Guillermo. Comunicação e desintegração na América Latina. Brasília: Editoria da UnB, 1990. .

PINTO, Pâmela Araújo. Brasil e suas mídias regionais: estudos sobre as regiões Norte e Sul. Rio de Janeiro: Multifoco, 2017. .

PIWOWARSKI, Eva. Entrevista de Eva Piwowarski ao autor, realizada em setembro de 2016 em Buenos Aires. . [S.l: s.n.]. , set. 2016

POGGIESE, Héctor. Escenarios del presente y del futuro en la gestión democrática de las ciudades: metodologías y modelos decisionales alternativos. In: POGGIESE, Héctor; COHEN, Tamara Tania (Orgs.). . Otro desarollo urbano: ciudad incluyente, justicia social y gestión democrática. Buenos Aires: CLACSO, 2009.

POGGIESE, Héctor. Planificación participativa y gestión asociada (PPGA): Metodologías. Buenos Aires: Espacio Editorial, 2011. .

POGGIESE, Héctor; PIWOWARSKI, Eva. Territorializar la batalla cultural. Página/12 19 out. 2016 Disponível em: <http://www.paginal2.com.ar/diario/laventana/26-312099-2016-10-19.html>. Acesso em: 20 out. 2016La ventana.

POHLE, Julia. "Going Digital": A historical perspective on early international cooperation in informatics. In: FRAU-MEIGS, Divina et al. (Orgs.). . From NWICO to WSIS - 30 years of communication geopolitcs: actors and flows, structures and divides. Bristol (UK): Intellect, 2012.

POOL, Ithiel de Sola. Technologies of Freedom. [S.1.]: Belknap Press of Harvard University Press, 1983. . Acesso em: 12 jul. 2018. .978-0-674-87233-2.

POOL, Ithiel de Sola. Tecnologías sin fronteras: de las telecomunicaciones en la época de la globalización. EPUB 3 ed. [S.1.]: Fondo de Cultura Económica, 2017. 430 p. .978-607-16-5116-7. 
PORTALES, Diego. Comunicación limitación o identidad? Respuestas a la crisis. Nueva Sociedad v. 71, p. 57$58,1984$.

POSSEBON, Samuel. Grupo da UIT aprova recomendações relacionadas a serviços OTT. TELETIME News , 13 abr. 2018. Disponível em: <http://teletime.com.br/13/04/2018/grupo-da-uit-aprova-recomendacoes-relacionadas-a-servicos-ott/>. Acesso em: 12 jul. 2018.

POSTOLSKI, Glenn. Artilugios, viabilidad y voluntad en torno a la aplicación de la Ley de Medios. In: DANTAS, MARCOS (Org.). . Avances en los procesos de democratización de la comunicación en América Latina. Buenos Aires: CLACSO, 2013.

POSTOLSKI, Glenn; MARINO, Santiago. Relaciones peligrosas: los medios y la dictadura, entre el control, la censura y los negocios. In: MASTRINI, Guillermo (Org.). . Mucho ruido, pocas leyes: economia y políticas de comunicación en la Argentina (1920-2007). Buenos Aires: La Cruija, 2009.

PWC. Perspectives from the Global Entertainment \& Media Outlook 2018-2022: Trending now: convergence, connections and trust . [S.l.]: PWC. Disponível em: <https://www.pwc.com/gx/en/entertainmentmedia/outlook/perspectives-from-the-global-entertainment-and-media-outlook-2018-2022.pdf>. , 2018

QUINTAR, Aída; GONZALEZ, Leandro; BARNES, Carolina. Producción audiovisual comunitaria: una democratización del relato. Question v. 1, 2014. Disponível em: <http://sedici.unlp.edu.ar/handle/10915/37989>. Acesso em: 4 ago. 2016.

QUINTERO, Silvina. Geografías regionales en la Argentina. Imagen y valorización del territorio durante la primera mitad del siglo XX. Scripta Nova v. VI, n. 127, 2002. Disponível em: <http://www.ub.edu/geocrit/sn/sn-127.htm>. Acesso em: 11 ago. 2018.

RAFFESTIN, Claude. Por uma geografia do Poder. São Paulo: Ática, 1993. .

RAMONET, Ignacio. A tirania da comunicação. 5. ed. Petrópolis (RJ): Vozes, 2010. .

RAMONET, Ignacio. Meios de comunicação: um poder a serviço de interesses privados. In: MORAES, Dênis De (Org.). . Mídia, poder e contrapoder. São Paulo: Boitempo, 2013. 978-85-7559-318-9.

RAMOS, María Gabriela; FRANCISCOVIC, Karina. La economía social y la generación de contenidos audiovisuales en Santa Cruz. In: VI ENCUENTRO PANAMERICANO DE COMUNICACIÓN, 2013, Córdoba. Anais... Córdoba: UNC, 2013. Disponível em: <http://www.publicacioncompanam2013.eci.unc.edu.ar/files/companam/ponencias/Escenarios\%2odigitales/-Unlicensed-EscenariosDigitales.-Ramos-2.pdf>. Acesso em: 27 jul. 2018.

REBELATTO, Francieli; FONSECA, Eduardo Dias. Fórum Entre Fronteiras: uma experiência de produção cinematográfica transnacional no Mercosul. Revista SURES v. 1, n. 5 , 7 fev. 2015. Disponível em: <https://revistas.unila.edu.br/sures/article/view/284>. Acesso em: 28 jul. 2018.

RED NACIONAL DE MEDIOS ALTERNATIVOS. A 3 Años de la sanción de la nueva Ley de Medios. In: LEÓN, Osvaldo (Org.). . Democratizar la palabra: movimientos convergentes en comunicación. Quito: ALAI, 2013.

RED NACIONAL DE MEDIOS ALTERNATIVOS. Segundo Taller Integral de Comunicación Radial: modelo para armar medios propios. Disponível em: <https://rnma.org.ar/documentos/talleres/1l80-modelo-paraarmar-medios-propios>. Acesso em: 14 jul. 2018.

REYES AGUINAGA, Hernán. ¿Regulación democrática de la comunicación en Ecuador?: complejidades y conflictos del proceso jurídico y político (2009-2016). In: CABALLERO, Francisco Sierra; CASTRO, Rosa Elena Vallejo (Orgs.). . Derecho a la Comunicación: Procesos regulatorios y democracia en América Latina. Quito: Ciespal, 2017. 
RIBEIRO, Ana Clara Torres. A natureza do poder: técnica e ação social. Interface - Comunicação, Saúde, Educação v. 4, n. 7, 2000.

RIBEIRO, Ana Clara Torres. Cultura, Ação e Planejamento. In: AMBIENS SOCIEDADE COOPERATIVA

(Org.). . Estado e lutas sociais: intervenções e disputas no território. Curitiba: Kairós, 2010.

RIBEIRO, Ana Clara Torres. Matéria e espírito: o poder (des)organizador dos meios de comunicação. In: PIQUET, Rosélia; RIBEIRO, Ana Clara Torres. Brasil, território da desigualdade: descaminhos da modernização. Rio de Janeiro: Jorge Zahar, Fundação Universitária José Bonifácio, 1991.

RIBEIRO, Ana Clara Torres. Matéria e espírito: o poder (des)organizador dos meios de comunicação. Por uma sociologia do presente: ação técnica e espaço. Rio de Janeiro: Letra Capital, 2011a. 3 V.

RIBEIRO, Ana Clara Torres. Por uma sociologia do presente: ação técnica e espaço. Rio de Janeiro: Letra Capital, 2012a. 1 v. .

RIBEIRO, Ana Clara Torres. Por uma sociologia do presente: ação técnica e espaço. Rio de Janeiro: Letra Capital, 2013a. 3 v. .

RIBEIRO, Ana Clara Torres. Por uma sociologia do presente: ação técnica e espaço. Rio de Janeiro: Letra Capital, 2013b. 4 V. .

RIBEIRO, Ana Clara Torres. Relações Sociedade-Estado: elementos do paradigma administrativo. Por uma sociologia do presente: ação técnica e espaço. Rio de Janeiro: Letra Capital, 2011b. 3 V.

RIBEIRO, Ana Clara Torres. Teorias da ação. Rio de Janeiro: Letra Capital, 2014. .

RIBEIRO, Ana Clara Torres. Territórios da sociedade, impulsos globais e pensamento analítico: por uma cartografia da ação. Revista Tamoios v. 8, n. 1, 20 set. 2012b. Disponível em: < http://www.e-publicacoes.uerj.br/index.php/tamoios/article/view/3295>. Acesso em: 1 set. 2018.

RIBEIRO, Ana Clara Torres; SILVA, Catia Antonia. Impulsos globais e espaço urbano: sobre o novo economicismo. El rostro urbano de América Latina. O rostro urbano da América Latina. Buenos Aires: CLACSO, 2004. p. 32.

RINESI, Eduardo. Entrevista de Eduardo Rinesi ao autor, realizada em janeiro de 2016 em Buenos Aires. . [S.l: s.n.]. , jan. 2016

RIVERO, Ezequiel A. Video a Demanda: ¿El futuro de los medios públicos o una batalla perdida? RevCom v. O, n. 3, p. 83-98, 7 dez. 2016.

ROACH, Colleen. The U.S. Position on the New World Information and Communication Order. Journal of Communication v. 37, n. 4, p. 36-51, 1 dez. 1987.

RODRIGUEZ, Gustavo Gonzalez. New scenarios for the Right to Communicate in Latin America. In: FRAUMEIGS, Divina et al. (Orgs.). . From NWICO to WSIS - 30 years of communication geopolitcs: actors and flows, structures and divides. Bristol (UK): Intellect, 2012.

RODRÍGUEZ, Marcelo Alejandro. Entrevista de Marcelo Alejandro Rodríguez ao autor, realizada em novembro de 2016 em Posadas (Misiones, Argentina). . [S.l: s.n.]. , nov. 2016

ROJAS, Luisa Iñiguez. Entrevista. Boletim Campineiro de Geografia v. 4, n. 1 , 2014.

ROJAS, Luisa Iñiguez. Trayectorias y transformaciones territoriales en la Cuba actual. GEOUSP: Espaço e Tempo (Online) v. 19, n. 2, p. 212-227, 2015. 
ROSSI, Diego. La radiodifusión entre 1990-1995: exacerbación del modelo privado-comercial. In: MASTRINI, Guillermo (Org.). . Mucho ruido, pocas leyes: economia y políticas de comunicación en la Argentina (1920-2007). Buenos Aires: La Cruija, 2009.

RT. RT acuerda con autoridades argentinas la continuidad de la señal en ese país. Disponível em: <https://actualidad.rt.com/actualidad/213463-argentina-television-rusia-transmision-rt>. Acesso em: 3 set. 2018.

RUMMERT, Sonia Maria. Os meios de comunicação de massa como aparelhos de hegemonia. Dissertação (Mestrado em Educação) - FGV, Rio de Janeiro, 1986. Disponível em: <https://bibliotecadigital.fgv.br/dspace/handle/10438/9109>. Acesso em: 4 set. 2018.

RUS, Guillermo Jorge. El futuro llegó: Plan Satelital Geoestacionario Argentino 2015-2035. Buenos Aires: Kaband, 2016. .

SALVIOLO, Cielo. La experiencia de Pakapaka. In: UNESCO (Org.). . Crescer Juntos para la Primera Infancia: encuentro regional de políticas integrales. Buenos Aires: Unesco, 2012. Disponível em: <http://www.unicef.org/argentina/spanish/educacion_Libro_primera_infancia.pdf>. Acesso em: 21 jul. 2016.

SAMANIEGO, Pablo. ¿Globalización o hipermercantilización del fútbol? In: CARRIÓN, Fernando; RODRÍGUEZ, María José (Orgs.). . Luchas urbanas alrededor del fútbol. Quito: 5ta Avenida Editores, 2014.

SANTANDER, Pedro. El "derecho a la comunicación”: síntoma de antagonismo y recuperación de derechos sociales en el actual ciclo político latinoamericano. In: SAINTOUT, Florencia; VARELA, Andre (Orgs.). . Voces abiertas. Comunicación, política y ciudadanía en América Latina. Buenos Aires: CLACSO, 2015. Acesso em: 4 set. 2018.

SANTANDER, Pedro. Nuevas leyes de medios en Sudamérica: enfrentando políticamente la concentración mediática. Convergencia Revista de Ciencias Sociales n. 66 , 1 set. 2014. Disponível em: <https://convergencia.uaemex.mx/article/view/1767>. Acesso em: 8 set. 2018.

SANTOS, Milton. A geografia no fim do século XX: a redescoberta e a remodelagem do planeta e os papéis de uma disciplina ameaçada. Geonordeste v. 1, n. 2, p. 1-13, 1984.

SANTOS, Milton. A natureza do espaço: técnica e tempo, razão e emoção. São Paulo: Edusp, 2006. .

SANTOS, Milton. Da política dos Estados à política das empresas. Cadernos da Escola do Legislativo v. 3, n. 6, p. 9-23, 1998.

SANTOS, Milton. Da totalidade ao lugar. São Paulo: Edusp, 2008a. .

SANTOS, Milton. Economia Espacial: críticas e alternativas. São Paulo: Edusp, 2003. .

SANTOS, Milton. O Espaço do Cidadão. São Paulo: Edusp, 2007. .

SANTOS, Milton. O retorno do território. In: SANTOS, Milton. Território: globalização e fragmentação. São Paulo: Hucitec, ANPUR, 1994.

SANTOS, Milton. O território e o saber local: algumas categorias de análise. Cadernos IPPUR n. Ano XIII, n. 2, p. 15-26, 1999.

SANTOS, Milton. O trabalho do geógrafo no terceiro mundo. São Paulo: Edusp, 2009a. .

SANTOS, Milton. Por uma economia política da cidade: o caso de São Paulo. São Paulo: Edusp, 2009 b. .

SANTOS, Milton. Por uma geografia nova: da crítica da geografia a uma geografia crítica. São Paulo: Edusp, 2004. 285 p. .85-314-0715-X. 
SANTOS, Milton. Por uma outra globalização: do pensamento único à consciência universal. Rio de Janeiro: Editora Record, 2000. .

SANTOS, Milton. Sociedade e Espaço: a formação socioespacial como teoria e como método. Antipode v. 9 , n. 1 , fev. 1977.

SANTOS, Milton. Técnica, Espaço, Tempo: globalização e o meio técnico-científico informacional. São Paulo: Edusp, 2008b. .

SANTOS, Milton; SILVEIRA, María Laura. O Brasil: território e sociedade no início do século XXI. Rio de Janeiro: Editora Record, 2001. .

SARAMAGO, José. A quoi sert la communication ? Disponível em: <https://www.mondediplomatique.fr/1998/12/SARAMAGO/4209>. Acesso em: 27 dez. 2017.

SARAMAGO, José. Ensaio sobre a cegueira. São Paulo: Companhia das Letras, 2009. .

SARTRE, Jean-Paul. Crítica da razão dialética: precedido por Questões de método. Rio de Janeiro: DP\&A, 2002. .

SCHILLER, Dan. Digital capitalism: networking the global market system. Cambridge, MA: MIT Press, 1999. 294 p. .

SCHILLER, Dan. How to Think About Information. In: MOSCO, V; WASKO, J (Ed.). . The political economy of information: studies in communication and society. Madison: The University of Wisconsin Press, 1988.

SEGRERA, Francisco López. América Latina: crisis del posneoliberalismo y ascenso de la nueva derecha. Buenos Aires: CLACSO, 2016. .

SEGURA, María Soledad. Democratizar las Comunicaciones en Argentina: la Norma y las Luchas. Revista Arena V. 1, n. 1, 2010.

SEGURA, María Soledad. La sociedad civil y la democratización de las comunicaciones en la Argentina. La experiencia de la Coalición por una Radiodifusión Democrática. Argumentos. Revista de crítica social n. $13,2011$.

SEGURA, María Soledad et al. Los públicos de medios comunitarios, populares y alternativos en América Latina. El caso argentino. Commons: revista de comunicación y ciudadanía digital v. 7, n. 1, p. 5-45 , 2018.

SEGURA, María Soledad. Medios no lucrativos de Argentina. De la lucha por la legalidad al debate sobre la sostenibilidad. In: SEGURA, María Soledad; WECKESSER, Cintia (Orgs.). . Los medios sin fines de lucro entre la Ley Audiovisual y los decretos: estrategias, desafíos y debates en el escenario 2009-2015. Córdoba: Editorial de la UNC, 2016. Disponível em: < http://democratizarcomunicacion.eci.unc.edu.ar/files/VersionPreliminar-Abrili5.pdf>. Acesso em: 17 ago. 2018.

SEL, Susana. Comunicación alternativa y políticas públicas en el combate latinoamericano. La comunicación mediatizada: hegemonías, alternatividades, soberanías. Buenos Aires: CLACSO, 2009.

SEL, Susana. La democratización comunicacional en Argentina: avances en políticas públicas y obstáculos económicos, políticos y culturales. In: DANTAS, MARCOS (Org.). . Avances en los procesos de democratización de la comunicación en América Latina. Buenos Aires: CLACSO, 2013.

SERPA, Ângelo. Lugar e mídia. São Paulo: Contexto, 2011. .

SERRANO, Pascual. Desinformación: como los medios ocultan el mundo. Havana: Editorial José Martí, 2011. . 
SERRANO, Pascual. Outro jornalismo possível na internet. In: MORAES, Dênis De (Org.). . Mídia, poder e contrapoder. São Paulo: Boitempo, 2013. 978-85-7559-318-9.

SERVETTI, Carla. Programa Futbol para Todos e interés público, ¿hacia una democratización de las imágenes televisivas del fútbol? In: VII JORNADAS DE JÓVENES INVESTIGADORES, 2013, Buenos Aires. Anais... Buenos Aires: UBA, 2013. Disponível em: <http://www.aacademica.org/000-076/288>. Acesso em: 21 jun. 2016.

SILVA, Adriana Bernardes. As grandes empresas de consultoria, a produção de informações e os novos círculos de cooperação no território brasileiro. In: X ENCONTRO DE GEÓGRAFOS DA AMÉRICA LATINA, 2005, São Paulo. Anais... São Paulo: USP, 2005. Disponível em: <http://observatoriogeograficoamericalatina.org.mx/egalı/Geografiasocioeconomica/Geografiaindustrial/18.pdf>. Acesso em: 2 set. 2018.

SILVA, Adriana Bernardes. Círculos de informações e novas dinâmicas do território brasileiro. In: XVI ENCONTRO NACIONAL DE GEÓGRAFOS, 2010, Porto Alegre. Anais... Porto Alegre: AGB, 2010.

SILVA, Adriana Bernardes. Círculos de informações, urbanização e usos do território. Revista da ANPEGE v. 8, n. $10,2012$.

SILVA NETO, Manoel Lemes. Território usado/praticado como categoria central do planejamento urbano e regional. In: XVII ENANPUR, 2017, São Paulo. Anais... São Paulo: ANPUR, 2017. Disponível em: <http://anpur.org.br/xviienanpur/principal/publicacoes/XVII.ENANPUR_Anais/SL_Sessoes_Livres/SL\%2018.pdf>. Acesso em: 8 jan. 2018.

SILVEIRA, María Laura. Argentina: do desencantamento da modernidade à força dos lugares. In: SILVEIRA, María Laura (Org.). . Continente em chamas: globalização e território na América Latina. Rio de Janeiro: Civilização Brasileira, 2005.

SILVEIRA, María Laura. Buenos Aires en clave de modernidad y pobreza. In: SILVEIRA, María Laura (Org.). Circuitos de la economía urbana: Ensayos sobre Buenos Aires y São Paulo. Buenos Aires: Café de las Ciudades, 2016.

SILVEIRA, María Laura. Concretude territorial, regulação e densidade normativa. Experimental v. 1, n. 2, p. 35-45, mar. 1997.

SILVEIRA, María Laura. Por um conteúdo da reflexão epistemológica da geografia. In: SOUZA, Álvaro José De (Org.). . Paisagem território região: em busca de identidade. Cascavel (PR): Ediunioeste, 2000.

SILVEIRA, María Laura. Por uma teoria do espaço latino-americano. In: LEMOS, Amalia Inés Geraiges De; SILVEIRA, María Laura; ARROYO, Mónica (Orgs.). . Questões territoriais na América Latina. Buenos Aires: CLACSO, 2006.

SILVEIRA, María Laura. Um país, uma região: fim de século e modernidades na Argentina. São Paulo: LABOPLAN/FAPESP, 1999a. .

SILVEIRA, María Laura. Uma situação geográfica: do método à metodologia. Revista Território v. IV, n. 6 , 1999b. Disponível em: <http://www.revistaterritorio.com.br/pdf/o6_3_silveira.pdf>. Acesso em: 22 jul. 2018.

SILVEIRAS, Raphael. Consultas públicas para o Marco Civil da Internet e Reforma da Lei de Direito Autoral : a relação entre direito, Internet e Estado na contemporaneidade. Dissertação (Mestrado) IFCH/UNICAMP, Campinas, 2014. Disponível em: <http://www.repositorio.unicamp.br/handle/REPOSIP/280225 >. Acesso em: 26 fev. 2018.

SOMMA NETO, João; DIAS, Eduardo Covalesky. 6-7-8 x Periodismo Para Todos: o antagonismo televisionado da Lei de Meios Audiovisuais da Argentina. E-Compós | Revista da Associação Nacional dos Programas de Pós-Graduação em Comunicação v. 19 , 2016. Disponível em: <http://www.e-compos.org.br/ecompos/article/view/1224/>. Acesso em: 19 dez. 2018. 
SOUSA SANTOS, Boaventura. La caída del angelus novus: ensayos para una nueva teoría social y una nueva práctica política. Bogotá: ILSA, 2003. . Acesso em: 6 set. 2018. .

STEDA, Melissa. Políticas do Estado e políticas das empresas: um estudo sobre a internet de banda larga no Brasil. Trabalho de Conclusão de Curso (Geografia) - UNICAMP, Campinas (SP), 2012. 81 p. Disponível em: <http://www.bibliotecadigital.unicamp.br/document/?code=000901174>.

STURZA, Eliana Rosa. Fronteiras e práticas lingüísticas: um olhar sobre o portunhol. Revista Internacional de Lingüística Iberoamericana v. 2, n. 1 (3), p. 151-160 , 2004.

SUÁREZ, Luis. Mass communications and the major challenges. In: UNESCO (Org.). . Media and democracy in Latin America and the Caribbean. Paris: Unesco, 1996. Disponível em: <http://unesdoc.unesco.org/images/0010/001039/103934Eb.pdf>. Acesso em: 19 jul. 2016.

TDA. Banco Audiovisual de Contenidos Universales Argentino (BACUA) . [S.l: s.n.]. Disponível em: <http://catalogo.bacua.gob.ar/>. Acesso em: 1 dez. 2015a. , 2015

TDA. Listado de señales disponibles en TDA - Televisión Digital Abierta . [S.l.]: Ministerio de Planificación Federal, Inversión Pública y Servicios. Disponível em: <http://www.tda.gob.ar:80/programacion/salida.pdf>. Acesso em: 1 dez. 2015b. , 2015

TEIXEIRA, Sérgio Henrique de Oliveira. Círculos de informações e usos do território : grandes empresas de consultoria e a gestão da privatização no Brasil. , 2013. Disponível em: <http://repositorio.unicamp.br/jspui/handle/REPOSIP/287401>. Acesso em: 2 set. 2018.

TÉLAM. Un informe revela el pacto entre Videla, Clarín y La Nación para quedarse con Papel Prensa. Disponível em: <http://www.telam.com.ar/notas/201504/102363-papel-prensa-pacto-dictadura-clarin-la-nacion.html>. Acesso em: 17 jun. 2016.

TELECO. Uso de Frequências: O espectro de radiofrequências. Disponível em: <http://www.teleco.com.br/tutoriais/tutorialfreq/pagina_l.asp>. Acesso em: 24 fev. 2018.

TELEFE. Viacom compra Telefe a Telefónica por US\$345 millones de dólares. Disponível em: <http://telefe.com/telefe/novedades/viacom-compra-telefe-a-telefonica-por-us-345-millones-de-dolares/>. Acesso em: 3 set. 2018.

TELESÍNTESE. Proposta brasileira para definição de OTTs é adotada internacionalmente. TeleSíntese , 10 maio 2018. Disponível em: <http://www.telesintese.com.br/proposta-brasileira-para-definicao-de-otts-eadotada-internacionalmente/>. Acesso em: 12 jul. 2018.

TELESUR. La primera marcha contra el gobierno Macrista. Disponível em: < https://www.telesurtv.net/imreporter/La-primer-marcha-contra-el-gobierno-Macrista--20151215-0015.html>. Acesso em: 3 set. 2018.

THRIFT, Nigel. Torsten Hägerstrand and social theory. Progress in Human Geography n. 29, p. 337-340 , jun. 2005.

TOZI, Fábio. As privatizações e a viabilização do territorio com recurso. Dissertação (Mestrado em Geografia) - UNICAMP, Campinas (SP), 2005. Disponível em: <http://www.bibliotecadigital.unicamp.br/document/?code $=$ vtlso00348436 $>$.

TRIVIÑO, Alejandra Páez. Distribución online. Televisiones convergentes, intereses divergentes. In: MARINO, Santiago (Org.). . El audiovisual ampliado: políticas públicas, innovaciones del mercado y tensiones regulatorias en la industria de la televisión argentina frente a la convergencia. Buenos Aires: Ediciones Universidad del Salvador, 2016.

UIT. Spectrum Allocation Issues. Disponível em: <https://www.itu.int/osg/spu/imt-200o/spectrum.html>. Acesso em: 22 jun. 2018. 
UNESCO. Análisis del desarrollo mediático en Bolivia: basado en los Indicadores de Desarrollo Mediático de la Unesco . [S.l.]: Unesco. Disponível em: <http://unesdoc.unesco.org/images/0024/002468/246822s.pdf>. Acesso em: 26 fev. 2018. , 2016

UNESCO. "MacBride Report" - Many Voices, One World. Communication and Society Today and Tomorrow. Towards a new more just and more efficient world information and communication order. Relatório da Comissão Internacional para o Estudo dos Problemas de Comunicação Paris: Unesco, 1980.

UNESCO. Reshaping cultural policies: a decade promoting the diversity of cultural expressions for development: 2005 Convention global report. Paris: United Nations Educational, 2015. 235 p. .978-92-3100136-9.

URUGUAY. Ley 18.232 - Radiodifusión Comunitaria . [S.l: s.n.]. Disponível em: <https://legislativo.parlamento.gub.uy/temporales/leytemp1884863.htm>. Acesso em: 6 set. 2016. , 9 jan. 2008

URUGUAY. Ley 19.307 - Ley de Servicios de Comunicación Audiovisual . [S.l: s.n.]. Disponível em: <https://www.impo.com.uy/bases/leyes/19307-2014>. Acesso em: 5 jul. 2016. , 2014

VALENTE, Jonas Chagas Lúcio. TV pública no Brasil : a criação da TV Brasil e sua inserção no modo de regulação setorial da televisão brasileira. Dissertação / Dissertation. Disponível em: <http://repositorio.unb.br/handle/10482/5468>. Acesso em: 21 jul. 2016.

VALVERDE, Rodrigo. A indústria cultural como objeto de pesquisa geográfica. Revista do Departamento de Geografia - USP v. $29,2015$.

VAN CUILENBURG, Jan; MCQUAIL, Denis. Media Policy Paradigm Shifts: Towards a New Communications Policy Paradigm. European Journal of Communication v. 18, n. 2, p. 181-207, jun. 2003.

VAPNARSKY, C. A. Primacia y macrocefalia en la Argentina: la transformacion del sistema de asentamiento humano desde 1950. Desarrollo económico v. 35, n. 138, p. 227-254 , 1995.

VÁSQUEZ, Bernardo; CAYÓN, David. Fútbol para Todos: la política de los goles. Buenos Aires: Sudamericana, 2014. .

VEDEL, Thierry. Les politiques des autoroutes de l'information dans les pays industrialisés : une analyse comparative. Réseaux. Communication - Technologie - Société v. 14, n. 78, p. 11-28 , 1996.

VELÁZQUEZ, Guillermo; GÓMEZ LENDE, Sebastián. Medio técnico-científico-informacional y equipamiento tecnológico. Modernización y fragmentación socio-territorial en la Argentina de los noventa. Cuadernos de Geografía : Revista Colombiana de Geografía v. 14 , 1 out. 2005.

VENEZUELA, República Bolivariana De. Ley de Responsabilidad Social en Radio, Televisión y Medios Electrónicos . [S.l: s.n.]. Disponível em: <http://bit.ly/leyresorte>. Acesso em: 4 abr. 2014. , 2011

VERBITSKY, Horacio. Rodolfo Walsh y La prensa clandestina. 1976-1978. Buenos Aires: Urraca, 1985,. Buenos Aires: Ediciones de la Urraca, 1985.

VICENTE, María Álvarez. Entrevista de María Álvarez Vicente ao autor, realizada em setembro de 2016 em Buenos Aires. . [S.l: s.n.]. , set. 2016

VINELLI, Natalia (Org.). Comunicación y televisión popular: escenarios actuales, problemas y potencialidades. Buenos Aires: Cooperativa Gráfica El Río Suena, 2011a. .

VINELLI, Natalia. De la posibilidad de existencia a las condiciones de funcionamiento aceptadas. Las dificultades del encuadramiento de la alternatividad dentro de la categoría sin fines de lucro. AVATARES de la Comunicación y la Cultura n. 6 , 2013. Disponível em: <http://ppct.caicyt.gov.ar/index.php/avatares/article/viewFile/2897/pdf>. Acesso em: 17 ago. 2018. 
VINELLI, Natalia. Entrevista de Natalia Vinelli ao autor, em setembro de 2017 em Buenos Aires. . [S.l: s.n.]. , set. $2017 a$

VINELLI, Natalia. La television desde abajo: historia, alternatividad y periodismo de contrainformación. Buenos Aires: Editorial Cooperativa El Río Suena, El Topo Blindado, 2014. .

VINELLI, Natalia. Medios alternativos, populares y comunitarios: desigualdades, fomento e incorporación de tecnologías. In: BELTRÁN, Ricardo; BECERRA, Martín (Orgs.). . Sin fines de lucro, con tecnologías Y organización. Buenos Aires: Ricardo Beltrán, 2017b. Disponível em: <http://www.rbeltran.com.ar/ceseptic/libros/sinFinesfinal.pdf>. Acesso em: 31 jan. 2018. 978-987-42-5656-0.

VINELLI, Natalia. Por una televisión alternativa y masiva. In: VINELLI, Natalia (Org.). . Comunicación y televisión popular: escenarios actuales, problemas y potencialidades. Buenos Aires: Cooperativa Gráfica El Río Suena, 2011b.

WAISBORD, Silvio; SEGURA, María Soledad. Media Movements: Civil Society and Media Policy Reform in Latin America. London: Zed Books, 2016. .

WALTZ, Igor. A Ley de Medios argentina e o discurso antirregulação em jornais brasileiros. In: X POSCOM SEMINÁRIO DOS ALUNOS DE PÓS-GRADUAÇÃO EM COMUNICAÇÃO SOCIAL DA PUC-RIO, 2013, Rio de Janeiro. Anais... Rio de Janeiro: PUC-Rio, 2013. Disponível em: <https://is.gd/uBctEy>.

WARF, Barney. Geographies of global Internet censorship. GeoJournal v. 76, n. 1, p. 1-23, 1 fev. 2011.

WARF, Barney. Global Geographies of the Internet Google-Books-ID: HGHwMXVXzD8C. [S.l.]: Springer Science \& Business Media, 2012. 170 p. .

WARF, Barney. Telecommunications and the Changing Geographies of Knowledge Transmission in the Late 20th Century. Urban Studies v. 32, n. 2, p. 361-378, 1 mar. 1995.

WU, Tim. Impérios da comunicação: Do telefone à internet, da AT\&T ao Google. [S.1.]: Zahar, 2012. .

YAMAMOTO, Eduardo Yuji. A natureza da comunicação popular e comunitária. In: XXX CONGRESSO BRASILEIRO DE CIÊNCIAS DA COMUNICAÇÃO, 2007, Santos. Anais... Santos: Intercom, 2007.

ZAMBONI, Rubén Aníbal et al. Los Medios Audiovisuales en Misiones y su aporte Educativo. Desde lo analógico a lo digital . [S.l.]: UNAM. Disponível em: <http://argos.fhycs.unam.edu.ar/handle/123456789/216>. Acesso em: 29 jul. 2018. , 16 abr. 2014

ZAMBONI, Rubén Aníbal. Reseña de la producción audiovisual educativa en el SiPTeD. In: JORNADAS DE INVESTIGADORES 2015 DE FHYCS - UNAM, 2015, Posadas. Anais... Posadas: UNAM, 2015. p.21. 24690678. .

ZANOTTI, Ana. Entrevista Ana Zanotti ao autor, realizada em novembro de 2016 em Posadas (Misiones, Argentina). . [S.l: s.n.]. , nov. 2016

ZAROWSKY, Mariano. El “documental piquetero": en torno a las modalidades de representación e intervención audiovisual. In: VINELLI, Natalia; ESPERÓN, Carlos Rodríguez (Orgs.). . Contrainformación: medios alternatvios para la acción política. Buenos Aires: Continente, 2004.

ZUSMAN, Perla. La técnica y la definición de fronteras. Revista de Geografía Norte Grande n. 66 , 2017. 